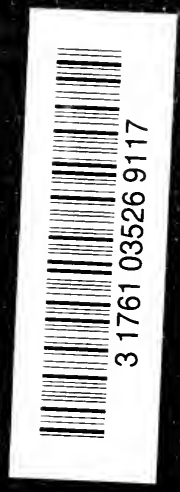




Itarold Glementson: biff bourage.

Bay View Road. Port St Mary. Sole of man. 

HISTORY OF STEAM NAVIGATION. 

Digitized by the Internet Archive in 2007 with funding from Microsoft Corporation 


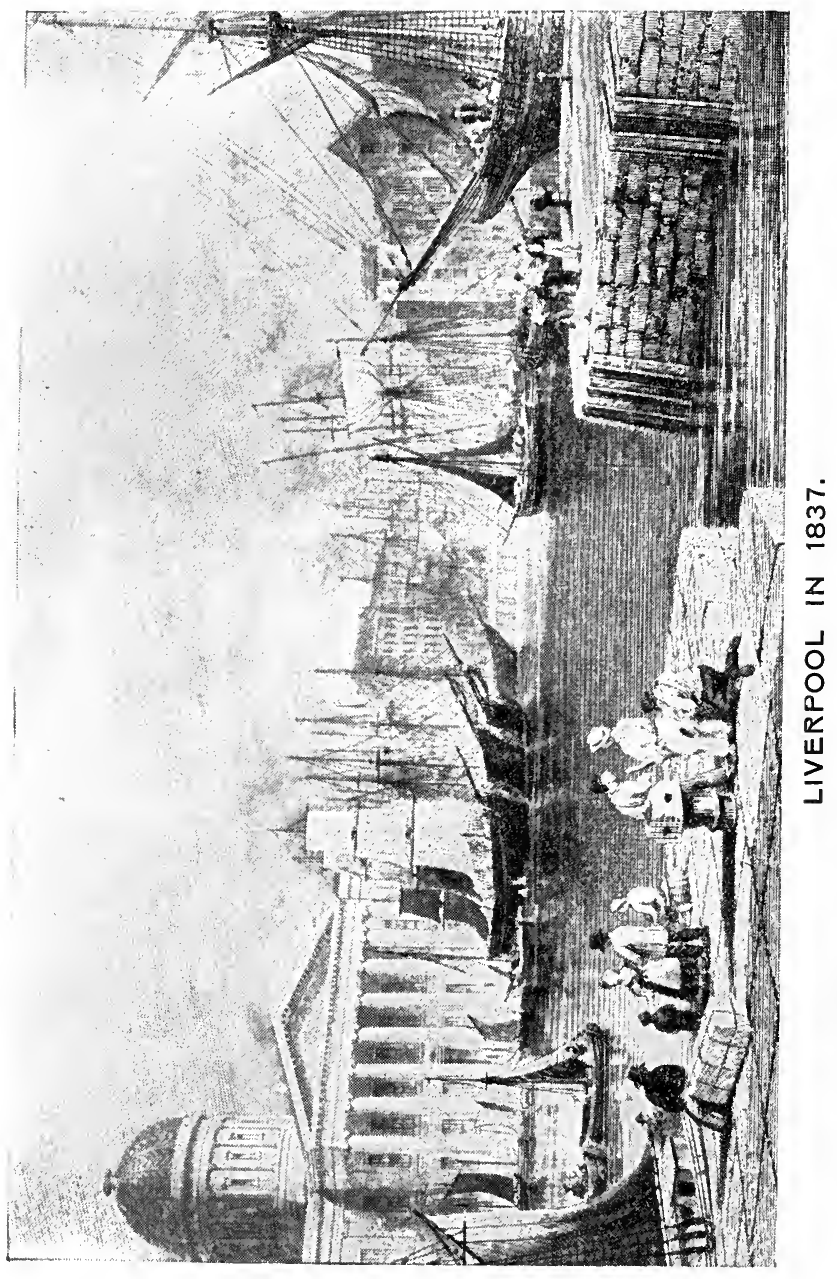


THE

\title{
HISTORY
}

$\mathrm{OF}$

\section{STEAM NAVIGATION.}

\author{
BY \\ JOHN KENNEDY.
}

WITH NUMEROUS ILLUSTRATIONS.

\section{PUBLISHED BY}

CHARLES BIRCHALL, LIMITED,

7 \& 9, VICTORIA STREET, LIVERPOOL.

1903. 


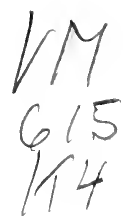

i. TINLING IND CO.,

PRINTERS,

VICTORA STHEET, LIVHPOOL. 


\section{PREFACE.}

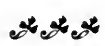

Tre historieal information eontained in this volume has been in a large measure collected from the Press of the period, and chiefly from the Times, Liverpool Merrmy, Glasgou Herald, and Chambers' Jommal. Lindsay's "Mrrchant Shipping," a most admirable work, has also been consulted, as well as other works of a similar nature. The name of the authority quoted has been given in most cases, but, where I have been unable to do so, I trust this general acknowledgment will suffice.

Some of the chapters in Part II. were contributed in 1901 to the Journal of Commure, as part of a series of articles on "Historical Steamship Companies." Chapter XXII. in Part I. was published in the May number (1903) of the Wide World Mayazine, under the title of "The Strange Case of the lerreT."

I take this opportunity of thanking the 1)irectors, Managers, Agents, and other officials of the various Steamship Companies referred to, by all of whom, and at all times, I have been treated with the utmost courtesy. I desire also to express my appreeiation of the uniform kindness and assistance received from the Librarians of the Bootle, Glasgow, and Liverpool Libraries in placing at my disposal publications, some of which were printed nearly a hundred years ago.

\section{JOHN KENNEIST.}

Liver poot, 20th November, 1903. 



\section{O N T E N T S.}

\section{PART I.}

CHAPTER I.-Inventors and Alleged Inventors prior to 1807.-De Garay (1543)-Papin (1690)—Savory, Neweomen (1705)—Hulls (1736)—A bbé Arnal and the Marquis de Joufiroy (1781)—Fiteh (1783)-Miller and Taylor (1788)-Symington (1801)-The CHaRLotTe Dundas (1803)Bell (1803)

CHAPTER II.-Fulton (1807)-The Clermont (1807), the first passenger steamboat in the world-Narrative of her first voyage-Steam Navigation in Canadian waters-First steamers on the St. Lawrenee-The Accommodation (1809)-Swiftsure, CAR of ComMERCE (1813)-QUEBEC (1817)

(HAPTER III.-1812 to 1815-Steamboats on the Clyde-The CoмET, Industry and Argyle-First Irish Steamer, City of Cork (1815) -Ireland's honourable position in the annals of steam navigation -First London Steampackets, Marjory, Defiance and Thames...

CHAPTER IV.-The year 1815-Arrival of the first steampacket on the Mersey-Narrative of the voyage of the Thames from Glasgow to London

CHAPTER V.-1816 to 1818-London packets, the Defiance, Majestic, REGEN:-Loss of the REgENT (1817)-Liverpool and Eastham Packet, Princess Charlotte (1816)-Liverpool and Tranmere Packets Regulator, Etxa (1817)-Parkgate and Bagillt Packet, Ancient Briton (1817)-Loss of the Rfgulator (1818)-First Spanish Steamer, Royal Ferdinand (1817)-Siberian Steamboats (1817)— David Napier-The Rob Roy, Hibernia (1816) $\quad \ldots \quad \ldots \quad \ldots 23$

CHAPTER VI.-Early Clyde Steampaekets-The first steamer to cross the English Channel, Caledonia-First steamer on the Rhine (1816)-Season contract tickets issued (1816)-Stranding of the Rothesay Castle (1816)-Steamship passengers' fares on the Clyde in 1818-Dumbarton Castle steams round North of Scotland (1819) 
CHAP'TER VII.-1819 to 1821-The first steamer to eross the Atlantic, the SAvANNAH-Arrival at Liverpool of the first eross-ehannel steamer, WATERLoo-The Robert BRUCE-Curious accident to the Morning Star-The Triton-Conde de Patmella-SnakeCattle ventilators suggested-The TourisT-London and Leith steamers

CHAPTER VIII.-The St. George Steampacket Co.-Steam Yacht Hero -Liverpool steampackets highly commended in Parliamentary Report-Aaron MANBy, first iron steamer-First steamer Hull to Continent-City of Dublin Steampacket Co.-Dublin and Liverpool Steam Navigation Co.-H.M.S. Lightring-General Steam Navigation Co.-Belfast Steampaeket Co.-Keen eompetition on the Glasgow and Belfast station-Advertising extraordinaryMessrs. G. \& J. Burns commenee business 1825-Messrs. MacBrayne's Highland Service-Competition in the Liverpool and Dublin trade-First steamer London to Hamburg-First steamer England to India ; rapid increase of steampackets-Hostile meeting at Swansea-The ERs-Admiralty Mail Steampacket Service between Liverpool and Kingstown established-City of Dublin Steampacket Co. establish a service between the United Kingdom and Bordeaux

CHAP'TER IX.-Foutes to India and the East-The ENTERPRIzE-Lieut. Johnston, R.N.-Lieut. Waghorn, E.I.N.-East India Co.'s Bombay and Suez Service-The Peninsular Steam Navigation Co. (1834) altered to Peninsular and Oriental Steam Navigation Co. (1837)Sketeh of the Company's eareer-Snez Canal opened (1869) Calcutta and Burmah Steam Navigation Co. (1855)-Title ehanged to British India Steam Navigation Co., Limited (1862)-Bibby Line

CHAPTER X.-Steam on the Pacific-The Tesica (1825)-Mr. Wheelwright-The Pacifie steam Navigation Co. incorporated (18t0)Pioneer steamers CHILI and PERU-Sketeh of the Company's history

CHAPTER XI.-Freneh expedition to Algiers (1830)-Civil war in Portugal-Loss of the Rival (1832)-Mutiny on board the Lord Blaney (1831)-Loss of the Lord Blaney (1833)-Arrival of the Birmingham with news of the total defeat of Don Mignel (1833)The Margaret, first serew steamer trading from Hull; lost 1845...

CHAPTER XII.-Pioneers of Transatlantic Steam Navigation-Valentia Transatlantie Steam Navigation Co., incorporated 1828-Seheme revived 1835-Dr. Lardner's famous speech-His disclaimer, 1851The Royal Wildiam (of Canada), 1833-Dr. Julius Smith-British 
Queen Steam Navigation Co., 1836-British Quern (1838)-Sirius (1838)-Royal William (City of Dublin Co., 1838)-Liverpool (1838)-British and American Steam Navigation Co.'s steamer Prfisident, launched 1839 -Lost 1841 ..

CHAPTER XIII.-British Government and the Atlantic Mail ServiceMr. Samuel Cunard-Formation of the Cunard Line-The Grat Britain, launched 1843-Leaves Bristol for London-Inspected by H.M. Queen Victoria-Leaves London for Liverpool-First voyage to New York (1845)—Stranded Dundrum Bay (1846)-Re-floated

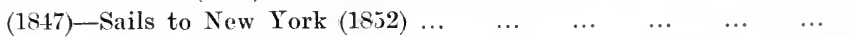

CHAPTER XIV.-Steam communication with the West Indies-The Royal Mail Steampacket Co. (1841), commences with a fleet of fourteen steamers-Generous concessions from Government-Rapid increase of trade-The "TRFNT affair"-First serew steamers for Company-The Imperial Direct West India Mail Service, Limited, established 1901

CHAPTER XV.-Early American Transatlantic Steamships-Massachusetts (1845)—Washington (1847)-The Collins Line-General deseription of steamers-Arrival at Liverpool of pioneer steamer Atrantic-Description of-Accident to Atlantic-Loss of steamers

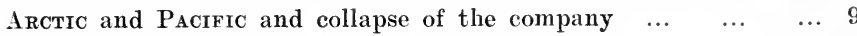

CHAPTER XVI.-The loss of the Collins Liner ARCtic $\quad \ldots \quad \ldots \quad \ldots 101$

CHAPTER XVII.-Steamship companies of the past (defunct or absorbed)-The Inman Line, 1850-Galway Line, 1859-National Line, 1863-Guion Line, 1866-Royal Atlantic Steam Navigation Co.

CHAPTER XVIII.-Liverpool and Glasgow Steamers-The ORIoN wrecked off Portpatrick, 1850-The steamer Neptune-A second Grace Darling

CHAPTER XIX.-The Eastern Steam Navigation Co.-Proposal to build a line of Leviathan steamers-GrEAT EASTERN-Contracted forAttempts to launch-Finally successful-Description of-Enormous loss to shareholders-Sails for New York-Carries troops to Canada -Lays Atlantic Cable-Is ultimately bought by "Lewis" for

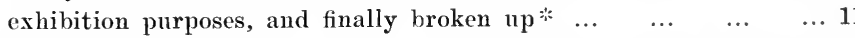

CHAPTER XX.-Steam to Australia-Sophia JANE-Great Britain-

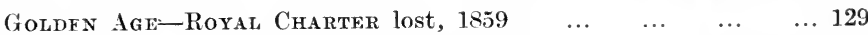

CHAPTER XXI.-Steamships in Chinese waters-Scothand (1860)-

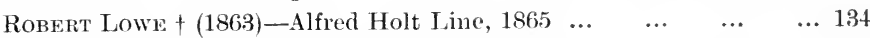

Errata.—* On page 127 read 1886 instead of 1896.

t On page 134 this vessel is called the Roвknт Bњuck in error. 
xiv.

CHAPTER XXII.-Remarkable History of the Glasgow Steamer FerRet 137

CHAPTER XXIII.-Anglo-Canadian Steamship Companies-McKean, MeLarty and Lamont-Allan Bros. \& Co._Canadian Pacific

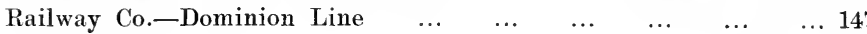

CHAPTER XXIV.-Railway Companies as steamship owners-South Eastern and Chatham Railway-London Brighton and South Coast Railway-London and South Western Railway-Great Western Railway-London and North Western Railway-Lancashire and Yorkshire Railway-Stranraer and Larne Service-Caledonian Railway-Glasgow and South Western Railway-North British Railway—Great Central Railway_Great Eastern Railway ... … 152

CHAPTER XXV.-Turbine Steamers-Turbinia-King Edward-

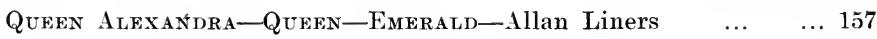

\section{PART II.}

$\begin{array}{llllllll}\text { CHAPTER } & \text { I.-Elder, Dempster } \& \text { Co. } & \ldots & \ldots & \ldots & \ldots & \ldots & 161\end{array}$

,, II.-African Steamship Co., Limited $\quad \ldots \quad \ldots \quad \ldots \quad \ldots l 66$

, III.-British and African Steam Navigation Co., Limited ... 171

, IV.-Imperial Direct West India Service, Limited ... $\quad \ldots 174$

, V.-City of Dublin Steampacket Co., Limited $\quad \ldots \quad \ldots 178$

, VI._British and Irish Steampacket Co., Limited $\ldots \quad \ldots 195$

$\begin{array}{llllllllll}, & \text { VII._Bibby Line } & \ldots & \ldots & \ldots & \ldots & \ldots & \ldots & \ldots & 203\end{array}$

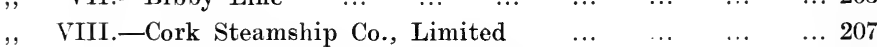

"

, $\quad$ IX.-Cunard Steamship Co., Limited $\ldots$..

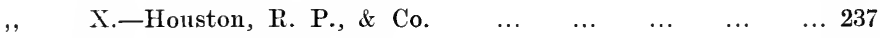

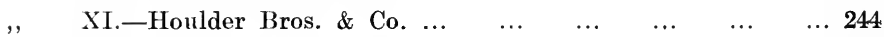

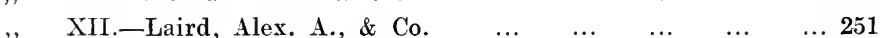

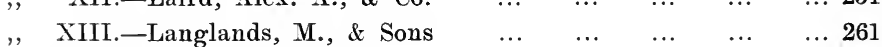

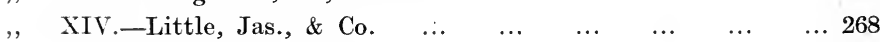

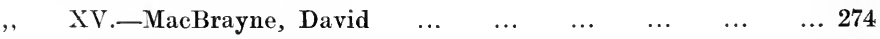

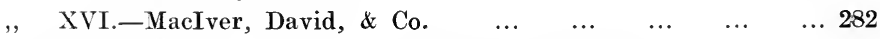

,, XVII.—MacIver's Liverpool and Glasgow Steamers... $\quad \ldots \quad \ldots 287$

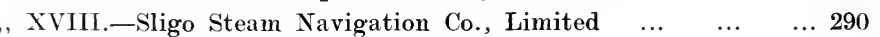

," XIX.—Waterford Steamship Co., Limited $\quad \ldots \quad \ldots \quad \ldots 293$

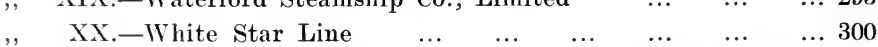

$\begin{array}{cccccccc}, & \text { XX.-White Star Line } & \ldots & \ldots & \ldots & \ldots & \ldots & \ldots \\ , & \text { XXI.-Adelaide Steamship } & \text { Company, } & \text { Limited-John } & \text { Bacon, }\end{array}$ Limited-R. Burton \& Sons, Limited-Fletcher, Woodhill \& Co.-T. \& J. Harrison-W. S. Kennaugh \& Co.-Lamport \& Holt-H. \& W. Nelson-R. \& J. H. Rea-John S. Sellers-

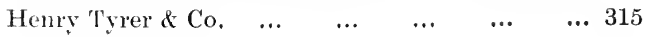




\section{LIST OF ILLUSTRATIONS:}

\section{PART I.}

Liverpool in 1837

PAGE

Frontispiece.

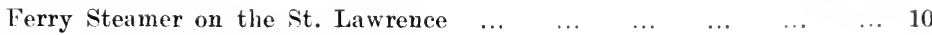

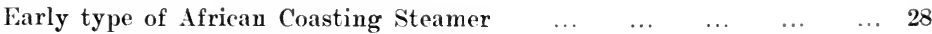

$\begin{array}{lllllllllll}\text { INVERARY CASTLE } & \text { P.S. } & \ldots & \ldots & \ldots & \ldots & \ldots & \ldots & \ldots & \ldots & 38\end{array}$

$\begin{array}{llllllllllll}\text { CоLомво s.s. } & \ldots & \ldots & \ldots & \ldots & \ldots & \ldots & \ldots & \ldots & \ldots & 46\end{array}$

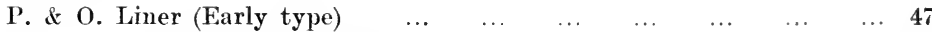

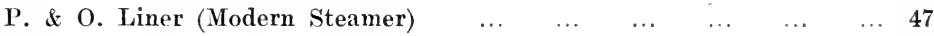

$\begin{array}{lllllllllll}\text { SicilitaN s.s. } & \ldots & \ldots & \ldots & \ldots & \ldots & \ldots & \ldots & \ldots & \ldots & 57\end{array}$

$\begin{array}{lllllllllllll}\text { PERU P.S. } & \ldots & \ldots & \ldots & \ldots & \ldots & \ldots & \ldots & \ldots & \ldots & \ldots & 59\end{array}$

$\begin{array}{llllllllllll}\text { OrEltana } & \text { s.s. } & \ldots & \ldots & \ldots & \ldots & \ldots & \ldots & \ldots & \ldots & \ldots & 61\end{array}$

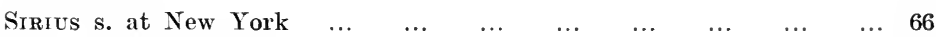

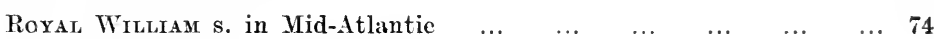

$\begin{array}{lllllllllll}\text { Grfat Britain } & \text { s. } & \ldots & \ldots & \ldots & \ldots & \ldots & \ldots & \ldots & \ldots & 80\end{array}$

$\begin{array}{lllllllllll}\text { CLYde R.M.s. } & \ldots & \ldots & \ldots & \ldots & \ldots & \ldots & \ldots & \ldots & \ldots & 86\end{array}$

$\begin{array}{llllllllllll}\text { Nile R.M.s. } & \ldots & \ldots & \ldots & \ldots & \ldots & \ldots & \ldots & \ldots & \ldots & \ldots & 87\end{array}$

$\begin{array}{lllllllllll}\text { PoRt ANTONIO R.M.S. } & \ldots & \ldots & \ldots & \ldots & \ldots & \ldots & \ldots & \ldots & 89\end{array}$

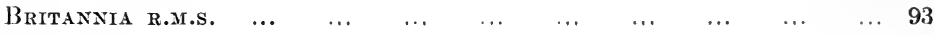

$\begin{array}{llllllllllll}\text { AsIA R.M.S. } & \ldots & \ldots & \ldots & \ldots & \ldots & \ldots & \ldots & \ldots & \ldots & \ldots & 97\end{array}$

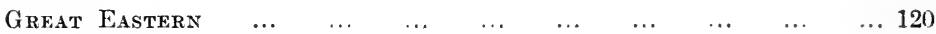

$\begin{array}{lllllllllll}\text { The Ferret s.s. } & \ldots & \ldots & \ldots & \ldots & \ldots & \ldots & \ldots & \ldots & \ldots & 140\end{array}$

$\begin{array}{lllllllllll}\text { Arrest of Conspirators } & \ldots & \ldots & \ldots & \ldots & \ldots & \ldots & \ldots & \ldots & 143\end{array}$

$\begin{array}{lllllllllll}\text { TUNisian R.M.s. } & \ldots & \ldots & \ldots & \ldots & \ldots & \ldots & \ldots & \ldots & \ldots & 148\end{array}$

$\begin{array}{lllllllllllll}\text { ARUndel s. } & \ldots & \ldots & \ldots & \ldots & \ldots & \ldots & \ldots & \ldots & \ldots & \ldots & 153\end{array}$

$\begin{array}{llllllllllll}\text { Glensannox } & \text { P.s. } & \ldots & \ldots & \ldots & \ldots & \ldots & \ldots & \ldots & \ldots & \ldots & 154\end{array}$

$\begin{array}{lllllllllll}\text { LuCY ASHTON P.S. } & \ldots & \ldots & \ldots & \ldots & \ldots & \ldots & \ldots & \ldots & \ldots & 15 j\end{array}$

PART II.

Sir Alfred L. Jones

Frontispiece.

IV. J. Davey, Esq.

... 166

JEBBA R.M.s.

... 170

TARQUAH R.M.s. 
xvi.

Port Royal R.M.s

ULSTER R.M.S.

Royal William P.s.

Holyhead Mail Steamer

Wm. Watson, Esq

.. 187

LADY RoBERTS s.s.

... 192

LADY WOLSEley s.s.

196

Bibby Liner

.. 201

Ehonezer Pike, Esq.

204

SIRIUS

Rissa

212

RIssa s.s.

.. 218

Joseph Pike, Fsq.

. 220

Liverpool Landing Stage

.. 222

Furopa and America R.M.s.

.. 224

Scotia R.m.s. .

.. 226

Russia R.M.s.

.. 228

Etruria R.M.s.

.. 232

LCCANIA R.M.s.

.. 234

Hydaspes s.s.

.. 238

Oswestry Grange s.s.

.. 244

Bracon Grange s.s.

.. 246

Hornby Grange s.s.

.. 248

Rose s.s.

.. 250

Mlex. A. Laird, Esq.

.. 254

Olive s.s.

Princess Maud s.s.

Princess Royal P.s.

Claymore R.M.s.

.. 258

... 262

... 264

Columis R.M.s.

... 274

Clodagh s.s.

.. 280

T. H. Ismay, Esq.

OCFanic (first)

.. 294

Teltoxic R.M.s.

Oceanic (second) .. 300

Chltte r.m.s. ..

.. 305

... 307

... 311

Cymric m.N.s. ... 


\title{
History of Steam Navigation.
}

\author{
Part I. \\ ITS ORIGIN AND EXPANSION.
}

Chapter I.

Inventors and alleged Inventors prior to 1807.

THERE is not a more fascinating page in history than that which tells of the growth of the Mercantile Steam Navies of the World. It is a record of the triumphs of Science and Art in Marine Architecture; of bold enterprises-not always carried to a successful financial issue; of deeds of "derring do" as romantic as the older stories of the Vikings. It is a page brightened by stories of true heroism, where men have bravely faced death, not in the lust of battle, but in calm devotion to duty, or in unflinching determination to save the lives of those weaker than themselves.

It is not possible, nor would it answer any useful purpose, to discuss fully the various claims which have been put forward for the honour of having invented the first Marine Steam Engine. It will be sufficient to refer briefly to the inventors, or alleged inventors, prior to the year 1807 .

In the Appendix to Señor Navarette's "History of the Four Voyages of Columbus," are copies of certain documents which the historian vouches to be authentic extracts from the series of Spanish Records preserved at Simancas. These documents narrate " that in the month of May or .June, 1543, Blasco de 
"Garay, a naval captain in the service of the Emperor "Charles V., conducted at Barcelona, a series of experiments "upon the applicability to ships of a certain propulsive "force, which he alleges he had himself discovered." De Garay describes the mechanism he employed as consisting of two wheels, one attached to either extremity of a movable axis which traversed the vessel's waist, and was connected with a large caldron of boiling water. The experiments, it is alleged, were conducted in the presence of several persons of high birth, deputed by the Emperor to witness them, and amongst whom were many naval commanders. It is further alleged that De Garay succeeded in taking to sea a vessel of two hundred tons burthen, without the aid of sail or oar, and that her speed was about one league per hour.*

Rear-Admiral Geo. Preble, U.S.N., author of a "History of Steam Navigation," gives the names of several persons who have searched the documents referred to, none of whom have been able to trace any mention of steam; he, therefore, concludes that the account of De Garay's invention is a Spanish legend.

+Papin, who was driven from France by the revocation of the Edict of Nantes, and was elected F.R.S. in 1681, describes, in 1690, a steam cylinder in which a piston descends by atmospheric pressure, and, as one of its uses, he mentions the propulsion of ships by paddle wheels. Towards the close of the 17th century, or the beginning of the 18th, Papin made the acquaintance of Thomas Savory, one of the most ingenious men of his times, and of Thomas Newcomen, a working blacksmith, of Devon. Savory designed a marine engine, which was greatly improved by Newcomen in 1705 , and was used by Papin to propel a steamboat on the Fulda.

Thirty years later (1736), Jonathan Hulls, of Berwick-onTweed, received a patent for the first steamboat of which there is any authentic record from George II., which recited as follows:-

* "Chambers' Journal."

† Hy. Fry, ex Pres. Dominion B/T. Canada and Lloyd's Agent at Quebec, author of a "History of North Atlantic Steam Navigation." 1896. 
*"Whereas our trusty and well-beloved Jonathan Hulls "hath by his petition humbly represented unto our most "dearly beloved C'onsort, the (Queen, that he hath, with " much labour and with great expense, invented and " formed a machine for towing ships and vessels out of, or " into any harbour or river, against wind or tide, or in a " calm, which the petitioner apprehends may be of great "service to our Royal Party and merchant ships, and to "boats and other vessels, of which the petitioner hath " made oath that he is the sole inventor, as by affidavit to " his said petition annexed.

" Know ye, therefore, that we, of our special grace, hath "given and granted to the said. Jonathan Hulls our " special license, full power, sole privilege and authority "during the term of fourteen years, and he shall lawfully " make use of the same for carrying ships and other " vessels out to sea, or into any harbour or river.

"In witness whereof we have caused these our letters to " be made patent.

"(Witness) CARoline, " (queen of Great Britain, \&c.

"Given by right of Privy Seal at Westminster, this "21st day of December, 1736.",

In the description of his invention, Hulls states that, in his opinion, it would not be practicable to place his machine on anything but a tow-boat, as it would take up too much room for other goods to be carried on the same vessel with it, and it could not " bo used in a storm, or when the waves are very raging." Hulls' vessel is stated to have been a stern-wheeler, a type of steamboat which is now extensively user for navigating shallow rivers in the Southern States of America and in India. The steam tow-boat brought its inventor nothing but ridicule, and he died in London in almost destitute circumstances.

Next in chronological sequence come the Abbé Arnal and the Marquis de Jouftiroy, of France, who, in 1781, marle 
experiments to show the practicability of applying steam power to vessels.

Two years later (1783), a Mr. Fitch tried a species of steam boiler on board a small nine-ton vessel on the Delaware River in America, propelling the vessel by paddles. * "In 1787 he " built another boat, $45 \mathrm{ft}$. by $12 \mathrm{ft}$., and fitted her with a $12 \mathrm{in}$. " cylinder. With this vessel he is reported to have made the " trip from Philadelphia to Burlington at an average rate of " seven miles per hour. In 1790 he completed another and a "larger boat." But all his plans failed, and, like Hulls, his contemporaries deemed him to be crazy. He died in 1798.

+ About this period (1780 to 1788) there resided in Edinburgh a banker, of aristocratic birth and connection. Patrick Miller, the banker referred to, was a man of an active and ingenious mind, and, having realised a large fortune by banking, he used it as a means of enabling him to work out schemes for the benefit of the public. Having purchased an estate in the beautiful valley of the Nith, from which he derived the title of Laird of Dalswinton, he retired thither to solve the problem of navigating a vessel by some more certain means than oars and sails. He had (prior to this) $\ddagger$ "exhibited " a triple vessel at Leith, having rotatory paddles in the two " interspaces, driven by a crank and wrought by four men. He " determined one day to try its powers against a fast sailing "Customs Wherry, between Inch-colm and the harbour of "Leith, a distance of six or seven miles. He beat his "opponent by several minutes, and was very well satisfied "with the result. His boys' tutor, a Mr. Taylor, who had " taken his turn at the erank, and realised how violent was the " necessary exertion, was convinced that without a more " staying power than manual labour the invention would prove "practically useless. He stated his objections to Mr. Miller, " and they had frequent discussions on the subject. At length, "one day, Taylor said 'Mr. Miller, I can suggest no power " equal to the steam engine, or so applicable to your purpose.' "The result of this suggestion was that Mr. Miller decided to

* Hy. Fry.

+"Chambers' Journal." $\quad$ + "Chambers' Journal," 1857. 
" fit up a new double boat, which he had recently placed on "the lake at Dalswinton for the amusement of his family. "Taylor made the necessary arrangements under the direction " of an ingenious mechanic named William Symington. The " engine was a very small one, having four-inch brass " cylinders, made by George Watt, brassfounder, Edinburgh.

"On the 14th October, 1788, several hundreds of people " assembled on the banks of Dalswinton Loch to witness the "trial trip of the twin steamboat, which was entirely "successful. Mr. Miller was so pleased with the success of " the experiment that he resolved to repeat it on a larger scale. "The following year he fitted a twin vessel 60 feet long, " belonging to himself, with an engine of $18 \mathrm{in}$. cylinders. "This vessel steamed at the rate of seven miles an hour on the

"Forth and Clyde Canal, in the presence of a vast multitude " of spectators. It had been Mr. Miller's wish to try a third " experiment with a third vessel, in which he should venture " out on to the ocean, and attempt a passage from Leith to "London. Unfortunately, he became dissatisfied with "Symington, and, being vexed at the cost of fitting up the " second vessel, which was much greater than he anticipated. " as well as by a miscalculation, through which the machinery " was made too heavy for the hulls, he hesitated to make " further trial.

"Taylor being poor, and a scholar, not a mechanician, could " do nothing without Mr. Miller's assistance. Symington was " the only one of the three who persevered. He deserves " credit for having done so, but not for the manner in which "he did it, for without any communication with Messrs. "Miller and 'Taylor, the true inventors, he took out a patent "for the construction of steamboats in 1801. Through the " interest of Lord Dundas, he was able, in 1803, to fit up a new "steamboat for the Forth and Clyde Canal Co., and this vessel, " called the Charlotte Dundas, was tried in towing a couple "of barges upon the canal with entire success, except in one " respect, which was that the agitation of the water by the "paddles was found to wash down the banks in an alarming "manner. For this reason the Canal Co. resolved to give up 
" the project, and the vessel was, therefore, laid aside. It lay " on the bank at Lock 16 for many years, generally looked on, " of course, as a monument of misdirected ingenuity, but, as " we shall presently see, it did not lie there altogether in vain.

"Meantime Symington had been in communication with the

. Duke of Bridgewater, with the object of introducing steam

" towage on the Bridgewater (anal, and had actually received " a trial order, when, unfortunately, the Duke died, and the "project was closed. Here Symington vanishes likewise from " the active part of this history. Miller died in 1815, a com"paratively poor man, having exhausted his fortune bv " improvements and experiments. It has been stated by his " son that he spent fully $£ 30,000$ in projects of a purely public ". nature. Taylor died in 1824, in straitened circumstances, "leaving a widow and daughters, to whom the Government " granted a pension of $£ 50$ a year.

"The experiments at Carron, in 1r89, had been witnessed " by a young man named Henry Bell, a working mason origin" ally, as it appears, afterwards a humble kind of engineer in

"Glasgow, and later an hotel proprietor at Helensburgh. Bell

" never lost sight of the idea, and when Symington ceased ex"perimenting in 1803 he took up the project. At the same " time an ingenious American, named Fulton, comes into the " field. He, in company with Bell, visited the Charlotte " Dundas in 1803, and Bell gave to Fulton drawings of the "machinery which he (Bell) had obtained, partly from Mr. " Miller and partly from Symington."

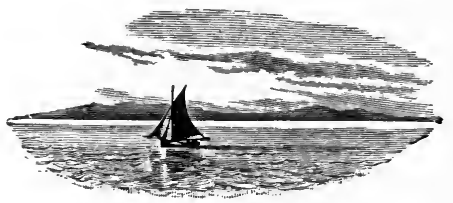




\section{Chapter II.}

Fulton (1807).-The Clfirmont, the first Passenger Steam-boat in the world.-Narrative of her first Voyage.-Steam Navigation in Canadian Waters.-The first Steamers on the St. Lawrence.-The Accommodation (1809).--Swiftsure and Car of Commerce (1813), and the Quebec (1817).

The United States of America has the honour of having built the first passenger steam-boat in the world, and she held the monopoly of the steamship passenger traffic for a period of about two years. She owes this honourable position in the commercial world to the energy and perseverance of Robert Fulton, who in spite of ridicule and active opposition, and want of capital, succeeded in building, in 180\%, a paddle steam-packet, which he named the Clekmoxt. Shortly after her trial trip, she was advertised to run from New York to Albany, and, as soon as she could be got ready, the Clemsoxt sailed on her first voyage up the Hudson.

The following extract from a letter, written by an eyewitness on that occasion, tells how the people along the river were excited by the passage of the steam-boat on her voyage from New York to Albany:

"It was in the early autumn of the year $180 \pi$ that a "knot of villagers was gathered on a high bluff, just " opposite Poughkeepsie, on the west bank of the Hudson, " attracted by the appearance of a strange-looking craft. " which was slowly making its way up the river. Some " imagined it to be a sea-monster, whilst others did not "hesitate to express their belief that it was a sign of the "approaching judgment. What seemed strange in the " vessel was the substitution of a loftv and strange black " smoke-pipe rising from the deck, instead of the grace"fully tapered masts that commonly stood on the vessels 
" navigating the stream, and, in place of the spars and "rigging, the curious play of the working beam and "piston, and the slow turning and splashing of the huge

" and naked paddle-wheels, met his astonished gaze. The

"dense clouds of smoke, as they rose wave upon wave, " added still more to the wonder of the rustics.

"This strange-looking eraft was the Clermont on her " trial trip to Albany; and, of the little knot of villagers "above mentioned, the writer, then a boy in his eighth "year, with his parents, formed a part; and I well "remember the scene, one so well-fitted to impress a

"lasting picture upon the mind of a child accustomed to

" watch the vessels that passed up and down the river.

"On her return trip, the curiosity she excited was "scarcely less intense the whole country talked of " nothing but the sea-monster, belching forth fire and "smoke. The fishermen became terrified and rowed

"homeward, and they saw nothing but destruction de"vastating their fishing grounds; whilst the wreaths of "black vapours, and rushing noise of the paddle-wheels,

" foaming with the stirred up waters, produced great

"excitement amongst the boatmen, until it was more

" intelligent than before; for the character of that curious

"boat, and the nature of the enterprise she was pioneering

"had been ascertained."

Several accidents occurred to the machinery of the Cuermoxt during her first season, but none of them caused any loss of life. There were, however, so many of these mishaps that the incredulous were encouraged in the belief that she was a failure. But the misfortunes of the boat were not limited to accidents to machinery and other legitimate mishaps. They included wilful attempts at her destruction on the part of those who felt that their business was about to be injured by this new system of navigation. Vessels ran foul of her intentionally, and so determined were the sloop owners and others to rid themselves of this dangerous competitor, that it became necessary for the Legislature to interfere. But in spite of all opposition, Fulton forced his way onward and 
upwards. He replaced his first steamer by a second and larger one, also named the ('skrmont, and, as the passenger trade developed, other steamer's were added to the line.

American capitalists in different parts of the Linited sitates followed his example. Steamers were built so rapidly to ply on the American Atlantic Seaboard, and on the Mississippi and other rivers, that in 182:) (that is sixteen years after the first passenger steamer in the world was built) there were 300() steamers plying on American waters.

The St. Lawrence is the chief dividing line between the United States and Canada. It forms the great summer highway for the traffic of British North America. By it the commerce of Europe is brought into the country, and on its bosom is borne outwards the wealth of the forests and the surplus agricultural produce of the Dominion.

(On the Canadian side of this great river are situated the two important cities of Quebee and Montreal. Two years (1809) after the building of Fulton's ('swrmost, and three years before the first European steamer began to ply on the River Clyde, the steamboat Aссомmonstion ran on the st. Lawrence, maintaining a passenger service between (quebec and Montreal.

The following account of this vessel, and of her first voyage, appeared in the "Quebec Mercury" of that date:-

"On Saturday morning at eight oclock arrived here " from Montreal, being her first trip, the steamboat "Acсомmodation, with ten passengers. This is the first " vessel of the kind that ever appeared in this harbour. "She is continually crowded with visitants. She left "Montreal on Wednesday, at two o'clock, so that her " passage was sixty-six hours, thirty of which she was at "anchor. She arrived at Three Rivers in twenty-four

" hours. She has at present berths for twenty passengers, " which next year will be considerably augmented. No “ wind or tide can stop her. She has 75 feet keel, and 85 " on deck. The price for a passage up is nine dollars, and " eight down-the vessel supplying provisions. The great "advantage attending a vessel so constructed is, that a 
"passage may be calculated on to a degree of certainty,

" in point of time, which cannot be the case with any vessel

" propelled by sails only. The steamboat receives her

" impulse from an open double-spoked, perpendicular

"wheel, on each side, without any circular band or rim.

"To the end of each double spoke is fixed a square board,

"which enters the water, and by the rotary motion of the

" wheel, acts like a paddle. The wheels are put and kept

" in motion by steam, operating within the vessel. A

" mast is to be fixed in her for the purpose of using a sail

"when the wind is favourable, which will occasionally

"accelerate her headway."

In 1813 two new steamers were placed on the St. Lawrence, called respectively the Swiftsure and the CAR of Commerce, and, after a further interval of four years, a fourth steamer, the (Lueisec, began to ply between Quebec and Montreal.

The first of these steamers, the SwirTsure, was 140 feet over all, with a beam of 24 feet. On her maiden voyage she made the passage from Montreal to Quebec in twenty-two and a half hours, in the face of a strong easterly wind all the way. Notwithstanding that she ". beat the most famous of the sailing "packets on the line (fourteen hours in a race of thirty-six "hours), her owners do not seem to have been very confident "of her movements under all circumstances, or of the number "of passengers who would patronise her, for she was adver" tised to sail "as the wind and passengers may suit." ”

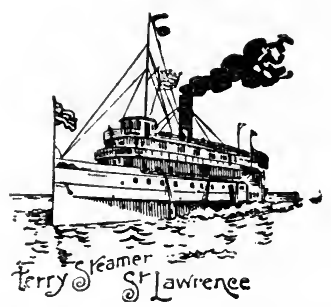




\section{Chapter III.}

Steamboats on the River Clyde, the Conet, Industry, Argyle.-On the Thames, the Margery and the Thames.-The first Irish Steamer, the Сity of Cork.

Wiтhout, in the slightest degree, detracting from the credit due to the inventors referred to in the earlier pages of this history, it is indisputable that the River Clyde is the birthplace of European Steam Navigation.

For many years the Charlotte Dundas (a success from an engineering point of view, but a failure commercially), lay idle and corroding at Lock 16 on the Forth and Clyde Canal. She was regarded by the majority of those who saw her there, as a monument of Symington's folly-the embodiment of a "fad."

Bell, however, throughout these years, retained his faith in the ultimate success of the Marine Steam Lingine. There seemed to be no probability of steam being utilized as a motive power for vessels in British waters, but the Americans were more enterprising, and Fulton, who accompanied Bell to inspect the Charlotte Dundas in 1803, gave the latter to understand that he had influential friends in America, whom he could induce to build steamers. Bell had good reason to consider himself badly treated by Fulton in this matter, yet, undoubtedly, indirectly Bell was benefited by Fulton's success. It is more than probable that during the five years that succeeded the building of the Clermont, frequent reports regarding both this vessel and her successors in the United States and Canada, reached Scotland. And as a consequence of the success of these boats, Bell succeeded in getting a small steamer built to trade on the River Clyde. The following is a copy of Mr. Bell's advertisement of the sailing of his steamer:-

"The Coner, between Glasgow, Greenock and Helens- 
" burgh, for passengers only. The subscriber having at " much expense, fitted up a handsome vessel to ply upon "the River Clyde, between Glasgow and Greenock, to sail " by the power of wind, air, and steam, he intends that the "vessel shall leave the Bromielaw on Tuesdays, Thursdays, " and Saturdays, about mid-day or such hour thereafter as "may answer from the state of the tide; and to leave

"Greenock on Mondays, Wednesdays, and Fridays, in the "morning to suit the tide. The terms are fixed for the "present at $4 \mathrm{~s}$. for the best cabin, and $3 \mathrm{~s}$. for the second;

"but beyond these rates nothing is to be allowed to servants " or any other person employed about the vessel."

The Comet was a steamer of 25 tons burden, 40 feet long, and 10 feet 6 inches broad, and she steamed about 5 miles per hour.

A correspondent of the "Steamship" (1st January, 1883), relates regarding one Dougal Jamson, a Clyde skipper, of the time of the COMEт, that whenever the steamboat passed his slow going sloop, he invariably piped all hands - a man and a boyand bade them " Kneel down and thank God, that ye sail wi' the Almichty's ain win', an' no' wi' the deevil's sunfire an' brimstane, like that spluttery thing there."

The following year there were three additional steamers constantly plying on the Clyde between Glasgow and Greenock. One of these was probably the steamer (whose name has not been recorded), which came from the Clyde to Liverpool in 1815. The second of this trio was the Industri, whose remains were to be seen more than half a century later at Bowling. And the third was the steamer Argrue, afterwards re-named the Thames.

All these boats were faster than the Comer, and were twice as large, being 75 feet long and 14 feet broad. Against such competitors the Comet could not compete successfully. In his later years Bell received a small annuity from the Clyde 'Trustees, who, after his decease, erected an obelisk to his memory, which may still be seen standing on a rock a little below Bowling.

For two or three summers Glasgow was the only ('ity in 
Great Britain or Ireland whose citizens enjoyed the advantages of steam packet communication with the coast. But, in the summer of the year 1815, the citizens of London and of Cork were given equal facilities.

Ireland has always occupied a most honourable position in the Annals of Steam Navigation. Cork had a steamship service certainly as early as Liverpool; the pioneer of the Liverpool coasting steamship trade was a Belfast steamer; from Cork, sailed the first steamer with passengers from liurope to America; the first Trans-Atlantic Liner from Liverpool was a Dublin steamer; and in this year of grace 1903, the steamer's built in Belfast, which carry the White Star flag across the Atlantic and Pacific Oceans, have a reputation unsurpassed by any steamships afloat. But Cork anticipated Belfast in shipbuilding and ship-owning. Messrs. Michael O'Brien and Christopher Owens, of Cork, were the first to introduce steamers to the merchants and travelling public of the South of Ireland. They built, in 1815, the river steamer City of Conk. She was a wooden paddle steamer of 50 tons register; and of slightly larger dimensions than the Clyde-built steamers referred to, being 86 feet long, 13 feet broad, and 9 feet deep.

The steam fleet of the Thames consisted at this date of the three steam-packets Marjory, Defiance and Thames, which steamers plied between London and Margate. The Dewaxce, probably a locally built vessel, was commanded by William Robins, and sailed from near Summer Quay, Billingsgate, every Sunday and Wednesday morning, at $\tau$ o'clock, returning from Margate every Tuesday and Friday morning.

"The Thumes, steam yacht," (says the London "Times," of the 8th July, 1815), " from London to Margate, starts from Wool Quay, near the Custom House, Thames Street, every Tuesday and Saturday at 8 o'clock a.m., precisely, and leaves Margate on her return to London every Monday and Thursday at the same hour. This rapid, capacious and splendid vessel lately accomplished a voyage of 1,500 miles, has twice crossed St. George's Channel, and came round the Land's End with a rapidity unknown before in naval history, and is the first steam ressel that ever traversed those seas. She has the peculiar 
advantage of proceeding either by sails or steam, separated or united, by which means the public have the pleasing certainty of never being detained on the water after dark, much less one or two nights, which has frequently occurred with the old packets. Against the wind, the tide, or in the most perfect calm, the passage is alike certain, and has always been achieved in one day. Her cabins are spacious, and are fitted up with all that elegance could suggest, or personal comfort require; presenting a choice library, backgammon boards, draught tables, and other means of amusement. For the express purpose. of combining delicacy with comfort a female servant attends upon the ladies. The fares (which include Pier Duty) are in the Chief Cabin 15s., and in the Fore Cabin 11s., children half price. No articles or goods will be taken, except the luggage accompanying passengers; and the proprietors will not be answerable for any of the above, unless delivered into the eare of the Steward, nor to the amount of more than $£ 5$ value, except entered and paid for as such."

A narrative of the remarkable voyage of this steamer from the Clyde to the Thames, referred to in the above quotation from the "Times," will be found in the following chapter.

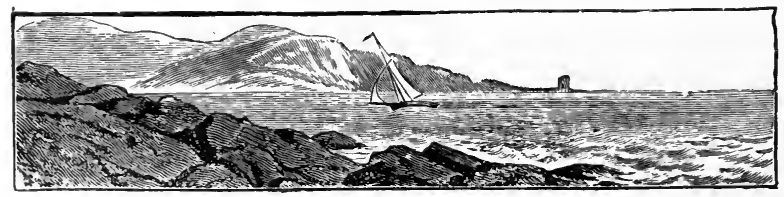




\section{Chapter IV.}

"The Year 1815."

To the student of British history, the year 1815 is one of the most remarkable of the nineteenth century. In June of that year was fought the Battle of Waterloo-a victory for the British which effectually destroyed the power of the first Napoleon, and delivered Europe from the terror of a military despotism. The merchants of the "good old town" of Liverpool were determined that the famous victory should never be forgotten by their descendants, and so they perpetuated the name in the "Waterloo Road," the "Waterloo 1)ock," and their latest seaside suburb "Waterloo." Another event occurred in that same eventful month of June, 1815, an event unheralded at the time, but whose results have been more widely spread and more beneficent than those which resulted from the Battle of Waterloo. This was the arrival from the Clyde of the first steamer ever seen on the river Mersey. The following brief and unsatisfactory paragraph appeared in the "Liverpool Mercury" of the 30th June:-

"Liverpool Steamboat.—On Wednesday last, about

" noon, the public curiosity was considerably excited by

" the arrival of the first steamboat ever seen in our river.

" she came from the Clyde, and in her passage called at

"Ramsay, in the Isle of Man, which place she left early

" on the same morning. We believe she is intended to

"ply between this port and Runcorn, or even occasionally

" as far as Warrington. Her cabin will contain about

" one hundred passengers."

This is one of the most tantalising paragraphs ever printed. If " the public curiosity was considerably excited," the reporter" certainly took no pains to gratify it. The name of the vessel is 
not given, nor any particulars of her dimensions, or of her power and speed. The daring mariners who navigated her are nameless, and the incidents of this pioneer voyage are left unrecorded.

"The evil that men do lives after them, The good is oft interred with their bones."

Fortunately we are able, from other sources, to gather some idea of the size and appearance of the vessel, and of the impression she made on the minds of the spectators. She was presumably one of the three steamers built on the Clyde in 1813, as competitors against the СомЕт, for passengers between Glasgow and Greenock; the other two were the ArgrLe and the INDustry. There was only a difference of five feet between the smallest and the largest of these three steamers, so that a description of the ARGYLE will answer for the others as well. The ARgrle was a packet steamer of 70 tons register, measuring in her keel 79 feet, with 16 feet beam, paddle wheels 9 feet in diameter, and engines 14 h.p. Her smoke was carried off by a funnel, which also did duty as a mast, being rigged with a large square sail. A gallery, upon which the cabin windows opened, projected so as to form a continuous deck, interrupted only by the paddle boxes, an arrangement which had the further effect of making the vessel appear larger than she really was. On the outside of the gallery eighteen large port holes were painted, which, with the two she displayed upon her stern, made the ARGYLE look so formidable to those to whom a steamer was a novelty, that it was stated in a Committee of the House of Commons, by several naval officers, that if they had met her at sea they would have endeavoured to reconnoitre before attempting to bring her to. After plying for twelve months between Glasgow and Greenock, the ARGYLE was sold to a London firm, who changed her name to the Tinames. In consequence of this change of ownership, this vessel made one of the most remarkable voyages ever accomplished by any steamer. An interesting narrative of the voyage, from which these particulars are taken, was published in "Chambers' Journal " on the 25th April, 1857.

The task of bringing the little steam-packet round by sea 
from the Clyde to the Thames, was intrusted to an ex-naval officer named 1)odd, a man of considerable and diverse abilities. He projected the Thames tunnel, proposing to carry it across from Gravesend to Tilbury, at an estimated cost of under $£ 16,000$. According to an account of the voyage which Dodd himself published in the "Morning Chronicle" of the 15th June, 1815, and afterwards embodied in his evidence before a Committee of the House of Commons, Dodd sailed from Glasgow about the middle of May with a crew of eight persons -a mate, an engineer, a stoker, four seamen, and a cabin-boy. His voyage at first was far from auspicious. The weather was stormy, the sea ran high in the strait which separates Scotland from Ireland, and either through ignorance or negligence, the pilot during the night altered the course of the vessel, so that it ran a great risk of being wrecked. Dodd had given orders that the steamer should be steered so as to gain the Irish coast by the morning; but at break of day a heavy gale was blowing, and it was discovered that, instead of being off the coast of Ireland, they were within half-a-league off a lee shore, rock bound, about two miles to the north of Port Patrick. Relying entirely upon the efficiency of his engine, Dodd at once laid the vessel's head directly to windward, and ordered the log to be kept constantly going. The plan succeeded. The Thumss began slowly to clear the shore, going direct in the wind's eye at the rate of something more than three knots an hour. On the 24th of May the voragers arrived safely at I)ublin, where they were joined by a Mr. Weld and his wife. Mrs. Weld has the proud distinction of having been the first lady passenger to cross the St. Cieorge's Channel on a steamboat. Mr. Weld kept a journal, from which the following is an extract:-

* "On the 25th May, 1815, I heard by accident that a "steam-vessel had arrived at Dublin. I immediately " went to see her, and found her on the point of starting "with a number of curious visitors upon an experimental " trip in the bay. I was so much pleased with all that I " saw and heard concerning her, that, having previously " intended to proceed to London, I determined to request * "Chambers' Journal," 25th April, 1857. 
"Captain Dodd to receive me as a passenger, and to be "permitted to accompany him throughout the voyage. "He at once consented, and my wife having resolved on "sharing the dangers of the voyage with me, we pro"ceeded to make the necessary arrangements for our "departure. On the 28th of May, being Sunday, we left " the Liffey at noon. Many persons embarked with us "from curiosity, but only to cross the bay as far as "Dunleary (now Kingstown), where they landed. "Unfortunately, the sea was very rough, which "occasioned the most violent sea-sickness amongst the "passengers. Several naval officers were on board, who "were unanimous in declaring it to be their firm opinion " that the vessel could not live long in heavy seas, and "that there would be much danger in venturing far " from shore. I deemed it right to inform my wife of this "opinion, but, although she suffered greatly from sea" sickness, she persisted in her intention of accompanying "me, and that evening, after having passed some hours " on land at the house of a friend, the vessel put to sea, " we being the only passengers. The shore was covered "with several thousands of spectators, who cheered and " wished us a prosperous voyage.

"The sea was comparatively calm as the ressel steamed " into the Bay of Dalkey, and the passengers calculated "on a pleasant voyage during the night, but, when " beyond the shelter of the coast, they found it to be as " rough as ever. The Triames again proved her admir" able sea-going qualities, bounding so lightly over the "waves that her passengers were not once wetter, even by "the spray."

She soon left behind her all the vessels which had sailed from 1)ublin with the same tide, and about nine o'clock next morning arrived off Wexford. The dense smoke which issued from its mast chimney being observed from the heights above the town, it was conchuded that the ressel was on fire. All the pilots immediately put off to its assistance; and nothing could exceed their surprise, mingled with disappointment, when they saw that the ship was in no danger whatever, and that their hopes of salvage were at an end. 
The weather had now become so stormy, that Captain Dodd determined to put into port, his great object being to navigate the vessel safely to London, rather than, by using great dispatch, to expose her to unnecessary risk.

At two o'clock on Tuesday morning, 30th May, Dodd left Wexford and sailed for St. Mavil's Head, the most westerly point of Wales. Juring the passage across St. George's Channel one of the blades of the starboard paddle wheel got out of order. The engine was stopped and the blade cut away. Some hours after a similar accident befell the port wheel, which was remedied in the same manner. The loss of one blade in each wheel made no apparent difference in the speed of the vessel. Fortunately when the accidents occurred the sea was very calm. After a voyage of twelve hours duration, the steamer arrived at the Pass of Ramsay, between the island of that name and St. Mavid's Head. There the adventurers remained for three hours to oil the engine, and to give the stoker, who had not quitted his post for an instant since leaving Wexford, a little rest. There, too, as at Wexford, boats put out from different parts of the coast to the assistance of the vessel, which they believed to be on fire. Leaving Ramsay, the Thames steamed through the straits and across St. Bride's Bay. The weather had again become unfavourable, and a heavy sea had arisen in the bay. So high indeed were the waves, that, when ingulphed between them, the coast, though lofty, could not be seen; but the little craft held her way most gallantly over all.

On the south side of St. Bride's Bay, between Skomar Island and the mainiand, there is a dangerous passage called .Jack Sound. The pilot warned the captain against attempting this passage, except under favourable conditions as to wind and water, but Dodl, who knew the power of his engine, insisted on going through the sound, in orler to save fire hours, and to avoid another night at sea. The dangerous sound was safely navigated, and the voyagers reached Milford Ilaven. As they were steaming up the harbour, they met the Government mail packet proceeding from Milford to Waterford, with all her sails spread. They had passed her about a quarter of a mile, when 
Captain Dodd determined to send some letters by her to Ireland. The Thames was immediately put about, and in a few minutes she was alongside the packet ship, and sailed round her, although the latter continued under way. The captain and passengers wrote a few letters, put them on board the packet, sailed round her once more, and then continued their course to Milford.

The two following days were spent in satisfying the curiosity of numerous naval officers who were anxious to see the Thames, and to examine her engine, as well as to test her sailing powers. It became necessary also to clean out the boiler, which had not been done since leaving Glasgow. Late on the evening of the 31st May, she sailed in company with the Mrrtue, sloop-of-war, whose captain (Bingham) and a company of ladies were aboard the steamer, anxious to see how she would behave in a rough sea. The Mrrtue was obliged to hoist royals and studding sails to keep up with the Thumes, and at last by crowding all sail, she got a little ahead. But the great superiority of steam was yet to be shown. Dodd gallantly determined to carry the ladies back to Milford, instead of transferring them to the MrRTte in an open boat. Accordingly he steamed back to Milford, leaving the sloop of war far behind, and when he was again outward bound, he found the sloop had anchored, being unable owing to the failure of the wind to regain her former station. Next morning (Friday) the voyagers found themselves mid-way across the Bristol Channel, with no land visible on either side, but towards evening the Cornish coast was sighted. The weather, however, had again become threatening, and the pilot did not consider it would be prudent to attempt to round the Land's End that night, and Dodd accordingly decided to put into St. Ives. As the Trumes approached the shore, a fleet of small craft was seen making towards her, with all possible speed by means of sails and oars, in the belief (as at Wexford) that the Thames was a ship on fire making for the port. When they discovered their mistake they tacked about and endeavoured to out-sail each other. All the rocks from which a view of St. Ives could be obtained were crowded with spectators, to whom the appearance of the Tнaмss 
created as much surprise as the ships of (aptain Cook produced amongst the islanders of the South Sea. The harbour of St. Ives affording no shelter from gales from the North East, Dodd took his vessel to the sheltered port of Hayle, four miles distant, where she lay in perfect safety. It had been represented to Mr. and Mrs. Weld that rounding the Land's End was the most difficult and dangerous part of the voyage, and they had in consequence crossed the neck of land to the South coast with the intention of remaining there until the steamer arrived. On further consideration, however, they resolved, instead of waiting for the Thames, to return to Hayle, and to brave with the steamer's crew the dangers of doubling the Land's End. The weather having moderated they re-embarked at 4 o'clock on Monday afternoon, 5th June, and the steamer at once proceeded on her voyage.

As the little vessel rounded Cornwall Head, the more northerly of the two great promontories which terminate England on the west, a tremendous swell from the Atlantic met her, whilst the tide, which ran strongly down st. George's Channel, combining with the swell, raised the waves to such a height as to render her position in the highest degree alarming. Dodd would not put back, and after a night of severe struggle, the adventurers succeeded in rounding the Land's End, and found themselves in a comparatively tranquil sea. Next day the sun shone with great brilliance, and revealed the beauties of the South Coast as they steamed along it towards Plymouth, which they reached at eleven o'clock in the morning. As the Thames passed the various ships at anchor, the sailors on board ran in crowds to the sides of their vessels or climbed the rigging for a better view. The harbour-master, who had never seen a steam vessel before, was as much excited when he boarded the Thames as a child is in getting possession of a new plaything.

The whole of the following day (Wednesday) was occupied in showing the capabilities of the steamer to the Port-Admiral and to the naval officers who went on board.

The Thames left Plymouth at noon on Thursday for Portsmouth, where she arrived at 11 o'clock on Friday morning, having steamed 155 miles in twenty-three hours.

At Ports- 
mouth she created a greater sensation than at any of the ports she had visited. 'Tens of thousands of spectators assembled to gaze at her; and the number of vessels that crowded around her was so great, that it became necessary to request the PortAlmiral to assign the voyagers a guard, in order to preserve some degree of order. The Trames steamed into the harbour in the most brilliant style, travelling with the aid of wind and tide at the rate of between twelve and fourteen knots an hour. $A$ court-martial was sitting at the time on board the GLAnciron frigate, but the novelty of the steam-boat presented an irresistible attraction, and the whole court went off to her (except the president). At an early how next morning (Saturday), the Port-Admiral, Nir Edward 'Thornborough, sent his band and a guard of marines on board, and soon afterwards followed in person, accompanied by three admirals, eighteen post-captains, and a large number of ladies. The morning was spent very pleasantly in steaming amongst the fleet, and rumning over to the Isle of IVight. The Admiral, and all the naval officers, expressed themselves delighted with the 'THass.

From Portsmouth the steamer proceeded to Margate, which was reached on Sunday morning. She remained at Margate until the following day, when she started on the final portion of her voyage at half-past eight in the morning, and reached her destination (Limehouse), about six o'clock the same evening, having accomplished the ninety miles run from Margate in about nine hours. The Thames carried fifteen tons of coal, her consumption being, on the average, a ton for every hundred miles. So ended this memorable voyage, practically the first ever attempted by a steamboat on the open sea.

Dodd's after career was a most melancholy one. Talented, enterprising and courageous though he undoubtedly was, yet he never succeeded in his enterprises. And in his later years, instead of seeking that divine help which would have enabled him to meet his disappointments with fortitude, he sought to forget them in intemperance, and almost literally died a beggar in the streets. 


\section{Chapter V.}

1816 to 1818. - Rivals to the Thanes, the Defiance (1815), Majestic and Regent (1816).-Loss of the Regent (1817).-Liverpool Steam-boats: the Runcons Packet, the Princess Challotte, Liverpool to Eastham (18i6). Regclator and Etna, Liverpool to Tranmere (1817).--Parkgate to Bagillt, N.W., the Axcient Briton (1817).-First Spanish Steamer, Royal Ferdinand (1817). - Siberian Steam-boats (1817). - Loss of the Regillator (1818).-David Napier.-Greenock and Belfast Steamer, Roв Ror.-First Steamer between England and Ireland, the Hibeiria (1816).

The successful voyage from the Clyde to the Thames achieved by Captain Dodd, and the less-known one by the Runcorn Packet from the Clyde to the Mersey, gave a great impetus to steam-packet building, and created active opposition, especially on the London and Margate service. The 'lнамеs, after being refitted, opened the service in July, 1815. She had a monopoly of the station for about three months, when the Defraxce was put on in opposition. The following year saw the MAstste placed on the Rivei Thames, and this vessel was probably the first steamer employed in towing ships. She towed, on Wednesday, 28 th August, 1816, the large Indiaman, the Hope, from Deptford to Weolwich at the rate of three miles per hour against the wind.

On the 29th .June of the same year, a new steamboat, named the Recilst, was tried on the Thames. She was built under the supervision of the eminent engineer Brunel, by Maudsley (founder of the famous engineering firm of Maudsley and Field). Her burden was 112 tons, and she was propelled by engines of 24 horse power. On her trial trip she steamed from Blackfriars Bridge to Battersea Bridge in 30 minutes, and back through London Bridge in 52 minutes. Her machinery was remarkably light. Her engines, paddle-wheels, and all 
connections necessary to give and convey the motive power. weighing only five tons. The REgkxt had a very short existence. On the 2nd July, 181\%, she left London for Margate, with between 40 and 50 passengers on board. Although it was blowing a gale, all went well until the vessel arrived off Whitstable, about 18 miles from Margate. The Regrent was keeping well out in mid-channel, and was about three miles from land, when she was discovered to be on fire amidships. The force of the wind had carried away the funnel, and the wood-work at the bottom of the funnel (nearly breast high from the deck for the protection of the passengers), caught fire. The vessel's life-saving equipment consisted of one small boat, barely sufficient to accommodate her crew; and the only available means of extinguishing the fire was by hand buckets, dipped overside. To add to the alarm of the passengers, the buckets one after the other were either broken against the side of the steamer, or carried away by the turbulent waves. The passengers bore themselves bravely, as Britons should in the face of danger, and did not give way to panic. Perfect dis(ipline appears to have been maintained amongst the crew. Seeing that he had no means of keeping the fire under, the Captain collected all the passengers forward and headed the REGENT for the nearest shore with the intention of beaching her. This he succeeded in doing without the loss of a single life, but the vessel herself was almost totally destroyed.

On the Mersey, also, progress had been made since the arrival of the first steamer, the Packet, to and from Runcorn.

In July, 1816, the steam-packet Prixcess Chardotte commenced the Liverpool and Eastham service, and continued to sail twice each way daily. The fare charged to Eastham and back was 1s. At Eastham the steamer connected with coaches to and from Chester, Shrewsbury, Holyhead, and many other places.

The Liverpool and Tranmere Steam Ferry was opened by the steam-packet “Etna” sailing from the West-side Queen's Dock. She was shortly afterwards opposed by the steampacket Regulator, rumning in connection with coaches from Tranmere to Parkgate, thence by stếam-packet Axciext Britox 



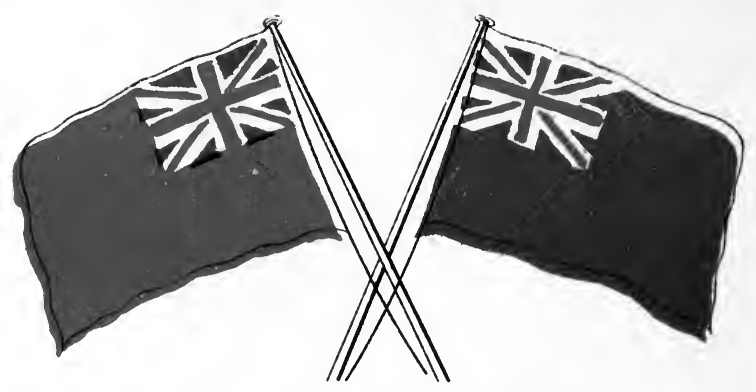

INTERNATIONAL CODE FLAGS.
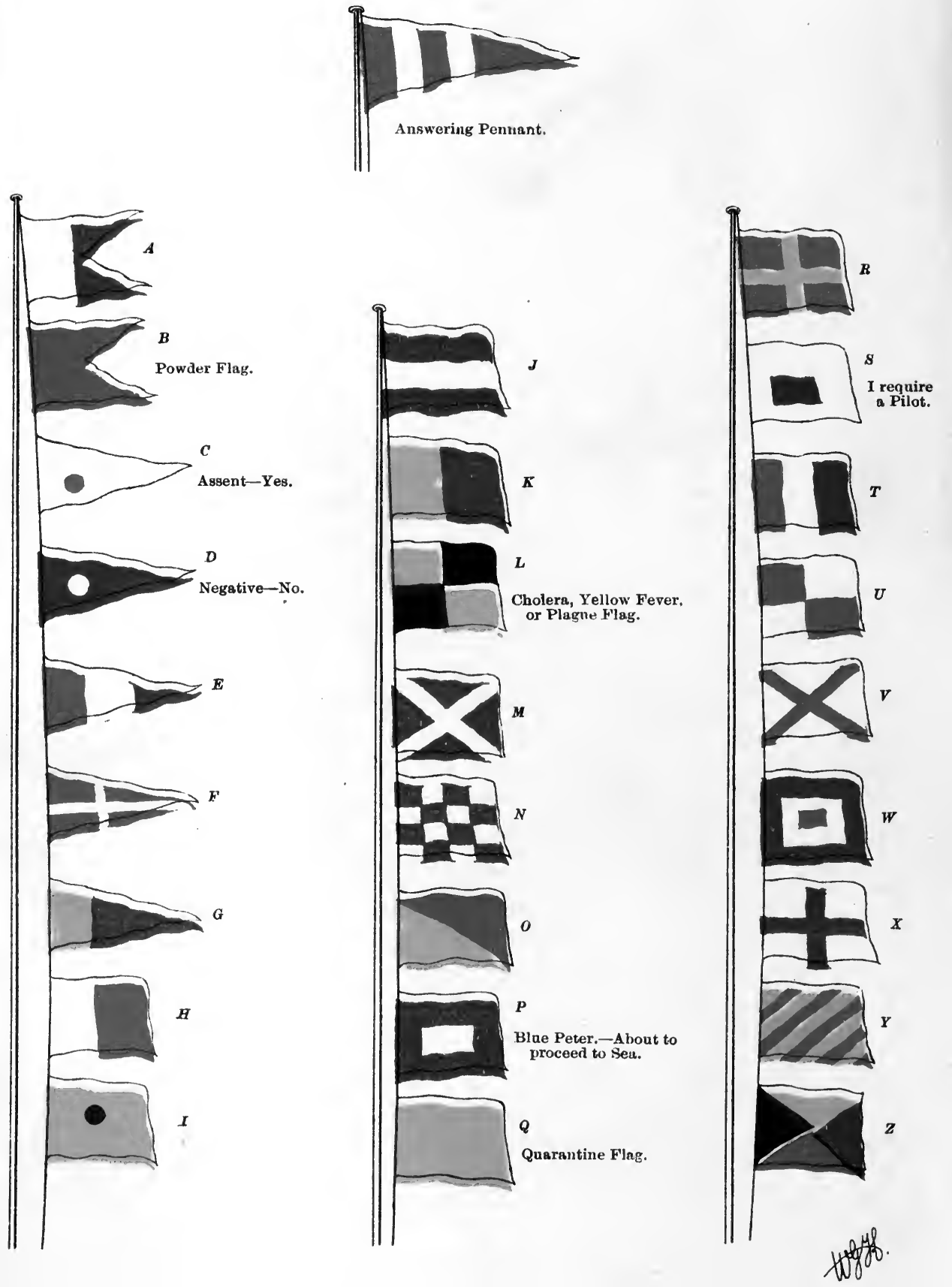

to Bagillt, North Wales. During a gale on Monday, 12th January, 1818, the Reiclatron was sunk near the Liverpool Pierhead, but all on board were resened.

Meantime other continental nations were awakening to the advantages of steam navigation.

On the 30th May, 181i, there was launched at seville the Royal Ferdinand, the first steamer built in spain. And, about the same date, Mr. Wesewelodsky, a man of great wealth, and owner of several rich mines in Siberia, built two steamer's for navigating the River Kama. These vessels were 51 feet and 100 feet long, respectively. Mr. Wesewelodsky travelled with his steamers from his mines to Casan, a distance of 1,000 versts, and accomplished the voyage in 105 hours.

* " England owes to David Napier the establishment of " deep-sea communication by steam-vessels, and of Post Office "steam-packets. As a first step, he endeavoured to ascertain " the difficulties to be encountered. For this purpose he took " passage at a stormy period of the year on a sailing packet, " which formed one of a line, and the only means of inter" course between Glasgow and Belfast; a passage which often " required seven days to accomplish what is now done by steam " in as many hours. The captain of the packet found a young " man, whom he afterwards knew as Mr. Napier, during one of " his winter passages to Belfast, constantly perched on the bow "of the vessel, fixing an intent gaze on the sea when it broke " on the side of the ship, quite heedless of the waves and spray "that washed over him. He only ceased from this oceupation " at intervals, as the breeze freshened, to ask the captain " whether the sea was such that it might be considered a rough " one, and, when told that it was by no means unusually rough, " he returned to the bow of the vessel and resumed his study" "of the wares breaking at her stem. When the breeze began " to freshen into a gale, and the sea to rise considerably, he "again enquired of the captain whether the sea might now be " considered a rough one, and was told that as yet it could not " be called very rough. Disappointed, he returned again to "his station at the bow, and resumed his employment. At 
"last he was favoured with a storm to his contentment, and " when the seas, breaking over the vessel, swept her from stem "to stern, he found his way back to the captain and repeated " his encuiry, "Do you call it rough now?' The captain "replied he could not remember having faced a worse night " in the whole of his experience, a reply which delighted "young Napier, who muttering, as he turned away, 'I think " I can manage if that is all,' went down to his cabin. Napier " saw then the end of his difficulties, and soon satisfied himself "as to the means of overeoming them. If is next enquiry was "as to the means of getting through the water with least "resistance. I'o determine this, he commenced a series of " experiments with models of vessels in a snall tank of water, "and soon found that the round full bluff bow adopted for " sailing vessels was quite unsuited for speed with mechanical "propulsion of a different nature. This led him to adopt the "fine werlge-like bows by which the vessels built under his " superintendence were afterwards so distinguished."

Napier established regular steam-packet communication between Greenock and Belfast by means of the Ros Ror, a vessel of 90 tons burden and 30 horse power. After plying for two years between these ports with great regularity and suecess, the lion Rox was transferred to the English Channel as a packet between Dover and Calais. Cross-channel steamboats between England and Ireland were first introduced in 1816, when the steam-packet Hobersia was built by a company to carry passengers between Ilolyhead and Howth. The Ilnzersia was 11: tons burden, if feet keel measurement, and 9 feet draft. She was lugger rigged, and capable of making the passage by sails only. Her average passage, Holyhead to Ilowth, was about seven hours, and her passengers frequently had the satisfaction of arriving in Dublin considerably in advance of the Mail packets.

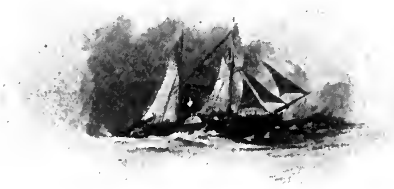


Chapter vi.

Early Clyde Steam-packets.-Season Tickets issued, 1816.-First steamer to cross the English Chamel.-Dunbah'on Castle steams round North of Scotland, 1819.-First serious Accident to a Steam-packet.-Clyde Passenger Fares, 1818.

Many circumstances combined to make the clycle the birthplace and the home of the Marine Steam lingine. C'oal and iron mines were in close proximity, and skilled labour for the construction of engines and of ships was abundant. The beautiful Firth, with its numerous lochs and islands, constituted an ideal locality for the employment of steamboats while yet the art of steamship building was in its infancy. And on the shores of the River, or within easy distance of it, dwelt a large industrial population, eager to take advantage of the farcilities for travel which steamboats aftorded.

Under these circumstances it is not surprising that steampackets on the Clycle increased with marvellous rapidity. In 1812 the Comer first began to ply between Glasgow, Greenock and Helensburgh, and she was, in fact, the only steamboat then sailing on British waters. Three years later (in 1815) a fleet of seven steamers, vi\%, the Ghasiow, Britasia, Dumbartos Castle, Calemona, Argifle, Prince of Oraxge, and Prackess CinnRotre, sailed regularly from Glasgow to Largs, Ardrossan, Troon and Ayr, southwards; and Rothesay, Tarbert, Lochgilphead and Inverary, westwards. No agents' names are given in any of the press advertisements of this or previous years, but 


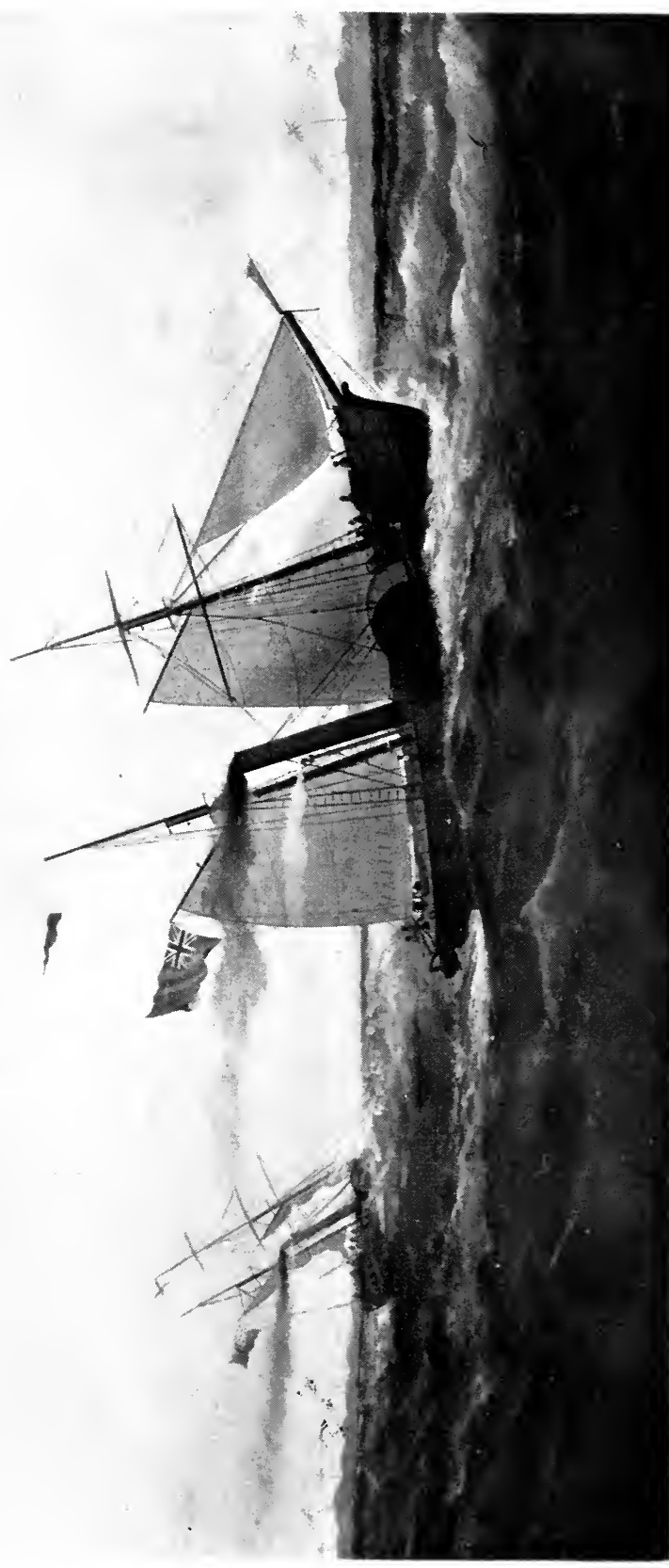

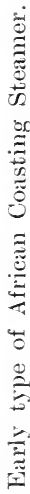


the sailings were advertised on boards placed outside the agent's counting houses, and exhibited in taverns and other places of public resort. In 1816 and subsequent years the owners' or agents' names are appended to the press notices of the various steam-packets.

In May of the year named, the steamboats Britaxida and (new) Waterioo were advertised to sail between Glasgow and all the watering places on both sides of the Clyde.

"Families wishing to agree for the season may know " particulars by applying to Mr. Lewis MacLellan, Gallow-

"gate, Mr. Wm. Smith, Bromielaw, and the Masters on "board."

These small steamers were the pioneers of the magnificent fleet of Channel steamships, sailing from Glasgow, and known as the "Laird Line." A grandson of the Mr. Lewis MacLellan here referred to, and a nephew, are still (1903) connected with the Company as directors. 'The steamer AlBıox was advertised in the same paper in similar terms, and on the 9th July following the agents of nine steam-packets sailing from Glasgow, gave notice that the issue of season tickets was discontinued for the remainder of the season.

Hence it appears that the issue of season contract tickets, popularly supposed to be a modern institution of the railway companies, is found to be a common practice amongst the steamship owners of Glasgow more than three-quarters of a century ago.

Mr. W. S. Lindsay, in his admirable book " The History of Merchant Shipping from 1816 to 18r4," quotes Mr. Muirhead's "Life of Watt," as stating that "In April, 1817, Mr. James Watt, Jun., purchased the Caledoxia, and having re-fitted her, took her in October to Holland and up the Rhine to Coblent; ; having thus been the first to cross the English Channel in a steamboat. The average speed he obtained was seven and a half knots an hour.",

Either Mr. Muirhead was in error in the dates given, or he was wrong in assuming that the Calsmoxis was the first steamer to cross the Euglish C'hamnel. A correspondent of the "Glasgow Chronicle," in a letter to that Journal, dated Cologne, 
16th June, 1816 (i.e., sixteen months prior to the date mentioned by Mr. Muirhead as the date on which the Calmonia crossed the Chammel), says :-

"To-day, about noon, we enjoyed a sight equally novel " and entertaining, a pretty large vessel without a mast " ascending the Rhine, and proceeding with astonishing "rapidity, arrive before this city. All the vessels "stationed on the Rhine in this neighbourhood were in " a moment covered with spectators, to see the arrival of "this vessel, which is a steamboat coming from London, " and bound for Frankfort. Everyborly was eager to view "the progress, the motion, the organisation of this master"piece of art. The ressel left Rotterdam on the 6th " inst. The passengers affirm that it can go 25 leagues in "a day."

The Dumbarton Castie (Captain Thomson) was advertised to take passengers for a trip from Glasgow round Ailsa Craig on the th August, 1816. She was the first British steamboat (the THames excepted) to take passengers on a deep sea trip, and she was also the first steamer to sail round the North of Scotland, which she did in 1819, in consequence of being sold for employment between Leith and Grangemouth.

The first serious accident to a Clyde steamboat of which there is any record, occurred in the early part of the year 1816 . The new steam-packet Rotumsay Castus, while entering the harbour of Tarbert on her return voyage from Inverary, struck on a reef of sunken rocks. All her passengers were rescued by fishing boats, which also landed the luggage. One of the fishing boats was also despatched to request the Master of the Argice (which was to leave Inverary four hours later than the Rothesay (Astie) to call at Tarbert. This was accordingly done and the shipwrecked passengers were taken on to Rothesay and Greenock the same evening. The steamer was subsequently got off the rocks and taken to Port Glasgow for repairs.

It may interest citizens of Glasgow and dwellers on the coast to compare, by means of the following table, the steamship Passenger Fares of 1818 with those of the present day. 


\begin{tabular}{|c|c|c|c|c|c|c|c|c|c|c|c|c|}
\hline To & Ren & frew. & Dur & glass. & $\begin{array}{l}\text { Gla } \\
\text { Gre }\end{array}$ & $\begin{array}{l}\text { ort } \\
\text { gow or } \\
\text { nock. }\end{array}$ & Gor & rock. & & args. & Mil & lport. \\
\hline From. & تี & 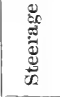 & हี & 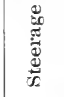 & تี & 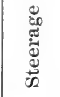 & تี & 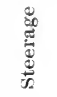 & 苂 & 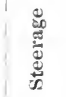 & כુ & 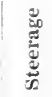 \\
\hline Glasgow & $\begin{array}{lr}\text { s. } \\
1 & 0\end{array}$ & $\begin{array}{ll}\text { s. } & d . \\
1 & 0\end{array}$ & $\begin{array}{cc}\text { s. } \\
2 & 0\end{array}$ & $\begin{array}{cc}\text { s. } & \text { d. } \\
1 & 6\end{array}$ & $\begin{array}{ll}\text { s. } & 0 \\
4 & 0\end{array}$ & $\begin{array}{ll}\text { s. } & d \\
2 & 6\end{array}$ & $\begin{array}{ll}\text { s. } & \text {. } \\
4 & 0\end{array}$ & $\begin{array}{ll}\text { s. d. } \\
3 & 0\end{array}$ & s. $\begin{array}{c}\text { s. } \\
7\end{array}$ & $\begin{array}{cc}\text { s. } & \text { d. } \\
5 & 0\end{array}$ & s. $\frac{d}{6}$ & $\begin{array}{cc}\text { s. } & d \\
6 & 0\end{array}$ \\
\hline Greenock. . & $\begin{array}{ll}3 & 0\end{array}$ & 20 & 20 & 16 & . & . & 10 & $\begin{array}{ll}0 & 6\end{array}$ & 36 & 26 & 46 & 36 \\
\hline Largs $\ldots$ & $\begin{array}{ll}6 & 6\end{array}$ & 40 & 56 & 36 & $\begin{array}{ll}3 & 6\end{array}$ & 2 ; & $\begin{array}{ll}3 & 0\end{array}$ & 20 & .. & .. & 10 & 10 \\
\hline Ardrossan & $\begin{array}{ll}9 & 0\end{array}$ & $\begin{array}{ll}6 & 6\end{array}$ & 80 & 60 & $\begin{array}{ll}6 & 0\end{array}$ & 50 & 56 & 46 & 26 & 20 & 16 & 10 \\
\hline Rothesay ... & . & . & . & . & . & .. & .. & $\therefore$ & .. & .. & . & .. \\
\hline
\end{tabular}

\begin{tabular}{|c|c|c|c|c|c|c|c|c|c|c|c|c|}
\hline \multirow{2}{*}{ From. } & \multicolumn{2}{|c|}{ Rothesay. } & \multicolumn{2}{|c|}{ Ardrossan. } & \multicolumn{2}{|c|}{ Troon. } & \multicolumn{2}{|c|}{ Ayr. } & \multicolumn{2}{|c|}{ Helensburg. } & \multicolumn{2}{|c|}{$\begin{array}{c}\text { Campbelton } \\
\text { or } \\
\text { Inverary. }\end{array}$} \\
\hline & تే & 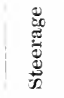 & 苛 & 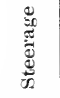 & 芯 & 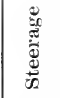 & ప艹 & 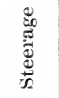 & : & 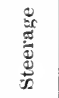 & שี & 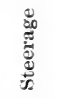 \\
\hline Glasgow & $\begin{array}{lr} \\
7 & d .\end{array}$ & $\begin{array}{cc}\text { s. } & \text { d. } \\
5 & 0\end{array}$ & $\begin{array}{ll}\text { s. } & \text { d. } \\
10 & 0\end{array}$ & s. & s. & s. $\begin{array}{l}\text { s. } \\
8\end{array}$ & s. $\begin{array}{c}\text { a. } \\
12\end{array}$ & $\begin{array}{cc}\text { s. } & \text { d. } \\
9 & 6\end{array}$ & s. $d_{4}$ & $\begin{array}{cc}\text { s. } & \text { d. } \\
3 & 0\end{array}$ & $\begin{array}{rr}\mathrm{s.} & \mathrm{d} . \\
12 & 0\end{array}$ & $\begin{array}{ll}\text { s. } & \text { d. } \\
8 & 6\end{array}$ \\
\hline Greenock... & 36 & 26 & $\begin{array}{ll}6 & 0\end{array}$ & 50 & 70 & $\begin{array}{ll}6 & 0\end{array}$ & 80 & 66 & 10 & 10 & 90 & $\begin{array}{ll}6 & 6\end{array}$ \\
\hline Largs ... & 16 & 10 & $\begin{array}{ll}2 & 6\end{array}$ & 20 & 36 & 26 & $4 \quad 6$ & 36 & . & . & .. & . \\
\hline Ardrossan & . & .. & .. & . & 16 & 10 & 26 & 20 & .. & .. & .. & .. \\
\hline Rothesay .... & .. & .. & .. & .. & .. & .. & .. & .. & .. & .. & 76 & $\begin{array}{ll}5 & 0\end{array}$ \\
\hline
\end{tabular}

Young persons 8 to 14 years of age-half-price. Below eight years of age at the discretion of the Master.

These rates were fixed by a ('onference consisting of the proprietors of the following steamboats:-Alsiox, Argirf,

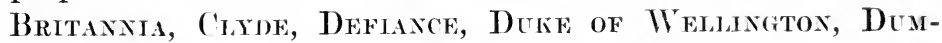
martox (astlat, Glasiow, Margaret, Marquas of Bute, Neptuafe, Prixce of (Oraxge, Rothesar Castefe, and WatrRLoo, who agreed that the Fares taken from passengers travelling by any of the boats named should be according to the above table, and that no engagements should be entered into with families or individuals at rates below these fares. Passengers were allowed 28 lbs. of luggage free, exeess luggage was charged at the rate of $10 \mathrm{~d}$. per cwt. from Glasgow to Greenock, and proportionately for any further distance. 
Chapter VII.

1819 to 1821 . - The Savannah the first steamer to cross the Atlantic.-Arrival at Liverpool of the WATERLOo, the first Irish Channel steamer.-Sailing of the RoBErT BRUCE, the first steamer trading between Liverpool and the Clyde.-Curious Accident to the steamer Morning Star.-The Triton.The Conde de Patmella, first European steamer to cross the Atlantic.Cattle Ventilators suggested.-The TourisT.--Steamers between London and Leith.

PrIor to the introduction of marine steam engines, the United States of America had no inconsiderable share of the world's ocean traffic. No swifter ships raced with cargoes of tea from China to the Thames than the famous Baltimore elippers. No finer vessels crossed the Atlantic than the celebrated New York Packet Liners. It cannot be supposed that a people so enterprising as the Americans would make no attempt at ocean steam navigation. On the contrary, as they were the first to build a coasting passenger steamer, so were they the first to build a steamer to cross the Atlantic.

1)uring the latter part of the year 1818, and the beginning of 1819, there was, in process of building at New York, a beautiful little ship of about 320 tons burden. Whilst on the stocks it was suggested to convert her into a steamer, which was accordingly done. After she was launched, the SavasxaH, that being the name given to her, sailed from New York to Savannah, and thence, about the 25th May, 1819, she sailed to Liverpool, en route to St. Petersburg. It was reported at the time that she was a present from the Americans to the Emperor of Russia. Although she did not steam the whole of the voyage from Savannah to Liverpool, which oceupied twentysix days, she was the first steamer that ever attempted to cross the Atlantic. British and Canadian authors have contended that she was not entitled to this honour, as her steam power 
was merely auxiliary, but the contention is somewhat ungenerous, and, if allowed, would debar later vessels, notably the Saran Sands and the Great Britaix, from claiming the title of steamships. The Savarvan reached Liverpool on Sunday, 20th .June, 1819, after a voyage of twenty-six days duration. Shortly after leaving Savannab it began to blow hard, and the following entry appears in the ('aptain's log book:

"Stopped the engines, and brought the paddle-wheels "in-board in thirty minutes."

When off the Irish coast, the coastguard, seeing a huge volume of smoke proceeding from a ship at sea, reported it to be a vessel on fire. A Government cutter from Cork put out to render assistance, and were much surprised on boarding her to learn that she required no assistance, exrept a Channel pilot, and that she had come from America. Her arrival at Liverpool was witnessed by great crowds of people, who had assembled to watch her entering the Mersey. After her visit to St. Petersburg she re-crossed the Atlantic, her engines were taken out of her, and, as a sailing packet, she traded between New York and Saramnah, until she was wrecked off Long Island.

A month later, or to be exact, on the 22nd July, 1819, the first cross-channel steamer that ever entered the port, arrived at Liverpool from Belfast, after a passage of twenty-four hours. This steamer was the WATERIoo, owned by Messrs. Langtry, of Belfast, who were also the owners of a fleet of smarks which traded regularly between the two ports. The Waterioo was a schooner-rigged parlde-steamer of 201 tons burthen, propelled by a pair of low-pressure engines of $3(0 \mathrm{~h} . p$. each. Her length was 98 feet, and her breadth on deck was 37 feet. She had a dining room capable of accommodating all the cabin passengers at one sitting, a separate and neatly decorated cabin for ladies, and two state-rooms for families. She carried sleeping accommodation for 22 rabin passengers, in addition to steerage passengers. The fares charged for a single passage between Liverpool and Belfast were, cabin $£ 111$ s. firl., steerage 10s. Gid. The Watwroo made two round voyages per week 
during the season, sailing from Liverpool every Monday and Friday. She was intended to carry passengers only (the cargo trade being maintained by the smacks), and cost her owners nearly $£ 10,000$.

On the 29th July of the same year, the first steamer that traded between Liverpool and Glasgow was advertised in the following terms :-

"Safe and Expeditious Travelling between Liverpool " and Glasgow.

"The elegant new Steam-Packet Boat,

"Robert Bruce,

"Captain John Patterson,

“will sail for Glasgow on Monday, 2nd August, at Seven "o'clock in the morning, from George's Dock, Pierhead.

"The accommodations for passengers are most excellent, "and she is expected to perform the passage within 30 " hours.

"The Fares in the Cabin, 40s.; Steerage, 21s. Pas"sengers will be accommodated with Provisions on "moderate terms. For passage apply to Captain

"Patterson, or to

"John Richardson."

From this date (1819) the expansion of the British steam coasting trade was most rapid. Within a very short time regular services were advertised between Liverpool and Isle of Man, Whitehaven, Dumfries, the Clyde Ports, Belfast and Dublin. Nor were these pioneers of the steam trade permitted to be monopolists of their respective stations. Frequently two, and in some cases three companies advertised steamers sailing for the same ports, of which some account will be found in the succeeding chapters of this volume.

An extraordinary accident is reported by the "Berwick Advertiser" (September, 1819), as having occurred to one of the local steam-packets. The Morning Star, while on her usual passage from Alloa to Leith, suddenly stopped. On investigation it was discovered that a salmon had entered and completely obstructed the condensing water pipes, and thus stopped the machinery. 
In the fall of the following year (1820) steam communication between the Ports of London and Hull was projected.

Across the Channel the steam-packet Tritos, built at Bordeaux, maintained a passenger service, three times each way per week, between IIavre and Rouen. The passage occupied about nine hours, and the fares charged were 8 s. first elass, and $4 \mathrm{~s}$. second class.

On the 5th October, 1820, the steamer Covin ne Patmelici, Captain Silva, sailed from Liverpool for the Brarils. She made a remarkably rapid passage to Lisbon, arriving there in four days. This is probably the first steamer that ever crossed the Atlantic Ocean from Europe.

Perhaps one of the most remarkable steamers ever launched was a small steamboat, named the SxAKE, built at Bombay, and launched in 1820. She was the first steamer on the Indus or on any river in India. Her engines were designed and built by a Parsee, and were the first ever manufactured in India. How well they were constructed is evidenced by their lasting power. After a notable career of 60 years, she was broken up in 1880 .

Above the initials " W. P.," a correspondent of the " Liverpool Mercury," in a letter dated 25th October, 1820, suggests the use of iron ventilators, to supply fresh air to the holds of steamers carrying cattle across the Channel, for, of course, at that date, steamers to carry cattle across the ocean were unthought of. He describes the ventilators suggested as "iron funnels with movable vane tops, which could be constructed by any mechanic at a cost of about $£ 310$ s. each."

In the spring of 1821, a new steamboat, named the Tourist, was launched at Perth. When launched she was the largest steamer in the United Kingdom, being 128 feet long by 40 feet broad. She was rigged as a three-masted schooner, with a clipper bow and bowsprit, and was propelled by two engines of 40 h.p. each. She was intended (as her name implies) for the passenger trade between Leith and the Northern Ports of Scotland, and her owners claimed that communication between the ports named "will thus be effected in one-third less time, and for one-sixth of the expense incurred by the present mode 
of travelling." After running for a short time in the Leith and North of Scotland trade, she was placed on the station between Newhaven and London, on behalf of the London and Edinburgh Steampacket Co.

In May of the same year two steam vessels of upwards of 400 tons burden each, were built for the Leith and London passenger service. These steamers were not intended to carry cargo, but they had sleeping accommodation for one hundred passengers. They were propelled by engines of $100 \mathrm{~h} . p$., and were expected to make the passage in about sixty hours. 


\section{C'inpter VIII.}

St. George Steam-Packet Co. incorporated, 1822,- Swift passage of the Hkro, steam yacht.-Liverpool owned steamers highly commended in Parliamentary Report, 1822.-AAron MANBY, iron steamer.-First steamer between Hull and the Continent, 1823.-City of Dublin Steam-Packet Co. founded, 1823.-H.MI.S. Lightning.-General Stem-Packet Co. and the Belfast Steam-Packet Co. established, 1824.-Keen competition, Glasgow and Belfast service, 1825.-Adrertising extraordinary.-C (. \& \& J. Burns commence business, 1825, as steamship owners.-Competition on the Liverpool and Dublin station.-First steamer from the Thames to Hamburg.--The Enterprize sails for Calcutta.-Rapid growth of Steam Navigation.-Dailing ship owners petition Parliament, 1826. - The Ens. - Liverpool and Kingstown Royal Mail Service.-City of Dublin Steam Packet Co. establish a Passenger Service between England, Ireland and France, 1827.

THE year 1822, witnessed the first operations of what was destined to become one of the most famous of the early SteamPacket Companies. Projected the previous year, the St. George Steam-Packet Company immediately contracted with Mr. Thomas Wilson, of Liverpool, for two large and powerful steamers, the S'T. PAtrick and the S'T. Georik. The former was intended to trade between Dublin and Liverpool, and Dublin and the Bristol ('hannel; and the latter between Liverpool, the Isle of Man, and the River Clyde, Mr. Alex. A. Laird, the founder of the well-known firm of Alex. A. Laird \& Co., being the agent at Greenock. The St. PAтricr was launched at 10-30 a.m. on the 21st April, 1822. This event excited great interest in the town of Liverpool, as she was, if not the first steamer ever built in the port, certainly the finest specimen of the ship-building craft produced there up to that date. Her sister ship, the ST. Gkonge, launched the following day, rapidly won for herself a reputation for comfort and speed. After ruming about six months she made a royage from Dublin to Liverpool in $11 \frac{1}{2}$ hours, the shortest time on record. Eighteen months later she made a passage from Liverpool to Dublin in 10 hours 40 minutes, beating her previous record by 50 minutes. The third steamer was the Prixce Lifweldyx, to ply between Liverpool, Beaumaris, Bangor, and Carnarvon. 


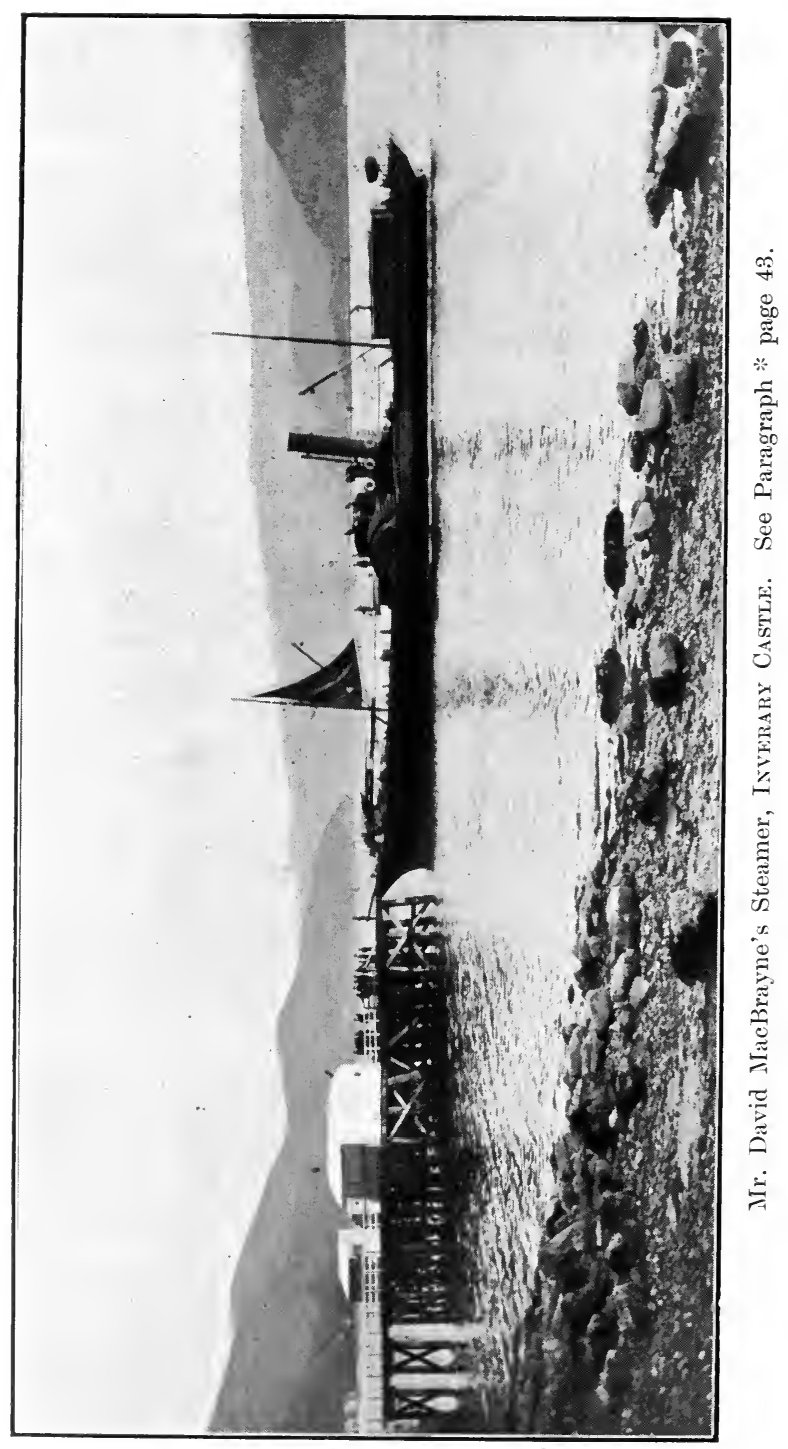


The St. George Steam-Packet Co. continued until 1844, when it was re-constructed, the Cork Steamship Co. taking over its various services and seven of its steamers.

The steam-yacht Hrro is credited with a phenomenal speedy voyage on the 26th July, 1822. She is reported to have steamed from London to Margate in $6 \frac{1}{2}$ hours, being at the rate of 14 miles an hour.

A report relative to steam navigation was laid before the House of Commons (August, 1822). All the steam-packets belonging to Liverpool were named in a manner highly honourable to their owners, commanders and constructors.

"On Thursday, 9th May, 1822, a large party of " distinguished naval officers, engineers, \&c., embarked at " Parliament Stairs, London, on board the Aarox Manbr, " iron steamboat, which immediately got under weigh and " proceeded to Battersea Bridge; she then descended to "Blackfriars, and manœuvred for several hours between " the two bridges in a very superior style. This steamboat " was built at the Horsley Iron Works, near Birmingham, "by Mr. Manby, and put together at Rotherhithe. She is " the most complete specimen of workmanship in the iron " way that has ever been witnessed, and draws one foot less " water than any steamboat that has ever been built. She " is 106 feet long and 17 feet broad, and is propelled by a “30 h.p. engine and Oldham's revolving bars. This boat "will leave London in a few days for Paris, the first " instance of a direct communication between the capitals " of France and England. Amongst the gentlemen “present were Admirals Sir William Hope, Sir Pulteny "Malcomb and Sir James Wood Gage; Captains Dundas " and Napier" Mr. Manby, the inventor" Mr. Williams, "the patentee of the revolving bars, \&c."- "London Courier," 15th May, 1822.

On or about the 24th March, 1823, the steam-packet Yorkshiremax arrived at Hull from Antwerp, and was only 31 hours on the passage. This vessel is noteworthy as being the first steam vessel to sail from Hull to the Continent.

In the month of February of this year (1823) Mr. C. W. 
Williams, of Dublin, placed an order with Mr. Wilson, of Liverpool, for the pioneer steamer of the future famous City of Dublin Steam-Packet Company, the City of Dubin, a vessel of 130 h.p. It was an express stipulation with the builder, that this steamer should be constructed of such materials, and in such a manner, as to withstand the severity of the winter navigation. The Citr of Dublin differed from her competitors in two respects, (1) in carrying general cargo in addition to live stock and passengers, and (2) in maintaining the service uninterruptedly throughout the twelve months.

A month later, Mr. Wilson was again applied to, to build a second vessel for the company, but in consequence of his having that very morning (5th Mareh, 182:3) contracted to build the steam-packet Hexry BeLL for the Liverpool and Glasgow trade, it was not till some days later the contract was signed for building the Tow of Liverpoor, to be commenced as soon as the HENRY BELL was launehed.

The City of Dubsis sailed from Dublin on her maiden voyage to Liverpool on Saturday, the 20th March, 182t. She anticipated, by about six months, the operations of the Dublin and Liverpool Steam Navigation Co., whose first steamer, the Lifrex, 305 tons burthen, and 110 h.p., did not sail until the 13th September following. In December of the same year (1824) the Merser joined the LrFfer, and in the July following the Commerce was added to the Navigation Co.'s fleet. The Commerce was considerably larger than either of her predecessors, and was launched from the yard of Messrs. Grayson and Leadley, Trentham Street, Liverpool.

Her (late) Majesty's steamship Lightrixg sailed from Algiers for home on the 2rth .July, 182t, calling at Gibraltar and Lisbon. She remained at Lisbon two days taking in coal, and finally arrived at Plymouth nineteen days after leaving Algiers. The Ligintixic was one of the first vessels in the British Navy to be supplied with steam power.

Two still existing and influential Steamship Companies were established this year. The General Steam Navigation Co., of London, and the Belfast Steam-Packet Co., afterwards merged into the Belfast Steamship Co., Limited, of Belfast. 
The competition between the Steans-Packet Companies engaged in the Sootch and North of Ireland passenger trade harl become so keen, that in the summer of 18:5 the steamed's from Belfast to Glasgow lowered their fares to '2s. for 1st cabin, (id. for '2nd cabin, and carried deck passengers for nothing.

On the Dublin and Liverpool station competition was nearly as severe, one steamer sailing in the autumn of 18\%; with upwards of 700 passenger's rarried at fid. each.

Under these adverse circumstances, the proprictors of the Dublin and Livërpool Steam Navigation ('o. deemed it prudent to make terms with their more powertul competitor, the City of Iublin Steam-Packet Co. The managers of the latter' company, early in the following year (1st February, 18:60), purchased the Navigation ('o.'s steamers, and increased the capital of their own company to $£ 250,000$, in shares of $£ 100$ each.

The Press communications exchanged between the owners of the rival steam-packets must have been extremely entertaining to the citizens of Glasgow of that periorl. The following extraordinary literary effusion, from the owners of the steamboat Swrw, was published in the "Glasgow Herald," of the 30th June, 18:5 :

" The great superiority of the Swww over the Coek Boat " that is puffed off' as sailing direet from the Bromielaw " is now so well known at Glasgow and Belfast as scarcely "to require to be noticed in this advertisement, but for " the sake of strangers coming from a distance it may be " proper to state that her power and size are double, and "her speed so much greater, that when the two vessels "start together the SwrF runs the othel out of sight in

" five or six hours. Her hours of sailing are so adapted

"to the tide, as to ensure the shortest possible passage, by

" arriving at Greenock and Glasgow about high water, and "at Belfast as soon as there is water up to the quay."

'The following crushing reply of the owners of the steamer referred to as " the Cock 13oat," appeared in the next issue of the same newspaper.

"The fine new Steam-Packet George Caxsuxg continues 
" to sail for Belfast every Tuesday and Friday. She is

" the only Steam-Packet that sails direct from Glasgow,

" therefore, her passengers are not subjected to the delay,

" inconvenience and risk, attending change of vessel and

" transhipment of luggage.

"The George Canning has crossed the Channel up" wards of 60 times, and has in every instance accomplished " her passage without putting into any intermediate ports. "If the writer of a contemptible article in the SwiFr's "advertisement of Friday last, means the George "Caxring, he has the merit of stating a gross falsehood,

" knowing it to be such; and, therefore, written for the " express purpose of deceiving the public!:!

"The author of the paragraph alluded to is challenged " to produce a single instance of the Swift having ever "accomplished her passage from Belfast in so short a "period as the George Caxping.

"The public will be surprised to learn, after reading the "SwIFT's advertisement, particularly 'strangers coming " from a distance,' that the SwifT and the Canvisg have " never yet sailed together either from Belfast or Glasgow;

"therefore, the author of the SwiFt's advertisement is

"left to state when and where the Swirt ran the vessel " alluded to out of sight."

The rivalry between these two steamers terminated the following year, when the SwrF was sold to the London, Leith and Edinburgh Shipping Company, and sailed for Leith, via Oban, Fort William and Inverness, on the 2ith June, 1826. The George Caxnixg was offered for sale by auction in .June, 18:31, but was evidently withdrawn. She appears to have been sold subsequently by private treaty, and sailed, after repairs, for St. Malo, Brittany, in June, 1833.

The well-known firm, G. \& J. Burns, of Glasgow, commenced business as steamship owners in 1825. The style of the firm at that time was James and George Burns, and their offices were at 45 , Miller Street, but in February, 1842, they changed the style of the firm to G. \& J. Burns.

The first steamer employed by this firm was the new steam- 
packet Arr, of 76 tons, built by John Wood \& Co., of Port Glasgow, and having two engines of 30 h.p. each, by John Nelson, Glasgow. The Arr was employed in the Glasgow and Ayrshire and Galloway trade. On the 20th March following (1826) Messi's. Burns despatched their first steamer from Glasgow to Belfast. She was a new steamboat named FixgaL. Her length was 116 feet, her beam 21 feet 6 inches, and her depth 12 feet 4 inches. She had two engines of 50 h.p. each. She could accommodate thirty passengers with sleeping berths, had several horse boxes on deck, and carried 180 tons of cargo. The rates for passage were, in the cabin, $20 \mathrm{~s}$., and on deck, 3s.; and the days of sailing from Glasgow, 'Tuesdays and Fridays.

Three years later (March, 1829) Messrs. Burns began their Liverpool and Glasgow service. The pioneer steamer of this service was the GLAsGow, a small steamer, 120 tons deadweight, and fitted with two engines of 30 h.p. each. The Messrs. Burns have ceased for many years to have any connection with the Glasgow, Ayr and Galloway trade, but on the other two stations, Belfast and Liverpool, they have maintained continuous services for nearly eighty years. They were also largely interested in the Glasgow and West Highland Passenger Services, but sold their interests in 1851 to Messrs. David Hutcheson \& Co. These services are now conducted by the fleet of splendid steamships owned by the Messrs. MacBrayne of Glasgow.*

On Saturday, the 30th June, 1825, a steam-packet sailed from the Thames for Hamburg, the first that had ever made that voyage.

The following month (16th August) the first steamer sailed from England (Falmouth) to Calcutta, via the Cape. 'This was the wooden paddle-steamer ENTERPRIzk, 470 tons burthen, 120 h.p. Further particulars of this vessel are given in Chapter IX. (Steamship Routes to India and the East).

Some idea of the marvellously rapid growth of steam navigation may be gathered from the fact that in the year 1825, just ten years after the arrival of the first steamers on the Thames and Mersey, there were 44 steam vessels on the stocks at Liverpool of from 250 to 500 tons each; while in London no

* For a special account of this Firm, see Part II. of this Volume. 
less than 45 companies had been formed to establish steampackets in every quarter of the globe. Owners of sailing ships became alarmed for their future, and at a meeting held in Swansea, on the 1tth December, 1826, a resolution was passed to send a petition to the House of Commons, praying for the intervention of Parliament to protect sailing vessels against the further increase of steamers.

Amongst those steamers referred to as building at Liverpool was the Lins, the largest steamer (up to date of launching) ever built in Liverpool. Her principal dimensions were, length 161 feet, breadth 44 feet. Her tonnage was 500 tons gross, and she was propelled by engines of 180 h.p., by Fawcett and Co. She was launched from Mr. Rathbone's yard in February, 1826 , and was intended to trade regularly between London and Belfast, calling at Southampton, Plymouth and Falmouth. Her owners were the Belfast Steam Navigation Co., and she cost $£ 20,000$.

Her (late) Majesty's Steam-Packets, for the conveyance of mails and passengers between Liverpool and Kingstown, commenced sailing on the 29th August, 1826. Captain John Emerson, R.N. (late Commander of the ST. GEorge steampacket), was appointed Captain of one of these Royal Mail Steamers, of which there were four, all built at Liverpool, and each of 300 tons burthen.

The City of Dublin Steam-Packet Company commenced a regular steamship passenger service between England, Ireland and France in June, 1827. The route was from Belfast to Dublin, thence to Bordeaux. Passengers from the North of England were carried by the Company's steamers between Liverpool and Dublin, comnecting at the latter port with the steamer to France. The pioneer steamer of the service was the Llwes, which sailed on her first voyage from Belfast on Sunday, 1rth June, and from Dublin on the following Werlnesday, continuing to sail at fortnightly intervals during the season. The venture was so successful that the Directors of the Company, the following April, added the steamers Shefrield and Nottingham to the service, and increased the sailings to the 1st, 10th and 20th of each month. 


\section{Chapter ix.}

Steamship Routes to India and the East.--Lient. Johnston.-Exтerprize purchased by Indian Government.-Renders important service during Burmese War.-Thomas Waghorn.--Regular steamship service established between Bombay and Suez.-Peninsular Steam Navigation Co. (1834).Altered to Peninsular and Oriental S. N. Co. (1837).-First P. and O. steamer to India, 1842.-Services extended to Ceylon, Penang, Singapore, and Hong Kong, 1844.-And to Australia, 1852.-P. and O. steamships engaged as troopships during Crimean War.--S.S. MIoolTaN (1861) and other later steamers fitted with compound engines.-Suez Canal opened, 1869. Mails transferred to Canal route, 1888.-Calcutta and Burmah S. N. Co. (1855).-Steamers engaged as transports during Indian Mutiny.-Title changed to British India Steam Navigation Co., Ltd. (1862).-Bibby Line.

Soov after steam navigation began to attract attention in Great Britain, a public meeting was held in London (1822), for the purpose of forming a steamship company to trade between England and Inclia. It was the intention of the promoters of the meating that the packets should proceed to India by way of the Cape of Good Hope, the route by which the bulk of the trade of Europe with the East had been carried since the time of Vasco da Gama. At this meeting it was decided that Lieut. (afterwards Captain) Johnston should proceed to Calcutta, with a view to interesting the East India merehants in the proposed undertaking.

Lieut. Johnston proceeded to India rin Egypt, and although he was commissioned to advocate the ('ape route, he was convinced on this journey of the greater advantages of the route by Suez, and afterwards became one of its most ardent supporters. Several meetings were held in Calcutta after his arrival there, at one of whieh, held on the 1ith December, 1823, it was announced that the Governor, Lord Amlierst, cordially approved of the proposal to establish steamship) communication between England and India, and that he was 
prepared to recommend his Council to grant as a premium * " a gift of 20,000 rupees to whoever, whether individuals or "a company, being British subjects, should permanently, "before the end of 1826, establish a steam communication "between England and India, either by the Cape of Good "Hope or the Red Sea, and make two voyages out and two "voyages home, occupying not more than seventy days on " each passage."

An additional 80,000 rupees were raised in India for this object, of which amount the Rajah of Oude subseribed

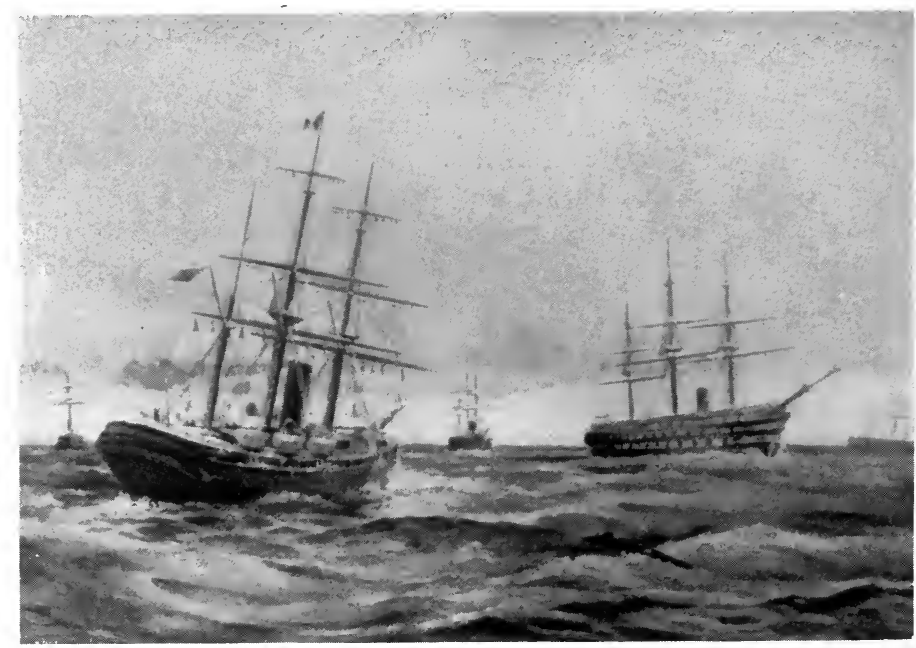

CoLombo carrying Xmas gifts to the troops in the Crimea.

12,000. On receipt of this gratifying news in London, another meeting of those interested was held, at which sufficient capital was underwritten to justify the promoters in ordering, as an experiment, the ExTERPRIze, the first steamer destined to double the Cape of Good Hope.

Johnston, having accomplished his assigned task, embarked on board the Indiaman ELrza for England. On his arrival in London he found the Exterprize two-thirds completed, and on completion he was appointed captain. 
The Enterprize was a paddle-steamer, built of wood, by Messrs. Gordon \& Co., Deptford, at a cost of $£ 43,000$. Her length of keel was 122 feet, beam $2 \tau$ feet, and she registered 479 tons. She had a copper boiler in one piece, which weighed 32 tons, and cost $£ 7,000$. Her engines were 120

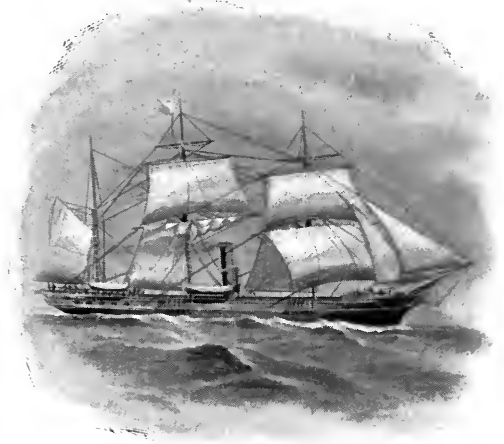

P. \& O. Liner. Date about 1850 A.D.

horse power, capable of propelling her in calm weather at the rate of 8 knots per hour. She sailed with 17 passengers from London for Calcutta on the 16th August, 1825, and arrived at the latter port on the 7 th December following. She occupied 113 days on the passage, partly under steam and partly under sail, and inclusive of ten days stoppages for the

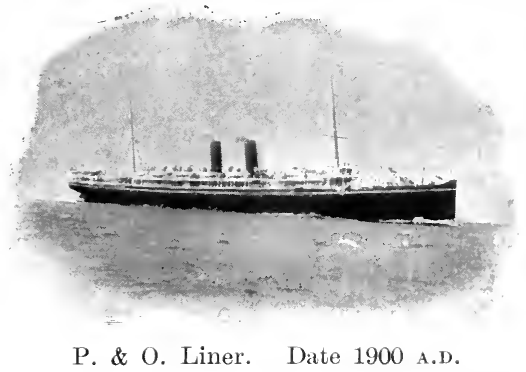

purpose of obtaining fresh supplies of fuel. She did not return to England, but was purchased by the Indian Government for $£ 40,000$, the East India Company being at that time engaged in the first Burmese War. She ras employed carrying despatches between Calcutta and Rangoon, and on the occasion of the Treaty of Malwa, she saved the Govern- 
ment six lacs of rupees by reaching Calcutta in time to prevent the march of troops from the upper provinces.

When the Exterprize arrived at Calcutta from England she was piloted by a young man, a mate in the Bengal Pilot Service, named Thomas Waghorn.

Mr. Waghorn was born at Chatham in 1800, and was, consequently, in his twenty-sixth year when he acted as pilot for the Exterprize. He had served four years in the Royal Navy, and was afterwards for twelve years in the service of the East India Company as pilot, subsequently rejoining the Royal Navy, in which he remained until he obtained his commission as Lieutepant. He was selected in $182 \pi$, by the Indian Government (Calcutta Steam Committee), for the purpose of establishing steam navigation between England and India. He visited London, Liverpool, and Manchester, but could not obtain sufficient financial support for a regular service of steamers via the Cape of Good Hope. Hearing that it was the intention of the East India Company to despatch the Enterprtze to Suez, he offered his services as Courier to the East to Mr. Lock (Chairman of the East India Company), and to Lord Ellenborough (President of the Board of Control). His offer of service was accepted, and he left London on the 28th October, 1829, taking the overland route, via Trieste, to Alexandria, where he arrived on the 27th November. His instructions were to proceed with his despatches for the Governor of Bombay (Sir John Malcolm), by the steampacket Exterprize from Suez, but owing to a breakdown of her machinery, the steampacket was not at Suez to meet him. There being no steamer to take him on to his destination, Mr. Waghorn embarked on an open native boat, and sailed down the Red Sea, being subsequently picked up by the Fast India Company's sloop THETIs, which had been sent to meet him, and which brought him to Bombay. The day previous to the arrival of Mr. Waghorn at Bombay, the Last India Company had despatehed the steamer Hugir Linissay to Suez to take up the sailing of the disabled ExtErprizk. The Hugir Lindsay continued to make one round royage between Bombay and Suez annually until 18:36, during the 
north-east monsoons, not being sufficiently powerful to make the passage during the south-west monsoons. In 1836 the Court of Directors of the Fast India Company decided to place on the station two new and more powerful steamers. These were the Atalanta, of 616 tons burthen and 210 horse power, built in 1835 at a cost of $£ 36,652$; and the Berenice, of 664 tons and 230 horse power, built the same year at a cost of $£ 40,124$.

While a regular steamship service was thus being established between the Isthmus of Suez and Bombay, the British Government had established a service of Admiralty packets between Falmouth and Cadiz, Gibraltar, Malta, and Corfu. From Malta the mails were conveyed to Alexandria by other of H.M. ships. Prior to 1830 the Admiralty packets were all sailing brigs, but on the 5th February of that year the Mетвоr, the first of the steampackets, sailed from Falmouth to the Mediterranean. She was followed by the steampackets African, Carron, Columbia, Confraxce, Echo, Firfirand, Hermes and Messenger.

About 1834 Messrs. Bourne, of Dublin, the principal owners of the Dublin and London Steampacket Company, were induced by the Spanish Minister in London to start a line of steamers between London and the Peninsula. They placed the management of the steamers in the hands of Messrs. Willcox and Anderson, a London firm with whom they had had some previous transactions. Messrs. Willeox and Anderson were well acquainted with the trade to the Peninsula, having been engaged in it, at first with sailing vessels, and afterwards with chartered steamers. The new line was called the Peninsular Steam Navigation Company, and Mr. James Allan, then a clerk in the Dublin Office of the Dublin and London Steampacket Company, was sent to London to assist Messrs. Willeox and Anderson in the management.

The first steamer of the service was probably the Roral. TAR, belonging to the Dublin and London Steampacket Company, which had been chartered in 1834 to Don Pedro, and subsequently to the Queen Regent of Spain, Messrs. Willcox and Anderson being the chartering brokers. The "Graphic" 
Xmas Number for 1901 states the Wм. Fawcert was the first P. \& O. steamer, and the "P. \& O. Pocket Book" (1900 edition) hearls the list of the past and present fleet of the company with the name of the same vessel, built in 1829 . It is only necessary to say here that neither the Peninsular Steam Navigation Company nor the P. \& O. Steam Navigation Company were in existence at that date. The Wr. Fawcert was certainly built that year by Caleb Smith, and engined by Fawcett and Preston, both Liverpool firms. For some time she was engaged as a ferry boat on the Mersey, and in the early thirties she was employed as a regular trader between London and Dublin. She probably was chartered for a short time to the Peninsular Steam Navigation Company in 1835 or 1836 , as she does not appear in the company's advertised sailing list for $18: 38$.

In the latter year the fleet consisted of the following vessels, from London to Vigo, Lisbon, Cadiz and Gibraltar:Tages, 800 tons gross, 300 h.p.; Royal 'Tar, 650 tons gross, 264 h.p.; Braganza, 650 tons gross, 264 h.p.; Iberia, 690 tons gross, 200 h. p.; Liverpool, ${ }^{*} 500$ tons gross, 160 h.p.; City of Londonderry, ${ }^{*} 500$ tons gross, 160 h. p. Branch steamers, Peninsula, Guadalquiver, Estrelia and Sol.

In 1837 the Government advertised for tenders from steamship owners for the conveyance of the mails between Falmouth and the Peninsula, which up to that time were conveyed by sailing brigs which left Falmouth for Lisbon every week, "wind and weather permitting." In response to this advertisement two companies, the British and Foreign Steam Navigation Company, and the Peninsular Steam Navigation Company, sent in tenders. The former company having failed to show that it had adequate means for the efficient performance of the Postal service, the Government concluded a contract, on the 29th August, 183\%, with the Peninsular Steam Navigation Company, by which that company agreed to convey monthly the whole of the Peninsular mails for an annual subsidy of $£ 29,600$, afterwards reduced to $£ 20,500$. The first steamer to be despatched under this contract was the IвerLa, in September, 18:3\%, calling at Vigo,

* Chartered Steamers belonging to the City of Dublin Co. 
Oporto, Lisbon and Cadiz, on its passage to and from Gibraltar.

The British Government in 1839 entered into an arrangement with the French Government to send letters to and from India through France by way of Marseilles. The mails were conveyed between Marseilles and Malta by an Admiralty packet, and between Malta and Alexandria by another Admiralty packet. This arrangement did not work satisfactorily, and the Government advertised for tenders for a line of steamers, to run direct from England to Alexandria and rice versa, touching only at Gibraltar and Malta. The steamers were to be of sufficient power to perform the royage in not more than three days beyond the time then oceupied in the conveyance of the mails via France, and the cost was not to exceed the amount required for the maintenance of the small and inefficient Arlmiralty packets then employed.

Four competitors tendered for the contract, but that of the Peninsular Company was accepted, it being the lowest $(£ 34,200)$, and containing also an offer to convey at a reduced rate all officer's travelling on the public service, and bona fide Admiralty packages gratuitously.

At this time much pressure was brought to bear on the Government to induce it to subsidize a proposed line of steamers between. Falmouth and Calcutta ria the Cape of Good Hope. These steamers, according to the "Times" of the 11th November, 18:38, were to make the passage in thirty days.

The Great Liverpool, of 1,540 tons and 464 horse power, built by Sir John Tobin, of Liverpool, and intenderl for the Liverpool and New York trade; and the ORIExTal, of 1,600 tons and 450 horse power, were the steamers offered by Messrs. Willcox and Anderson, and approved by the Admiralty, to convey mails between England and Alexandria, calling at Gibraltar, and combining the two mail services of the Peninsular and the Oriental, thus constituting the Peninsular and Oriental Steam Navigation ('ompany. Subsequently, the company was requested to provide two steamers, one to be not less than 250 horse power, and the other to be $\mathbf{1 4 0}$ horse vower, for the Malta and Corfu 
branch of the mail service, which was done at a cost to the country of $£ 10, \tilde{i} 12$ per annum, less than the cost of maintaining the Admiralty packets previously employed.

In September, 1842, the P. \& O. Company obtained a contract for carrying the mails between Calcutta and Suez. The contract was granted very reluctantly by the East India Company, and only after much pressure had been brought to bear on it by the Home Government.

On the 24th September, 1842, the P. \& O. Company despatched its first steamer to India via the Cape of Good Hope. She was the paddle-steamer Hindostax, of 2,017 tons gross and of 520 horse power. On her arrival at Calcutta she was placed on the service between Calcutta, Madras, Ceylon and Suez. Other steamers were despatched speedily from England, and in 1844 the company was in a position to enter into another contract with the Government for a monthly service from Ceylon, to Penang, Singapore, and Hong Kong. For the premier service (Suez-Calcutta) the company received $£ 115,000$ per annum, or at the rate of 20 s. per mile, and for the Ceylon-Hongkong service $£ 45,000$, or at the rate of about 12s. per mile.

In connection with the Eastern services, coaling stations, docks, store establishments, and in such places as Suez and Aden, even fresh-water supplies had to be, and were, provided and organised.

At this period, and until the completion of the Railwav from Alexandria to Suez, the passengers and cargo carried bv the P. \& O. steamers were conveyed across Egypt in a somewhat primitive manner. The Mahmoudieh Canal enabled the company to transport its passengers and cargo from Alexandria to the Nile, whence they proceeded by steamer to Cairo, and thence through the desert on the backs of camels, a distance of less than 100 miles, to Suez.

As it was notorious that the mail service between Suez and Bombay was conducted by the East India Company at a cost of upwards of $30 \mathrm{~s}$. per mile by steamers vastly inferior in speed and accommodation to the P. \& O. steamers, which maintained the mail services to India and the principal ports of China at an average rate of about 17s. per mile, the public 
naturally demanded that the Suez-Bombay service should be taken out of the control of the Fast India Company, and placed in the hands of those competent to work it more efficiently and with greater economy. The demands of the public, although confirmed by the Parliamentary ('ommittee of 1851, were successfully resisted by the C'ourt of I)irectors until 1854, and it is questionable if even then, they would have given up the service if (in consequence of the East India Company having no steamer ready for them at Nuez) the Bombay mails had not been lost in a native sailing craft into which they had been transferred at Aden.

The P. \& O. ('ompany were applied to by the Government, and undertook this service for the sum of $£ 24,700$ per annum, or at the rate of $6 \mathrm{~s}$. 2d. per mile, resulting in a decreased expenditure of about $£ 80,000$ per annum, as compared with the expense incurred by the far less efficient East Indian Navy.

In 1852, the P. \& O. Company extended its operations to Australia, by means of a branch line of steamers from singapore. The following year saw an addition of no less than eleven steamships to the company's fleet. Amongst these was the celebrated troopship НImAsisa, which continued in active service until near the end of the century. At the time of her launch she was the largest steamship afloat, and of extraordinary speed. She cost $\mathfrak{\pm 1}: 32,000$ when fully equipped and rearly for sea. Her length was 340 feet, beam $4 t$ feet ( inches; her gross tonnage was :3,4:38 tons, and her engines indicated 2,050 horse power.

Another famous steamer built for the $P$. \& 0 . in 1853 was the CoLonвo (steamship), which was engaged as a Government transport during the Crimean War. Even Santa Claus himself could not have been more eagerly welcomed than was the Соцомво when she arrived off Sebastopol on Christmas Eve, 1854, with provisions for the wounded soldiers and sailors. She was originally a vessel of $1,86+$ tons gross, but in 1859 she was lengthened amidships, and her tonnage increased to 2,127 tons. The Hmasaya and the Colombo were two, out of eleven, P. \& O. steamships chartered to the Government as transports during the Crimean War, and these 
vessels conveyed during the continuation of hostilities 1,800 officers, 60,000 men and 15,000 horses.

The first steamer of the P.\& O. Company fitted with compound engines was the Mooltax (steamship), of 2,257 tons, built in 1860-1. Several succeeding steamers were fitted with the same type of engines, but although the consumption of fuel was decidedly less, the engines themselves proved so unreliable that they were taken out of all the ships and replaced by the old style of engines. "It was not until 1869 " (says Sir Thomas Sutherland, in the "P. \& O. Poeket Book," 1900 ) "that the company succeeded in building a steamer" with high and low pressure machinery which could be considered thoroughly successful."

On the 1ith November, 1869, the Suez Canal, the greatest engineering work of the 19th century, was formally opened by the Empress Eugenie, in the presence of numerous distinguished men from all countries. While the benefits conferred upon the world of commerce by the opening of this canal can hardly be over-estimated, its influence upon the fortunes of the P.\& O. Company was at first almost fatal. The whole of the company's business had to be re-organised, and as speedily as possible a new fleet obtained arkapted to the changerl requirements of the company's services. This transitory state continued for a period of five years, from $18 \pi 0$ to 1875 , by which date the company's re-organization was sufficiently accomplished to enable them to transfer their services from the Overland to the Suez ('anal route. The accelerated mails sent ria Brindisi were still carried by the Egyptian Railway between Alexandria and Suez, and continued to be so carried until 1888, when they also were transferred to the Canal route.

It is interesting to compare the earlier vessels of the company's fleet with the later. The IN1) , built in 1839 , was a ressel of $8 \pi 1$ tons, and with engines of 300 horse power. Her namesake, built in 1896, is a steamer of $\tau, 911$ tons, with engines of 11,000 horse power. The Persta, built in 1900, has a slightly larger register (8,000 tons), with engines of the same power. In 1901 four twin-screw steamers were added to the fleet, the Syria, Soudan, Somali and Sicilia, each of 6,600 
tons gross, with engines of 4,500 horse power, while 190:3-4 witnesses the addition to the C'ompany's list of the Marmora and Macedonia, 10,500 tons and 15,000 horse power, and the Molmavia and Moxgolia, 10,000 tons and 14,000 horse power, as well as several cargo steamers of immense tonnage.

During the war in the Transvaal, as at the time of the Crimean War, many of the steamers of the P. \& (). Company were engaged by the Government as transports.

The following figures indicate the extensive operations of the company:-In 1899 the mileage traversed by the steamers of the fleet during the year was about $3,000,000$ miles. 'The consumption of coal during that period was 625,000 tons. The dues paid to the Suez Canal Company exceeded $£ 272,000$, while the sum expented in wages to officers and crews amounted to $£ 362,000$.

In 1855 the Directors of the East India Company advertised for steamers to earry the mails between Calcutta and Burmah, a service inaugurated by the ExTERPrize (see ante) in 1826, and afterwards conducted by various vessels of the liast Indian Navy. Messis. MeKinnon \& Co., of Glasgow, tendered in response to this advertisement, and their tender having been accepted, they despatched the two steamers BALtic and CAPE of Goon Hope to fulfil their contract. These vessels were small and unsuitable for the intended service, and the result would have been a sericus financial loss to their owners, had they not, soon after their arrival in India, been engaged for transports on the outbreak of the Indian Mutiny.

'The new company traded under the title of the Calcutta and Burmah Steam Navigation Co., its first operations being confined to the ports of Calcutta, Akyab, Rangoon and Moulmein. One of the two pioneer steamers, the CAPE of Goon Hope, collided with a $\mathrm{P}$. and $\mathrm{O}$. steamer and sunk in the Hooghly. Another, the Calcutra, of 900 tons, was totally lost off the coast of Wicklow, when on her first voyage from the Clyde to Calcutta. A fresh contract was entered into in 1862 with the Indian Government, and in the same year the title of the Company was changed to the British India Steam Navigation Co., Limited. The terms of the new contract included the transport of troops and stores at a mileage rate; a mail service 
every fortnight between Calcutta, Akyab, Rangoon and Moulmein; also a monthly service via the two latter ports to Singapore; a similar service to Chittagong, and one to the Andaman Islands; as well as one between Madras and Rangoon; a fortnightly service between Bombay and Karachi; and a service, once every six weeks, to various ports in the Persian Gulf. New vessels were built and despatched for these various services, and the traffic of the Company developed with great rapidity.

The career of the Company was, however, not an unchequered one. In addition to the two steamers referred to as lost during the first year of the Company's existence, must be added the wreck of the Burmail on the Madras coast, the loss of the Bussorah on her voyage to India, and the foundering of the Persia on her voyage from Rangoon to Calcutta, during one of those fearful cyclones which periodically sweep the Indian Ocean.

The opening of the Suez Canal in 1869, which for a time adversely affected the fortunes of the $\mathrm{P}$. and $\mathrm{O}$. Co., proved beneficial to the British India Steam Navigation Co. The directors of the latter Company at once took advantage of the facilities which it offered, and their steamer IxDia, requiring new boilers, was despatched to England, and was the first steamer to arrive in London with a cargo of Indian produce via the Suez Canal. Since that date the Company has added steamer to steamer until at the present date (1903) its fleet (inclusive of the British India Association steamers) numbers upwards of 120 vessels.

In July, 1891, Messrs. Bibby Brothers, of Liverpool (a firm which was founded in 180\%), established a direct service of first-class and swift steamers between the United Kingdom and Burmese ports. For half a century prior to 1901 Messrs. Bibby had maintained steamship communication between Liverpool and all the principal ports of the Mediterranean. Prior to the construction of the Suez Canal, cargo from the East was carried by the P. and $\mathrm{O}$. to Suez, thence by rail to Alexandria, where it was transhipped to the Bibby steamers, which loaded in Alexandria for Liverpool.*

* A sketch of the history of this important Firm will be found in Part II. of this Volume. 


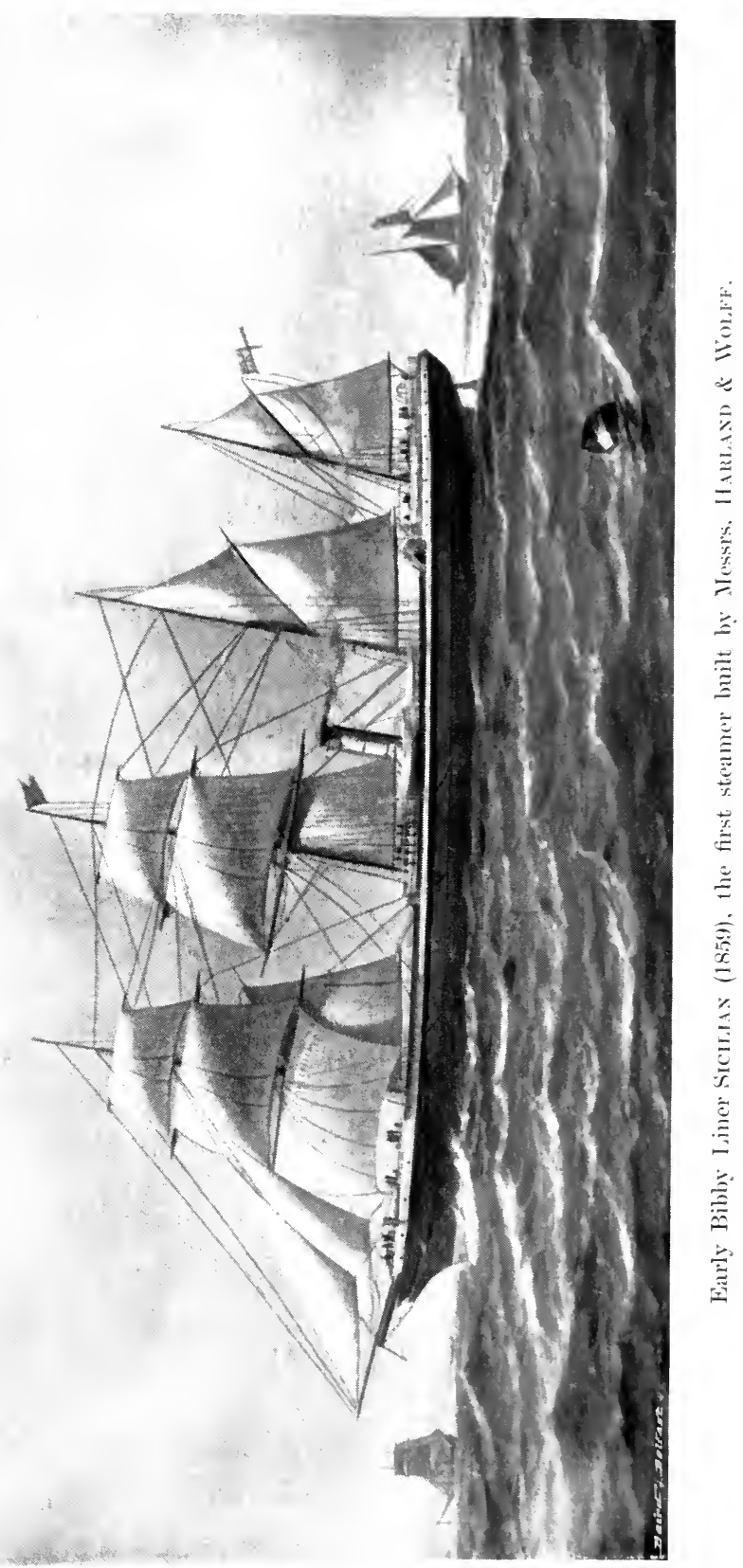




\section{Chapter $\mathrm{X}$.}

Steamers on the Pacific.-The Telica (1825).-P. S. N. Co., 1840.-Compound Engines adopted, 1856.- Service extended from West Coast, South America, to the River Plate (1865), and to Liverpool, 1868.-The P. S. N. Co. and Messis. Anderson Anderson \& Co., 1878.-Gulf Line of Steamers between Great Britain and West Coast, South America.

T'He first steamer to trade along the Pacific Coast of South America was a small steamer, named the Truics, in 1825. She was owned and commanded by a Spaniard bearing a Russian name, Mitrovitch. The venture proved a failure, chiefly owing to the seareity of fuel, and the unfortunate man, in a fit of despair, fired his pistol into a barrel of gunpowder, and blew up his vessel in the harbour of Guayaquil, destroying himself and all on board, except one man.

The next person to attempt to establish steamship communication along the Pacific Coast was an American citizen, Mr. William Wheelwright, born in Newburyport, Mass., U.S.A., in 1698, and appointed United States Consul at Guayaquil in 18:4. Mr. Wheelwright, notwithstanding the tragie fate of the T'ELICA and her owner, was eonvinced of the importance of steam communication to the development of the rich resources of the western side of the South American Continent, spent six years in arranging plans for steam eommunication between the different Republies, and at last obtained from the Peruvian, Bolivian, and Chilian Governments the privilege of establishing and maintaining a steamship service along their respective eoasts for a period of ten years. In pursuance of this object he came to England, and secured the co-operation of several wealthy merchants, and on the 1ith February, 1840, a charter was obtained for the establishment of the undertaking known as the Pacific Steam 
Navigation C'ompany, together with a small subsidy for the conveyance of the mails. It was not the intention of the founders of the company to trade elsewhere than along the Pacific Coast, and for this purpose a capital of a quarter of a million pounds was thought to be sufficient. The eapital consisted of 5,000 shares, $£ 50$ each. Only the amount required to build two small steamers was called up. These steamers were the ChILI and PERU, each of about $r 00$ toms gross legister, with engines of about 150 horse-power nominal. They were brig-

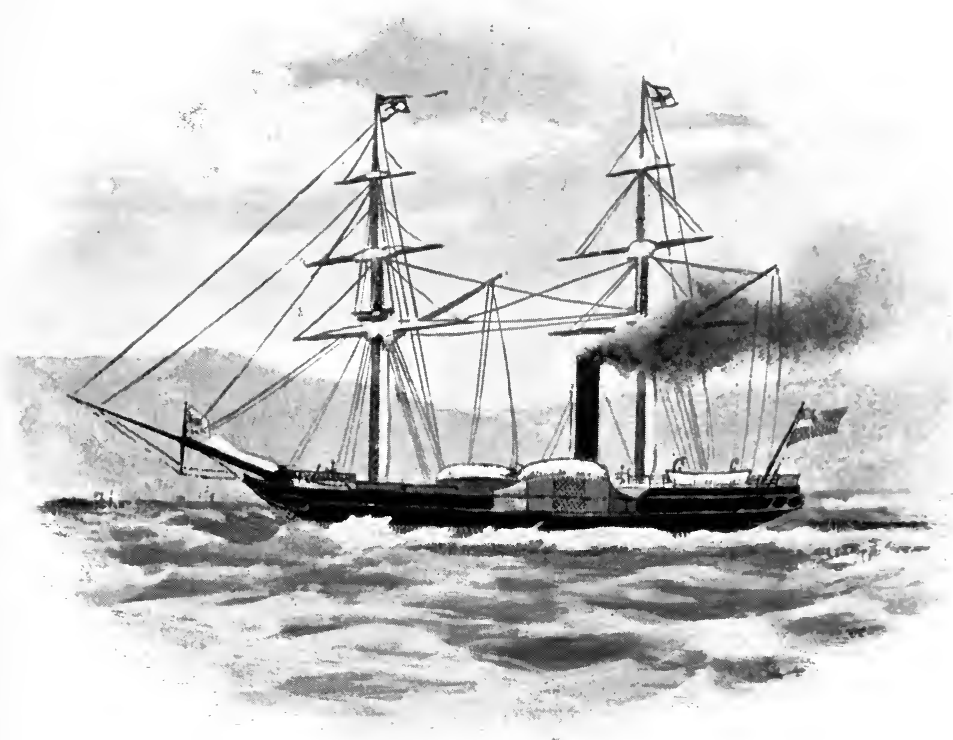

Peru. Pacific Steam Navigation Co., Ltd.

rigged paddle steamers, built of wood, by Charles loung and Co., Limehouse, London, and engined by Miller \& Ravenhall.

Owing in great measure to the seareity of fuel on the coast, the company, during the first five years of its existence, sustained a loss of four-fifths of its paid-up eapital, but the shareholders courageously resolved to persevere with their undertaking. The seat of management of the company was, however, transferred from Loudon to Liverpool (1846), and the 
late Mr. William Just appointed Managing Director. The following year (1847), the Directors were for the first time able to declare a dividend, a modest two-and-a-half per cent.

In 1850, having obtained an extension of the Government Postal contract, the Jirectors ordered four steamers, at a total cost of $£ 140,000$. These steamers were named the Lima, Saxtiago, Quito and Bogota, and were each of about 1,000 tons gross and 300 horse-power nominal.

In 1856 the company's service was re-organised by Mr. Just, who visited the West Coast specially for that purpose. During the same year the compound type of engines was adopted in the company's steamers, the Pacific Steam Navigation Company being thus one of the earliest ocean steamship companies to use this type of engine.

A supplemental charter was obtained in 1865, extending the operations of the company, and authorising steamship communication between the West Coast of South America, and the River Plate on the East Coast.

As the profits of the company had been steadily increasing for a number of years prior to 186i, it was resolved at a meeting of shareholders, held in December of that year, to establish a monthly line of steamers from Liverpool to the West Coast of South America, via the Straits of Magellan, and to increase the capital of the company to $£ 2,000,000$.

The first new steamer of the new service was the Pacific, 1,630 tons gross register, 1,174 tons net, with engines of 450 horse-power. Her principal dimensions were, length $26 \tau$ feet, beam 40 feet, depth 17 feet. She was built on the Clyde in 1864, by Randolph Elder \& Co., and cost $₫ 61,855$. After trading for about three years on the Pacific Coast, she sailed from Valparaiso for Liverpool in May, 1868, as the pioneer steamer of the new mail service. I) steamers of about 3,000 tons each, specially built for the maintenance of this service, were added to the company's fleet. These were the John Eldor, Magellan, Patagonia, Araucania and Cordillera.

So profitable was the Liverpool trade to the West Coast, the Directors determined in 1870 to make the sailings fortnightly, 
and in that year they alded the stramers Chrmborazo, ('Uzco, Garonne, Lusitania and Aconcagea to the fleet.

In December, 1871 they recommended a further increase of the company's capital to $\mathfrak{E}:, 000,000$, with a view of making the service from Liverpool a weekly one. 1)uring the year they had greatly increased the number of the company's ocean steamers, having built in $18 \pi 1$ seven steamers, each of about 4,000 tons gross, vi\%, the Sorata, Illimasi, Cotopaxi, Galicha, Corcovado, Prno and Potosi.

In July, 1872, the capital of the company was raised to $£ 4,000,000$, and the steamers Valparaiso and Britannia were added to its fleet, and in the following year the Imskis and LigURIA.

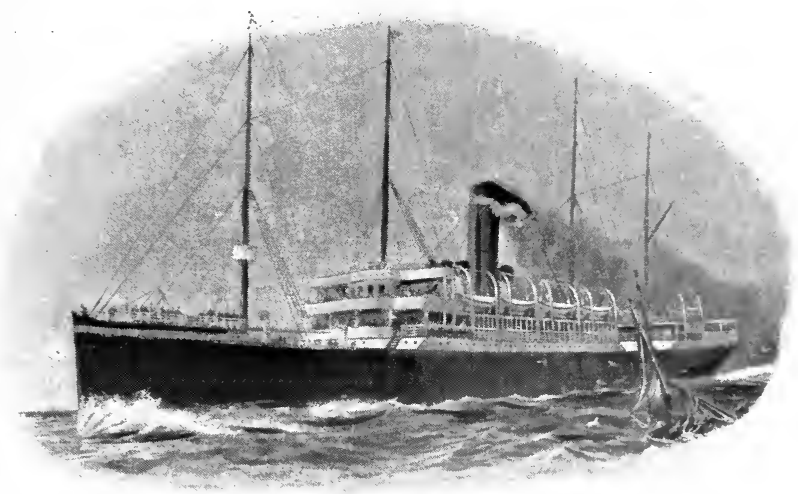

Orellaxa. Pacific Steam Navigation Co., Ltd.

In addition to the above steamers, which were all built for the Liverpool to West Coast service, the Pacific Steam Navigation Company built during the years 1869 to $187:$ ) inclusive, eighteen steamers for its Pacific Coast service.

The IBERIA and Liguria were the last of the barque-rigged, clipper-bow type of steamer built for the Pacific steam Navigation Company. The suceeeding ressels of the fleet have as a rule four pole masts and a straight stem.

Although the trade between Liverpool and the West Coast of South America had increased with marrellous rapidity, the 
increase in the company's tonnage had more than kept pace with it. It was found that the combined passenger and cargo trade would not support a sailing each week, and the sailings were reduced to two each month. As a consequence of the reduced number of sailings, as many as nine of the company's steamers were at one time laid up for want of employment. In $18 \% 8$ the Directors were fortunately able to charter four of their vessels, the Cimmorazo, Lusitania, Cuzco and Garonne, to Messrs. Anderson, Anderson \& Co., who in that year founded the Orient Line of steamers from London to Australia. In 1882, when the latter company decided to double its sailings, the Pacific Steam Navigation Company made arrangements to employ several additional steamers in the Australian service. Although the Pacific Company was the first to establish steamship communication between Great Britain and the West Coast of South Imeriea, it has har to share the traffic in later years with the Gulf Line of steamers belonging to the Greenock Shipping Company, and with the steamers belonging to Messrs. Lamport \& Holt.

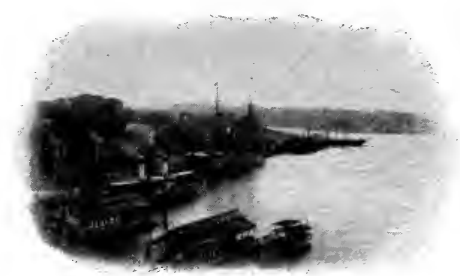




\section{Chapter XI.}

French-Algerian Expedition, 1830.-Civil War in Portugal.-Loss of the steamer Rival.-Nutiny on a Transport.-Loss of the Lord BLANFY.-The Margaret, first serew passenger steamer trading from Hull.

Faru in the year 1830, the Fromch Government fitted out an expedition against the Dey of Algiers, and an agent of the former was instructed to contract with the City of Dublin and the St. George Steam-Packet Companies for the employment of some of their first-class boats as transports in the expedition. The vessels chartered were ordered to proceed immediately to Toulon to embark French troops for service in North Africa. This was the first instance of steam vessels being extensively engaged in warlike expeditions. At this date, Portugal was engaged in a prolonged and sanguinary civil war, in the course of which vessels belonging to both of the famous Liverpool steamship companies were again employed.

Don Miguel (surnamed the Usurper) had about the year 1826 assumed the government of Portugal. It is calculated that in the short space of five years he imprisoned $26,2 \% 0$ of his beloved subjects; 16,000 were transported to various places; 13,000 were forced to fly from his paternal government; $1: 3, \tilde{7}(00$ perished on the scaffold; and 5,000 were either in concealment or wandering about the kingdom to aroid a similar fate. Finally, Dom Pedro, limperor of Brazil, on behalf of his daughter I)onna Maria of Portugal, took active measures to recover the throne. A number of British steamers were engaged as transports or privateers in the civil war that ensued. Amongst other vessels was the "ill-fated steamer" "* RivaL,

$\because$ There is some doubt as to whether this vessel was a steamer or a sailing brig. The "Liverpool Mercury" speaks of lier as the "ill-fated steamer, Rival" ; but the "Glasgow Herald " only refers to her as the " brig Rival." 
which sailed from Greenock on the 22nd December, 1832, bound for Oporto, with about 400 volunteers for Dom Pedro, and foundered in Galway Bay, with the loss of nearly 500 lives. Some spars, bedding, and ship's papers were washed ashore, but as not one of the passengers or crew escaped, no particulars can ever be known of the circumstances attending the fatal disaster.

The Lord Blaney was one of several of the St. George Steam-Packet Company's vessels chartered for the same service. It appears from a record of magisterial proceedings (August, 1831) before Mr. H. Leach, of Milford, that the agents employed by Dom Pedro hired 200 seamen at Liverpool, and induced them to ship on board the LoRn Blaner, under a pretext that they were merely wanted to navigate British transports across the Atlantic, to convey some regiments of Portuguese from Rio de Janeiro to Europe; but no sooner had the Lord BLANEY got fairly into the Irish Channel than the officers threw off the mask, and acknowledged their destination to be Belle Isle, for the purpose of manning Dom Pedro's fleet. Finding themselves thus entrapped, the seamen exhibited signs of mutiny, and a violent gale of wind having forced the steamer into Milford Haven for shelter, the whole body of tars went ashore with bed and baggage, declaring their intention not to fight under any flag but that of England. After completing her engagement with Dom Pedro, the Lord Blaney was placed on the Liverpool and Newry service, and on the 18th December, 1833 , she was lost with all hands (45) whilst on a voyage from Newry to Liverpool. A subscription list was opened for the benefit of the families and relatives of the crew and passengers. The City of 1)ublin Steam-Packet Co., although in active opposition to the St. George Steam-Packet Co., headed the list with the handsome donation of $£ 100$. Two, at least, of the City of 1)ublin Steam-Packet Co.'s vessels took part in the Portuguese war, the Lisens and the Birmixginam. The latter steamer, under the command of Captain Beazley, arrived at Falmouth about the 15th July, 1833. She brought despatches from Lagos which contained intelligence of the most important and decisive nature, nothing less than the complete defeat and capture of 
the fleet of the Usurper. The news was received with the utmost satisfaction in Eingland as well as Portugal.

The Margaret steamship sailed from Hamburg to Hull on Friday, 19th October, 1845, with a number of passengers and a full general cargo. Shortly after leaving the Elbe she encountered a north-west gale, and after beating against it for two days, she was driven on to a dangerous bank called the Memmett, near Juist, at the entrance to the river Memm. The moment she took the shoal, the sea, which was running very high, swept several overboard. The long boat was launched and an attempt made to reach the shore, but owing to it being crowded it capsized, and every soul in it perished. From advices received, it appears that altogether sixteen of the passengers and three of the crew were lost. Those who remained on board the vessel, after severe privations, were rescued. The Margaret was owned by Mr. Pimm, of Hull; was several years old; was about 250 tons burthen, and was rigged as a three-masted schooner. She was worked by a screw propeller, and was the first vessel of that description engaged in the passenger trade from the port of Hull.

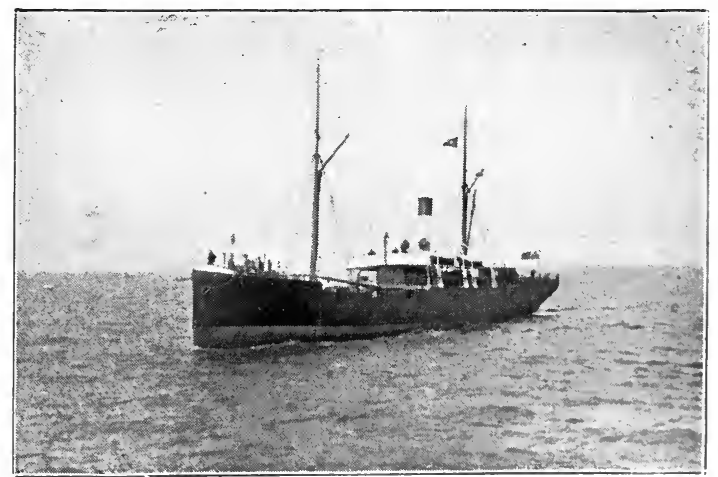


THE HISTORY OF STEAM NAVIGATION, [PART I.

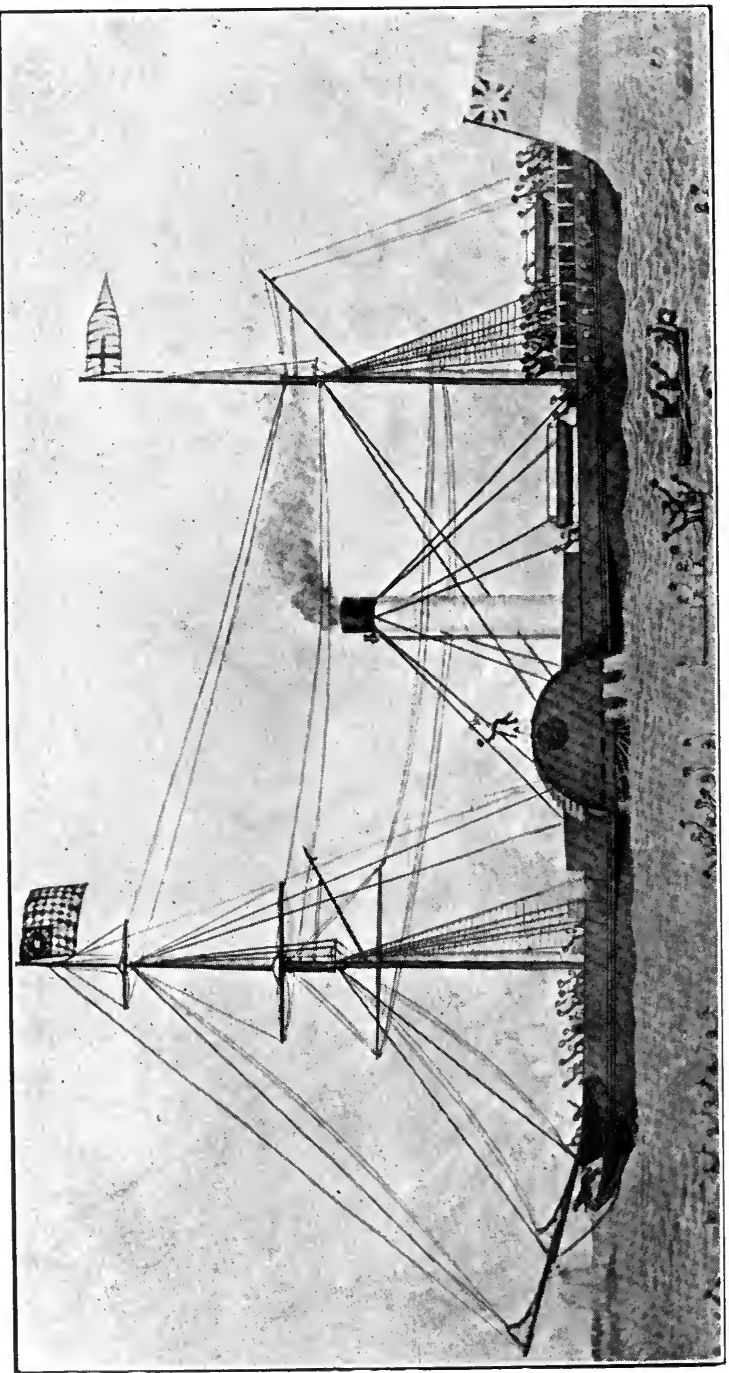

要 


\section{Cifapter XiI.}

Pioneers of Transatlantic steam navigation.-Valentia Transatlantic S. N. Co. incorporated, 1828.-Dr. Lardner's famous speech on Steam Navigation.The Royal Willian, first steamer from Canada to England, 1833; sold to Spanish Government and re-named Ysabel Segunda.-The British Queen S. N. Co.-Launch of the British Queen, 1838.-Sirius, first passenger steamer from Europe to America, 1838.-Great Western, 1838.-Arrival of both steamers at New York on same day.-The Royal William, first Atlantic liner from Liverpool to New York, 1838. - The Liverpool.-The President launched, 1839; lost, 1841.

A QUARTER of a century had elapsed since the launch of Bell's Comet on the Clyde. In the interval, all the chief ports of Great Britain and Ireland, and several of the continental ports, had been connected by steampacket services. So early as 1828 it had been proposed to establish steam communication between the West of Ireland and America, and an Act of Parliament for incorporating the Valentia Transatlantic Steam Navigation Company was obtained. The proposed capital was $£ 24,000$, in shares of $£ 50$ each. The first steamer was estimated to cost $£ 21,000$. She was to be a vessel of about 800 tons burthen, driven by engines of 200 h.p., and was expected to make six round voyages per annum. She was to accommodate 50 cabin and 50 steerage passengers, and to carry 200 tons cargo, exclusive of bunkers. It appears from the following extract from the "Liverpool Albion" of the 14th December, 1835, that although the projectors of the Valentia Company advertised in 1828 that the company was "to commence immediate operations," its first sailing had not taken place seven years later. The scheme fell through for want of support, but in 1835 it was started afresh in conjunction with the railway from London, the Post Office Packets, and the Valentia Railway. The extract 
is valuable also as containing Dr. Lardner's famous dictum concerning the possibility of direct steam navigation between Liverpool and New York:-

"Steam Communication with America.

"Dr. Lardner then proceeded to observe that one of the "grandest projects which had ever occupied the human " mind was at present in the process of actual accomplish"ment. He meant that of constructing a great highway "for steam intercourse between New York and.London"between the capital of the New World and that of the "Old. Part of the highway was in process of formation. "It consisted of several stages-that of the railroad from

"London to Birmingham; that from Birmingham to "Liverpool, and the steam intercourse with Dublin; but " there was another stage-that from Dublin to Valentia, "which had as yet hardly been thought of. Ireland was " a country which, with all her political disadvantages, was " blest by nature with a vast number of physical advan"tages, and amongst the rest he might reckon a vast " number of excellent harbours. No country in the world " could boast of so many fine and spacious ports, bays and "roadsteads. She had many harbours on her west coast "which would serve admirably as stations for steam con"veyance across the Atlantic; but Valentia had been "selected as the extreme westerly point suitable for that "purpose. It was a fine anchoring ground by an island " of that name on the coast of Munster. The distance "from Dublin to this point was under 200 miles, which " might be traversed in about 8 hours. The nearest point " on the continent of North America to this point of "Ireland was St. John's in Newfoundland. The distance "between the two was about 1,900 miles; thence to "Halifax, in Nova Scotia, there would be another run of " 550 miles, and from that to New York would not exceed " the admissible range; but touching at Halifax would be "desirable for the sake of passengers. The only difficulty "would be as to the run from Valentia to St. John's; and " the voyage from Dublin to Bordeaux and back, a distance 
" of between 1,600 and 1,700 miles, with the same stock of " coals, came very near this distance. It must be observed " that westerly gales blew almost all the year round across "the Atlantic. They were produced by the trade winds " being the compensating cause that restored the balance " which these served to destroy, according to that beautiful "principle in nature which always provides a remedy for " any derangement in the deranging cause itself. As a "last resource, however, should the distance between "Valentia and St. John's prove too great, they might make " the Azores a stage between, so that there remained no " doubt of the practicability of establishing a steam inter" course with the United States. As to the project, how" ever, which was announced in the newspapers, of making " the voyage directly from New York to Liverpool, it was, " he had no hesitation in saying, perfectly chimerical, and " they might as well talk of making a voyage from New "York or Liverpool to the moon. The vessels which "would ultimately be found the best adapted for the "voyage between this country and the United States " would be those of 800 tons, which would carry machines " of 200 horse-power, and would be able to stow 400 tons " of coal. To supply a 10 horse-power daily required an " expenditure of a ton of coals, and, consequently, 200 " horse-power would require 20 tons of coal daily; but if " the vessel carried 400 tons of coal only, it would not be " practicable to undertake a voyage which would require " the whole of the quantity. They must make an allow" ance of 100 tons for contingencies. Thus, in reckoning " the average length of the voyage which might be under" taken by such a vessel, we might safely calculate upon " 300 tons of coal, which would be sufficient for 15 days, " and it might fairly be concluded that any project which "calculated upon making longer voyages than 15 days " without taking in a fresh supply of coals, in the present "state of the steamboat, must be considered chimerical. "Now, the average rate of speed of the Mediterranean "packets was 170 miles per day, and the utmost limit of a 
"steam voyage might be taken at 2,550 miles; but even

" that could not be reckoned upon."

In justice to the memory of Dr. Lardner, it is only fair to state that, in the eighth edition of his "Steam Engine, \&c.," 1851, pp. 294-309, he denies that he ever stated that "a steam voyage across the Atlantic was a physical impossibility."

During the winter of 1832-3, the Quebec and Halifax Steam Navigation Co. built at Quebec a steamer, which they named the Royal William. She was a vessel of $1,3 \gamma_{0}$ tons B.M.; length over all, 176 feet; breadth, outside paddle-boxes, 43 feet 10 inches; inside, 27 feet; depth of hold, 17 feet 9 inches; draught laden, 13 feet. Her engines of 180 h.p., constructed in Birmingham by Boulton \& Watt, were forwarded to Canada, and fitted on board the Roral William at Montreal, whither she had been towed by the steamboat Britisin America. After trading for several months between Quebec and Pictou, Nova Scotia, the station for which her owners had built her, she was advertised to sail for London. In accordance with this announcement she was despatched from Quebec on the 5th August, 1833, and after calling at Pictou, N.S., where she took on board a further supply of coal at 15s. per chaldron, she proceeded direct to Cowes, Isle of Wight, accomplishing the voyage of about 2,500 miles in seventeen days. This voyage is remarkable as being the first instance of a vessel crossing the Atlantic from America by the use of steam only.

After the completion of her trans-Atlantic voyage, the Royal William was sold to the Spanish Government, who changed her name to the Ysabel Secunda, and fitted her up as a manof-war carrying six guns. She took part in the first Carlist war and, finally, was totally wrecked on the rocks off the harbour of Santander, Spain.

After strenuous and prolonged efforts, Dr. Julius Smith succeeded in organising (1836) a Transatlantic Steamship Company, bearing the title of the British Queen Steam Navigation Co. The capital of the Company was fixed at $£ 1,000,000$ sterling, and its secretary was the celebrated Mr. MacGregor Laird. The shares were promptly subscribed for, and the Directors placed a contract with Messrs. Curling and 
Young, Blackwall, London, to build their pioneer steamship, the BRITIsh QueEs. The order for the engines was placed with a Glasgow firm, Messrs. Claude Girdwood \& Co. This firm, however, before they had finished the work entrusted to them, became bankrupt, and a new contract was made with Mr. Robert Napier, the famous Clyde engineer, to supply the engines. It was at first the intention of the Directors (as stated in their prospectus) to build a vessel of 1,862 tons burthen, but before the completion of the ship they decided to increase her size to 2,400 tons. Although contracted for in the summer of 1836, it was not until 24th May, 1838, that the British Queen was launched. This unfortunate delay, caused by the bankruptcy of Messrs. Girdwood \& Co., enabled a rival company at Bristol to build and equip their steamer, the Great Western, before the Britisin Queen could be got ready for her service. In order to save the prestige of their Company the Directors of the Britisir Queen chartered from the St. George Steam-Packet Co. the steamer Sirius, and advertised that she "would leave London for New York on Wednesday, the 28th of March, 1838, calling at Cork Harbour; and would start from thence on the 2nd April, returning from New York on the 1st of May." "The sailing from Cork Harbour was, however, delayed, waiting the arrival of the steampacket OcEAx from Liverpool with the mails and passengers, until the morning of the 4th of April. She started on this memorable voyage at 9 o'clock on the morning of the date named, having on board 94 cabin passengers. Three days later ( $\tilde{\tau}$ th April, 1838) $\dagger$ she was followed across the Atlantic by the Great Western, from Bristol for New York, with goods and passengers. As the dates of the intended sailings of both steamers had been conveyed to New York, their arrival at that port was eagerly looked for. They both arrived on the same day, the Sirius early in the morning of Monday, the 23rd April, and

*The "Annals of Liverpool " section in "Gore's Directory" erroneously states: "1838. The steamship Sirius sailed from London to Cork, 27th March, and from Cork to New York, 2nd April."

† This date is incorrectly quoted in "Gore's Liverpool Directory" as the 8th April. 
the Great Wrstern in the afternoon. The excitement which prevailed on the arrival of these steamers was described as follows by the New York Press:-

"At 3 o'clock p.m. on Sunday, the 22nd of April, the

"Sirius first descried the land, and early on Monday

" morning, the 23rd, anchored in the North River immedi-

" ately off the Battery. Nothing could exceed the excite-

" ment. The river was covered during the whole day with

"row-boats, skiffs, and yawls, carrying the wondering

" people out to get a close view of this extraordinary vessel.

"While people were yet wondering how the Sinius so

" successfully made out to cross the rude Atlantic, it was

" announced about 11 a.m. on Monday, from the telegraph,

" that a huge steamship was in the offing. "The GrEat

“Western ! - the Great Western!' was on everybody's

“tongue. About 2 o'clock p.m. the first curl of her

" ascending smoke fell on the eyes of the thousands of

" anxious spectators, and a shout of enthusiasm rose on

" the air . . . . . Thus the grand experiment has

" been fairly and fully tested, and has been completely

" successful. The only question now in the case is that of

" expense. Can steampackets be made to pay?"

l)uring the early part of her voyage westwards, the Sirius experienced strong head winds, during which she only steamed 4 to 5 knots per hour. During the latter portion, the weather was favourable, and she made good progress, averaging $9 \frac{1}{2}$ knots. She sailed from New York as advertised on the 1st of May, and reached England on the 18th idem after a voyage of sixteen days. The Great Westers left New York on the 7 th of May and arrived at Bristol on the 22nd, being fourteen days on the passage. There was a remarkable difference in her consumption of coal on the two voyages, accounted for, probably, first by the stormy weather referred to as experienced by the Sirius on her outward voyage, and secondly by the prevailing westerly winds on the homeward run. On the voyage Bristol to New York, the Great Wrstern averaged per day 203 knots, or 8.2 knots per hour, with a total consumption of 655 tons of coal. On her homeward voyage she averaged 213 lnots per 
$-\frac{17}{7}$ 


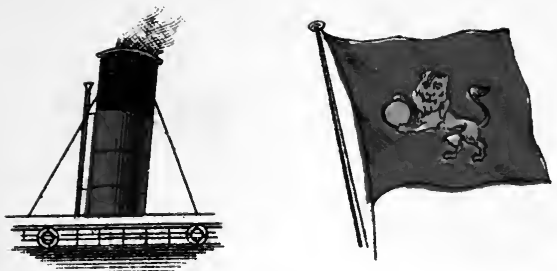

Cunard Line.
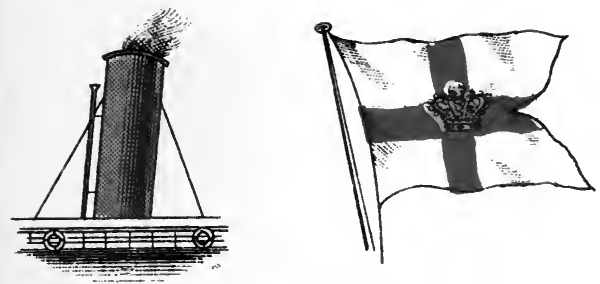

Elder, Dfmpster \& Co.
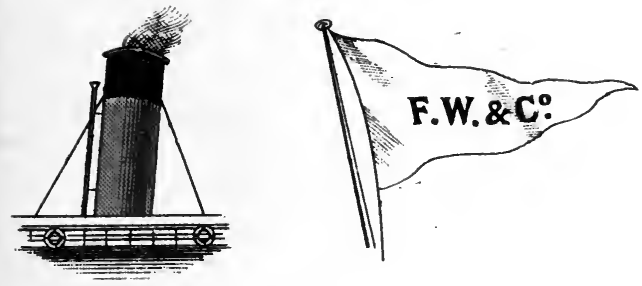

Fletcher, Woodhilt \& Co.
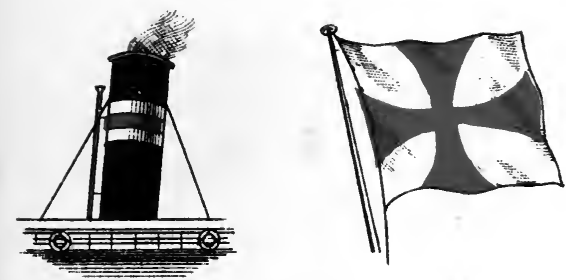

T. \& J. HaRrison.
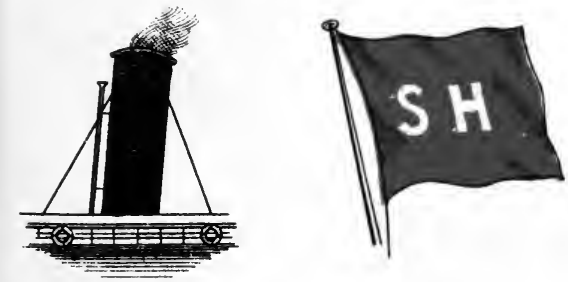

Samuel Hough.
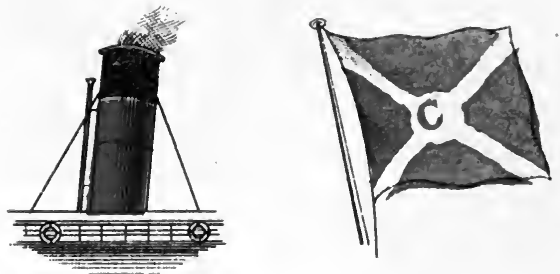

Donald Currie \& Co.
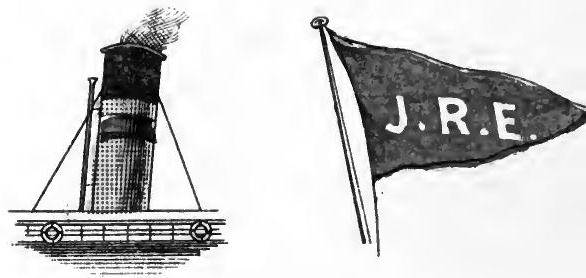

J. R. Ellerman.
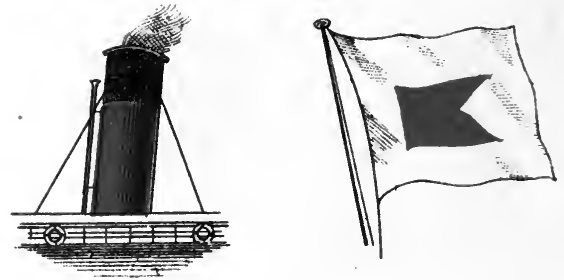

Greenock Shippino Co.
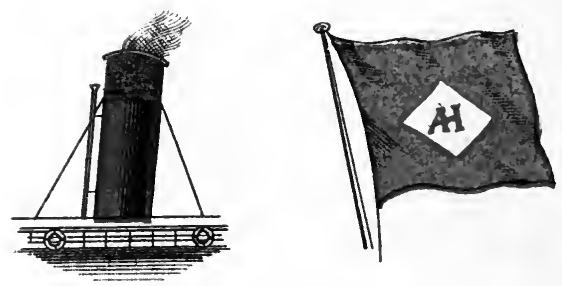

Alfrev Holt.
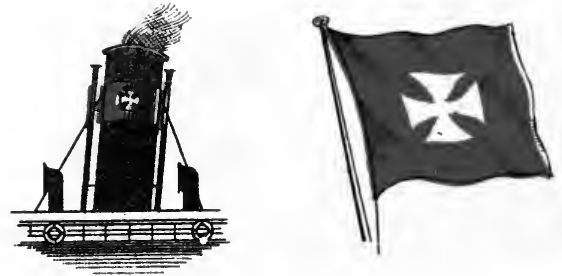

Houlder Bros. 

day, or nearly 9 knots per hour, with a total consumption of only 392 tons of coal. Fuller details of the Sirius will be found in the History of the Cork Steamship Co. in Part II. of this work. It is but fair to state that she was only half the size, and had only half the power of her famous rival. The principal dimensions of the two vessels were as follows:-

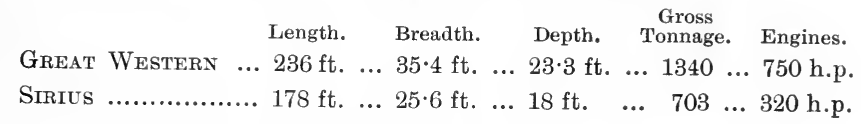

They were both paddle-steamers, built of wood, the former designed by Brunel, and engined by Maudsley, Sons \& Field, and the latter built by Menzies, of Leith, and engined by Wingate \& Co., of Glasgow. For upwards of eight years the Great Western continued to sail regularly between Bristol and New York, on which station she was very popular with passengers. She was sold in $184 \pi$ to the Royal Mail Steampacket Co., in which service she was also a favourite for several years. In 1857 it was the opinion of the I)irectors that she could not compete profitably with modern boats, and she was therefore broken up at Vauxhall.

About the date of the despatch of the Sirius from Cork, the Directors of the City of Dublin Steam Packet Co. had under consideration the formation of a Transatlantic Steam-Packet Co., with sailings to and from Liverpool. The steamers of this Company were amongst the largest and most famous afloat. A meeting of Directors was held in the Committee Room, Water Street, Liverpool, at which it was decided to open up the new service by the despatch of the P.S. Royal William as soon as she could be got ready for the voyage. The Royal William was practically a new steamer, having been built in 1836, being one of four steamers built to compete with the Admiralty steamers for the mail service between Liverpool and Kingstown. She proved herself to be faster than any of the Government mail steamers, and when placed on the Dublin and London station, made a passage from Falmouth to Kingstown, 260 miles, in 23 hours. She was built by Wilson, of Liverpool, and engined by Fawcett \& Preston, of the same city. Her length was 175 feet (being 3 feet less than the Sirius), beam 


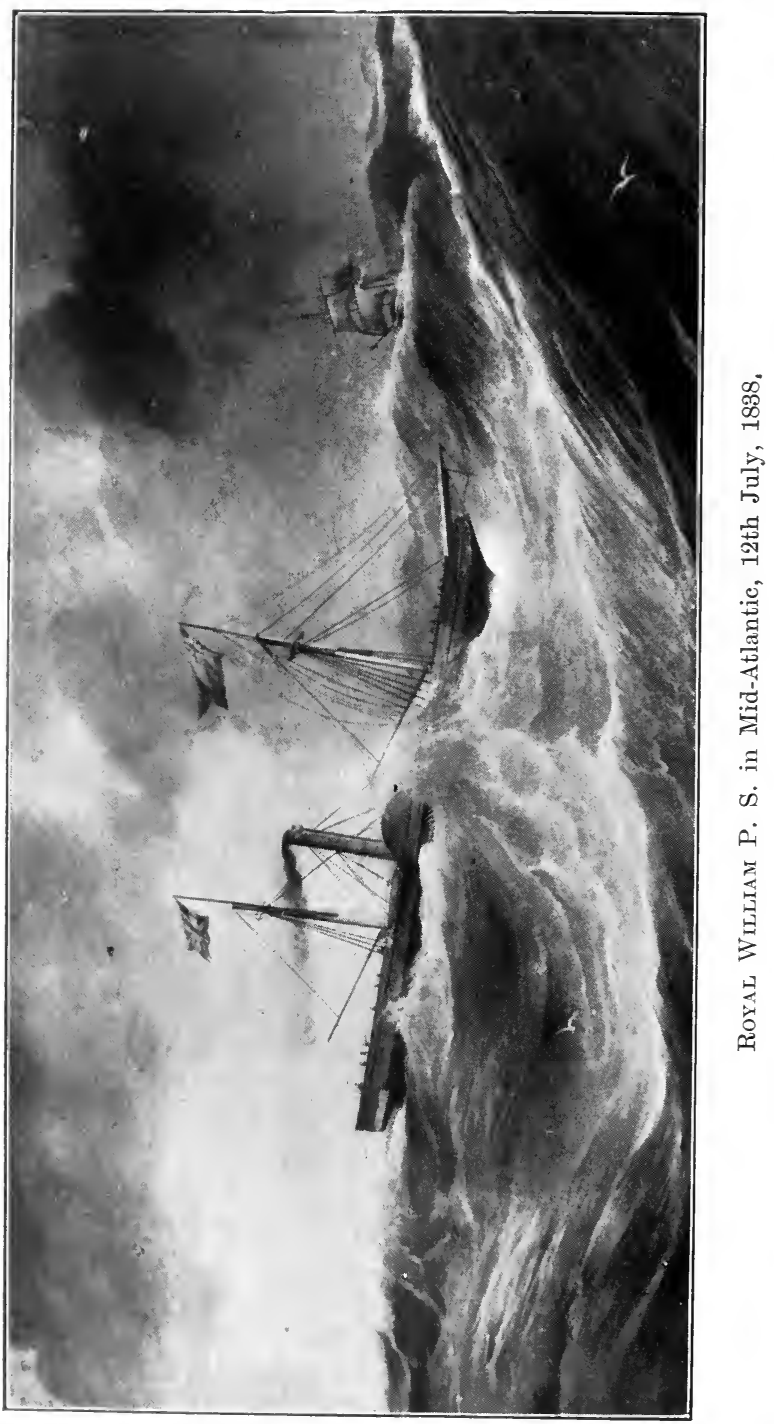


27 feet, depth of hold 17 feet 6 inches. Her capacity was 817 tons burden, and she was propelled by engines of $2 \tau 6 \mathrm{~h}$.p. Her coal consumption was about 17 tons per 24 hours, and in fairly smooth water her speed was $11 \frac{1}{2}$ knots per hour. She had cabin accommodation for eighty passengers. She sailed from the Prince's Pier on Thursday evening, 5th July, 1838, having on board thirty-two passengers. Sixty-four years afterwards the present author had several interviews with Mr. Brownrigg, the City of Dublin Co.'s Customs Clerk, who took out the Customs clearance for the Royal William, and who in spite of his great age remembered clearly the appearance of the vessel as she steamed down the River Mersey on that midsummer evening so long ago. Although she carried no cargo on that voyage, she was so deeply laden with coal for fuelcoal that filled her bunkers, her holds, and even her well-deck - that her paddles were buried six feet, her sponsons were submerged, and it was possible by leaning over the bulwarks to wash one's hands in the water that surged at the vessel's sides. Naturally it was an event in which the townspeople of Liverpool and the residents on the Cheshire side of the river took the deepest interest. As she began to move she was greeted with enthusiastic cheers from thousands of spectators who crowded the piers and lined the river side, whilst cannon were fired from Woodside, Monks Ferry, Rock Ferry, and from the steamboats on the river. The Royal William completed the passage from Liverpool to New York in nineteen days, and the homeward passage in fourteen and a half days.

Amongst those who were present at the meeting held in the Water Street Committee Room was Sir John Tobin, who had a large steamer nearing completion on the stocks. It was agreed that this ressel should sail alternately with the Royal Wildiam between Liverpool and New York. At her launch, Sir John Tobin's steamer was named the Lrverpool. She was a vessel of 1,150 tons, with engines of 404 h.p. She started on her first voyage on the 20th October, 1838, but experienced such bad weather that she put back to Cork on the 26th, after having accomplished about one-third of her voyage. She remained at Cork for ten days, and again proceeded to sea on the 6th 
November, arriving at New York on the 23rd, after a passage of sixteen and a half days. It was on board this steamer that Mr. Samuel Cunard crossed the Atlantic, for the purpose of inducing British capitalists to take up his scheme of mail steamers between Liverpool, Halifax and Boston.

After making a few voyages to and from Liverpool and $\mathrm{New}$ York, the Liverpool was lengthened, her capacity being increased by 393 tons, and at the same time her name was changed to the Great Liverpool. Her new owners, the $P$. and $O$. Co., employed her in their mail service between Southampton and Alexandria. Her career as a Royal Mail steamer was a short one, as she was lost off Cape Finisterre on the 4th February, 1846.

The first great disaster in the Transatlantic steamship trade occurred in the spring of 1841. On the 12th March of that year, the steamship President sailed from New York, bound for Liverpool, with a full list of passengers. She was a new steamer, having been launched fifteen months previously (7th December, 1839) by Messrs. Curling \& Young for account of the British and American Steam Navigation Co., of Bristol. The President was one of the largest and most powerful steamships of her day, her register tonnage being 2,366 tons, and her engines indicated 540 horse-power. On her first voyage, she sailed from Liverpool for New York at 2 p.m. on the 1st August, 1840, arrived at New York 2 p.m. on the 17th idem; sailed from New York 2 p.m. on the 1st September, and arrived at Liverpool 2 p.m. on the 17 th of the same month, being exactly sixteen days on both her westward and her eastward passage. She apparently lay up for the winter, and resumed her sailings in the spring of the following year. She left New York for Liverpool on her third homeward voyage on the 12th March, 1841, having on board 136 passengers. After leaving New York she disappeared, with all her living freight, from human ken. As day after day passed, the utmost anxiety arose, both in the mercantile world and amongst the relatives of the passenger's and seamen, as to the cause of her detention. Other steamers and ships reported very heavy weather in the Atlantic, and the presence of unusual quantities of ice in very 
low latitudes. The newspapers of the period were filled with references to the illfated vessel, with suggestions that her engines had broken down, and that she had drifted out of the track of homeward bound steamers. Multitudinous and conflicting rumours passed into circulation of her wreck having been seen in various places, and a thousand speculations as to the cause and certainty of a catastrophe, and the subsequent fate of those on board, kept alive the agony of those interested in her. Her fate remains one of the sad mysteries of the ocean, as no trace of her wreck was ever discovered, nor a single survivor from the tragedy.

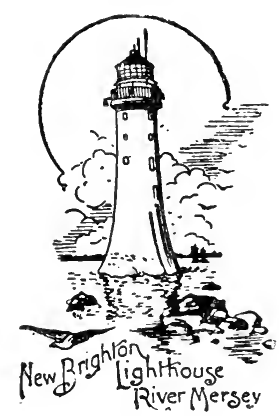




\section{Chapter XIII.}

Mr. Cunard's tender for the carriage of the British and North American Mails accepted, 1839.-Great Britain launched, 1843.-Sails from Bristol for London, 23rd January, 1845.- -Visited by H.M. Queen Victoria.--Sails for Liverponl, June, 1845.-For New York, July, 1845.-Stranded Dundrum Bay, September, 1846.-Floated off, August, 1847.-Sails to New York, 1852.

Ix October, 1838, the British Government, being convinced of the superiority of steamships over sailing brigs, advertised for tenders for the conveyance of the North American Mails by steamers.

Amongst the tenders sent in, that of Mr. Samuel Cunard, of Halifax, was accepted as being the lowest, and in many other respects the most favourable for the public.

With a view of carrying out his scheme for establishing a mail steamship service between England and North America, Mr. Cunard came to London and called upon Mr. Melville, Secretary to the East India Company, to whom he was personally known. From Mr. Melville he received a letter of introluction to Mr. Robert Napier, the celebrated Clyde engineer and shipbuilder, by whom he was introduced to Mr. George Burns, of Glasgow, and Mr. David MacIver, of Liverpool. Both these gentlemen favourably regarded the proposals of $\mathrm{Mr}$. Cunard, and interested themselves so energetically in the matter that in a very short time the whole of the requisite capital for the formation of the Trans-Atlantic Mail Steamship Company was subscribed. A sketch of the history of this famous Company (afterwards known as the Cunard Company) will be found in the second part of this volume.

Although the Britisir Quese had proved an entire success, and was a great favourite with transatlantic travellers, her owners resolved to build a second ship, which would not only exceed her in size, but which should also include all the latest 
improvements the art of naval construction could then command. This was the famous Great Britatr. She was the first Western Ocean steamship constructed of iron, and the first and only one for several years that was propelled by a screw propeller instead of paddle-wheels. She was considered a colossal steamer in her time, and excited quite as much public interest as did the Great Easters at a later period. Her principal dimensions were, length of keel 289 feet, between perpendiculars 296 feet, over all 322 feet, her breadth was 51 feet, depth of hold 32 feet 6 inches, her measurement 2,984 tons, and her engines 1,000 h.p. She originally carried six masts, two of which were forward and four aft of the funnel. She was built at Bristol, from plans furnished by Mr. Patterson of that City, who also had designed the Great Westers. Her engines and boilers were constructed in, and fitted on board the vessel at, the Company's own works, as no outside engineers would undertake the contract. But, owing to an extraordinary oversight on the part of the consulting Engineer, it was then found that she was imprisoned in the dock, being so deeply immersed by the weight of her machinery as to be unable to pass out. Although she was launched on the 19th July, 1843, owing to the above unfortunate mistake, she was not ready for sea until December of the following year. On her passage from Bristol to London she encountered a severe storm which thoroughly tested her seagoing qualities, and through which she passed triumphantly. Her arrival in the Thames was awaited with great interest by the public, whose curiosity had been excited by the numerous references to the vessel published in the daily and illustrated papers. A long and interesting account of this trial voyage, from which the following particulars are taken, was published in the "Illustrated London News," under date of the 1st February, 1845. From this article it appears that the Great Britaix left Bristol for London at $\tau$ p.m. on Thursday, 23rd January, 1845. At the time the ship got under weigh, it was blowing a fresh breeze from the S.S.W., which at 3 a.m. on Friday had veered to the N.W. and increased to a gale, and there was a counter swell from the Irish Channel, causing a disagreeable and heavy cross 


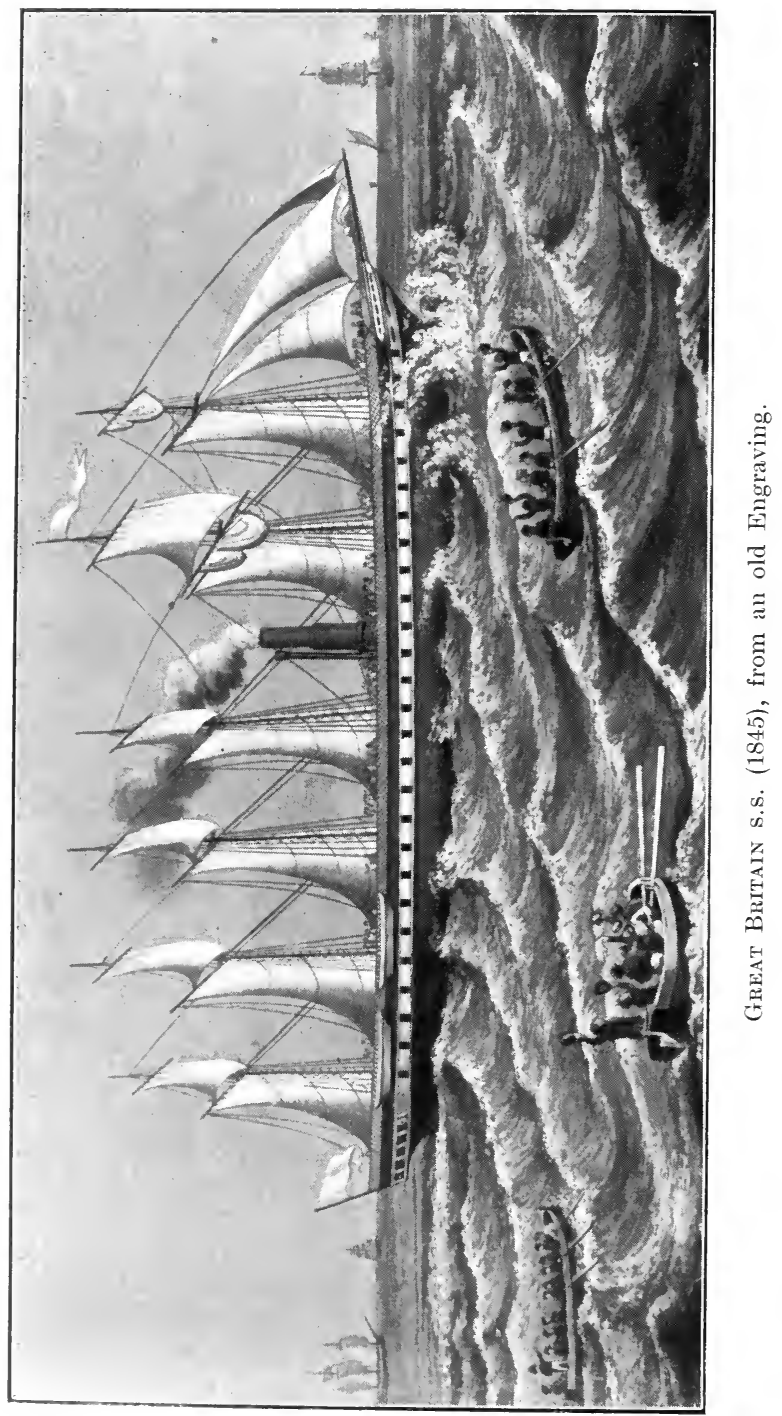


sea. The gale continued to increase, and was for a considerable time on her starboard bow; yet, notwithstanding this, in the face of the gale, and a heavy head sea with a strong ebb tide, she made five and a half knots per hour. At twenty minutes past twelve, when about fifteen miles to the westward of Lundy, she was struck on the starboard bow by a tremendous sea, which must have contained two or three thousand tons of water. The shock for a moment seemed to paralyse the vessel and to bring her to a standstill; this, however, was but for one moment; the vessel recovered the shock instanter, and continued to brave the gale as though nothing had happened to check her progress. Some idea of the force of the concussion may be formed from the damage done to the vessel. Three of her starboard bulls eyes were stove in, together with their frames, the diagonal bends of her forecastle deck were bent, the woodwork started two inches upwards, a portion of the carved figurehead carried away, also the wooden fittings of her bulkhead, the iron sheathing of both bows split above deck in two places. The gale continued until 5-30 p.m., when it became more moderate. At $8-45$ p.m. the GrFat Britain rounded the Land's End, and at 10-40 was off the Lizard proceeding up the Chamnel at the rate of $10 \frac{1}{2}$ knots per hour. The (aptain (Lieut. Hoskins, R.X.), was of opinion that neither the Great Westers, nor any other Royal Mail (Paddle) Steamer, could have made such headway under the same eircumstances by at least from one to one and a half knots per hour.

On Saturday, 25th January, at 12-10 a.m., she was abreast of Falmouth, and proceeded up channel, with light winds from the S.W. at an average speed of 12 knots per hour. At $12-45$ p.m. she entered the Needles passage, and when off Cowes, at 2-15, the engines were stopped to land despatches. At 2-18 again proceeded on her course. C'pon arriving at Spithead, Captain Hoskin took his vessel under the stern of H.M.S. Apolio, fired a gun, and gave her three cheers, which were returned by the crew and troops on board. At 1-40 a.m. on Sunday (26th), the Great Britaix came to an anchor in the Downs, having ran from the time she rounded the Land's End, 
three hundred and fifty miles at an average speed of twelve knots per hour.

At 7-45 a.m. the vessel was got under weigh again from the Downs, and upon rounding the North Foreland, and steering through the Queen's Channel, encountered a stiff gale from the W.N.W. The Great Britais, however, met it in gallant style, and made nine and a half knots against it. As she steamed up the river, the crews of every vessel she passed ran on deck to obtain a view of her, her great length, and her singular appearance with six masts, rendering her an object of considerable attraction. She arrived at Woolwich at 3-30 p.m., and at Blackwall a few minutes later. At both these places there was an immense concourse of people assembled to witness her arrival.

She remained at her anchorage at Blackwall nearly five months, during which period she was inspected by many thousands of the public. On the 22nd April H.M. Queen Victoria, accompanied by Prince Albert and suite, paid her a visit.

The Great Britain left Blackwall on Thursday afternoon, 12th June, 1845. On passing Woolwich it seemed as if the whole population had turned out to behold her. The Dockyard was lined with the Naval and Military officers connected with that depôt, whose cheers were loud and continued. She had on board about eighty passengers, who had embarked for a trip round the coast. After calling at several ports she arrived in the Mersey about 9 o'clock on the evening of Thursday, 3rd July, on which occasion she was anxiously looked for by thousands, the pierheads and every available point on the river being densely crowded. The GrEat BRITaIn sailed on her first voyage from Liverpool to New York on Saturday, 26th July, at 3 o'clock in the afternoon, taking forty-five passengers, and arrived out on the 10th August, at noon. On her return voyage she left New York on the 30th August, having on board fifty-seven passengers and 600 tons general cargo, and arrived at Liverpool on the 15 th September, at 8 a.m. She continued to trade regularly between the two ports, her passenger list steadily increasing, until the $22 n d$ September, 1846 , when she 
stranded in Dundrum Bay, Ireland. She was, at the time of the stranding, on a voyage from Liverpool to New York with 185 passengers. Fortunately the mishap was accompanied by no loss of life. The cause of the disaster is explained by the following resolution passed by the Directors of the Company :"With respect to the occurrences which preceded the stranding "of the unfortunate ship, as explained now by Captain Hoskin, "and by the Report of Captain Claxton to the Secretary, the "Directors are of opinion that the ship was stranded in con"sequence of an error in judgment, into which it appears the "Captain was betrayed through the omission of a notice of St. "John's light in the chart of this year, by which he was " navigating, and of the want of knowlerlge on his part of such "a light having been established, it being to the Directors "obvious that had the light been laid, Captain Hoskin would " have known that the judgment which led him at 8 o'clock to "put his ship in the proper course for the North Channel, " ought to have been persevered in."

The Great Britain remained stranded for over eleven months, but on the 25th August, 1847, she was floated off and towed to Liverpool for repairs. After the completion of the repairs she lay in the Liverpool Dock for about five years, and then made one trip to New York, sailing from Liverpool on the 1st May, 1852. She sailed from New York on the 5th June, and after a rapid passage of 10 days 23 hours arrived in Liverpool on the 16th of that month. From that date she ceased to be connected with the Transatlantic Trade, and her subsequent history is sketched in the chapter devoted to the account of steam communication with Australia.

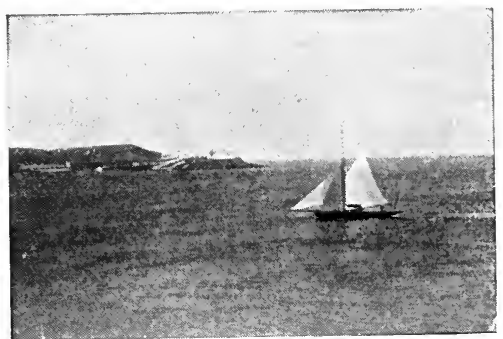




\section{Chapter XIV.}

Steam communication with the West Indies.- Royal Mail Steampacket Co. incorporated 1841.-Commences with a fleet of fourteen steamers.-Heavy loss of first year's working.--Generous concession from Government.-Rapid increase of trade.-The "TRENT affair." - First screw steamers for Company, the Tagus and Mozelle.-The Tasmanian.-Gross tonnage of present fleet.-The Imperial Direct West India Mail Service, Ltd., established 1901.

Nine months after the despatch of the first Cunarder from Liverpool to Halifax, the Admiralty accepted a contract from a newlyformed steampacket company, to convey the mails between England, the West Indies, and the Gulf of Mexico. This company, which bore the title of The Royal Mail Steam Packet Co., had an authorised capital of $£ 1,500,000$, in fifteen thousand shares of $£ 100$ each. It commenced operations on an exceptionally large scale, no less than fourteen large and powerful steamers being at once ordered to be built for the service. The steamers were to be each of 400 horse-power, and to be capable of carrying guns of the largest calibre then in use on H.M. war steamers. Like all other ocean steamers of the period, they were constructed of wood, and were propelled by paddle-wheels. Upon the complete delivery of these vessels to the Company, the contract required one of them to sail twice in each calendar month from England via Corunna and Madeira to the various islands in the West Indies, specified in the contract, and back " to such port in the British Channel as the said Commissioners of the Admiralty shall direct." The scheme also embraced other places in the West Indies, the Spanish Main, and the United States, for which mails were to be carried. For the performance of these services, the Company was to receive a subsidy at the rate of $£ 240,000$ per annum in quarterly payments, the contract to commence on the 1st December, 1841, or if possible earlier, and to continue 
in force for ten years, subject to twelve months' notice from either party for its termination. Notwithstanding this large subsidy, the operations of the Company during the first year resulted in a heavy loss, the Jirectors' balance-sheet, presented at the first meeting of the shareholders, showing a deficit of $\pm \pi 9,79016 \mathrm{~s}$. $8 \mathrm{~d}$. Before this meeting was held, onehalf of the capital had been paid up, and another call of $£ 10$ per share was sanctioned at the meeting; but as it was found that even this was insufficient for the requirements of the Company, the 1)irectors appealed to Government for further assistance. In response to this appeal the Government generously consented to reduce the annual mileage to be traversed by the Company's ships, which by the original contract was 684,816 miles, to $392,9 \pi 6$ miles, without any reduction of the annual subsidy of $£ 240,000$. This liberal concession was estimated by the Directors to effect a saving to the Company of $£ 125,000$ per annum. Unfortunately during the second year of its existence, the Company lost two valuable steamers, which more than counterbalanced the bonus it had obtained from Government. Trade, however, increased so rapidly and profitably, that in the following year (1843) the Company had recouped its losses, and had a surplus of receipts over expenditure amounting to $£ 94,210$, and in 1844 to $£ 14 \pi, \pi 49$.

In 1850 the Government made a fresh contract with the Royal Mail Steam Packet Co. for a further term of ten years from the 1st January, 1852, the subsidy being raised to $£ 2 \tau 0,000$ per annum, but the Company were required to undertake the additional expense of a monthly service to the Brazils, which increased the mileage to be performed annually from 389,448 to $54 \pi, 296$ miles, and at the same time reduced the mileage from 12s. $3 \mathrm{~d}$. to $9 \mathrm{~s}$. 10d. per mile. The Company was also required to increase the speed of its steamers on the West Indian line from 8 knots to 10 knots per hour, and to add five new steamers to its fleet, each of 2,250 tons burden and 800 horse power. This second contract was altered in 185i, and its period of currency extended two years, one condition introduced being of an extraordinary nature. It had reference to 
an amalgamation with the European and Australian Mail (ompany, for the conveyance of the mails via Egypt, to and from Australia. This arrangement proved a great failure, owing to the complete collapse of the latter Company. A second condition required the acceleration of the mails between lingland and Rio de Janeiro. The Company was also required to provide three new steamers of 3,000 tons burden and 800 horse-power for the Atlantic West India service, and a fourth of smaller dimensions to ply between Rio and the River Plate.

In 1864 the second contract expired, and fresh arrangements were made, reducing the amnual subsidy to $£ 172,914$. At the

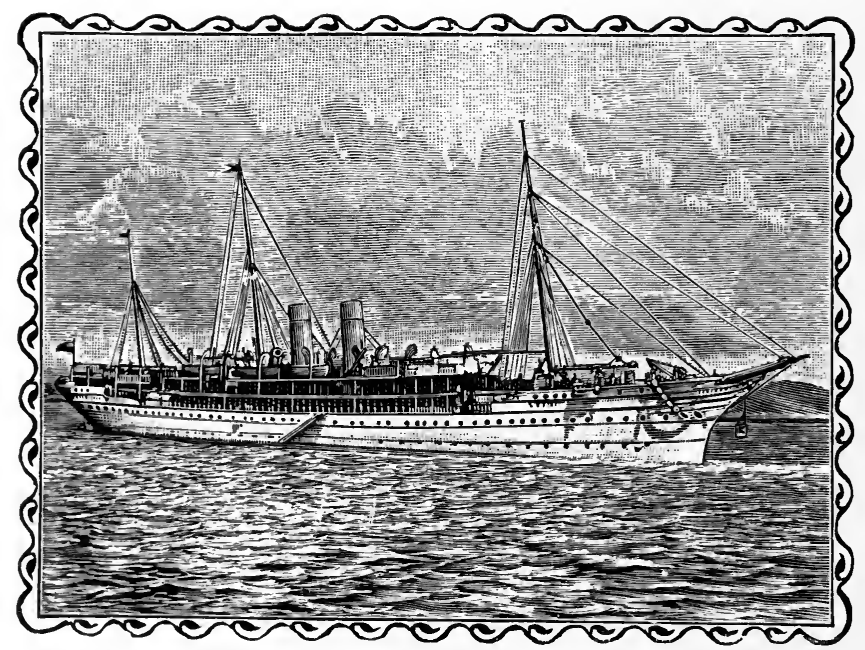

Clyde. Royal Mail Steampacket Co.

same time it was stipulated that the speed of the steamers in the West India Transatlantic service should be increased to 10! linots per hour.

The postal contract was again renewed in 18\%t; but in conseduence of adverse articles and letters which had appeared in the public press, and because several members of Parliament had insisted that the service snould be thrown open to public competition, the Directors of the Royal Mail Steam-Packet Co. found themselves compelled either to abandon the service altogether, or to accept a much smaller subsidy than they had 


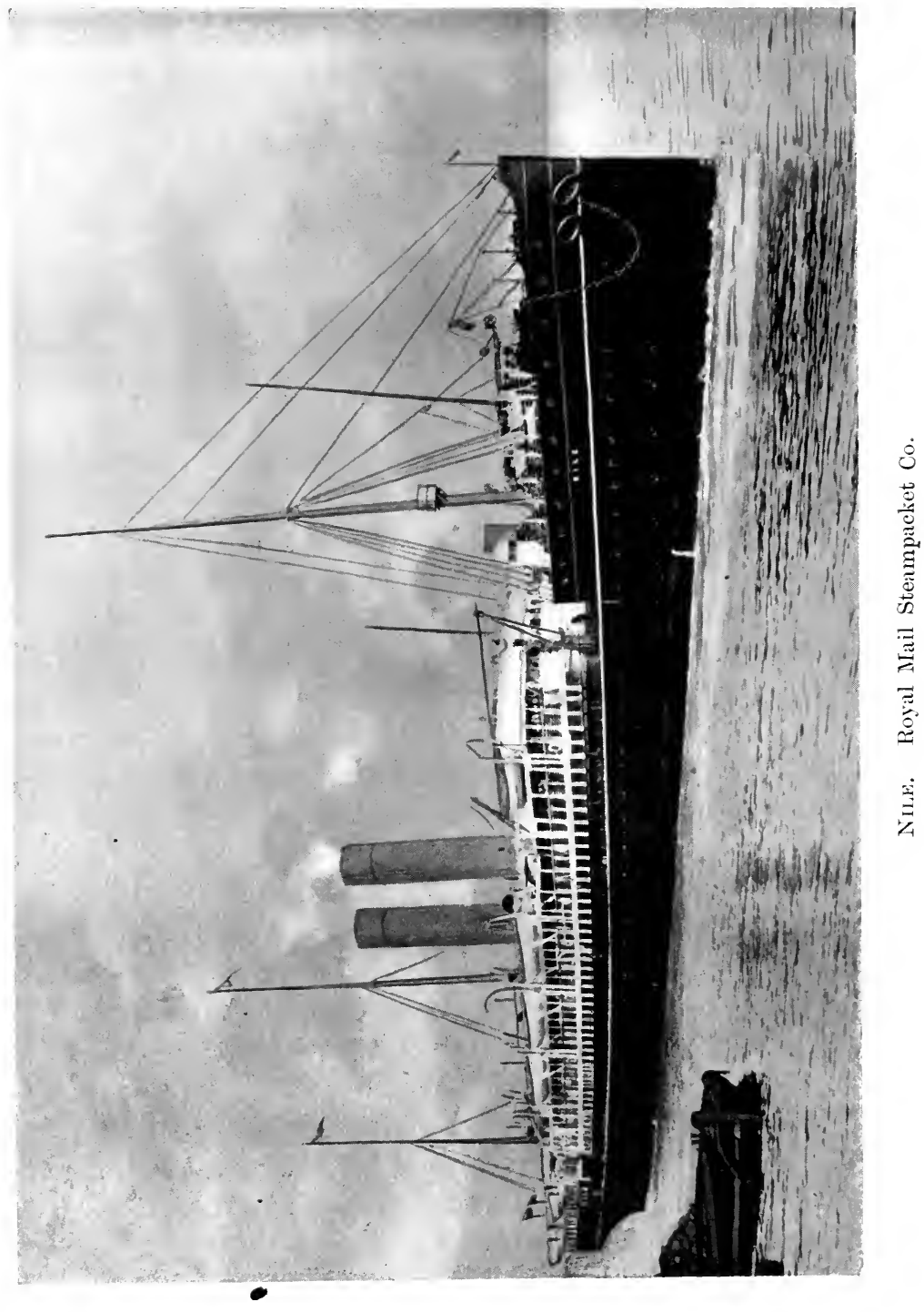


hitherto received for carrying the mails. They adopted the latter alternative, and undertook the conveyance of the West India mails for an annual payment of $£ 84,750$-being about one-third of the amount of the first subsidy. The company in addition received the sum of $£ 2,000$ per annum to cover the cost of the steamers calling at Plvmouth to land the mails instead of carrying them on to Southampton, the final port of destination.

On and from the 1st of January, 1875, the mails were carried on an entirely fresh basis. The contract with the Government was for a service twice a month from Southampton: payment to be according to the weight of postal matter conveyed by the steamers, and the contract was terminable by six months' notice given by either party to the contract.

Although on the North Atlantic screw steamers had been employed in rapidly increasing numbers since 1850 , it was not until twenty years later that the Directors of the Royal Mail Steam Packet Co. substituted screw steamers for paddle-wheel steam packets in their service.

The first fleet of the Company consisted of vessels built of wood, but so indeed were the pioneer steamers of the Cunard, P. \& O., and other historical steamship companies. The course taken by the Company's vessels was free from the dangers from ice and fogs, such as are encountered by steamers engaged in the North Atlantic trades, yet during the first eight years of the Company's operations it lost no fewer than six of its steamers. The Isis struck on a reef off the coast of Bermuda and sank on the 8th October, 1842. The Solway was lost 20 miles west of Corunna on the 15th April, 1843. The Mediva was wrecked on a coral reef near 'Turk's Island on the 12th May, 1844. The 'Tweed was totally lost on the 12th February, 1847 ; and in 1849, the Forti was wrecked on the same reefs that had caused the destruction of the Tweed. The Actжon was lost in 1850 on a shoal near Carthagena; and in 1852 there was lost by fire the Amazon.

An event occurred on the 8th November, 1861, which occasioned considerable public excitement, both in Great Britain and in the U.S.A. It was during the struggle between 


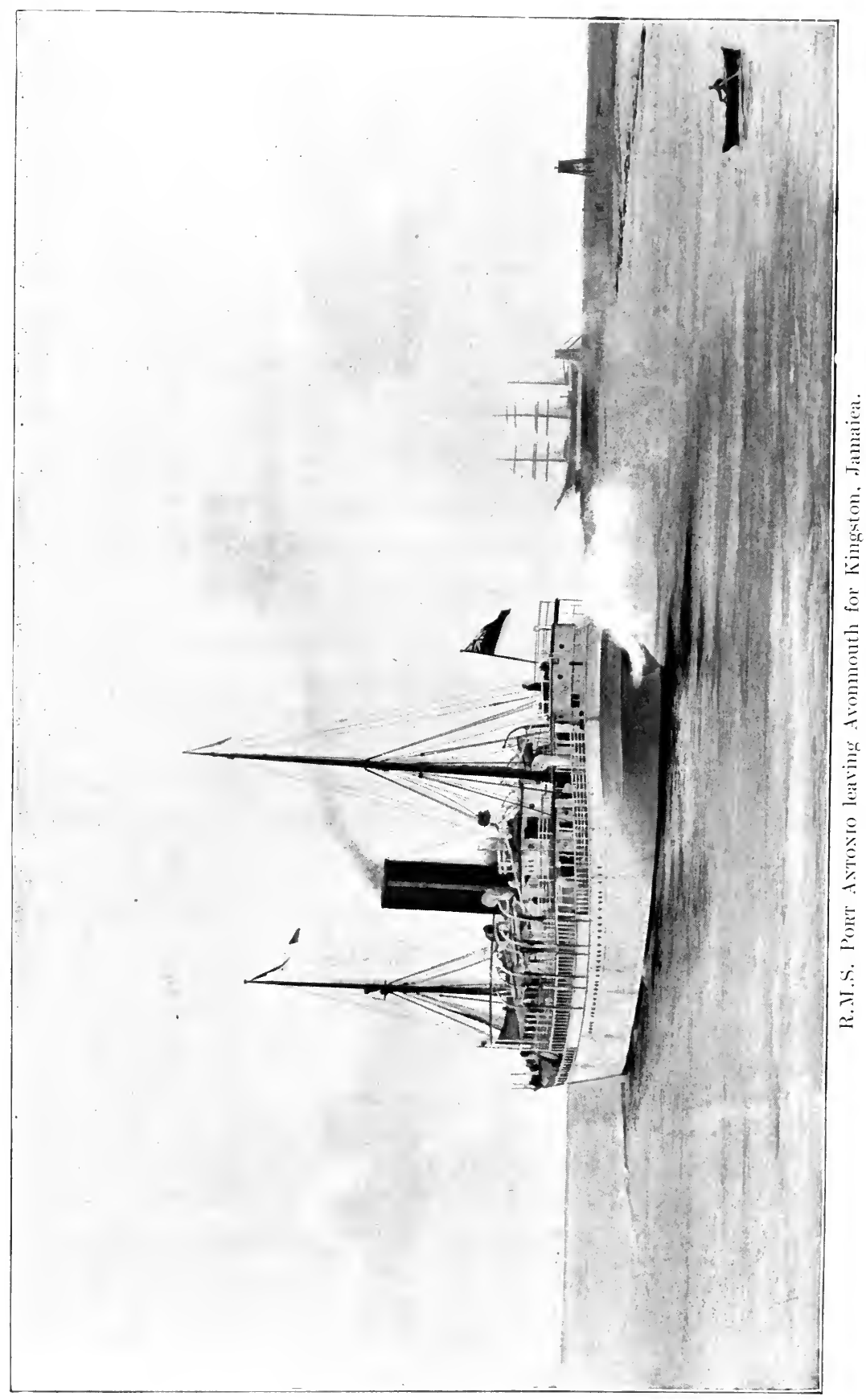


the Northern and Southern States, and two of the Commissioners of the Confederate States were forcibly removed from the Royal Mail steamer Trent, while on their way to Europe, by the officers and crew of the Federal man-of-war $S_{A x}$ JAcisto. This high-handed action, which was not repudiated by the Federal Government, was inexcusable, and the tone adopted by a great portion of the press of the Northern States was ludicrous, and unworthy of a great people.

In 18 i1 there was launched from the yard of Messrs. John Elder \& Co. two splendid screw steamers to the order of the Royal Mail Co. These steamers were the Tagus and the MozkLle, both steamers being 3,252 tons gross register and (i00) nominal horse-power. On her official trial trip the Tagus attained an average mean speed of $14.8 \% 8$ knots per hour, a result which was slightly surpassed by her sister ship the Mozklle, the average mean speed of the latter on her trial trip being 14.929 knots per hour.

It the same time Messrs. Elder \& Co. effected an extraordinary improvement in the Tasmaniax, an iron screw steamer the Royal Mail Co. had purchased from the unfortunate European and Australian Steam Navigation Co. This ressel was fitted with compound engines, and on her first royage afterwards from Southampton to St. Thomas, occupying 14 days 2 hours, she consumed 466 tons of coal, against her' former consumption of 1,088 tons on a voyage occupying 14 days 13 hours.

Since that date all the additions to the Company's fleet have been screw steamers, and it now (1903) consists of 22 ocean steamers, with a gross tonnage of 87,855 tons, in addition to 9 coast steamers employed as feeders to the mail services.

In the first year of the present century, Messrs. Elder, Dempster \& Co. established a service of mail steamer's between Bristol and Jamaica. I detailed account of this service, which is known as the Imperial Direct West India Mail Service, Limited, will be found in the second part of this volume. 


\section{Cinapter xV.}

International rivalry in the Transatlantic. - The Collins Line and the Cunard Co.

Fon upwards of nine years Great Britain had held a monopoly of the transatlantic steamship business. Ameriea could and did build sailing vessels that were unsurpassed by those belonging to any other nation; her Baltimore clippers, Boston packets, and New York liner's were all of them vessels of the highest class and reputation. But apparently Americans could neither build, nor own ocean steamers that were capable of successfully competing with British owned steamships. At least, it is a matter of history that from 18.38 to $184 \pi$ all the steamships that crossed the North Atlantic sailed under the British flag, with one exception.

On the 15th September, 1845, Messrs. Forbes \& Co. despatched from New York their auxiliary steamship Massacinserts. She was practically a full-rigged ship, 051 tons O.M., fitted with an engine of 160 horse-power. This engine had two cylinder's each 3 feet stroke and $2(;$ inches diameter. steam was generated in two "waggon boiler's," each 14 feet long, 7 feet wide and 9 feet high. Her propeller was made of composition metal, and could be raised out of the water when not required. Her engine room, boiler's, bunkers, \&e., were situated in the lower after hold, and oceupied a space equal to one-tenth of the eubic eapacity of the ship. Her engines were capable of driving her in smooth water at the rate of about $s$ knots per hour, on a consumption of 9 tons anthracite coal per 24 hours. The length of the Massaciusetrs was 161 feet, her beam 31 feet 9 inches, and her depth of hold 20 feet. She had a full poop, extending to the mainmast (and consequently forward of the funnel), in which there was accommodation for 35 first-class passengers. Her entire cost with machinery com- 
plete in all respects was $£ 16,000$. She made two round voyages between New York and Liverpool, and in June, 1846, was chartered to the U.S. Government to carry troops to the Gulf of Mexico. The Government were so well pleased with her that they afterwards purchased her, and she took part in the siege of Vera Cruz. Subsequently her name was changed to the Farralones, and she continued in the U.S. Navy until about 18\%0, when she was again sold. Her new owners removed her machinery and renamed her the Alaska.

Obviously the Massaciudsetts was not intended to compete against full-powered ocean steamships, and it was not until $184 \pi$ that the first American line of steamers to Europe was established. This was a line of steamships to run between New York and Bremen, calling at Southampton. The pioneer steamer of the line, the Washington, sailed on her first voyage from New York for Southampton on the same day (June, 1847) that the Britannia, belonging to the Cunard Company, sailed for Liverpool. This was the first ocean race between American and British steamships. Theoretically the American steamer was incomparably superior to the other. She was much larger and had double the power; she was new, while her rival had been buffeted by the Atlantic billows for seven rears. Quoth the editor of the "New York Herald": "We have to say that if the Britannia beats the Washivgton over (and they both, we understand, start the same day), she will have to run by the deep mines, and put in more coal." The Britaxia did not "run by the deep mines and put in more coal," but she won the race by two full days.

Great pressure was subsequently brought to bear on Congress in order to obtain a subsidy for an American mail service to Great Britain. Those in favour of the subsidy argued that it was humiliating to their pride as a great maritime people, that foreigners and commercial rivals should wrest from them the virtual monopoly of ocean steam conveyance, especially between the United States and Europe, and they complained that the ocean mails along their southern coasts had been placed in the hands of foreign carriers, sustained and protected by the British Government under the forms of contract to 


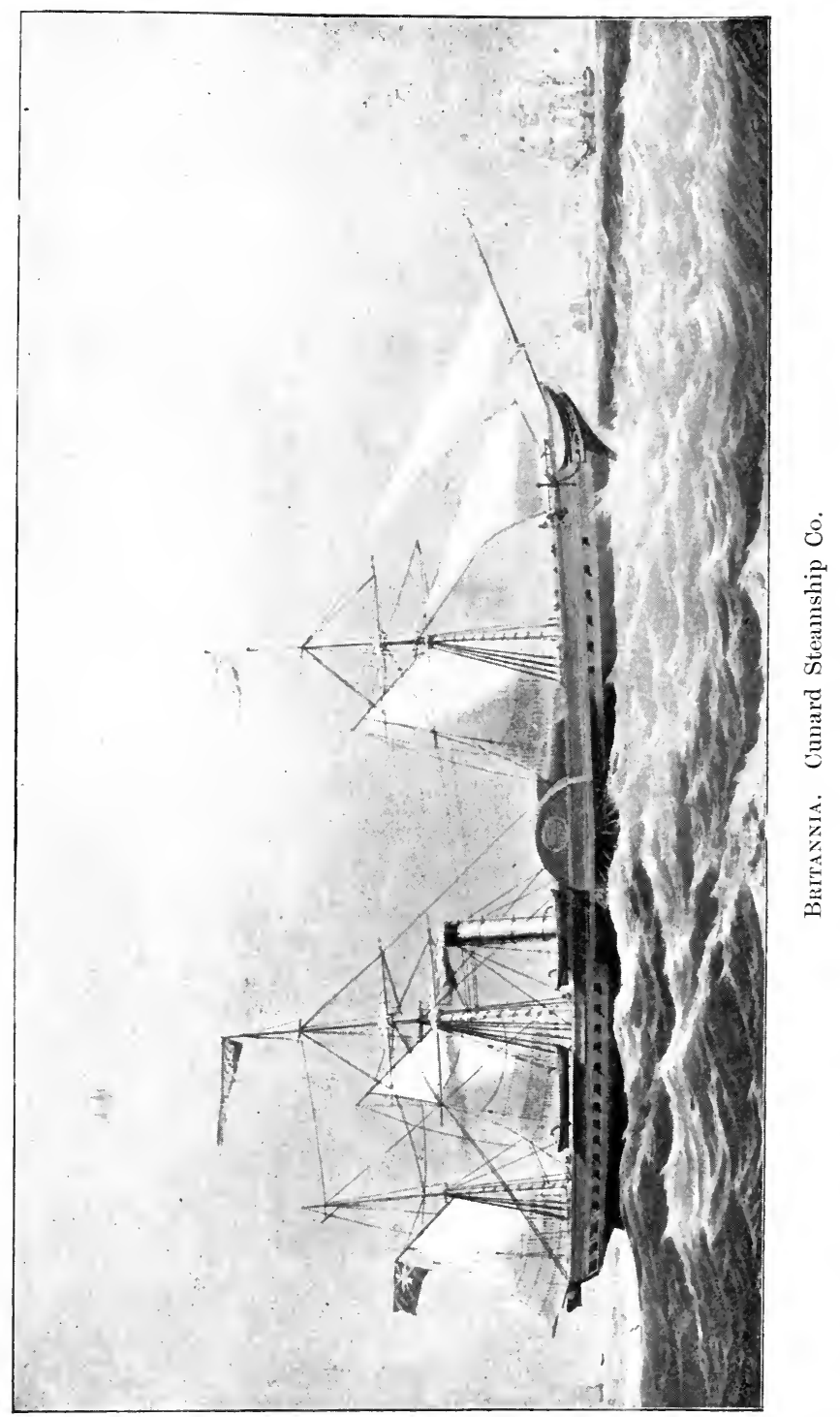


carry the British mails; while the Cunard Line, between Liverpool and Boston, via Halifax, constituted the only medium of regular steam navigation between the United States and Europe.

It may be appropriate to state here, that in aldition to carrying the British mails from Liverpool to North America, the Cunard Company, early in 1850, obtained a contract from the British Government for the conveyance of the mails between Halifax, New York and Bermuda. The steam packets employed in this service were the Alpha, Beta and Drata, small vessels each of 350 tons and 80 horse-power, and fitted with a proper space for mounting an 18 -pounder pivot gun. The arrangements for carrying on the service were as follows: -Twenty-four hours after the arrival of the packet from Liverpool, one of these vessels left Halifax for Bermuda; at the same time another left for St. John's, while the third conreyed the mails monthly between Bermuda and New York. The payment for these services amounted to $£ 10,600$ per annum, equal to 3s. per mile, while on the main line it was 11s. 4d. per mile. The following year the British Government made another contract with the Cunard Company for a monthly conveyance each way of the mails between Bermuda and St. Thomas, upon such days as might be fixed by the Admiralty, the one vessel engaged in it being in all respects similar to those engaged in the Halifax and Bermuda service. The amount of subsidy was $£ 4,100$ per annum, or equal to 4 s. per mile. This service connected the West Indies with the United States and the North American provinces.

Following the example of the British Government, the Tnited States Congress resolved to subsidise a line of American steamships between New York and Liverpool. The steamers were to be of the highest class, possessing great speed and superior passenger accommodation, and capable, besides, of being converted at a small expense into war steamers. The responsible task of establishing the line was undertaken by Mr. IE. K. Collins, of New York, after whom the line was named. Mr. ('ollins had had considerable experience as a shipowner, heing well-known as the head of the Collins Line of 
sailing packets between Liverpool and New York. Associated with Mr. Collins in his later enterprise were many influential American citizens, and their proposals were favourably received by the American Government, and ultimately an agreement was entered into, by which Mr. ('ollins and his colleagues undertook to provide five first-class steam vessels and to maintain a weekly mail service between New York and Liverpool, each vessel performing twenty voyages annually, for which service they were to receive $\$ 19,250$ per voyage. It is evident that the United States Government were prepared to pay most liberally for the performance of the ocean mail service. At par the subsidy represented $£ 4,0108$ s. 4 d. per voyage. Assured of this substantial income, Mr. Collins sought the assistance of the most competent shipbuilders and engineers of the United States, and on the completion of the contract, arrangements were entered into for the construction of four ressels, to be named the Arctic, Baltic, Atrantic and Pacific, each to be about 3,000 tons register and of 800 horse-power. The principal dimensions of these celebrated steamers were-Length on main deck, 282 feet; depth from the main deck, 24 feet; depth under the spar deck, 32 feet; breadth of beam, 45 feet. They had rounded sterns, three masts with suitable spars; four decks, viz., lower, main, spar, and orlop deck, extending from the engine room forward and aft. They were built chiefly of live oak, planked with pitchpine, and were equal, if not superior, in strength to any wooden steamers afloat. The timbers, which were solid and bolted to each other, were further strengthened by a lattice work of iron bands. All the four steamers were beautiful models, and the Arctic, which was esteemed the finest of the fleet, was familiarly known as the "clipper of the seas." She was built by Mr. W. H. Brown, of New York, under the superintendence of Mr. George Steers, who modelled the famous yacht America. Her equipment was complete, and of the highest order, while her cabin accommodation surpassed in comfort and elegance any merchant steamer Great Britain then possessed. The engines of the Arctic and her sister ships were of the "side-lever" type, the cylinder having a diameter of 95 inches, with a 9 feet stroke. The 
boilers of the Arctic and BaLTic were peculiar to the Collins Line, and were designed by Messrs. Sewell and Faron, chief engineers of the United States Navy. The latter of these two gentlemen acted as chief engineer of the Company. The boilers were arranged with double furnaces, and lower water spaces connected by a row of vertical tubes, around which the heated gases circulated, with a hanging bridge or plate, which checked their otherwise rapid flow to the funnel, and rendered the combustion more perfect. The average consumption per 24 hours by the Arctic was 83 tons anthracite coal, attaining an average speed of 316.4 knots per day. Her maximum consumption was $8 \tau$ tons, with a speed of 320 knots in 24 hours.

These vessels were constructed so utterly regardless of expense that to complete them it was found the cost would be very greatly in excess of the estimates. The Government was therefore appealed to for assistance. The appeal was generously responded to. The United States Government not only made an advance to the Company while the ships were being built, but also released it from its obligation to build a fifth vessel as originally contemplated, and increased the subsidy from $\$ 19,250$ to $\$ 33,000$ per voyage. But for these benefits increased speed was demanded. "We must have speed," declared Mr. Bayard, during the debate in Congress, " extraordinary speeda speed with which they (the Collins steamships) can overtake any vessel which they pursue, and escape from any vessel they wish to avoid; they must be fit for the purpose of a cruiser, with armaments to attack your enemy (if that enemy were Great Britain) in her most vital part, her commerce." Happily the contest was a commercial and not a national one, and the Collins steamers were never required for the purposes of $\mathrm{Mr}_{\mathrm{r}}$. Bayard's hypothesis. They did, however, engage (and for a time with apparent success) in a great contest with the Cunard Company for the commercial maritime supremacy of the Atlantic.

The Atraxtic, the first of the Collins Line of steamers to cross the ocean, arrived at Liverpool on the 10th May, 1850. The breadth of beam of this vessel and her sister ships was so great that they were unable to enter any existing docks at 


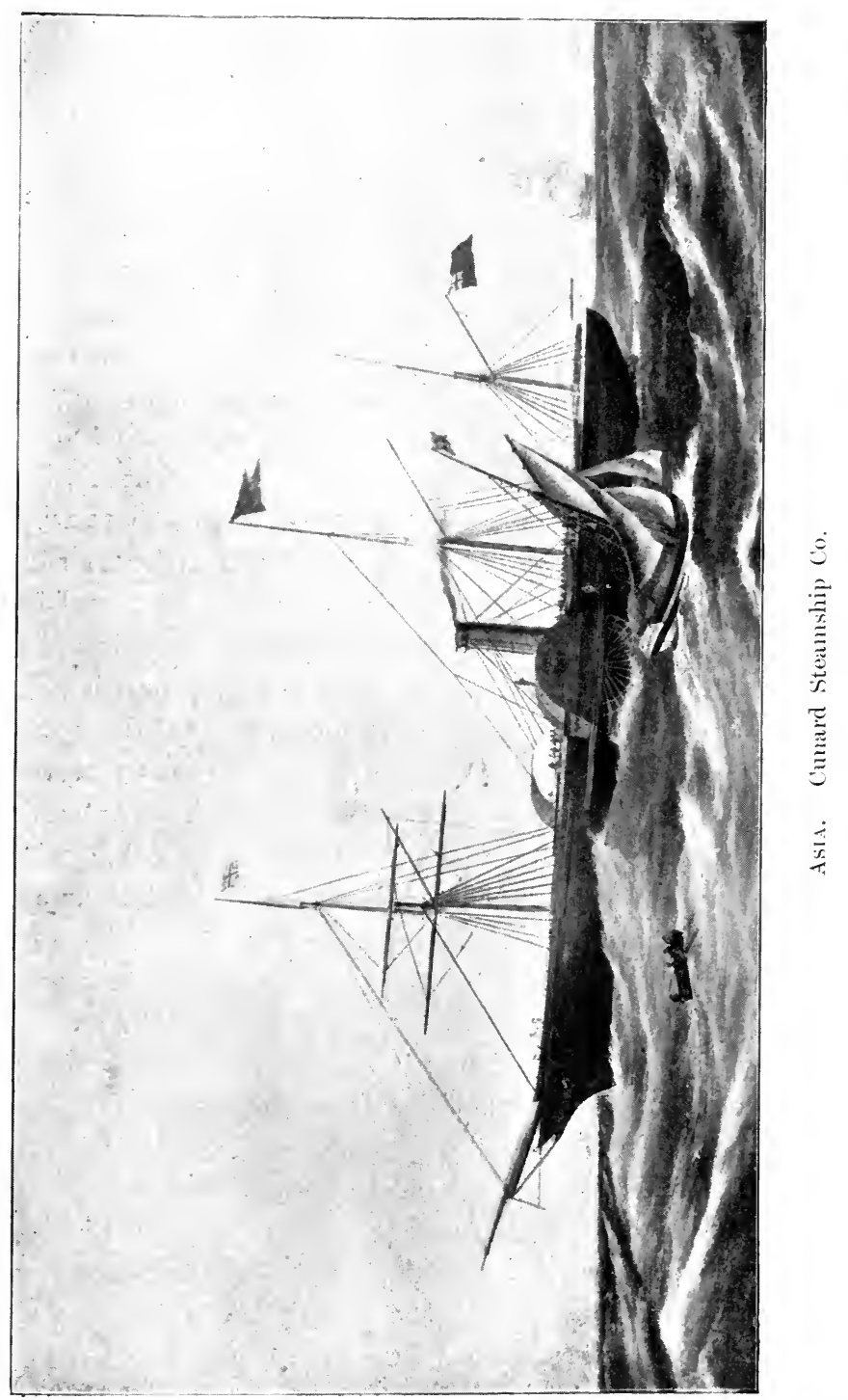


Liverpool, and a dock at the north end of the port was constructed specially for their accommodation. The arrival of the ATLAxTic excited very great interest, which was increased rather than lessened by the presence at Liverpool of the Asia R.M.S., just built for the Cunard Line, and which left for New York on the following Saturday week.

The following description* of the interior decorations of the ATLANTIC may be taken as a general description of the whole of the Collins steamers, and will be read with interest:-

Her saloon is 67 feet long by 20 feet wide. Her interior fittings are truly elegant, the woodwork being of white holly, satinwood, rosewood, \&c., so combined and diversified as to present an exceedingly rich and costly appearance. In the drawing room the ornaments consist of costly mirrors, bronzework, stained glass, paintings, \&c. Between the panels connecting the staterooms are the arms of the different states of the confederacy painted in the highest style of art, and framed with bronze-work. The pillars between are inlaid with mirrors, framed with rosewood, and at the top and bottom are bronzed sea-shells of costly workmanship. In the centre of each are allegorical figures representing the ocean mythology of the ancients, in bronze and burnished gold. The ceiling is elaborately wrought, carved and gilded. The cabin windows in the stern are of painted glass, having representations of New York, Boston and Philadelphia painted on each. There is in addition another apartment equally beautifully arranged and ornamented, for the exclusive use of ladies. Both apartments are heated by steam, an improvement now for the first time introduced in steamships. The dining room (60 feet long) is furnished in an equally elegant style with the drawing room. The staterooms, which are light and airy, are beautifully furnished and ornamented, and combine every convenience that practical science and experience could suggest. It would occupy more space than can be spared to detail the magnificence of the furniture of the ATLANTIC; the carpets are of the richest description; the table-slabs are of Brocatelli marble. 
Each stateroom has an elegant sofa; the berths are of satinwood, and the curtains of rich damask.

The Atrantic left New York on the 27th April, 1850, with nearly a hundred passengers, and a valuable cargo, under the command of Captain West. Shortly after leaving Sandy Hook she got entangled amongst some drift ice, which did considerable damage to her floats. This mishap was a serious drawback to her, inasmuch as the engines had to be worked at a reduced rate to prevent the floats from being torn from the wheels altogether, and the weather was too boisterous to admit of them being repaired. During the five succeeding days, the noble vessel continued to prosecute her voyage to the satisfaction of her captain and all on board. On the 3rd May, however, an accident of a more formidable nature occurred, one of her condensers giving way. After a fruitless attempt to adjust the machinery, the vessel having been hove to forty hours, Captain West decided to pursue his course, the steam being kept at a low point in consequence, which considerably retarded the vessel's progress during the remainder of her passage.

The American steamers were swifter than their British rivals, and for a few years were the favourites with the travelling public. According to a return published in the "New York Herald" on the 1st January, 1853, the number of passengers carried during the eleven months .January to November (inclusive), 1852, were:-

By Collins Line, New York to Liverpool

2,420

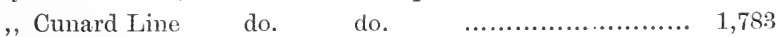

,, Collins Line, Liverpool to New York ...................... 1,886

,, Cunard Line do. do. $\quad$..................... 1,186

It will be noticed that the majority of passengers carried were from New York to Liverpool, the explanation of this unusual circumstance being that it was at the time of the great rush to the Australian goldfields, when it was no uncommon thing for a Melbourne packet to sail from the Mersey with from five to six hundred passengers. Nor were the receipts from passage money the only source of revenue available for the Collins steamers. They were loyally supported by American shippers and importers, and the receipts from freight were 
large, although the rate on fine goods had been lowered from Łٔ 10 s. to $\mathfrak{t}+$ per ton.

Notwithstanding the large income derived from these sources, the service was only maintained for a period of about ten years. The heavy disbursements and the numerous casualties which befell the steamers, especially the loss of the Arctic (as narrated in the following chapter) and of the PAcific, with all on board, led to the collapse of the company.

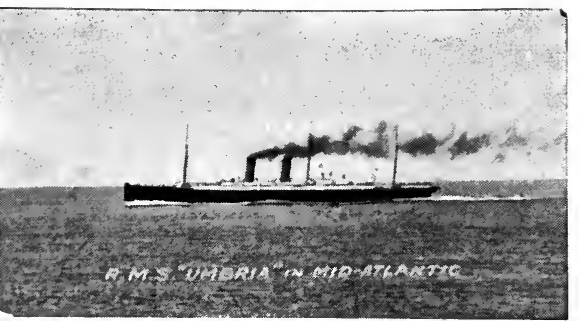




\section{Chapter XVI.}

The Loss of the Collins Liner Arctic.

Ox Wednesday, 2rth September, 1854, about noon-Cape Race bearing S.W. by W., 65 miles distant-the steamship Arctic, on her passage from Liverpool to New York, while running through a very thick fog, was struck on the starboard bow about 60 feet abaft the cutwater by an iron steamer. The force of the impact made three large holes in the Arctic - two below the watermark, one of which was about $5 \frac{1}{2}$ feet in length and about $1 \frac{1}{2}$ feet broad. The fog was so dense that neither vessel saw the other a minute before they collided.

The passengers on the ARcTic were at lunch when their vessel was struck, and they immediately rushed on deck. Through the dense fog could be seen very indistinctly on the starboard bow a screw steamer, which was afterwards found to be the French merchant steamer VEsta. No apprehension of danger was felt by those on board the Arctic, and a boat in charge of the chief officer was sent off to the rescue of the passengers and crew of the other steamer. On board of the Vesta no hope was entertained of her ultimate safety, the crew and passengers relying upon being taken off by the crew of the Arcric. When the collision occurred there were several men on the bow of the Vesta, presumably on the lookout, one of whom was killed and the others severely wounded. As it was feared that the steamer was sinking, a rush was made for the boats, and two were launched. The first boat was swamped, but the second boat floated, and was at once boarded by several of the passengers and two of the crew, who, ignoring the captain's orders to return on board, cut themselves adrift, and abandoned their shipmates. While these occurrences were taking place on the deck of the Vesta the Arctic had disappeared in the fog, those on the Vesta still hoping, however, that she had not deserted them. Meantime, 
the officers on board the Arcric had discovered that there was little hope of saving their vessel. Mrs. Collins, the wife of the managing owner, with their daugitter and son, were passengers, and the captain's first thought was for their safety. They and several ladies were placed in a lifeboat, but while it was being lowered one of its tackles gave way, and all, with the exception of one lady who clung to a sailor holding fast to the boat, were east into the sea and drowned. $A$ second boat was lowered successfully, and stored with provisions. It was soon filled with passengers-ladies and gentlemen-but by a strange oversight on the part of the officer in charge none of the crew aceompanied them.

The difficulty and danger of lowering the boats was greatly increased in consequence of the impossibility of stopping the ship for that purpose, the pumps having been attached to the main engines in the attempt to keep the vessel clear of water, which was pouring into her through the breaches in her side. Cape Race being within about four hours steaming distance, she was headed in that direction, but after running about fifteen miles the water had risen so high in the stoke-hole as to extinguish the fires, and, in consequence, the engines ceased to work. Almost immediately after the ship stopped, the remaining lifeboats left the ship. There was one large boat on deck, which was capable of carrying fifty persons, but there were not sufficient seamen left on board to launch her, and it is supposed that she was filled with passengers in the hope that she might float off when the steamer sank.

In the Annual Register for 1854, it is stated that Captain Luce and most of his officers exerted themselves with firmness and energy while a hope remained, and the former probably owed his life to his remaining at his post. When his steamer sank he clung first to some floating wood, and afterwards got on a floating paddlebox, on which eleven others had taken refuge, of whom nine were swept away by the sea, the three survivor's being reseued by the Cambria, of Glasgow. The captain's son was killed in his father's arms by a piece of wreck.

The conduct of Captain Duchesne, of the Vesta, was most praiseworthy. Finding that the ARCrIc had disappeared in 
the fog, and that his own vessel had not sunk under him, he, with the utmost promptitude, took measures for saving his ship and passengers. He noticed that, although the steamer's bows were completely shattered, the forecastle bulkhead had not given way, and this aftorded some hope of safety. He at once gave orders to lighten the vessel by the head, by throwing overboard all the fish, cargo, passengers' luggage, \&e., which was in the forepart of the ship, all of which orders were promptly obeyed, and by means of which the vessel's bows were raised considerably. Her head was raised still more by cutting away the foremast, which had been damaged by the collision. The captain next ordered about 150 mattresses, palliasses and other eftects belonging to the crew and passengers to be placed abaft the forecastle bulkhead, over which were thrown sails, backed by boards and planks, the whole being secured by cables firmly wrapped round all.

These operations occupied two days, after which Captain Duchesne proceeded under easy steam for the nearest port (St. John's), which was entered on the 30th September. Most providentially, considering the disabled condition of the VEsT, she entered the harbour of St. John's before the rising of a severe gale, which sprang up on the same day. The energy, unwavering perseverance, and superior seamanship exhibited by Captain Duchesne in bringing his vessel into port, elicited the admiration and praise of all who visited the ship.

The American Consul at St. John's made every exertion to procure vessels to go at once in search of the Arcric or her boats. He succeeded in obtaining the brigantine ANx ELiza, whose owners (Messrs. Warren Bros.) generously gave her without charge. She sailed from St. John's on the 2nd October, with instructions to cruise in the vicinity of the catastrophe for three days.

The Right Rev. Dr. Field also promptly placed at the disposal of the American Consul his yacht, the Hawk, for the same purpose.

The last moments of the Ancric are thus graphically described $^{*}$ by Mr. Baahlam, the second officer of the steamer:- - 
". In about thirty minutes all the lower fires were out, " and, at the least, there were six feet of water in the "ship fore and aft. By this time the confusion amongst " the passengers was very great, but ther used all efforts " to assist the crew to keep the pumps going, and in "lightening the ship forward for the purpose of getting " at the leak from the inside, which we found to be use"less, and numbers of them got into the boats, which " were still hanging to the davits. In forty-five minutes "after the collision I came up from the forehold, and " informed the captain that the water was on a level with " the lower deck beams, and that it was impossible to get " at the leak. I then asked him what he thought would "be the probable fate of the ship, when he stated his " belief to me that there was no hope of saving her. He " then told me to see to my boats. On going to those on " the port side I found them completely filled with men " and women, and no possibility of getting near them. "I immediately went to the starboard side and ordered " two of the crew to lower the guard boat, and asked the "captain what his intentions were, who replied that the "ship's fate would be his. I then asked him if he would " not allow his son to go with me, as I intended to take a "boat, but he returned me the answer that he should " share his fate. I then jumped into the boat, and was " ordered by the captain to cut away the tackle falls, and "drop under the stern. I did so; at which time about " twenty persons, as I suppose, jumped overboard, of " whom seventeen or eighteen were picked up. I fell in "with another boat which had been lowered from the " other side, and lightened her of part of her complement, "leaving nineteen in her, and twenty-six in my own boat. "The last sight we had of the ship her guards were level

" with the water, and the surface of the sea strewed with

"human beings, who had jumped or fallen overboard"to whom, however, it was impossible for us to render " any assistance; and we soon lost sight of all, as the fog " continued very dense. I then asked the boat's crew "whether they were willing to be governed by me, which 
“was unanimously approved, and I was put in complete " command of both boats.

"We were then about sixty miles S.E. of Cape Race.

"Deeming it my duty, for the safety of all, I took the

" nearest course for the land, and, after pulling forty-two

" hours, with nothing to guide us but the run of the sea,

" which I took to be heaving from the southward, and in

" a thick fog which lasted all the time, we reached Broad

"Cove, some twelve miles North of Cape Race."

The Arcric, when she sailed from Liverpool on this illfated voyage, had 365 souls on board, of whom only 87 were saved. The hull, machinery, and equipment of this steamship were insured for $£ 115,000$, as follows:-Underwritten in the United States, $£ 55,000$; in London, $£ 40,000$; and in Glasgow, 220,000 .

The Vesta, which sailed from St. Peter's the day previous to the collision, had $19 \tau$ persons on board, viz., a crew of 50 men and 147 pasengers; of these 13 were reported missing when she arrived at St. John's.

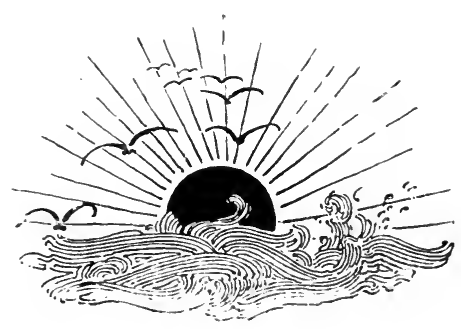




\section{Cilapter XVil.}

Steamship Companies of the past.---Inman Line.--National Line.--Guion Line.-Royal Atlantic Steam Navigation Co.

Is the early spring of 1850 Messrs. Tod and MacGregor, iron shipbuilders and engineers, Glasgow, launched the iron screw steamer City of GlasGow, a vessel of 1,600 tons and 350 horsepower. During the spring and summer of that year she made several royages between Glasgow and New York, but in the latter part of the year she was purchased by the Liverpool, New York and Philadelphia Steamship Company, and sailed from Liverpool to Philadelphia on the 1rth December, 1850. This ressel was the pioneer of what is better known as the "Inman" Line. This ill-fated vessel left port on 1st March, 1854, with four liundred and eighty persons on board, and was never again heard of. In 1851 the Inman Company purchased the steamship City of Manchester, built also by Tod \& MacGregor. Her registered tonnage was 2,125 tons; her length 274 feet, and her breadth 38 feet. She had a clipper bow and bowsprit, four masts square rigged on the fore and main masts, with her funnel between the main and mizzen masts. Other iron screw steamers, all having the beautiful clipper bow for which this line was noted, were quickly added to the fleet, comprising the Kangaroo, City of Baltimore, City of Washington, City of Boston, City of Bristol, City of Limerick, City of Lincoln, ('ity of London, City of Durifam, City of New York, City of Paris, City of Antwerp, City of Brooklyn, City of Brussills, City of Montreal, City of Cinester, City of ('incago, City of Richmond and City of Berlin.

Juring the first five years of its existence, the Inman Company maintained a fortnightly service between Liverpool and Philadelphia, but in 1857 it enlarged the area of its operations by making New York one of its ports of arrival and by estab- 
lishing a fortnightly line thither. On the collapse of the Collins Line, Mr. Inman at once assumed their dates of sailing, and increased the service to once a week, and was appointed to earry the United States mails between England and America. Nor were the Inman steamers, though screws, less swift than their predecessors. Their later steamers far surpassed the swiftest steamers of the Collins Line, and one of these, the City of Paris, in 1869 conveyed H.R.H. Prince Arthur to America in six days twenty-one hours, the quickest passage (up to that date) ever made to any port of the New World from Cork.

Mr. Inman specially directed his attention to the conveyance of emigrant passengers across the Atlantic, and he and Mrs. Inman, greatly to their credit, made a voyage in one of their earliest emigrant steamers, expressly for the purpose of ameliorating the discomforts and evils hitherto but too common in emigrant ships. The following table shows how successful he was in catering for the emigrant passenger trade :-

\begin{tabular}{|c|c|c|c|c|c|c|}
\hline Passenciers Lan & $\mathrm{DAT}$ & $\begin{array}{l}\text { New } \\
\text { IN }\end{array}$ & $\begin{array}{l}\text { YORK FR } \\
1870:-\end{array}$ & & THE UNited & D Kixgidon \\
\hline $\begin{array}{c}\text { Line. } \\
\text { Inman .......................... }\end{array}$ & $\begin{array}{c}\text { Trips. } \\
68\end{array}$ & $\ldots$ & $\begin{array}{c}\text { Cabin } \\
\text { Passengers. } \\
3,635\end{array}$ & ... & $\begin{array}{c}\text { Steerage. } \\
40,465\end{array}$ & $\begin{array}{l}\text { Total. } \\
44,100\end{array}$ \\
\hline National ................ & 56 & $\ldots$ & 2,442 & $\ldots$ & 33,494 & 35,736 \\
\hline Guion ..................... & 55 & $\ldots$ & 1,115 & $\ldots$ & 27,054 & 28,569 \\
\hline Anchor.................... & 74 & $\ldots$ & 1,637 & $\ldots$ & 23,404 & 25,041 \\
\hline Cunard................... & 70 & $\ldots$ & 7,638 & $\ldots$ & 16,871 & 24,509 \\
\hline
\end{tabular}

Of the ressels named in the preceding page the Citr of Washington and City of Boston met with the sad fate that overtook the President and the Pacific. They sailed, but never reached the desired haven, and in course of time were posted "missing." Two of them, the City of London and the City of Limerici, were sold to Messis. W. H. Ross \& Co., and sailed for some time between London and New York. The City of Axtwerp was purchased by Messis. William Johnston and Co., who changed her name to Thanemore and employed her for several years in their Liverpool and Baltimore trade. By a strange fatality, each of the three steamers last named, sailed from its respective port and was never afterwards heard 
of. The first two disappeared in 1881, and the third in 1890 . The City of Richmond was sold to a firm who were the first to employ ocean liners for ocean pleasure cruising, and for two or three summers she sailed from Newcastle to the Norwegian fjords.

Upon the death of Mr. William Inman, which occurred in 1881, the management of the line was taken over by Messrs. Richardson, Spence \& Co. Since then it has undergone several changes. Its title of Inman Line was discontinued, and that of "American" Line adopted, and its British headquarters transferred from Liverpool to Southampton. It is now (1903) one of the group of Atlantic steamship companies included in the "Morgan" combine.

In 1863, a number of Liverpool merchants and shipowners, anticipating a large trade would arise between this country and the Confederate States of North America on the termination of the civil war then raging, formed themselves into a company under the title of the National Steam Navigation Co., with a capital of $£ 700,000$. It was the intention of the promoters of the company to establish a regular service of firstclass steamships between Liverpool and the Southern States. The requisite capital was quickly subscribed, and three steamships were promptly acquired; but, alas! the hoped-for peace did not arrive as soon as the promoters anticipated. Under these circumstances the Directors decided to enter into competition with the Cunard and Inman Companies for a share of the passenger and goods trade to and from the Northern States. The pioneer vessel of the new company was the Louisiana, which vessel sailed on her maiden voyage from Liverpool to New York in the year 1863. She was followed by the Virginia and the Pennsyluania, each of these vessels being between 3,000 and 3,500 gross tonnage, and consequently they were the largest cargo carriers afloat at that time. 1) uring the following year (1864) three new steamers of still larger tonnage were added to the fleet. These were named respectively The Queen, Lrin and Helvetia. So successful were these vessels that twelve months later (1865) two more steamers were built for the Company, viz., the ExgLand and 
DENMark, both of 3,723 tons gross, and these were followed in 1866 by the France, a vessel of about the same tonnage.

A great advance in the size of the Company's steamers was made in 1868, when the ItaLY, a steamer of 4,300 tons, was placed on the line. Not only was the Itraly the largest transatlantic liner at that date, but she was also the first in which compound engines were fitted. A somewhat smaller steamship, the Holland, of 3,847 tons gross, was built in 1869 . The following year two very large and powerful vessels were added to the fleet. These were the EGrpt, of 4,669 tons gross, and the SpaIn, of 4,512 tons; both steamers were built on the Mersey, the former by the Liverpool Shipbuilding Co., and the latter by Messrs. Laird, of Birkenhead.

The Company now possessed a sufficiently large fleet to maintain a regular weekly service between Liverpool and New York, sailing from Liverpool every Wednesday, and from New York every Saturday; and a fortnightly service from London to New York, via Havre.

The steamships of this line were good, roomy, comfortable boats, with lofty 'tween decks. They carried immense cargoes of cotton, grain, provisions, and other American produce from the United States to Great Britain, and though they could not compare with the Cunard or Inman liners in the elegance of the accommodation provided for saloon passengers, yet they were well adapted for the conveyance of emigrants, of whom they carried large numbers. As they did not specially cater for saloon passengers, and carried no mails, they were not driven at the high rate of speed maintained by the premier transatlantic steamship companies. It is true that for a time the National Line held the "Blue Ribbon" of the Atlantic, but this honourable position was held for a very short time only, and the ressel by which it was gained was sold to the Italian Government. The steamer referred to was the America, built and engined by Messis. J. \& G. Thomson, Glasgow, in 188:\%. Her gross tonnage was 5,528 tons, with compound engines of 1,064 horse-power nominal. Her length was 441 feet 8 inches; breadth, 51 feet 2 inches; and her depth :36 feet. 
In less than twelve months from the date of her launch, she was purchased by the Italian Government, by whom she was equipped as an armed cruiser, and renamed Italia. Prior to the construction of the America, the Company had increased its fleet by the addition of the steamers Greece and Canada. On the 31st December, 1889, the ERIn sailed with seventy-two persons on board, and disappeared without leaving a trace.

After trading successfully for a number of years, the National Steamship Company got into financial difficulties. Its vessels were dispersed; the Liverpool service to New York was abandoned, and only that from London retained. When the nineteenth century closed the only steamers sailing under its flag were the America, Europe and Manhattan. These three steamers are built of steel, and each carries four masts. They are all driven by triple-expansion engines, and the last-named vessel is a twin-screw steamer. The respective measurements are as follows :-

America, 5,158 tons gross, built and engined by Gourlay Brothers \& Co., Dundee, in 1891, is 435 feet long, 46 feet 3 inches broad, and 25 feet 2 inches deep, with engines of 516 nominal horse-power.

Europe, 5,302 tons gross, built and engined by Palmers, Limited, Newcastle, in 1891, is 435 feet long, 46 feet 4 inches broad, and 25 feet 2 inches deep, with engines of 545 nominal horse-power.

Manilattan, 8,004 tons gross, built and engined by Harland and Wolff, Belfast, in 1898, is 490 feet 5 inches long, 56 feet 3 inches broad, and 25 feet deep, with engines of 478 nominal horse-power.

The National Line, like the Inman Line, has now been absorbed by the American combine.

For several years prior to $1863, \mathrm{Mr}$. Stephen B. Guion, of New York, had established a line of clipper ships between that port and Liverpool. Finding it impossible to contend against screw steamers in the ocean trade, he entered (in the year named) into an arrangement to supply, through his old connections and agents in America, the Cunard and National Companies with steerage passengers and cargo for their steamers. 
This arrangement held good until 1866, when Mr. Guion, in co-partnery with others, formed a steamship company whose official title was "The Liverpool and Great Western Steamship Co.," but which was popularly known as the Guion Line. The first steamer of the new line was the iron screw steamej. Manifattan, which sailed from Liverpool to New York in August, 1866. This steamer was still afloat in 1903, being then the property of Messrs. W. H. Ross \& Co., by whom she was renamed the Citr of Liscolx. The fleet of the Guion Line was speedily sufficiently numerous to maintain a regular weekly service from Liverpool to New York, and within six years of the formation of the Company it possessed eight firstclass iron screw steamships, each of about 3,000 tons burthen. They were named after the Western States of America, viz., Manhattan, Nebraska, Minnesota, Colorado, Inalio, Nevada, Wisconsix, and Wroming. In $18 \pi 4$ the Moxtaxa, of 3,500 tons, was added to the fleet, which was further increased in 187.5 by the addition of the Daкот.

None of the vessels named had distinguished themselves by their extraordinary speed; but in 1879 there was built for the Guion Line, by the Fairfield Shipbuilding Company, the steamer Arizora. She was an entirely new type of vessel. The older ships, though differing in their models, might be described generally as brig rigged screw steamers carrying a single funnel amidships, and having their saloons aft. The Arizoxi carried four masts, of which the fore and main were square rigged, and two funnels between the main and mizzen masts. The saloon was situated amidships, and was superbly furnished. The length of the ARIzoxi was 450 feet, her breadth 45 feet, and her depth 35 feet. She sailed on her first voyage from Liverpool to New York on the 31st May, 1879, and is at the present date (1903) employed as a troopship by the U.S. Government, her name having been changed to the Haxcock.

A sister ressel to the Arizont was built by the same builders in 1881. She was larger and more powerful than the Arizoxi, and increased the reputation for speed which that steamer had created. The AlaskA left Liverpool on her maiden voyage on 
the 29th October, 1881. On the 12th September, 1882, she sailed from New York, and completed her voyage to Queenstown in 6 days 18 hours and 38 minutes. This rapid passage was, however, excelled by the same Company's steamer Oregon, which sailed from Liverpool to New York on the 6th October, 188:3, and made the passage from Queenstown to Sandy Hook in 6 days 10 hours and 9 minutes. The OrEgon was also built and engined by the Fairfield Shipbuilding Co. She was 501 feet long, 54 feet 2 inches broad, and 38 feet deep. Her gross tonnage was 7,375 tons; and her engines developed 13,500 horse-power, giving a speed of 18 knots per hour. Her career was a brief but brilliant one. Built in 1883, she sank after a collision with an American schooner on the 11th March, in 1886 .

These three celebrated steamers, the Alaska, Arizona and OrEgon were popularly known as the "Greyhounds of the Atlantic." As has been stated, the OREgor was lost after collision, the Arizona is still afloat, and the Alaska was sold in 1902 for the purpose of breaking up. After the decease of Mr. S. J3. Guion, which occurred on the 19th December, 1885, the steamers of the fleet were gradually disposed of to various purchasers. 'The firm, however, of Guion \& Co. is still in existence, as passenger agents, the business being carried on by Mr. Frank Ramsden and Mr. I. O. Roberts.

The Royal Atlantic Steam Navigation Company, better known as the "Galway Line," was established by a number of English and Irish gentlemen, who in January, 1859, proposed to the British Government to carry H.M. mails from Galway to Portland, Boston, or New York, via St. John's, Newfoundland, or otherwise, for the sum of $£ 3,000$ on the round voyage. They further offered " to convey telegraphic messages from the United Kingdom to British North America and the United States in six days, casualties excepted." As the Atlantic cable was not then in existence, the Govermment was favourably disposed to the scheme, and on the 21st April, 1859, a contract was entered into with the said company, based on the terms of the proposals made to the Government.

On the 10th. Tune following, the Royal Atlantic Steam Navi- 
gation Company contracted with Messrs. Palmer, of Newcastle, for the construction of two steamships, the cost of each to be $£ 95,000$; and five days later (15th June) they concluded a similar contract with Messrs. Samuelson, of Hull, for two steamships, to cost $£ 97,000$ each. As the date of the commencement of the postal service, according to the Government contract, was fixed for June, 1860, the contract with the builders stipulated for delivery of the vessels within eleven months from the date of the agreement. It was also a condition of the contracts, that the ships were to be built according to lines, plans, and specifications approved by the Admiralty. The four steamships referred to were almost uniform in model, measurement and equipment. Each measured about 2,800 tons, with engines of about 850 nominal horse-power. Their principal dimensions were-Length 360 feet, beam 40 feet, and depth of hold 32 feet. Those built by Messrs. Palmer were named Connaught and Hibernia, and those by Messis. Samuelson, Columbia and Axgria. A clause in the Company's contract with the builders specified "that each of the said vessels when completed was, on a fair and proper trial thereof, to accomplish a speed at the rate of 20 statute miles per hour in smooth water, and to consume not more than 8,800 pounds of fuel per hour." In the case of the Consaught this condition was not complied with, for on her trial trip the Government Inspector reported that the speed of this "vessel was about thirteen knots."

From its commencement the Company was in difficulties. The second steamer, the Hibersia, on being surveyed by the Government Inspectors, was found to be leaky. None of the vessels were delivered within the time agreed upon, and in order to keep faith with the Government the Company was compelled to charter a steamer to inaugurate the service. They accordingly hired from the Messrs. Malcomsons, of Waterford, one of their Liverpool and River Plate steamers, the Parana, which sailed from Galway on the 2⿰th June, 1860, and arrived at St. John's in seven days thirteen and a half hours, or one day thirteen and a half hours beyond the stipulated time for delivering the telegraph messages at St. John's. 
The second steamer to sail from Galway was the Consalght, which sailed for Boston direct on the 11th July, and was twenty-two and a half hours over contract time in arriving at that port. This steamer was totally lost on her second voyage in Uctober of the same year.

The third steamer of the Company sailed from Galway on the 9th April, 1861, and returned in May following in a disabled condition, having met with ice on the passage. She made the slowest passage outwards of any of the fleet, having taken ten days seven and a half hours to reach St. John's, and seventeen days twenty and three quarter hours to reach Boston.

As two of their own steamers were unavailable, the one being lost and the other disabled, the Directors found it necessary to take up outside steamers. They therefore chartered the Prince Albert, and purchased the Adriatic, one of the latest and most famous of the Collins Line. She appears to have been the only vessel belonging to the Company capable of carrying out the terms of the Government Contract. She completed the run from Galway to St. John's in the specified time, six days, and to New York in one day fifteen hours and fifteen minutes less than contract time. On her return she made the passage from St. John's to Galway in five days nineteen hours and three quarters, the shortest passage on record from port to port across the Atlantic. It is impossible to state what would have been the result had the steamers built for the Company been equal to the Anriatic, but she was secured too late to retrieve the fortunes of the Company. Unable under such adverse circumstances to raise fresh capital, the managers of the Company had no course left but to abandon their undertaking, and they terminated their contract in May, 1861. This unfortunate enterprise entailed a loss to the Government of about $£ 15,000$, while it is probable that the loss incurred by the shareholders of the Company was not less than $£ 150,000$ during the short period of its existence. 


\section{Chapter xViII.}

The Orion wrecked off Portpatrick, 1850.--The steamer Neptunk.A second "Grace Darling," 1852.

(ONE of the most convincing proofs of the splendid management of the several steamship companies which trade between Liverpool and Glasgow, of the skill and honest workmanship put into the vessels, and of the great care exercised by the officers who navigate these ships, is the fact that for upwards of eighty years there has been but one disaster accompanied by loss of life on this station.

The disaster referred to was described at the time as "a disaster occasioned by the most culpable carelessness." It was, unfortunately, attended with frightful loss of life. The Orion, a splendidly fitted and powerful steamer, sailed from Liverpool for Glasgow, on Monday afternoon, 18th June, 1850, with about 16 passengers in addition to a crew of 40 all told. It was an ideal summer trip; the night was fine and clear, and the sea perfectly smooth. All went well with the steamer and those on board until, about a quarter past one on the Tuesday morning, the sleeping passengers were rudely awakened by the concussion, as the ship struck violently on the rocks, close to the Lighthouse at the entrance to Portpatrick Harbour. The vessel, which was steaming at full speed at the time, filled instantly, and sank in a few minutes. The night was so tranquil that many of the passengers had slept on deck, but the majority were asleep in the cabins below when the catastrophe occurred. The scene of horror and dismay which followed can be but faintly conceived. A wild rush of erew and passengers was made to the boats. The first boat lowered to the water was so crowded instantly with panicstricken passengers, that she capsized, and all who were in her 
were drowned. A second boat was launched, in which some ladies were placed, and these reached the harbour safely. One redeeming feature in this tragic narrative is the splendid heroism displayed by many of the gentlemen passengers. The second boat when launched was in the first instance filled by men, but when the officers of the ship suggested to them that their first duty was to save the women and children, most of the men instantly left the boat, and assisted females to occupy the places they had surrendered, who were thus happily preserved.

Shortly after this boat got away the ill-fated ORION sank, and all on board either went down with her, or were left floating on the surface of the water, or clinging to floating portions of the wreck.

The Ardrossan and Fleetwood steamship Fenerca passed the scene immediately after the disaster occurred, and the Captain at once stopped his ship, lowered his boats, and rendered valuable assistance in saving lives. The Lighthouse keepers and Coastguards had also observed the vessel coming too close in shore, and, anticipating a catastrophe, had awakened the local boatmen. Owing to this, numerous boats had instantly put off, and these picked up a large number of those floating. 3y the continued efforts of the Fenelua's crew, and the Portpatrick boatmein, about 150 persons were rescued. This dreadful catastrophe carried mourning into many of the most respectable families in Liverpool and Glasgow. Amongst those who perished were Captain McNeil (brother of the Lord Advocate), his wife and two daughters; Dr. Burns, one of the most popular men in Glasgow, professor of Surgery at the University, and brother to the Managing owners in Glasgow ; Miss Morris, his niece; and Master Martin, a son of one of the Liverpool owners. The trial of the Captain, and first and second mates of the ORION, for the "culpable bereavement of the live's of the passengers" who were lost by the wreck of that steamer, as before narrated, took place at Edinburgh, before the High Court of Justice, on the 29th August, 1850. It was proved that during the second mate's watch, the vessel approached closer to the shore more than was usual by upwards 
of a mile, and that this course was maintained notwithstanding the warning exclamations of the experienced seamen who were on the look out.

It was further proved that the Captain had come on deck several times during the second mate's watch, and each time had observed both the compass, and the ship's proximity to the shore, which could be clearly seen, and yet did not countermand the second mate's instructions.

The charge against the first mate was withdrawn, but at the end of the trial, which lasted two days, the Court sentenced the Captain to be imprisoned for eighteen months, and the second mate to be transported for seven years.

It is a relief to turn from this sad story to an incident connected with the steamer Neptune, ${ }^{*}$ of which the heroine was a young Norwegian girl, who has been appropriately termed "A second Grace Darling." During the 25th, 26th and 2 $\tau_{\text {th }}$ November, 1852, a strong gale prevailed in the North Sea. About midnight on the last date the Neprune arrived off the Lighthouse at the entrance to Flekke Fjord, Norway. She was bound from London to St. Petersburg, and had the pilot flag flying at her masthead. Just at daybreak the steamer was observed by a young girl, who immediately called up two of the boatmen, who, however, were not apparently inclined to respond to the call.

The girl, however, realizing the urgency of the appeal for a pilot, reproached the men with being afraid of the weather, and under the pressure of her taunts they got their boat out to go to the assistance of the NEPTUNE, the girl accompanying them. When they got near the ship they found that, owing to the heavy surge, it was impossible to get close to the ship's side. A rope was thrown to them, and caught by the girl, who twisted it round her waist and arm, then jumped into the sea and was hauled on board the steamer; the two men thereupon followed her example. This help was most welcome, and the Captain was the more pleased to receive it owing to his cargo having shifted. With the assistance of the Norwegians the rest of

* For further particulars respecting this steamer, see the History of the Waterford Steamship Co. in Part II. 
the voyage was safely accomplished. There were eight lady passengers on board the Neptuxe, who made much of the Norse “Grace Darling," provided her with dry clothing, and gave her a handsome donation in cash. The seamen and firemen also contributed three pounds $(£ 3)$ for the same purpose, and on the return voyage she was put ashore at the place where she embarked, most fortunately with a considerable amount of cash in her possession, as her master refused to permit her to return to his service.

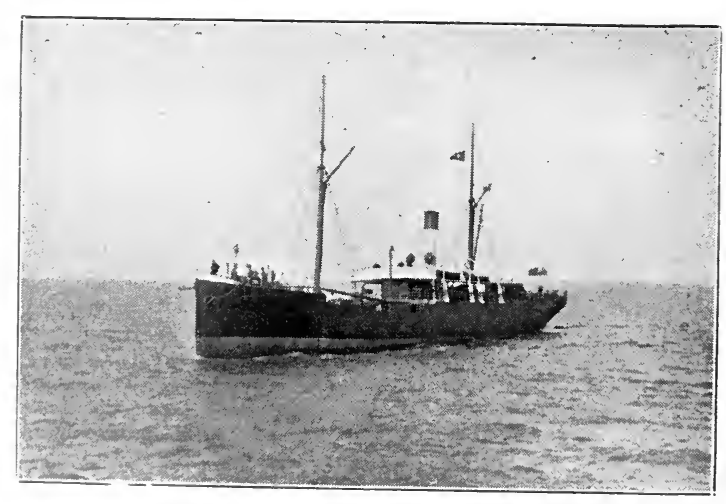




\section{Chapter Xix.}

The Eastern Steam Navigation Co., Ltd., and the Great EAstern, steamship.

Is the year 1851 a steamship company was promoted in London, under the title of the Eastern Steam Navigation Company, Limited, for the purpose of establishing a direct line of leviathan steamers between England and India, via the Cape of Good Hope.

The services of the most distinguished engineers of the period were secured, Mr. J. K. Brunel being appointed the consulting engineer of the company. An order was placed with Messrs. Scott Russell \& Co. for the pioneer steamer, which it was at first the intention of the company to call the Leviatian, but that name was subsequently abandoned in favour of Great Easters. She was to be propelled by paddle wheels and a propeller. Mr. Scott Russell designed the lines, and constructed the hull of the vessel, as well as the engines of 1,000 h.p. nom. to drive the paddle wheels. Messrs. James Watt \& Co., of Soho, designed and constructed the engines, of 1,500 h. p. nom., to drive the screw propeller. As a matter of course, some considerable time was occupied in preparing the plans for so gigantic a ship-one which was not only the largest ever built up to that date, but which remained the largest steamer built to the end of the 19th century. The necessary plans, specifications and yard preparations were completed during the spring of 1854 , and on the 1st of May of that year, the construction of the Great Fastrix was commenced by Mr. Scott Russell in his shipbuilding yard at Millwall, on the north side of the Thames. She was built with a double hull from the keel to the water line, the inner and the outer skin being of equal thickness of iron, with a 


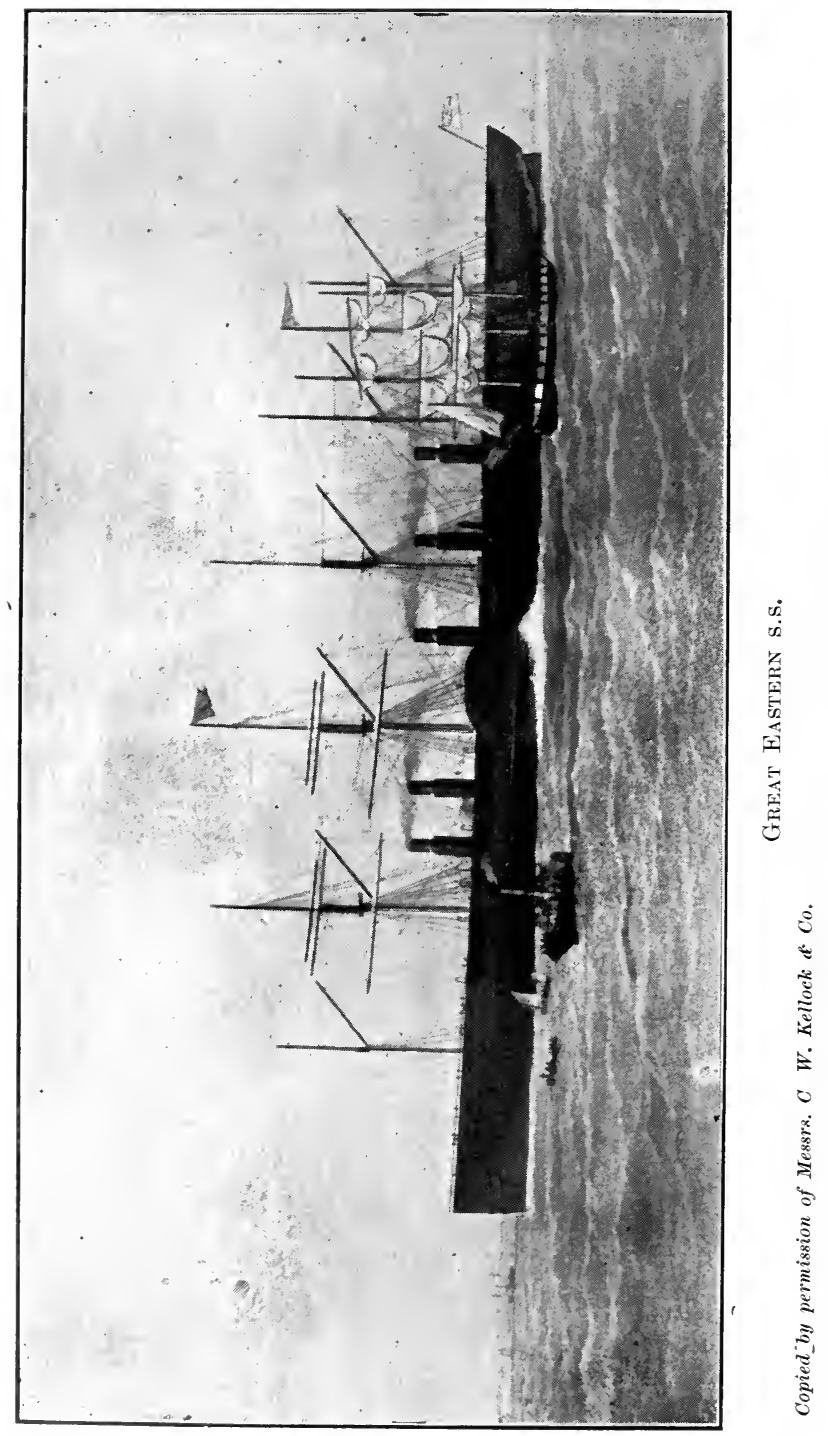


space between of 34 inches. If required for ballasting purposes, this space could be filled with 2,500 tons of water. The length of the GrEat EAsters was 675 feet, her breadth 83 feet, and her depth 60 feet. She was divided into 60 watertight compartments, each 60 feet long. She carried six masts - the mizzen mast of wood, and the remaining five of hollow wrought iron. Three of these masts carried square sails, the other three were fore and aft rigged. She had five funnels, two of which were placed forward of the paddle boxes and three aft. Her hull was constructed of 30,000 plates of iron, weighing 10,000 tons, and joined together by $3,000,000$ rivets. "Her cylinders, the four largest in the world . . ( each) 18 feet long, 6 feet in diameter, and 28 tons weight, were successfully cast at the Engineering Works of Messrs. Scott Russell \& Co., Millwall." *

In her equipment were included twenty large lifeboats, and it was intended that she should carry in addition two small steamers, each 100 feet long, to be used for landing and embarking passengers or luggage.

She was designed to carry 10,000 troops or 4,000 passengers, viz., 800 first-class, 2,000 second-class, and 800 third-class, in addition to a crew of about 400, and she was capable of stowing 12,000 tons of coal.

Although, nominally, the engines which drove the paddle wheels were of $1,000 \mathrm{~h}$. p., they were capable of working up to 5,000 h.p., while the screw engines worked up to 6,000 h. p., or with combined paddle and screw her engines could develop 11,000 h. p., which it was estimated would enable her to maintain at sea a speed of 20 knots per hour, and to accomplish the voyage between England and Australia in 30 days.

"It is a question of much interest to determine what " amount of speed this power will impart to the vessel. “Messrs. James Watt \& Co.'s anticipation is that the "speed of the vessel will be about seventeen miles per " hour, and from that to eighteen miles seems to be about

" the limit engineers have hitherto predicted. But we "believe that these anticipations fall very short of what 
" the real speed will be, and which we do not hesitate to "predict, will turn out to be between twenty-four and "twenty-five miles per hour." ("Illustrated London News," 23rd May, 1857).

On Tuesday, 3rd November, 185\%, the first attempt was made to launch the Great Eastern. The hour named for commencing the launching operations was 11 o'clock, and was kept fairly punctually. The chief machinery for moving the hull was boxed off, and nearly altogether out of sight. The vessel's name, Leviathan, was given by Miss Hope (who afterwards became the Duchess of Newcastle), the daughter of the Chairman of the Great Eastern Steam Navigation Company, and the name displayed upon a board; the change of name from Great Eastern to Leviathan occasioning a good deal of surprise. After the customary bottle of wine was smashed against the vessel's bow, a "fortissimo obligato" of sledge hammers resounded above and around - then ceased. The great ship moved for a few feet, then stopped. The congregated thousands waited in suspense, when suddenly a terrific report was heard. One of the powerful drums used in the launch had cracked. An order had been misunderstood; the after-winch handles were turned the wrong way; the heavy iron handles revolved wildly, striking down the men, fracturing their arms and legs, and with a fatal result in one instance.

A second attempt was made to launch the Leviathax on Thursday, 19th November, 1857, but the efforts were even less successful than on the first occcasion, for despite all the mechanical power brought to bear on her she would not move an inch.

On Monday, 11th January, 1858, launching operations were resumed at Millwall, and the monster ship was moved riverwards to the extent of 20 feet. On Tuesday a further advance was made until a little after 3 o'clock in the afternoon, when, having moved 16 feet 10 inches aft, and 15 feet 1 inch forward, it was thought desirable to suspend operations. At high water on the latter day the ship was water borne to the height of $\tau \frac{1}{2}$ feet, which had the effect of diminishing the 
resistance to the extent of 4,000 tons. 'The yard and river' banks were crowded with spectators on the following day (Wednesday), in the expectation that the ship would float, but she was only moved another $2 \frac{1}{2}$ inches. On Thursday the Leviathan was pushed down the full extent of the ways, and there left for the next spring tides.

The completion of the launch of this stupendous and beautiful vessel took place on Sunday, 31st .January, 1858, under the most favourable circumstances, and unattended with a single accident, the high tide lifting the vessel clear off the ways.

It is incomprehensible how so eminent an engineer as Brunel should have made such a mistake as to attempt to force so huge a fabric broadside on into the river. The costly experiment added $£ 120,000$ to the cost of the ship, and practically ruined the company.

From the commencement of the company's operations, the directors were hampered by the failure of many of the shareholders to meet the ealls upon their shares when due. To add to these difficulties, Messrs. Scott Russell \& Co. (the builders of the ship), in 1855, found themselves unable to meet their obligations, and to complete the construction of the Great Eastern.

At the half-yearly meeting of the company, held on the 15th February, 1856, the chairman reported that the failure of Mr. Scott Russell would be a cause of some delay, and of some increased cost in the completion of their vessel, which would be undertaken by the company's engineer, Mr. J. K. Brunel. Twelve months later it was announced that calls to date amounted to $£ 606,000$, of which nearly $£ 200,000$ remained unpaid, owing to a number of other shareholders, in addition to Mr. Scott Russell, having become insolvent.

The opening months of 1858 saw the Great Eastern successfully launched, but the Great Eastern Steam Navigation Company had not the funds necessary for her equipment. During the year the company was wound up by the sale and transfer of the ship to a new company for the sum of $£ 160,000$ 
"All the capital had been expended, the public refused " to advance any more money, and if the directors wished " their ship to be anything but a helpless, unfinished “ carcase on the waters $£ 300,000$ more must be found to "make her ready for sea. To the exertions of Mr. "Campbell (the present chairman of the Board), and to "Mr. William Jackson (the eminent and well-known " contractor of Birkenhead), we believe is greatly owing " the pleasant result of our being at length able to "announce that the Great Eastern is ready for sea. "But one still more remarkable aid was forthcoming, and " which we could hardly believe, only that we have it on " the best authority-it was a subscription of no less than “ $£ 50,000$ of the supplementary capital, in sums of $£ 1$ to “ $£ 5$, by persons in the humblest ranks of life (domestic "servants, costermongers, greengrocers and labourers)"who tendered their money avowedly without any " expectation of profit, but solely that they might hear of " the great ship, which they looked upon as the pride of " England, being fairly afloat on the deep waters. Such "a fact at once took the vessel out of the category of mere " commercial undertakings, and more than anything else "stimulated the brave men who were her projectors to "renewed exertions for her ultimate completion." ("Illustrated London News," 13th August, 1859).

The sum of $£ 300,000$ having been subscribed for the new undertaking, the directors had, after paying for the vessel, a surplus of $£ 140,000$ to complete her equipment and make her ready for sea. Her new owners took possession of her early in 1859 , but it was not until September of that year that she was sufficiently complete to make her first trial trip. While on this trip, and when off Hastings, a shocking accident occurred, through the explosion of one of the funnel casings, causing the death of six men, injuring several others, and virtually wrecking the grand saloon. As no further damage was done to the hull or machinery, she proceeded to Portland, and the necessary repairs having been completed at an outlay of $£ 5,000$, she resumed her voyage to Holyhead on the 8th 
October. She starterl on her return trial trip from Holyhead to Southampton on the 2nd November, 1859, where she remained until the 17 th June, 1860.

The Great EASTERN was advertised to leave siouthampton on her first voyage to New York on Saturday, 16th June, 1860 , but, in consequence of bad weather on that date, the sailing was postponed until the following morning. She carried only 36 passengers, including several ladies, on this trip. The voyage across the Atlantic occupied eleven days. The greatest speed attained was $14 \frac{1}{2}$ knots per hour, and the greatest distance run by her in any one day was 333 miles. Immense crowds assembled to witness her arrival in New York Harbour, and she was welcomed with great enthusiasm. She passed the battery at 4-30 p.m. on the 28th .June, 1860.

The promoters of the Great Eastern Steam Navigation Company were very sanguine that the Government would frequently employ their vessel for the conveyance of troops, of which they estimated she could carry ten thousand. The Government very wisely never risked so great a body of men in one vessel.

The only occasion on which the Great EASTERN was made use of as a troopship was during the threatened rupture between England and the Federal Government of America, in connection with the "Trent Affair." She made her first entry into the port of Liverpool on the 4th June, having made the passage from New York in 9 days 11 hours. She had on board 212 passengers and a large cargo. On Thursday, 27th June, 1861, she sailed out of the Mersey on a voyage to Quebec, with troops to reinforce the Canadian garrisons. The day was cloudless, there was brilliant sunshine, and the piers and dock walls for five miles, as well as the landing-stages, were lined with spectators, who, as the great ship passed them, responded most heartily to the cheers raised by the soldiers who thronged the upper deck and the lower portions of the rigging.

As she passed the landing-stages she fired salutes, and also on passing the Rock Battery. There were on board the Great Eastern, not 10,000 troops as her promoters 
anticipated, but 2,125 men of all ranks, accompanied by 159 wives and 244 children of the soldiers. There were also about 40 eivilian passengers in the saloon.

She left Quebec on her return voyage on the 6th August, arriving in Liverpool on the 15th idem, and resumed her sailings to New York.

She sailed from Liverpool for New York on the 10th September, under the command of Captain Walker, having on board 175 cabin and 193 steerage passengers. On the following Thursday she encountered a heavy gale, during which, when about 280 miles westward of Cape Clear, her steering apparatus became deranged and broken, and five of her lifeboats were carried away. For two days and nights she lay helpless, exposed to a terrific sea. Her internal fittings were in consequence seriously damaged, and her passengers greatly alarmed for their safety. The Captain decided to abandon the voyage and put back to Queenstown, arriving in the harbour on the Tuesday following. The passengers, when once more on terra firma, relieved their feelings by publishing some very angry letters in the Press, in which they reflected very severely on the managers of the company, but gave unqualified praise to Captain Walker for the manner in which he had handled the great ship in her disabled state.

The laying of submarine cables, commenced in 1865, offered employment for which the Great Eastern was specially suitable, and in which she was constantly engaged for a period of ten years.

Shortly after noon on the 30th June, 1866, the Great Easters left the Medway, having on board the second Atlantic cable. She was convoyed by H.M.S. ADDEr as far as the Nore. As she steamed past Garrison Point she was loudly cheered by a vast concourse of people who had gathered there. She proceeded direct to Berehaven, in the extreme SouthWest of Ireland, which was to be her starting point for laying the submarine cable. Four weeks later, or to be exact, ab'ut 5 o'elock (English time) on the 27th July, this great task was successfully accomplished. One of the earliest messages transmitted by the cable was the following from H.M. 
Queen Victoria to the President of the United States of America:-

"The Queen congratulates the President on the "successful completion of an undertaking which she

"hopes may serve as an additional bond of union between "the United States and England."

President Johnson suitably acknowledged the Royal despatch, and reciprocated the good wishes contained in it. [A most interesting diary of the Atlantic Telegraph Expedition is published in the Annual Register for 1866.]

In 1867 her cable-laying services were interrupted by a charter to a French company, who employed her between Brest and New York, carrying passengers to and from the great French Exhibition. For this service she was fitted with new boilers for the screw engines, and her saloons were altered and redecorated.

After the completion of her charter with the French company, she was taken up by the Telegraphic Construction and Maintenance Company, in whose service she remained for seven years. During this period she succeeded in laying the cable between Brest and Duckburgh, near Boston, Mass., in 1868; between Aden and Bombay in 1870; between Valentia and Heart's Content, in 1873 and 18r4; completing her charter to the Telegraphic Construction Company in July, 18r5. The amount received for charter was at the rate of $£ 20,000$ per annum, nett form.

The last years of this noble vessel were ignominious. She was chartered in 1896 by "Lewis's," who used her for a couple of years as a huge floating advertisement on the Mersey. She afterwards went to several Ports as a "show" ship, and finally returned to the Mersey to be broken up on the 20th November, 1888. Her owners at this time were probably the only persons who ever realized a handsome profit out of her during her varied career. The following is a list of the prices obtained at the sale of the various parts of the hull and equipment:-

Eleven-ton 'Trotman's anchor, 3:3 guineas, in addition to a number of other anchors, which realized $£ 3$ to $£ 7$ 15s. per 
ton; oak lifeboat, 2 guineas; cutter, 30 s.; iron masts, $£ 9$ to $£ 1$ \% 10 s. each; copper steam piping, $£ 2,960$; gun metal, $£ 6,400$; scrap yellow brass, $£ 1,760$; sheet lead, $£ 36710$ s.; lead piping, $£ 36710$ s.; iron plates forming the hull, $£ 12,600$; iron beams, £2 13s. per ton; scrap rivets, £2 6s. per ton; boiler tubes, $£ 49$ is. 6 d. *

So ended the career of the most celebrated ship of the 19th century.

*The above figures are obtained from "Donaldson's Engineers' Annual," 1900 , by permission. 


\section{Chapter XX.}

Steam to Australia.-SopHIA JANE, first steamer from Great Britain to Australia, 1831.- The steamship Great Britain sails for Melbourne, 1852.Sketch of her after career.-The GoLDEN AGE.-The auxiliary screw steamer Royal Charter.--Sails on her maiden voyage, 1856.-Totally lost, 1859.

THE first voyage by a steamer ever made between Great Britain and Australia was in 1831 by the Sophin JANE, a small vessel of 256 tons burthen and 50 h.p. (see reference to this vessel in the History of the Cork Steamship Co., Limited).

Twenty-one years later the owners of the Graat Britain, the Liverpool and Australian Steam Navigation Co. (Messrs. Gibbs, Bright \& Co., Managers), induced by the great rush of emigrants to the newly discovered Australian goldfields, decided to supplement their "Eagle" Line of Packets by the addition of screw steamers and issued an advertisement as follows :-

"Steam from Liverpool to Australia, forming part of the “ 'Eagle' Line of Packets.

"The Great Britain, S.S., 3,500 tons and 500 h.p., B. "R. Matthews, R.N., Commander, will be despatched for "Melbourne and Sydney, N.S.W., calling at the Cape " of Good Hope for coals, water and fresh provisions, on "Saturday, 21st August, 1852, at 1 p.m. This mag" nificent ship, fitted up with every possible convenience, " has just performed her trial voyage to New York in the " most satisfactory manner.

"Fares:-After Saloon, to Melbourne, 70 guineas and “upwards. Five guineas extra to Sydney, N.S.W.

"To Cape of Good Hope, 50 guineas.

" Loading Berth, Wellington Dock.

"Apply to Gibbs, Bright \& Co., Liverpool."

The result must have been exceedingly gratifying to the owners, as the GraAt Britain sailed on this her first royage to the Antipodes with upwards of 600 passengers. Ten days 
later the ship Albatross arrived with the first importation into Liverpool of gold from Australia, being 20,000 ozs. consigned to Messrs. Gibbs, Bright \& Co. On the 2:3rd November following, her sister ship, the EAgLe, arrived in the Thames with 150,000 ounces of gold valued at $£ 600,000$. The ship DIDo was expected to arrive in a few days, having on board ten and a half tons of the precious metal, of the enormous value of $£ 1,120,000$.

The Griat Britain arrived at Melbourne on the 10th November, 1852, after a splendid run from the Cape of Good Hope of 24 days, her average speed having been 284 miles per day. Her engines behaved splendidly, and there was no occasion to stop them during the whole of the time. One death occurred on board, that of a Chinaman who embarked at St. Helena.

Owing to the difficulty of obtaining labour to discharge and load the ship at Melbourne, she was detained at that port for three months, and sailed on her return voyage about the end of January, 1853. On her arrival at Cape Town she re-filled her bunkers from the REBEccA, a ship which had been sent from Liverpool with a cargo of coal for that purpose, and resumed her voyage northwards on the 20th February.

She continued to trade with varying success between Liverpool and Australia as an auxiliary steamer for 40 years, and in 1882 was sold to Messrs. Anthony Gibbs, Sons \& Co., who took out her engines and converted her into a sailing ship. Originally she carried six masts, two of which had been taken out of her when she was placed on the Anglo-Australian station, and when Messrs. Anthony Gibbs, Sons \& Co. purchased her they took out a third mast and rigged her as a full-rigged sailing ship. In order to strengthen her hull, they also, at a very great expense, completely sheathed her frame with wood, in October, 1882. She sailed on her last voyage from Liverpool in 1886, and put into the Falkland Islands so battered with her battle with wind and waves that she was abandoned to the Underwriters as a constructive total loss. She was sold by the latter to the Falkland Islands Co., who used her as a coal hulk. 
One of her earliest competitors was an American steamer named the Goldex Age. She was the property of the New York and Australian Steam Navigation Co., and was intended to ply between Australia and Panama, and eventually to extend the service to San Francisco. This splendid vessel excited great interest in Liverpool, at which port she lay for about two months prior to sailing for Melbourne.

She was very similar in outward appearance to the Collins steamships, being barque rigged with a straight stem, and having her paddle boxes situated very far aft. Her dimensions were as follows: length 285 feet, beam 43 feet 6 inches, and depth 32 feet; 2864 tons register. She had a beam engine of somewhat peculiar construction, with a cylinder of 85 inches diameter, and 12 feet stroke. The boilers constituted the chief peculiarity; they were each 40 feet long, and fitted with furnaces at each end, the smoke funnel ascending from the centre. By this arrangement it was elaimed that economy both in space and fuel was gained. The hull of the ship was built by Mr. W. H. Brown, New York. The lower frames were of live oak, and the top frames of locust and cedar. The entire hull was double diagonally braced with iron bars, five inches wide, by three quarters of an inch thick and four feet apart.

The Golden Age had accommodation for 1200 passengers of all classes, the steerage being fitted up for 600 . There were three saloons, one above the other, two of which were panelled in rose, satin, and zebra woods; with erimson and gold plush and rich hangings, and adorned with mirrors. In the upper saloon the same general arrangement prevailed, except that instead of satinwood panelling, the sides were finished in white and gold. In this saloon were two "family rooms," one finished in gold, the other in blue. A brief reference to this steamer is made in the "Annals of Liverpool" (Gore's Directory), in which it is stated: "The GoLder AGE.(s.) sailed from Liverpool, 5th December, 1853, and arrived at Melbourne in $4 \pi$ days steaming time."

On the 31st .July, 1855, there was launched at Sandyeroft, on the River Dée, a large elipper ship fitted with auxiliary 
steam power. She was built to the order of the Liverpool and Australian Steam Navigation Co., the owners of the celebrated Great Britain. Her owners were of opinion that steamers relying entirely upon their engines, could not be worked so economically as vessels with auxiliary steam power, and sailing vessels trusting only to their sails could not be relied upon to make their passages with regularity and despatch, consequently they determined to combine the two motive powers and give their vessel the benefit of both.

The Royal Charter, the name given to the new ship, was designed and built by Mr. Paterson, the builder of the Great Britaix. She was 235 feet in length over all, 41 feet 6 inches beam, and 26 feet 6 inches depth of hold; 2720 tons burden; could spread 15,000 square feet of canvas; and had a pair of direct acting trunk engines of 200 h.p. nominal, constructed by Messrs. Penn, of Greenwich, for working an auxiliary screw, so arranged that when not wanted it could be completely lifted out of the water, and even (if necessary) placed on deck. She had excellent accommodation for passengers. Her chief saloon was 100 feet long and beautifully fitted up; and the ladies' cabin, with its large poop windows, and elegant furniture, was admirably adapted for its purpose. There were two large bath rooms for the use of the after saloon passengers, and one three times as large as either of these two for the use of the 'tween deck passengers. She had seven watertight compartments and tanks capable of holding 64,000 gallons of water.

The Royal Charter, independently of her steam power, was a full-rigged ship, and was the first English vessel to adopt the American plan of double topsails on each mast. On her trial trips she averaged a speed of nine knots per hour with her propeller; and under canvas only, with a light N.X.E. wind, made fourteen knots per hour.

she was well armed, carrying eight guns-four 18 pounders and four 24 pounders; besides a large swivel gun on the forecastle, and a good number of Minié rifles for the saloon.

She left Liverpool on her maiden voyage to Melbourne on the 16th April, 1856, and accomplished the passage in 59 days. the had but a short career, for on the 26th October, 1859, this 
noble ship was totally wrecked on the coast of Anglesea. She had almost reached her home port, inward bound from Australia under the command of Captain Taylor, and having on board about 500 persons including passengers and crew, and a valuable cargo, including gold to the amount of $£ 400,000$. She had called at Queenstown, where thirteen of her passengers disembarked. On her passage up channel she was caught in a terrific northerly gale, which, driving the current in the large bay between the Ormes Head and Point Lynas, swept the vessel from her course and drove her upon the rock-bound coast off Moelfra Head, Red Wharf Bay. She struck during the night when no assistance from the shore could be obtained. From 30 to 35 persons only were saved out of the 500 on board, and these mainly through the heroic efforts of Joseph Rodgers, who swam ashore with a line round his body. In recognition of his devoted courage, this intrepid seaman was presented with a gold medal and $£ 5$ by the Royal National Lifeboat Institution at a meeting held at the Sailors' Home, Liverpool, on the 16th November, 1859, on which occasion the Board of Trade also presented him with a silver medal and $£ 10$.

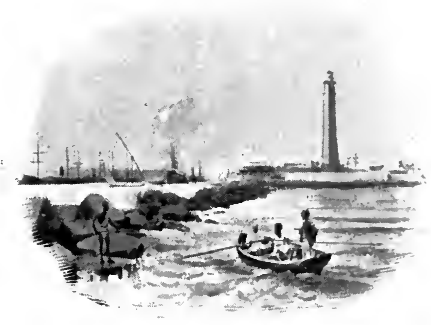




\section{Chapter XXI.}

China and Steam Navigation.-Opening of the Treaty Ports, 1860.Auxiliary Steamers first employed.-The Scotland.-The Robert Bruce.The Holt Line.

The treaty ports of the Yang-tse were for the first time opened to the ships of the "barbarian nations of the West" in February, 1860.

The first foreign merchant vessel to load a cargo at Shanghai for Hankow was the auxiliary screw steamer Scotland, belonging to the late W. S. Lindsay, the wellknown author of the "History of Merchant Shipping." She was a vessel of about 1,100 tons gross register, and was commanded by Captain A. D. Dundas, R.N. She sailed from Shanghai with a full cargo in June, 1860, her draft being 17 feet. She was subsequently sold to the Prince of Satsuma, the same purchaser having previously, in 1861, purchased her sister ship, the England, from Messrs. W. S. Lindsay \& Co.

It was not until 1863 that any English steamer loaded a cargo direct from Hankow for Great Britain. The third vessel to sail was the auxiliary screw steamship RoBERT Lowe, also belonging to Messrs. Lindsay. She was a vessel of 1,250 tons gross, with engines of only 80 nominal horse power. Her average speed between Shanghai and Hankow, a distance of 608 miles, was 60 miles per day, but one day was lost in changing her propeller, and she anchored every night. She sailed from Shanghai on the 8th May, 1863, and came to an anchor off Hankow on the 18th idem. On the 10th June her cargo arrived alongside, and on the 23rd June she sailed for Shanghai and London. She traversed the distance between Hankow and Shanghai in 57 hours, the current being with her. Her cargo for London consisted of 9,568 chests, 234 half-chests, and 2,064 boxes of tea; 535 bales of cotton and 192 packages of sundries. Her freight amounted to the respectable sum of $£ 10,315$, in addition to which she earned $£ 480$ passage money.

In $1866 \mathrm{Mr}_{\mathrm{Mr}}$. Alfred Holt, of Liverpool, started a line of steamers to trade between England and China, via the Cape 
of Good Hope. Mr. Holt was a practical engineer. Having served his apprenticeship, he was appointed inspecting engineer to several steamship companies, and about $1850 \mathrm{com}-$ menced as steamship owner with a small coasting steamer, the Alpina. This steamer was succeeded by the Crafator and Dumbarton Youth, sailing between Liverpool, Cumberland Ports, and the Bristol Channel.

Upon the outbreak of the Crimean War, Mr. Holt secured several remunerative charters from the Government, and in 1855 he inaugurated the first line of steamers between Liverpool and the West Indies. His first steamer in this trade was only 535 tons burden, but she was so well supported that in a short time a monthly line of steamers of larger capacity and greater power was established.

In 1863 Messrs. Leech, Harrison and Forwood, and Messrs. Imrie and Tomlinson, entered into the same trade, and it was considered desirable to form a public company to amalgamate these three undertakings. A company, under the title of the West India and Pacific Steam Navigation Company, Limited, was consequently formed for this purpose, with a capital of $£ 1,250,000$, which was at once subscribed.

Mr. Holt now directed his energies to the Far Last, and in 1865 despatched his first vessels in the China service, the Agamemnox, Ajax and Achilles. These were the first steamers to apply the principle of compound engines to long over-sea voyages. These engines were in use in the ships of the Pacific Steam Navigation Company prior to this, but only in those steamers employed on the Pacific coast. The performances of the Holt steamers had been hitherto considered impossible, and even now in the twentieth century would be considered remarkable with boats of a similar size. Starting from Liverpool, they steamed down the South Atlantic, rounded the Cape of Good Hope, and so on to Mauritius, a distance of 8,500 miles without stopping. From thence they proceeded to Penang, Singapore, Hong Kong and Shanghai.

These three pioneers of the Anglo-China trade were each of 2,270 tons gross and 1,550 tons net register, with engines of 300 nominal horse power, and their principal dimensions 
were--length, 309 feet; beam, $38 \frac{1}{2}$ feet; depth of hold to spar

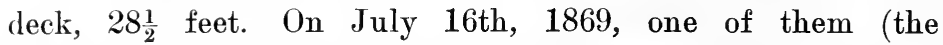
Acnilles) sailed from Foochow for London via the Cape of Good Hope, and arrived on the 16th September, having been under steam 58 days 9 hours, during which time she travelled 13,552 miles, maintaining an average speed of nearly $9 \frac{3}{4}$ knots throughout the whole voyage. This was one of the last voyages made by the Holt steamers round the Cape, as two months after the arrival of the Achilles at London the Suez Canal was formally opened for the merchant steamers of all countries, and from that date all the steamers of this company have passed through that waterway on their voyages to and from China.

The earlier steamers of the fleet were square-rigged on the fore and main masts, a good rig when it was desired to take advantage of the favourable trade winds and monsoons, which can always be depended upon for a voyage round the Cape, but found to be unsuitable when the route was altered to the Suez Canal. The square sails of the three steamers named were, therefore, removed, and the subsequent steamers have been constructed with pole masts only.

Although the fleet is styled the Ocean Steamship Company, it is popularly known as the Holt, or " Blue Funnel " Line, and has only recently been formed into a limited company.

The Holt Line steamers do not carry passengers between Great Britain and China, but they are great favourites with the Moslem pilgrims, of whom they carry large numbers on their journeys to and from Mecca.

About 1891 the Ocean Steamship Company established a monthly service of mail and passenger steamers between Singapore and West Australian Ports, and in 1901 a direct service of steamers from Glasgow to Australian Ports was opened by the despatch of the steamer Orestes.

A controlling interest in the China Mutual Steam Navigation Company, Limited, was purchased by, and the fleet of that company transferred to, the Holt Company on the 1st July, 1902, with which addition to the "Blue Funnel" fleet extended operations were undertaken. 




\section{Chapter XXII.}

\section{REMARKABLE HISTORY OF A GLASGOW STEAMER.}

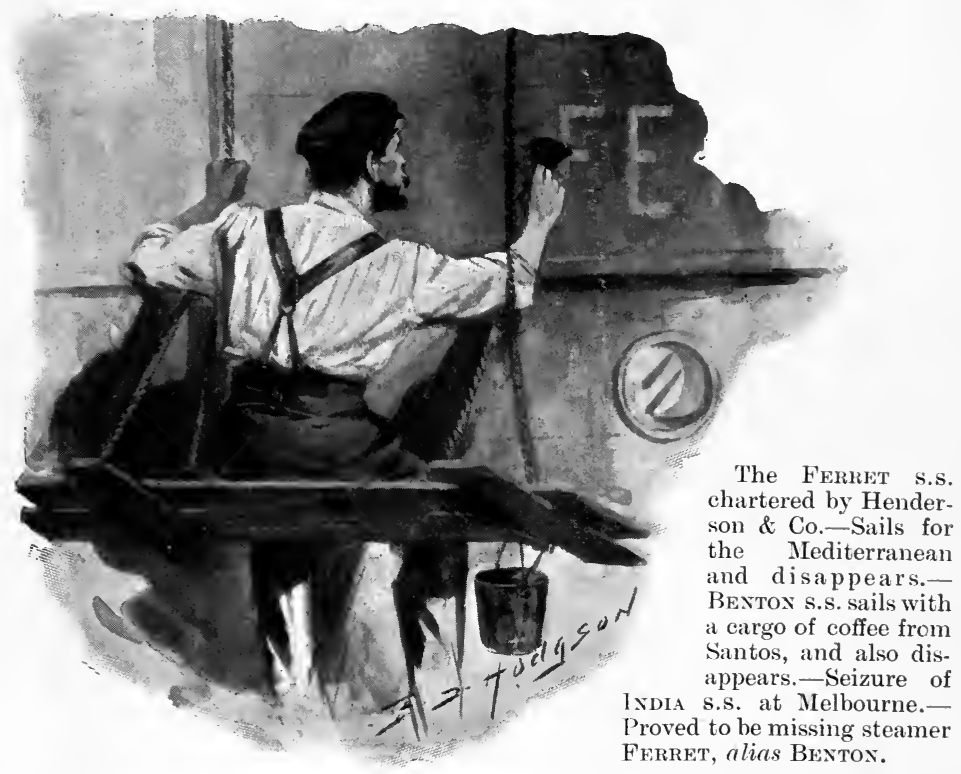

1)Ecideder the most dramatic incident ever recorded in the annals of steam navigation was the theft of the steamer FERRET and the piratical seizure and sale of her cargo of coffee.

The Ferret was a screw steamer measuring 170 feet 9 inches in length, 23 feet 2 inches beam, and 12 feet 7 inches depth; builders' measurement 439 tons, with a probable carrying capacity of 400 tons dead-weight cargo, in addition to coal in bunkers. She had compound engines of 90 h.p. nominal, and her reputed speed was 12 knots per hour. She was built on the Clyde in 1871, by the well-known firm of J. \& G. Thomson, for Messrs. G. \& J. Burns, of Glasgow, from whom the Highland 
Railway ('o. purchased her for their mail and passenger service, and she held a Board of Trade certificate for 200 passengers.

The conspirators who succeeded in stealing this vessel, laid their plans with great care and attention to details, and carried them out with marvellous audacity. One of them took an office in Gracechurch Street, London, and obtained a supply of printed stationery, describing himself as "Henderson \& Co., Ship Brokers, \&e." He also opened an account with the . . Bank, in the name of " Smith," taking care until his plans were perfected to keep a respectable balance to his credit.

Early in October, 1880, the plot had ripened, and one of the gang, representing himself to be "Mr. Walker, purser of the Ferrer s.s.," called at the office of Mouglas \& Co., Union Street, a leading ship-chandler's firm in Glasgow, and ordered a large quantity of expensive ship-stores. The stores were for the account of $\mathrm{Mr}$. Smith, who was referred to as a relative of $\mathrm{Mr}$. IV. H. Smith, late First Lord of the Admiralty.

Naturally references were required and were freely given. Mr. Smith had chartered from the Highland Railway Co. the steamer FERRET for a six months' cruise in the Mediterranean, his wife having been ordered by her doctor to take a long sea voyage. The Ferret was then in J. \& G. Thomson's yard, being overhauled preparatory to the cruise. Both of these firms could be referred to, as well as Mr. Smith's bankers, and Messis. Henderson \& Co., Ship Brokers, Gracechurch Street, London. The bankers were written to, and replied that Mr. Smith had an account with their bank. Henderson \& Co. were also applied to, and of course gave a very favourable account of Smith.

The merchants being satisfied with the result of their enquiries, supplied the stores, which included an excellent selection of first-class wines specially brought from London. 'The account, which amounted to $£ 1,490$, was presented to Walker, who gave a bill at three months endorsed by Smith. It is to be presumed that the first-half month's charter was paid as customary in casil in advance, because the conspirators having got possession of the FErRer were in no violent hurry to get her out of 13ritish waters. 
About the 20th October, William Griffin joined the steamer at Greenock as chief engineer. Although Griffin was not placed on trial, yet it is to be noted that he had a prior acquaintance with Walker, who had introduced him to Smith. It is also undeniable that without the assistance of Griffin and the ship's carpenter, the alterations which were made in the steamer could not have been effected.

From Greenock, the FERRET sailed in charge of a crew of "runners" to Cardiff, Robert Wright, alias Carlyon (a confederate) being master, and Walker, alias Wallace, acting as purser. The steamer arrived at Cardiff on the 22nd October and remained there for three days, taking in a cargo of coals for ship's use. The coals, of course, being paid for by valueless bills on London. At Cardiff the "runners" were discharged and a fresh crew, strangers to the Ferrer, were shipped. Smith. (otherwise Henderson) also embarked at Cardiff, accompanied by " Mrs. Smith."

The Ferres sailed from Cardiff on the 25th October and put into Milford Haven, probably from stress of weather, where she remained for about a week. She left Milford on the 1st November, ostensibly for Marseilles. In pursuance of this report, she passed through the Straits of Gibraltar on the morning of the 11th of the same month, and showing her number, requested to be reported.

Having steamed out of sight of the signalling station, the crew were set to work to change the colour of the funnel from white to black, and of the boats (with the exception of two) from blue to white, and at night, with her lights screened, the FerRet returned westwards through the straits. While passing through, the two boats that had not been altered, some empty casks, several life-belts, and other articles, all having the steamer's name painted on them, were thrown overboard, for the purpose of making it appear that the vessel had foundered. So evident did this seem that as a matter of fact the underwriters paid the Highland Railway Co. their claim for the total loss of the steamer.

That same night all the crew were sent aft to the saloon, where Smith made a speech to them, in which he stated that he 
was a political refugee from the United States; that he had purchased the FERRET to use partly as a yacht, and partly for trading; that after he had traded for some time he would sell the boat, and make it worth their while to keep his secret; but on the other hand, if any of them disclosed anything they saw or heard on board, he would blow their brains out. The crew, when arrested, alleged that it was the fear of this threat which prevented them giving information, when in port, of what they knew to be suspicious actions.

Avoiding the Canary Islands, presumably as being too much frequented by British shipping, the conspirators kept away to the southward until they reached St. Vincent, C.V. Entering

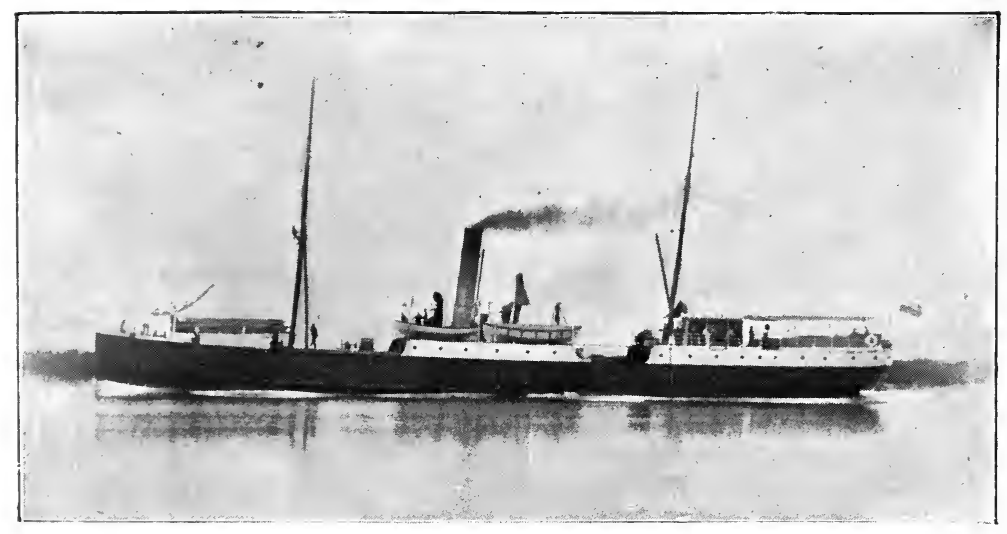

FERRET S.s.

the harbour, they anchored there for several days, during which they took in fresh water, and a supply of pigs, poultry, fruit and vegetables, paying for them in their usual manner by means of worthless bills.

The "T'imes" (23rd June, 1881) Sydney correspondent states that after leaving St. Vincent the vessel's name was altered to the Bexton. But this seems most improbable, as it would be apparent that the FERret did not founder in the Mediterranean, and further it would have left a clue by which she could easily have been traced. The truth probably is, that the alteration was made immediately she got clear of the Straits of 
Gibraltar. Be this as it may, the Benton s. arrived at Santos on the 26th December.

At Santos, Smith went on shore and lost no time in opening negotiations with the local shipping agents, to whom he stated that the Benton was from Cape Town in ballast, bound for England. The negotiations resulted in the shipment of 3,992 bags of coffee, consigned to various consignees at Marseilles. Having obtained this cargo, the BENTon sailed from Santos on the 11th January, 1881, but instead of proceeding to Marseilles she steamed direct to Cape Town.

While the Bentox was steaming across the South Atlantic, the Glasgow holders of the bill for $£ 1,490$ received some information which made them uneasy, and on presentation of the bill when due, it was dishonoured. The account was closed, the balance had been withdrawn, and the acceptor's whereabouts were unknown. The holders then applied to Henderson and Co., but the letter was returned-addressees "gone, no address." They then wrote to the Highland Railway Co., and received a reply from the Secretary to the effect that the Highland Railway Co. had already done all in their power to trace the FERRET, in their own interests, having received no charter money from the charterers since the vessel sailed from the Clyde. They had been in communication with Lloyd's and the Board of Trade, and through British Consuls and Lloyd's agents, enquiries had been made all over the world. About ten days before the receipt of the merchants' letter the Highland Railway Co. had heard that the Ferres had arrived at Malta, but on cabling there had received a reply denying the report. They had cabled a second time, ordering the vessel to be seized at Malta in the event of her putting in there.

Meanwhile the Bentor was nearing Cape Town, laden with coffee shipped at Santos. During the voyage further changes had been effected in the appearance of the vessel, and the name India was substituted for Bextor. The original name (FErRer) had previously been filed off the ship's bell, and now, as a further precaution the ship's number on the main hatch combings was altered to 77,942 . The Ixdia put into Cape Town on the 29th January, and at once began to discharge her cargo. 
The conspirators had provided themselves with a printing press, and had all necessaries on board, as well as Revenue Stamps of various nations, by which they were able to manufacture the vouchers and documents necessary to the success of their frauds. At Cape Town, Smith produced an invoice with a printed heading, purporting to be an invoice for 3,992 bags coffee sold by coffee planters at La Guayra (a small port in Venezuela) to C. S. Henderson \& Co., and with it a receipt for the amount duly stamped. He succeeded in selling the cargo, and realised by the sale of it about $£ 11,000$. He had to accept in part payment bills to the extent of $£ 8,000$, drawn on the Standard Bank, Clement's Lane, London, payable nine months after date. It is satisfactory to know that the frauds were discovered before the bills matured, and payment of them was stopped. After the discharge of the cargo, Smith tried to sell the steamer, but not succeeding in his attempt, he shipped a quantity of coal, and sailed on the 14th February for the Mauritius. The conspirators arrived at Mauritius on the 1st March, but did not succeed in getting any plunder there, and so they "cleared out for Guam."

The next port they entered was Port Albany in Western Australia, from whence they steamed direct to Melbourne. Here Wright and Walker offered the steamer for sale, but received no offers. While in Melbourne, several circumstances made the Customs officers and the Harbour Police suspect that there was something wrong about the vessel. It was observed that the fires were always banked so that steam could be got up at the shortest notice. Captain Wright never left the steamer, and none of the crew (except Walker, the purser) were ever allowed "shore leave." The Customs authorities instructed one of their officers to make a special investigation of the matter, and he reported that there was no steamer of the tonnage given registered at Lloyd's in the name of Ixdia, but that the particulars of tonnage and dimensions corresponded with the register of the missing steamer FERrEt.

Noting all these suspicious circumstances the Customs authorities determined on prompt action. Requisitioning two crews of the Water Police, as it was feared there might be 
violent opposition on the part of the steamer's crew, the Commissioner of Customs, on the 2⿰氵th April, seimed the vessel. Fortunately their anticipations as to resistance were not realised, the crew surrendering without opposition. Although the authorities had been extremely cautious in their enquiries, it is evident that the conspirators became aware of what was

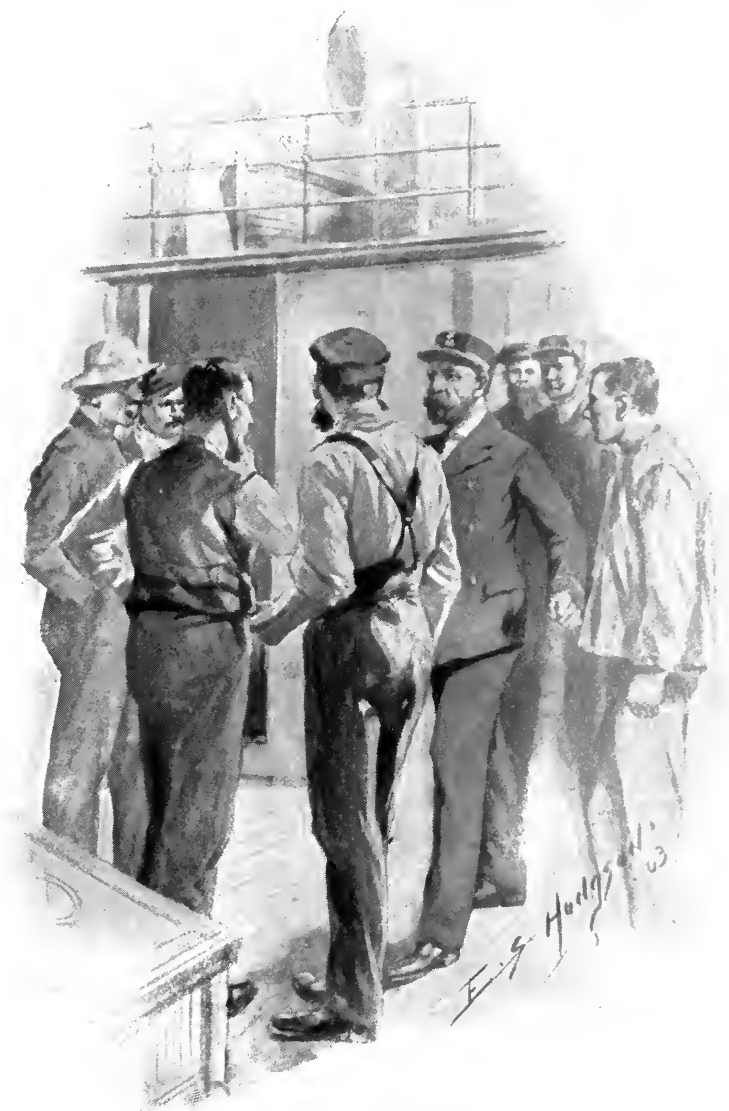

The Arrest.

being done, for when the steamer was seized, Smith, "Mr's. Smith," and Captain Wright had fled. The previous day Smith and Mrs. Smith removed from their cabin a number of articles, and amongst them two heavy iron-bound boxes which were never traced. Smith succeeded in getting away from Mel- 
bourne to a distant township, but was arrested. Mrs. Smith, who had disappeared for a time, when she heard of his arrest reappeared and visited him in prison. The object of her visit may be surmised from the fact that shortly after her visit Smith tried to escape by filing through one of the bars of his prison window.

Captain Wright had found a retreat in a Melbourne sailors' lodging-house, but having got drunk and quarrelled with his landlady, he was thrown out, and arrested for being drunk and disorderly. When the charge was being booked at the police station, he was recognised as the missing master of the steamer, for whom the police were searching.

Confirmation of the suspicions which induced the Commissioner of Customs to seize the steamer was speedily obtained. Traces of fraud were quickly discovered on the ship's hull and appointments, and in the ship's books and papers-some of the latter being found in very unusual places of deposit. Between the leaves of the log-book a seaman's "advance note" was found with the name of the Ferres on it. There was also found a MSS. cypher code, by means of which communication might be made between those in the vessel and others on shore. It also serves to show the unscrupulous character of the criminals and the extreme length to which they were prepared to go. One or two quotations will illustrate the truth of this assertion :-

"Accept charter referred to and lose vessel before you arrive in port. Don't fail."

"Get out of port the best way you can, but sink the ship, before you allow them to stop her."

"Destroy all papers, \&c., and sink ship if possible, or burn her, and get away. Make best of your way over here."

"Things going wrong. Mate not to be trusted; shall get rid of him."

"Things going wrong with some of the crew ; must get rid of them."

"Things going wrong with the whole of the crew; must get rid of them."

"Lost vessel ; landed here to day ; all hands forward lost." 
"Game is all up: all discovered ; destroy or hide everything, and make yourself scarce: communicate with me through the arranged channel."

Among the papers seized was a card of a 1)r. Bonefin. Now a swindler of this name-not a common one-shortly before the arrival of the FERRET, was convicted for obtaining goods under false pretences from a number of Melbourne jewellers, and was sentenced to a term of imprisonment in Pentridge Gaol. In the cypher code referred to Melbourne figures as 51, so that it is extremely probable that Bonefin was one of the conspirators on shore.

A Cabinet Meeting of the Victorian Government was held on the 9th May, and on the following morning the opinion of the Attorney-General was published as follows:-

"The Government of Victoria seized the Ferret, which "entered this port (Melbourne) as the Ivira, in the " interests of the rightful owners, domiciled apparently in "Great Britain. At the present time no one in Victoria " is in a position to show this Government such a title to " the FerRet as would clear the Government from possible "liability. It appears to me that the Hon. the Commis"sioner of Trade and Customs should hold the FERret " till proper papers are produced in Melbourne by a legally " authorised agent of the actual owners, whose title should " be clearly proved by the needful papers from England. "This being done, and delivery charges paid, the ship " should be delivered. If it is deemed desirable to " expedite delivery of the ship, this Government is entitled " to require that the Board of Trade of London should "give a certificate as to the owners. Such certificate, "along with an indemnity to pay all costs, and an " indemnity by the owners, should be deposited with the "Agent-General for Victoria, London, who should tele"graph any instructions the owners may wish to give as to "the way they desire the ship to be dealt with, and this "Government should then act accordingly. At the same "time it would be well to learn whether the Imperial "Government wished to take proceedings against any of $\mathrm{K}$ 
" the offenders, and if so, what course it intended to take.

"All necessary documents and evidence should be

" transmitted without delay. The master, also the person

"who represents himself as the owner, and another person

"are charged here with forging the register of the ship,

"that offence having been committed with a view to a

"fraudulent sale."

Eventually the three criminals arrested, viz.:-Smith (alias Henderson, alias Benard), Wright (alias Carlyon) and Walker (alias Wallace), were indicted on three counts:-

1st. Conspiracy to defraud the owners of the FERrET, the Highland Railway Co.

2nd. Conspiracy to defraud intending purchasers of the Ferret in Melbourne; and

3rd. Conspiracy to deceive the Commissioner of Trade and Customs, by entering the vessel in a false name, and to obtain a certificate of sale under which the vessel could have been sold in that port.

They were all acquitted on the first count, but convicted on the second and third. Smith and Walker were each sentenced to seven years' penal servitude, and Wright to three and a half years. This result is most remarkable. No mention is made of the frauds perpetrated at Glasgow, Cardiff and St. Vincent, C.V.; nor of the steps taken (if any) to secure the confederates on shore.

Is for the unfortunate crew, who had received no wages, they obtained a temporary refuge in the Melbourne Sailors' Home. The after history of the FERRET is briefly told. She was purchased in 1885 by the Adelaide Steamship Company, Currie Street, Adelaide, South Australia, and is at the present date employed by that company in the Australian coasting service. 


\section{Chapter Nitis.}

Anglo-Canadian Steamship Companies.-Allan Line.-Canadian Pacific Railway Co.-Dominion Line.

Foldowing the example of the Imperial Government the Government of Canadla advertised in June, 1852, for tenders for the conveyance of mails between the United Kingdom and Quebec and Montreal in summer, and between the United Kingdom and Portland, Maine, in winter. The contract was secured by Messrs. McKean, McLarty and Lamont, of Liverpool, who formed a company, and despatehed their first steamer, the Gexova, a small vessel of 500 tons register, in the spring of 1853. The sailings were continued, but with no great regularity, for about eighteen months. In addition to the steamer named, the Cleopatra, of $146 \mathrm{r}$ tons, the OTTaWA, and two chartered steamers, one the Charitr, built for the African Steamship Co., and the other the Caxaniax, chartered from Messrs. Allan Brothers, were engaged in the service. On the outbreak of the Crimean War the OtTawa and Charitr were taken off the Canadian service for the conveyance of troops to the Crimea, and in 1855 the ('Leopatra was despatched from London to Melbourne.

The Anglo-Canadian Mail Service proving unprofitable a natural result from the way in which it was conducted-it was transferred to the Messrs. Allan, who undertook to build a fleet specially for this trade, and to maintain a fortnightly service to Quebec in summer, and a monthly service to Portland, Maine, in winter, for the annual subsidy of $£ 2+, 000$. The Allan mail service to Canada eommenced in April, 1856. A weekly service was instituted in 1859, and has been continued until the present day. The first four steamers of the line were built by Messrs. Denny, Dumbarton, and one of them, the Axgro-Sixor, made a passage in nine days five hourswhich was considered a record in those days. The II IbErisix, 


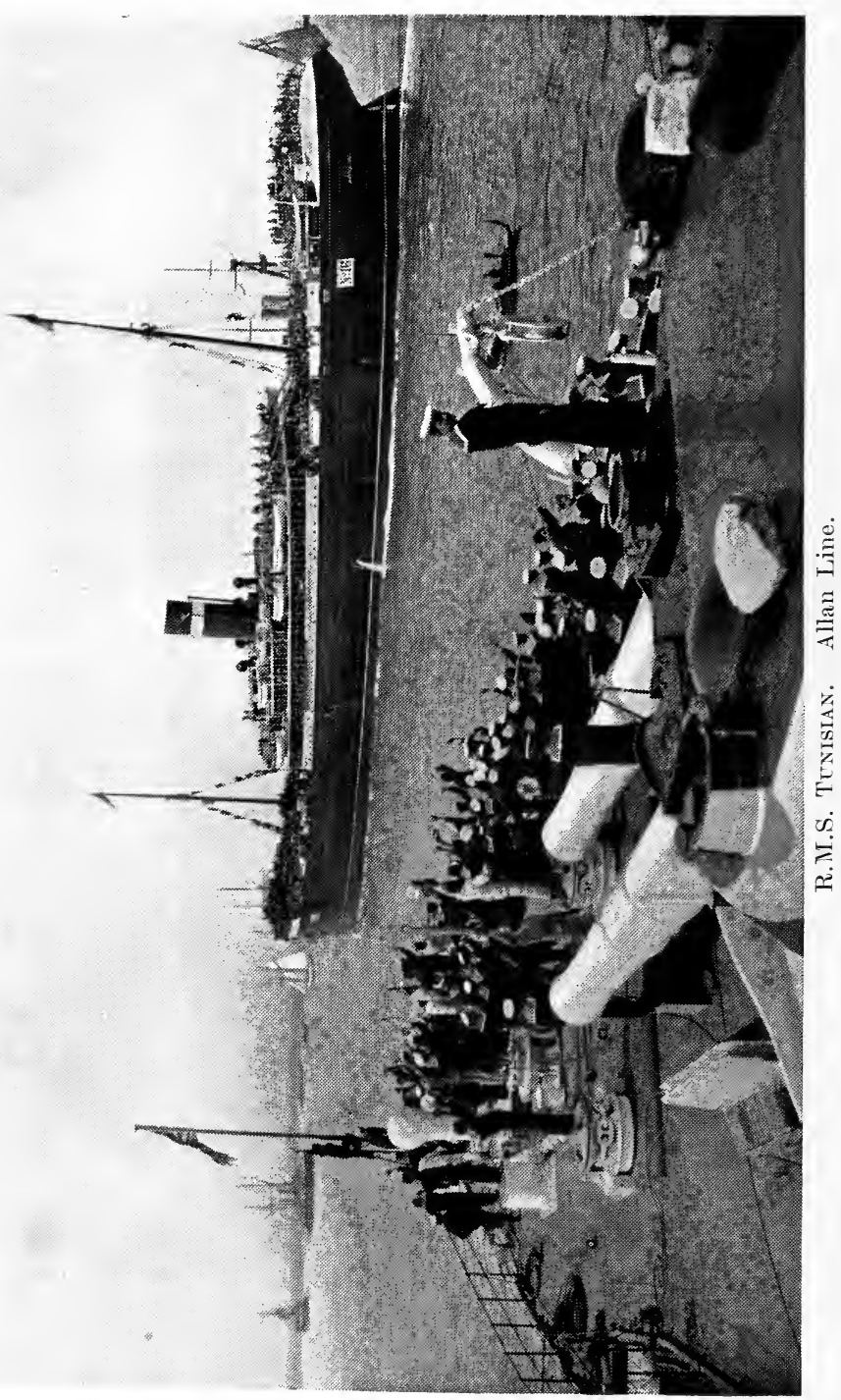


built in 1861, was the first steamer in the Atlantic trade to have a spar deck, covering the main deck from stem to stern, aftording shelter for the passengers in heavy weather, and found to be so advantageous that it has been adopted by all the other first-class Atlantic companies.

The time on passage was further reduced by the Polrswsias in 1872. On her first voyage this steamer made the passage between Quebec and Londonderry in seven days eighteen hours and fifty-five minutes.

In $18 \pi 5$ the Bunos Ayrear made her appearance. This vessel is remarkable as being the first Atlantic liner constructed of steel, the material of which all ocean-going steamer's are now built.

In 1881 the Parisian was launched, a steamer which has always been a favourite on the route. She has accommodation for 200 first, 100 second, and 500 third-class passengers, and is popularly known as the "ladies' ship," a title bestowed upon her because she is credited with having carried a larger proportion of lady passengers than any other line. The three crack boats of the present fleet are the twin-screw steamers Bavariax, Tunisiax, and Ioniax. The first of these sailed on her maiden royage to Canada in August, 1899, and she was followed by the T'uxisiax in April, 1900. The Ioxiax, the latest addition to the passenger fleet, is a twin-screw steamer of 9,000 tons. So far as outward appearance and internal arrangements go these are sister ships, though the T'UNisiax is 10,576 tons, against the 9,000 tons of the Ioxiax.

The dimensions of these magnificent steamships are as follows:-length 520 feet, beam 60 feet, and depth 43 feet.

All the passenger vessels of the Allan fleet are lighted by electricity, and they are being fitted with the Marconi system of wireless telegraphy.

The new ship (to be named the Victoriax), now being built for the line in Belfast is to be supplied with Turbine Engines. she will be the first transatlantic liner to be fitted with marine engines of this type.

By its recent purchase (1903) from Messrs. Elder, Dempster and Co., of fifteen large and full-powered ocean steamships, 
the Canadian Pacific Railway Co. has placed itself in the front rank of steamship owners. Prior to this deal, it owned the steamers Aliberta, Atrabasia, Manitoba, Michigan, and Oxtario, all of which plied on the great inland lakes of Canada as adjuncts to its train services. These steamers ranged from 498 tons net register to 2,768 tons.

In 1891, the Naval Construction and Armaments Co., at Barrow, built three magnificent mail and passenger steamers for the Canadian Pacific Railway. These steamers, the Empress of China, Empress of India, and Empress of J J are almost identical in measurement, capacity and speed. They are each 455 feet 6 inches in length; 51 feet 2 inches beam; and 33 feet 1 inch depth of hold. They are propelled by twin screws driven by a pair of triple expansion engines of $1,16 \pi$ horse power. These three steamers have maintained since 1891, a regular mail service between Vancouver, B.C., the Pacific terminus of the Canadian Pacific Railway, and Japan and China.

The steamers Tartar and Athenian, two smaller and less powerful boats are despatched, as intermediate steamers, at regular intervals.

From Liverpool to Hong Kong-over sea and over land-the Canadian Pacific Railway Co. stretches a long unbroken line nearly 12,000 miles in length.

In 1870 Messrs. Flinn, Main \& Montgomery despatched the Sт. Lours from Liverpool to New Orleans. She was the pioneer steamer of a Company promoted by the firm named for the purpose of trading between Liverpool and New Orleans, and called the Liverpool and Mississippi Steamship Co. The views of the promoters becoming enlarged, they changed the name of the Company in 1872 to the Mississippi and Dominion Steamship Co., and entered into the Canadian trade. For many years the steamers of the Line sailed only between Liverpool and Quebec and Montreal, but about 1891 a second service was established, with sailings to and from Bristol and the ports on the St. Lawrence.

In 1894 Messr's. Flinn, Main \& Montgomery retired, and the two sections of the business were taken over-the Liverpool 
service by Messrs. Richards, Mills \& Co., and the Bristol service by Messrs. Elder, Dempster \& Co.; the former continued to be known as the "Dominion Line," but the latter service was merged into the Beaver Line, and as such formed part of the fleet purchased by the Canadian Pacific Railway Co., referred to in a preceding paragraph.

In 1902 the Dominion Line was acquired by the American Shipping Combine, and in October, 1903, a further change was made by the transference of the latest and best steamers of the fleet to the White Star flag. 


\section{Chapter XXIY.}

Railway Companies as Steamship Owners.- South Eastern and Chatham.London, Brighton and South Coast.-London and South Western.-Great Western.-London and North Western.-Lancashire and Yorkshire.Stranraer and Larne.-Caledonian.-Glasgow and South Western.-North British.-Great Central.-Great Eastern.

There are in Great Britain, as well as in the United States of America, many steamship lines which are either owned or controlled by railway corporations. On the south coast of Fingland, from Harwich to Falmouth inclusive, almost the whole of the Anglo-continental passenger traffic is held by the great railway companies, who have made the various ports along that stretch of coast their termini. In the North Country, both on the east and west coasts, with a few important exceptions, the cross-channel and over-sea traffic is operated by steamship companies, which, while running in connection with the railway systems of their respective ports, are entirely separate and independent undertakings.

The South Eastern and Chatham Railway Co. has now rumning between Dover and Calais, the new turbine steamer The Quens, and the fast and large paddle steamers Empress, Victoria, Dover, Calais, Lord Warden, Le Nord, and Le pas de Calais.

In connection with the same Company's service via Folkestone and Boulogne, the fast and powerful steamers Mabei. Grace, Princess of Wales, and Duchess of York are employed.

The London, Brighton and South Coast Railway Co. has also added this year (1903) a turbine steamer to its fleet of fast steamers plying between Newhaven and Dieppe. In addition to the turbine steamer referred to, the fleet at present includes the following powerful 21-knot vessels:-Arundel, Calvados, Paris, Rouen, and Trouville.

The London and South Western Railway Co. has a large fleet of about twenty powerful steamers, with which it main- 



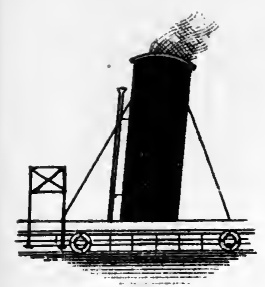

Stotт \& Co.
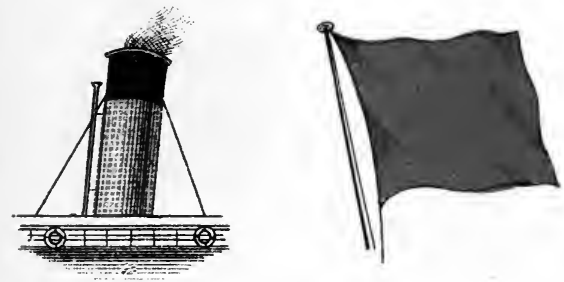

LeYLAND Line.
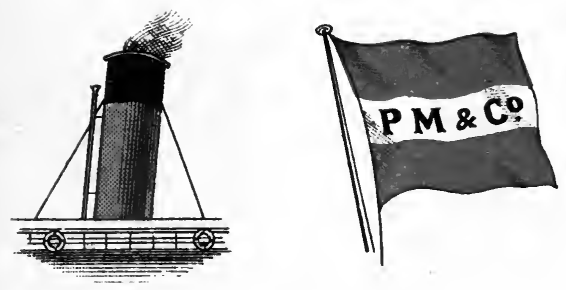

Palgrave, Murphy \& Co.
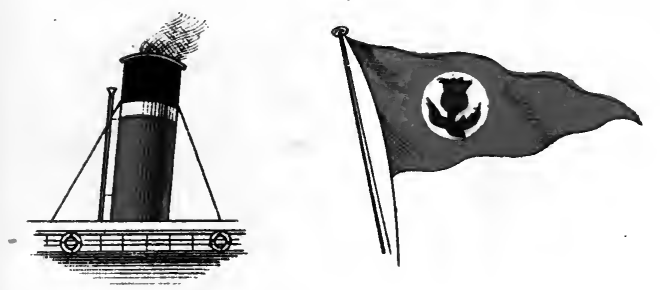

N. B. Ry. Co.
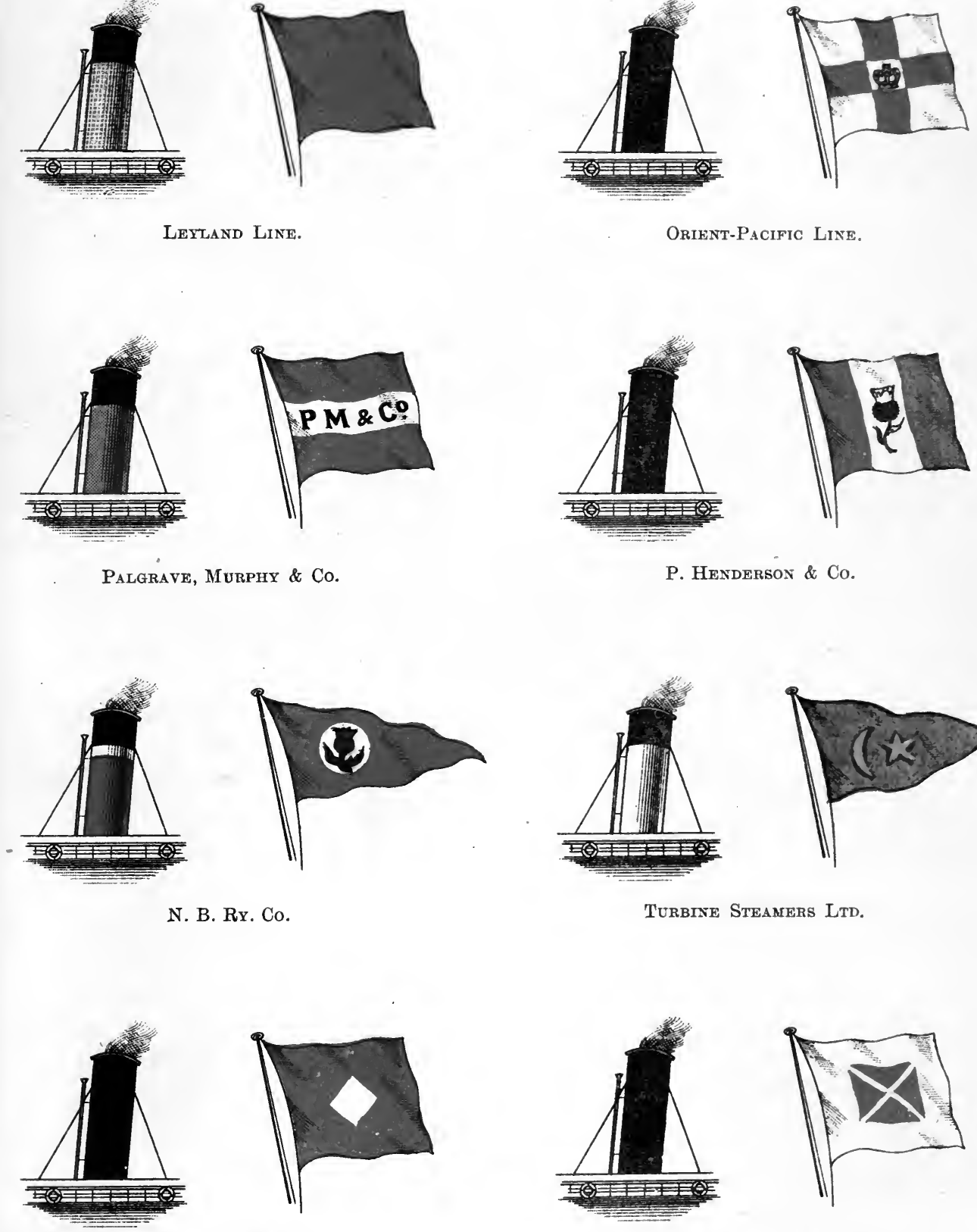

Orient-PACific Line.
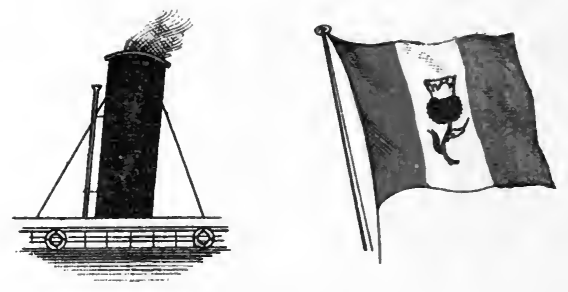

P. Henderson \& Co.

Turbine Steamers Ltd.

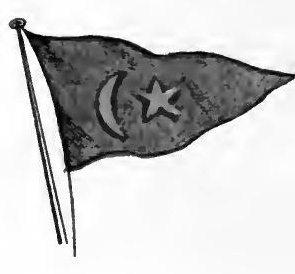

T $\mathrm{H}$ WEISFORD \& CO 

tains daily services between Southampton and Havre and tri-weekly services between Southampton and C'herbourg, and Southampton and the Channel Islands.

The Great Western Railway Co. from its southern terminus,

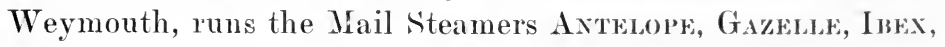
Lyxx, Reindeer, and Rosick, to the Chamnel Islands and Brittany; and from its western terminus, Milford, the Mail Steamers Great Westers, Limerick, and Waterford, to Waterford.

From Holyhead the London and North Western Railway Co. maintain passenger services to Dublin and Greenore. It

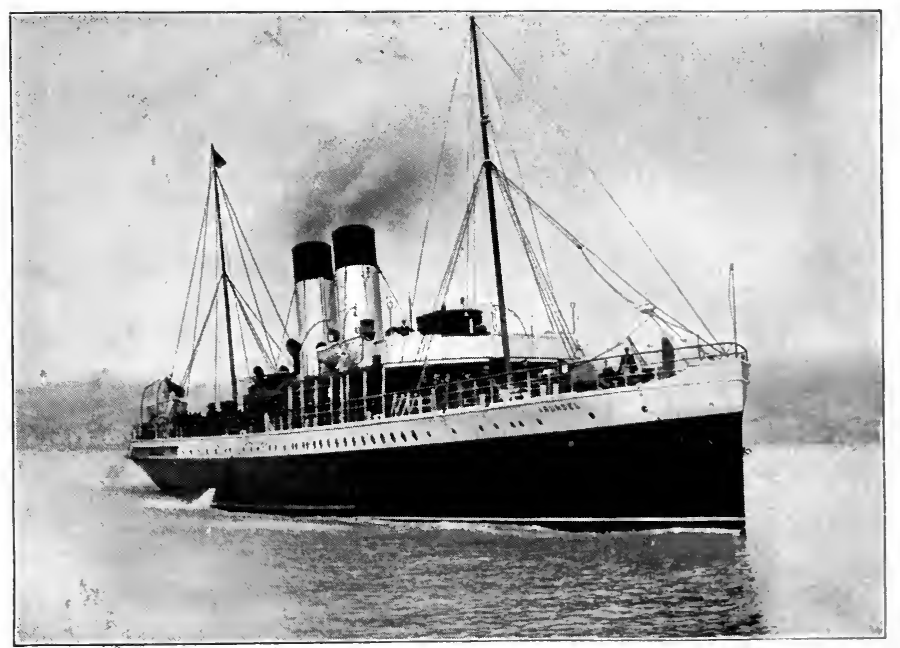

Arundel. London, Brighton and South Coast Ry. Co.

is also interested with the Lancashire and Yorkshire Railway Co. in the Mail Steamers sailing nightly between Fleetwood and Belfast.

In 1902 the Lancashire and Yorkshire Railway Co. purchased from the Drogheda Steampacket Company, for the sum of $£ 80,000$, the entire fleet of the latter Company, consisting of five paddle steamers engaged in the Liverpool and Drogheda Service. The Drogheda Steampacket Company was one of the oldest Irish steampacket companies, having maintained a steampacket service between Liverpool and Drogherla for 
upwards of sixty years. The Lancashire and Yorkshire Railway ( $\circ$. is also a partner in the Fleetwood and Belfast Mail Siervice, and has recently extended the sailings of the Fleetwood steamers to Londonderry.

A Joint ('ommittee representing several railway companies operate a Mail Service between Stranraer and Larne. The paddle steamer Princess Victoria or Princess May sails twice daily during the summer months, and once daily during the winter months to and from Stranraer and Larne, making the passage each way in about two hours.

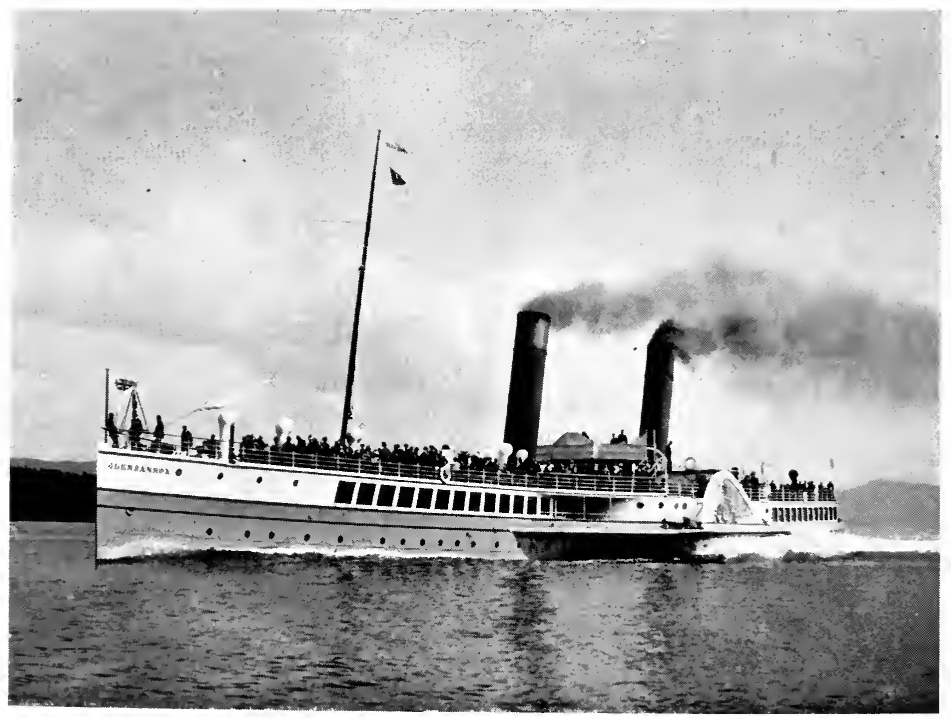

Glen Saxnox. Glasgow and South-Western Ry. Co.

(On the Firth of Clyde the Caledonian Railway Co. are interested in the handsome steamers of the Caledonian Steam Parket Co. These vessels carry a cream coloured funnel, and sail from Ardrossan to Gourock and Wemyss Bay. All the watering places on the Firth are served by the respective fleets of the various railway companies.

The Glasgow and South Western Railway Company owns, 
and works from Prince's Pier, Gourock, a fleet of swift steamers distinguished by their slate coloured hulls, with red funnels and black tops. The fleet includes the Guex Rosi, Giex

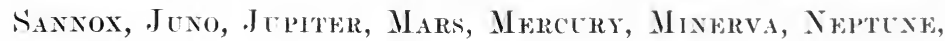
and others.

'The North British Railway Company is the premier Railway Company of Scotland; its mileage amounts to 1,$30 ; 3$ miles. In conjunction with the Great Northern and North Eastern Railway Companies it forms the "East Coast Route" from England to Scotland, and the fastest booked " Railway run" in the Kingdom is on this route. As an important adjunct to its railway system, the North British Railway Co. employ on the Firth of Clyde (making Craigendoran the headquarters),

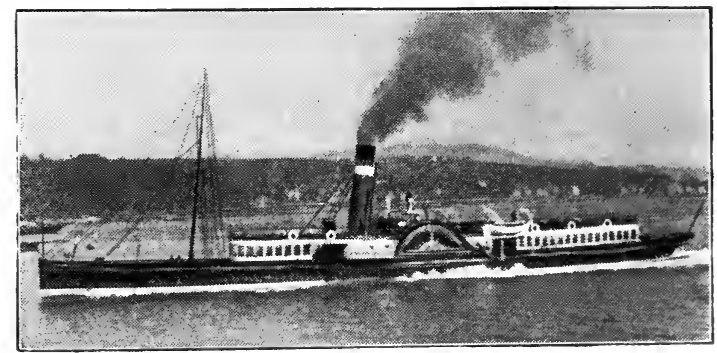

Lecy Ashtox. North British Ry. Co.

the well-known paddle passenger steamers LADY CLARF, LADY Rowera, Lucy Ashton, Ren Gauntlet, Talisman, Wavercey, and others; and between Silloth and Liverpool the screw cargo steamers Albatross and Kit'tiwake.

No Railway-owned steamers ply on the east coast of Scotland, but from Grimsby the Great Central Railway Co. have a large fleet of passenger and cargo steamers sailing regularly to various continental ports. In July, 1865, this Company (then known as the Manchester, Sheffield and Lincolnshire Railway Co.) purchased the Anglo-French Steamship Co.'s fleet of boats, and started running steamers from Grimsby to Hamburg. The following April the Railway Company commenced a service of steamers between Grimsby and Rotterdam, and in 
August, 186\%, the service was extended to Antwerp. At the present time the Great Central Railway Co. possesses a fleet of fourteen powerful steamers trading regularly between Grimsby and the continental ports named.

The railway company remaining to be mentioned as a steamship owning company is the Great Eastern Railway Company - the Royal British Mail Route to Holland.

The steamers of this Company have been especially built for the Continental service. The Royal Mail steamers Austerdan, Berlin, Chelumsford, Dresden, and the Vienna, run on the Harwich-Hook of Holland route. They are powerful twin-screw ocean-going ships of 5,000 indicated horse-power, capable of steaming 18 knots an hour, each with two distinct sets of engines, so that in case of accident to one set the vessel can proceed with the other.

The passenger accommodation is similar to that on the latest Atlantic Liners, a special feature being the large number of private cabins for two passengers. The ships are fitted with electric light, and all latest passenger comforts, including dining, smoking, and ladies' saloons, and separate sleeping berths.

The vessels running on the Harwich-Antwerp route are similar to those on the Hook of Holland service.

In common with all Railway Companies' steamers, the Company's vessels sail under the British flag, and are subject to the British Board of Trade stringent regulations as to safety and life-saving appliances.

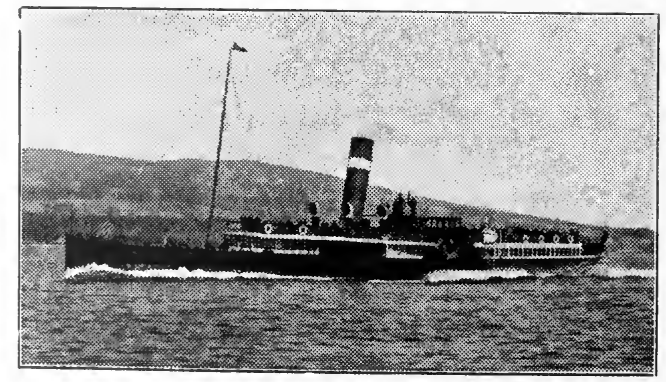




\section{Chapter XXY.}

Turbine Steamers.-Turbinia.-King Edward.-Quefe Alfixandra.The Quefi.-The Eneralid.

The latest development of the marine engine is the Marine Steam Turbine, the invention of the Hon. C. A. Parsons, F.R.S., brother of the present Earl of Rosse, and a son of the builder of the famous "Birr" telescope, the largest reflecting telescope ever built.

The first vessel ever fitted with the new type of engine was appropriately named the Turbixia. This vessel is only 100 feet long by 9 feet beam and of a total displacement of $44 \frac{1}{2}$ tons, but she is some ten knots faster than any boat afloat of the same dimensions. Although the weight of her main engines is only about 4 tons, and the total weight of machinery, screws, and shafting, tanks, etc., is only 22 tons, she developes the enormous power of 2,100 I.H.T., being almost 100 H.P. per ton of machinery.

Prof. Ewing, in April, 1895, made some trials of the Turbisia on the Tyne, the highest speed then recorded being $32 \cdot \% 5$ knots, but in .June of the same year a speed of $34 \frac{1}{2}$ knots was obtained at Cowes.

Three turbines are used for driving the vessel--high pressure, intermediate and low pressure. Each turbine driving direct on to a separate propeller shaft. Reversing is obtained by means of one or more separate turbines connected to the same shafts as the propelling turbines and working in a vacuum when the boat is going ahead.

Several torpedo destroyers and three yachts have been fitted with Parsons' turbine engines. The first mercantile vessel to be so fitted was the King Enward, built by Messis. Denny Brothers, Dumbarton, in 1901.

On her trial trip she attained a speed of $20 \frac{1}{2}$ knots, and during her first season on the Firth of Clyde (1901) she sailed 
12,116 knots in 79 days on a coal consumption of 1,429 tons, at an a verage speed of $18 \frac{1}{2}$ knots per hour. So satisfied were her owners with her, that they gave an order to the same builders and engineers for a somewhat larger vessel for the following season.

The new (1902) turbine steamer is the Quenn Alexandra, a three-deck passenger steamer intended also for the Firth of ('lyde passenger service. She is $2 \pi 0$ feet long, by 32 feet beam, and depth 11 feet 6 inches. She has two funnels, but only one pole mast. Her main deck is completely covered in from the bow to aft of the engine room, and above the spar deck she carries a shade deck 100 feet in length, to which passengers have access, and under which shelter is provided in wet weather.

Like her sister vessel, the King EDward, the main engines of the Queen Alemandra consist of three separate turbines, each driving its own shaft, the centre turbine being highpressure, and the two side turbines low-pressure. The velocity of the centre shaft is about 700 , and of each of the side shafts 1,000 revolutions per minute. On account of the high velocity at which the shafts revolve it is necessary to increase the number of propellers driven, and the turbine steamers, therefore, have five small propellers each, one on the centre shaft, and two each on the outside shafts. On the builders' trials the Queer Alexandra exceeded the speed of the King LDward by a knot and a quarter. Her actual speed was 21.63 knots, equal to about 25 miles per hour.

Two Channel steamers designed to carry passengers and mails, and to be fitted with Parsons' marine steam turbine engines, are now (190:3) being built on the Clyde by Messrs. Wm. Denny and Brothers.

() these, one, the Queser, is to the order of the South Lastern and Chatham Railway Co. She will be 310 feet long and 40 feet broad; and she is to maintain a speed of at least 21 knots. The average time occupied at present on the passage between Dover and Calais is 65 minutes, but the new vessel is expected to reduce the time to 50 or even 45 minutes.

The mode of propulsion is practically the same as that on 
the Quker Alwasina, namely, three shafts carrying five propellers.

The other Chamnel steamer referred to as being built is intended for the London, Brighton and South Coast Railway Co.'s service between Newhaven and Dieppe. Her dimensions are, length 280 feet, beam 34 feet, draft 22 feet; with a gross tomnage of 1,100 tons.

The Emerald, one of the three yachts referred to at the beginning of this chapter, is the first vessel fitted with turbine machinery that ever crossed the Atlantic. She arrived at New York, after encountering tempestuous weather on the passage, on the 6th May, 1903. Her qualities as a sea-boat were severely tested during the voyage, with entirely satisfactory results. She was built for Sir Christopher Furness, M.P., by Messrs. Alex. Stephen \& Sons, Limited, of Linthouse, and fitted with machinery by the Parsons Marine Steam Turbine Co., Limited, of Wallsend-on-'Tyne, and it was found that when the yacht was steaming at the rate of 15 knots per hour, the machinery ran with an absence of vibration and noise.

The EMERALD is a vessel of 756 tons, yacht measurement, and was chartered by Mr. Geo. Grould, of New York, for six months from the 15th April, 1903. Mr. Gould sent over to this country Captain Tod to navigate her across the Atlantic, with instructions to further experiment on her steaming capabilities at sea, and to carefully observe her behaviour compared with the other large steam yachts of which he has had charge. On the termination of the voyage, Captain Tod reported that the yacht behaved splendidly; that there was no racing of propellers, and no vibration; and that the coal consumption was moderate, considering the weather.

There have been several rumours to the effect that the new steamers for the Cunard Mail Service are to be fitted with turbine engines, but these rumours have not been officially confirmed. In any case these steamers could not be completed in time to take from the Allan Line the distinction of being the first Company to own a Transatlantic Mail Turbine Steamship. 




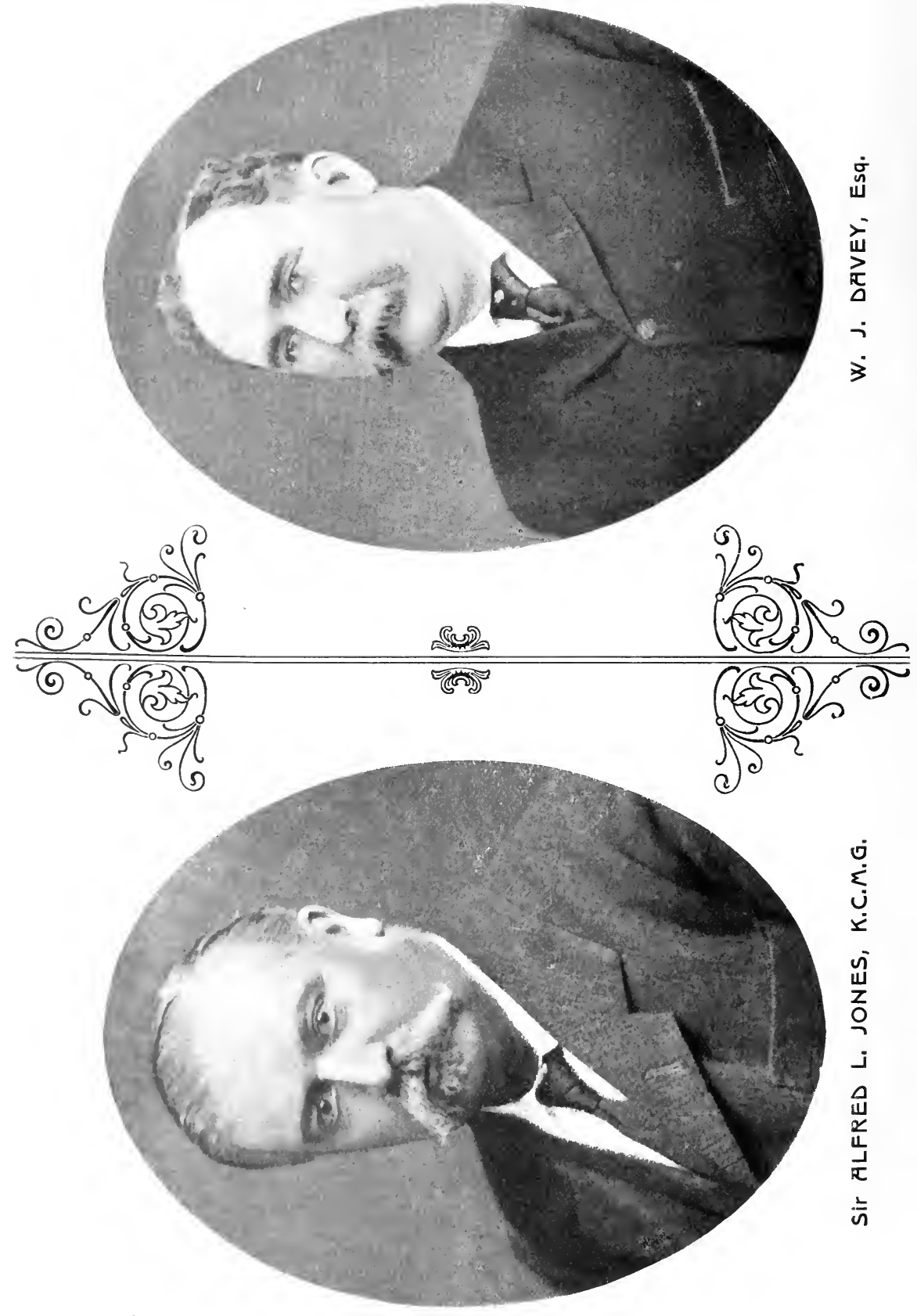




\section{History of Steam Navigation.}

Part II.

HISTORICAL STEAMSHIP COMPANIES.

Chapter I.

MESSRS. EI.DER, DEMPSTER \& CO.

The firm of Elder, Dempster \& Co. was founded in the year 1868 by Messrs. Alexander Elder and John Dempster, two gentlemen intimately acquainted with the working of the African Steamship trade. For 11 years they were the sole partners, but in 1879 they admitted Mr. (now Sir Alfred) Jones into the firm, and Mr. W. J. Davey was also taken into partnership. The original partners, Messrs. Elder and Dempster, retired from the firm in 1884. Mr. Alexander Sinclair, who became a partner in 1891, having retired in 1901, the sole partners at the present date are Sir Alfred L. Jones, K.C.M.G., and Mr. W. J. Davey.

The firm is one of the largest commercial houses in the world, and in all the various branches of commerce in which it is interested it takes a foremost position. As steamship owners it controls the largest fleet of steamers in Great Britain. The business of the firm extends so rapidly, and new steamers to meet the necessities of the several trades are so frequently being added to the fleet; that it is impossible to give a list of the vessels owned, or under the management of the firm, which will not in a short time be obsolete, but according to the official sailing list issued 28th March. 1903, 
the following steamers were sailing under the triple flags of Messrs. Eller, Dempster \& Co.:-

\begin{tabular}{|c|c|c|c|}
\hline ABEOKUTA. & Cameroon. & Lake Megantic. & Mount Royal. \\
\hline ACCRA. & Coomassie. & LAKE Michigan. & Mount Temple. \\
\hline ADANSI. & Congo. & Lake Ontario. & Nigeria. \\
\hline AKABA. & DAHOMEY. & Lake Simcoe. & Nyanga. \\
\hline AKASSA. & Degama. & LEON-Y-CASTILlio. & OLENDA. \\
\hline AlBERTVILLE. & Delta. & LOANDA. & Oron. \\
\hline ANCOBRA. & Dono. & LOANGO. & Perez Galdos. \\
\hline ANDONI. & EGGA. & LYCIA. & Phillifipeville. \\
\hline ANVERSVILLE. & EGWANGA. & LLANDULAS. & Port Antonio. \\
\hline ANGOLA. & Еко. & MADEIRA. & Port Maria. \\
\hline ASABA. & Eкuro. & Mandingo. & Port Morant. \\
\hline Ashanti. & Elmina. & Mayumba. & Port Royal. \\
\hline Axim. & EтHIOPIA. & Melville. & Prah. \\
\hline BAKANA. & Etolia. & Memion. & ROQUELLE. \\
\hline BANANA. & Fantee. & Milwaukef. & SANGARA. \\
\hline BATHURST. & ForCADOS. & Monmouth. & SANSU. \\
\hline BATANGA. & Haussa. & MoNROVIA. & SEKONDI. \\
\hline Bengufla. & IDDO. & Montauk. & Sherbro. \\
\hline BENIN. & ILARO. & Monteagle. & Sово. \\
\hline BIAFRA. & ILORIN. & Montezuna. & TARQUAH. \\
\hline BIDA. & JEBBA. & Montreal. & TENERIFFE. \\
\hline Boma. & Kano. & Montrose. & Viera-y-ClaviJo. \\
\hline Bonny. & KWARRA. & Monarch. & VoLTA. \\
\hline Bornu. & LAGOON. & MontCalm. & WARRI. \\
\hline BOUlaya. & Lake Champlain. & Montenegro. & YoLA. \\
\hline Burutu. & LAKE ERIE. & Monterey. & YoRUBA. \\
\hline CaBenda. & Lake Manitoba. & MontFort. & \\
\hline
\end{tabular}

As proving the difficulty of stating the number of steamships under the control of this firm, and at the same time illustrating the gigantic nature of its commercial operations, it may be stated that while this volume was in preparation for the Press, it sold to the Canadian Pacific Railway Co. an entire fleet, consisting of fifteen large ocean liners. The despatch of the last Elder-Dempster liner under the Beaver flag, on Wednesday, March 31st, 1903, was quite an historic event. She carried with her the first portion of the Rev. J. M. Barr's colony, numbering about 2,000 souls. Thousands of spectators lined the stage, and as the liner sheered away cheer after cheer rent the air. Sir Alfred Jones, Mr. W. J. Davey, Mr. David Jones, the Revs. Canon Russell (Manchester), R. O. Greep, Dr. Lightwood, S. Gasking and H. M. Braithwaite, as well as many 
well-known personages in shipping and commerce, were present. The band of the 1st Liverpool Volunteers played inspiring music, including tunes reminiscent of home and friendly associations, first on the stage and afterwards on the ship.

Sir Alfred Jones expressed his regret, as he witnessed the multitude on board the Lake Manitoba, that he had consented to sell his Canadian fleet to the Canadian Pacific Railway. He said his firm had worked hard to develop Canadian colonisation, and the full fruit of their efforts was only becoming visible now when they had left the business. He commended the object of the expedition, and hoped for its success. A completely equipped colony of 2,000, with thousands more to follow in due course, was, he considered, a novelty.

Reference has been made to the three flags borne by the Elder-Dempster steamers. The Beaver flag no longer exists. The other two are (1) the white swallow-tail flag with a red St. George's cross (gold crown in centre) of the African Steamship Co.; and the blue swallow-tail flag, with a white St. George's cross, of the British and African Steam Navigation Co. A brief sketch of the history of both of these important companies, as well as of the Imperial Direct West India Mail Service Limited, will be found in the succeeding pages of this volume.

The management of any one of these fleets would be considered ample employment for most mercantile firms, but they are only units in the business conducted at that large hive of commerce, African House, Water Street, Liverpool, which is, by the way, shortly to be transferred to Colonial Chambers, now in course of being erected. In addition to the services mentioned, Messrs. Flder, Dempster \& Co. maintain a service of Mail Steamers between Antwerp and the River Congo, under the title of the Compagnie Belge Maritime du Congo, an inter-insular Mail Service at the Canary Islands, and a Coastal Service at Jamaica. They do also a large Ocean Tramp business, being prepared to carry cargo, when sufficient inducement offers, to and from any port in the world. 
It is the existence of such splendidly managed mercantile fleets, such as the Elder-Dempster Line, that enabled Great Britain to astonish the world by the rapid and safe transport of troops and munitions of war during the progress of the late War in South Africa. Many years of experience in the management of steamships have enabled the company to design and construct a magnificent fleet of fast cargo liners, having lofty 'tween decks, and fitted with anti-rolling keels, electric light and every modern improvement. Several of these were chartered at an early stage of the war by the British Admiralty, and retained for voyage after voyage as transports. Nine steamers, of an aggregate gross tonnage of 52,000 tons, were requisitioned in this way. In addition to these, the firm's steamers carried with remarkable success some 26,000 horses and 21,000 mules from New Orleans to the Cape, and some 5,000 horses and 3,000 mules from Canada, Hungary, the River Plate, \&c. It may also be mentioned in this connection that the Elder-Dempster Liner Monterey conveyed "Strathcona's Horse," the Milwaukee the "Royal Canadians," and the Montfort the Canadian contingent of Baden-Powell's Police from Halifax, N.S., to the Cape. The Mrwwaukes was the transport selected to convey General Cronje, his family, and over 500 Boer prisoners to St. Helena. The Elder-Dempster transports had the good fortune on several occasions to be able to render material assistance to other transports which had met with mishaps. Thus they came to the assistance of the Carinthia a few days after she stranded at Aux Cayes, and, taking off her cargo of mules, carried them on to their destination. The Montrose turned up just in the nick of time to save the crew when the ill-fated MExicax foundered off the Cape, and when the Suffouk stranded it was again an Elder-Dempster liner, the LAKF Lrif, that came to her assistance, and did all that was possible to rescue the crew.

In the summer of 1902 Messrs. Kilder, Dempster \& Co. commenced running the luxuriously appointed ocean liner Lake Simcoe on pleasure cruises to the Norwegian Fjords. Those persons who have had the pleasure of travelling by this vessel are most enthusiastic in their praise of the ship, her 
officers and her equipment, and of all who are responsible for the comfort and enjoyment of the passengers. The LAki Simcoe is probably one of the largest pleasure steamers trarling to the Norwegian Coast, but her rates of passage money are by no means commensurate with her size. It is an opportunity of visiting the Land of the Midnight Sun in comfort and even luxury which ought not to be missed. The fact that a large proportion of the commanders, officers, engineers, seamen and firemen serving under the firm are Royal Naval Reservists renders the Elder-Dempster fleet additionally valuable to the nation.

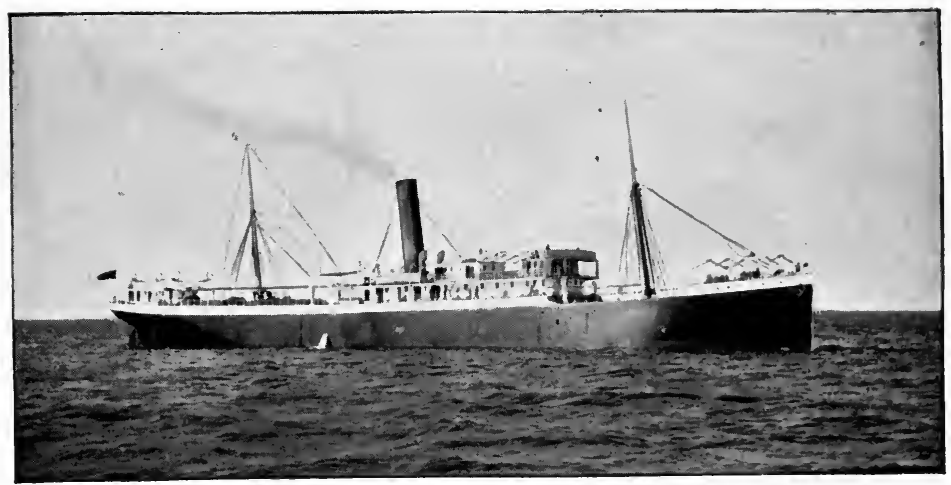




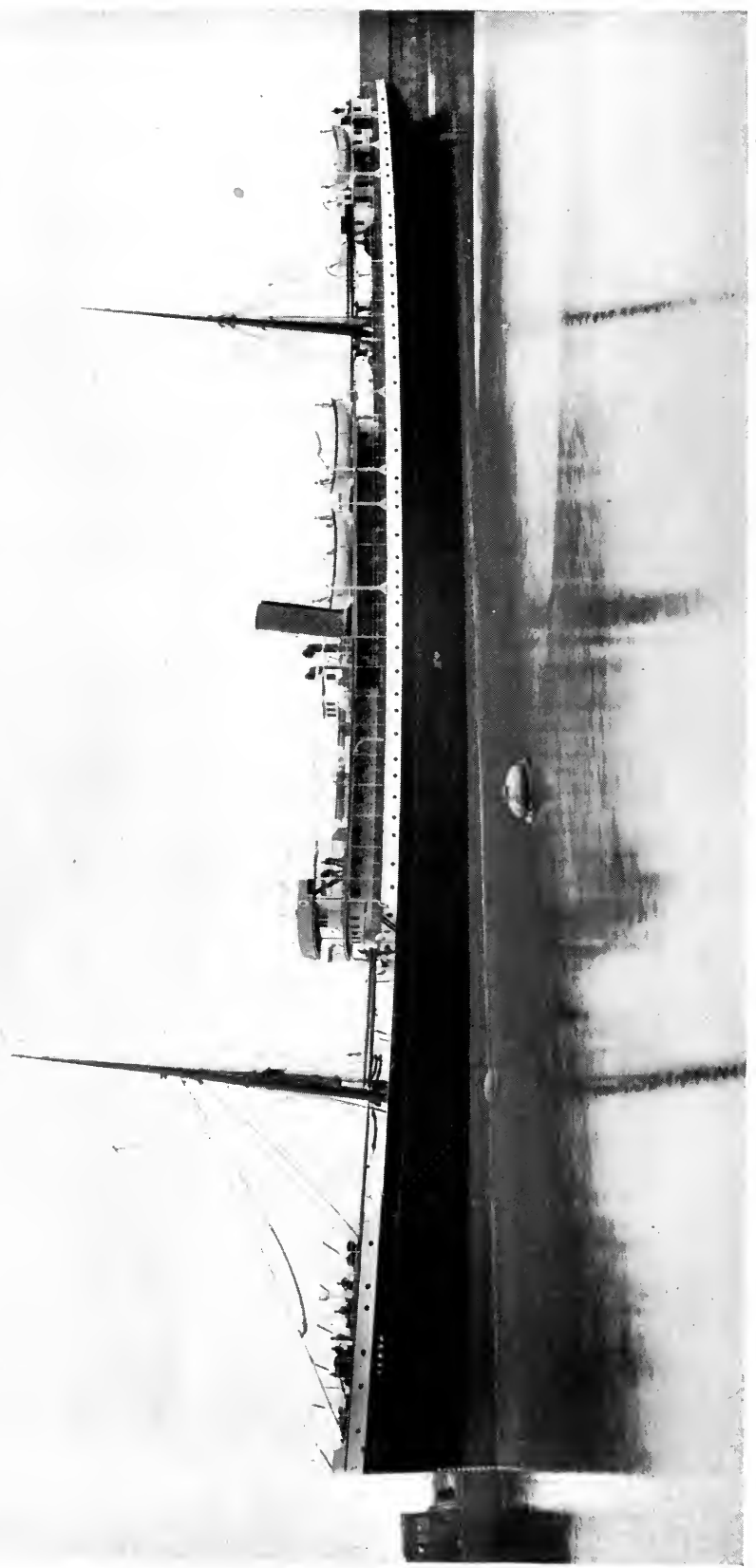

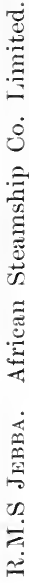




\section{Chapter II.}

\section{THE AFRICAN STEAMSHIP COMPANY.}

Two years (1852) prior to the outbreak of the Crimean War, the African Steamship Company was incorporated by Royal Charter with limited liability. The initial capital was $£ 250,000$ in 12,500 shares of $£ 20$ each. The first directors of the Company were-Sir John Campbell, K.C.H. (Chairman), James Hartley, Esq. (Director of the P. and O. Co.), John Black, Esq., Henry William Schneider, Esq., Macgregor Laird, Esq., Henry William Currie, Esq., William Law Ogilby, Esq., and Charles William Gregory, Esq. Bankers, Messrs. Currie \& Co., Cornhill.

The prospectus of the company, as published in the "Times," 13th July, 1852, was as follows:-

"This Company is formed to carry out a contract with H.M.

"Government for the monthly conveyance of the mails to

"Madeira, Teneriffe, and the principal ports and places on the

"West Coast of Africa, viz., Goree, Bathurst, Sierra Leone, " Liberia, Cape Coast Castle, Accra, Whydah, Badagny, Lagos,

"Bonny, Old Calabar, Cameroons and Fernando Po; and to " establish a line of steam communication between Sierra "Leone and the British West Indies as soon as satisfactory " arrangements are made with the Government.

"The contract for the mails was taken by Mr. Macgregor

"Laird in December last, and is for a term of ten years from "the 1st September next. The annual payment by the "Government commences at $£ 23,250$, and diminishes at the " rate of $£ 500$ yearly during the continuance of the contract, “ making an average payment of $£ 21,500$ per annum.

"Five iron screw steamships for this service are in the " course of construction by Mr. John Laird, of Birkenhead, 
"with engines by Messrs. George Forrester \& Co., and "Fawcett, Preston \& Co., of Liverpool.

" The first of these vessels is to be launched on the 3rd July, " and will be ready to commence the mail service in accordance " with the terms of the contract on the 1st September. Two " of them have capacity for 700 , two of them for 1,000 , and " one for 250 tons cargo, with excellent accommodation for "first-class passengers. The company are also to have Mr. "Laird's services as Managing Director. A negotiation is "going on with the Portuguese Government for an extension " of the line from Fernando, the valuable African possession.

" Plymouth will be the first port of arrival, and the last " port of departure for the company's vessels, but the voyage "will terminate at and commence from London."

The steamers referred to were the Forerunner, Faith, Hope, Chariti, and Northers Lights.

The trading operations between London and Africa not being profitable, the Board of J)irectors (about 1860) proposed to wind up the company.

On the solicitations of Messrs. Fletcher \& Parr, of Liverpool, they were induced to try the trade from Liverpool to the West Coast of Africa. The resuit of the trial was extremely satisfactory, and Liverpool became the home-port of the fleet. The business of the company increased rapidly, and the shareholders received their dividends for some time with gratifying regularity, but unfortunately about ten years after the change from London to Liverpool, the relations between the Board of Directors at the former port and the managing agents at Liverpool became somewhat strained.

In spite of a great financial loss, caused by the defalcations of the Secretary; of a small and inefficient fleet; and a policy on the part of the Directors which was decidedly peculiar, the company maintained a struggling existence until 1891, when it passed into the management of the firm of " Elder, Dempster and Co." Under the vigorous and successful management of this firm, the African Steamship Company started on a new and prosperous career. Instead of, as in 1875, possessing a theet of seven ocean steamers and two coast vessels, the 
company now owns thirty-three modern, large and powerful ocean steamers, ranging from 1,000 to 5,200 tons each, and six branch steamers, four of which are 1,000 tons each.

An Express Service to the Coast has been established by means of a fleet of fast steamers of the J ввв type, which reach Sekondi, the centre of the new gold mining industry, in 15 days. They have been specially constructed for the trade in which they are engaged, and no skill has been wanting nor expense spared to make them the most perfect of their kind.' The passenger accommodation has received special attention. The saloons are spacious, the staterooms lofty and well ventilated, while extensive promenade and bridge decks enable passengers to enjoy the invigorating sea breezes secure alike from sun and rain.

The company grants special facilities for visiting the beautiful islands of Madeira, Teneriffe and Grand Canary, issuing special holiday tickets, which include first-class passage out and home, and a fortnight's board and accommodation at the Hotel Metropole, Las Palmas, for $£ 15$. Passengers have also the option of returning via Barcelona or Genoa, by the steamers of "La Veloce Navigazione Italiana a Vapore" (The Italian Express Steam Navigation Co.).

The Royal Mail Steamers of the African Steamship Co., conjointly with the steamers of the British and African Steam Navigation Co., sail from Liverpool thrice a week for the Canary Islands and the West Coast, from Hamburg and Amsterdam weekly, and from Antwerp (Cie Belge Maritime du Congo) for Teneriffe, Sierra Leone and Congo Ports every third week.

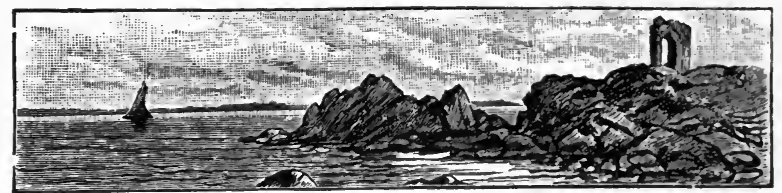




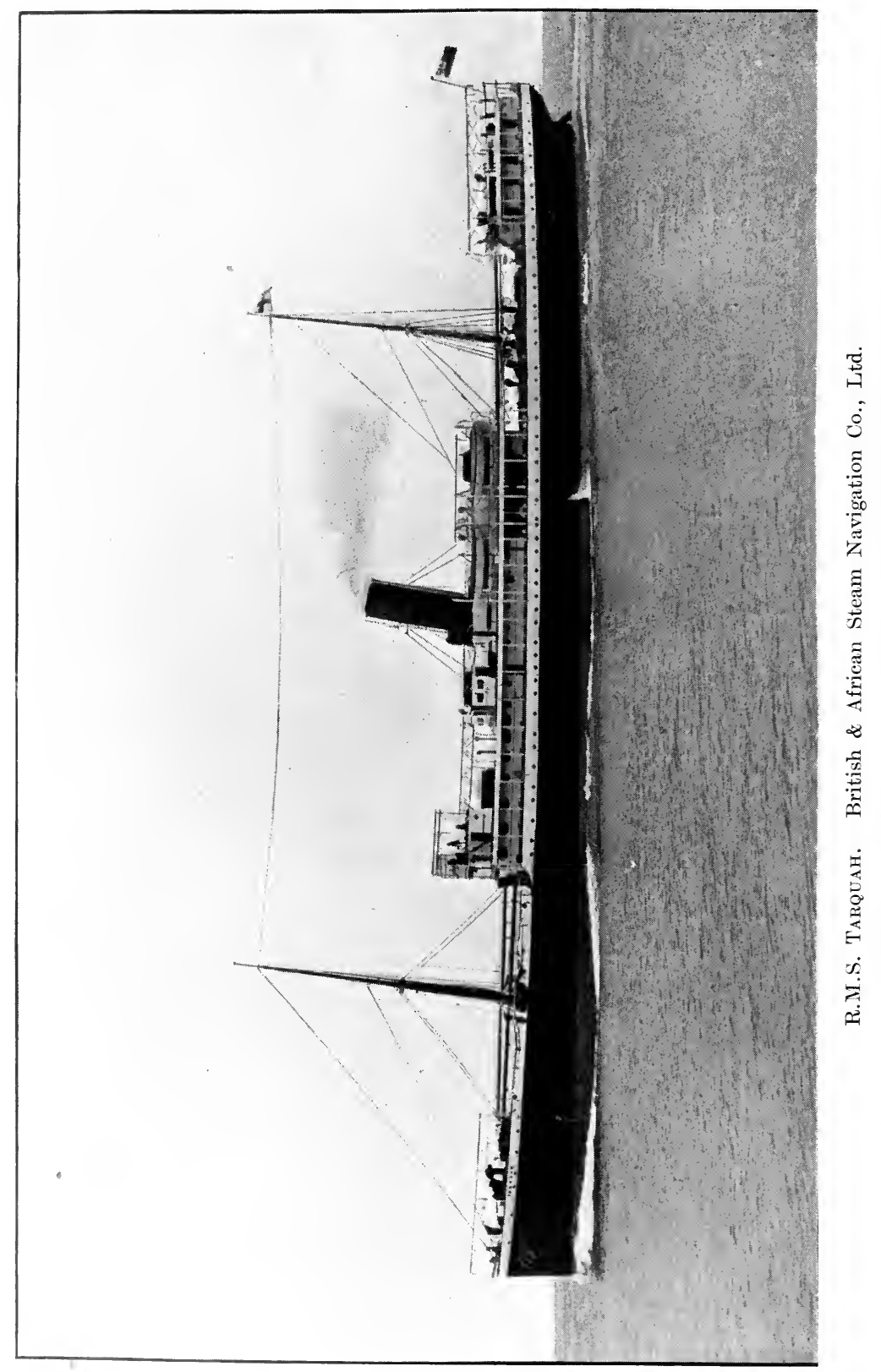


Chapter ili.

\section{THE BRITISH \& AFRICAN STEAM NAVIGATION COMPANY, LIMITED (1900).}

THIs Company was projected in 1868 by a number of gentlemen practically acquainted with the trade of the West Coast of Africa. Amongst these were Mr. Alexander Elder and Mr. John Dempster who in that year founded the firm of Elder, Dempster \& Co., a firm whose ramifications during these later years, under the guidance of Sir Alfred L. Jones, K.C.M.G., and Mr. Davey, may be said to extend throughout the civilized world.

Three steamers of about 1,300 tons gross each, were specially built to the order of the new company, by Messrs. Randolph Elder \& Co., of Glasgow, for the West African trade, and were named the Bonny, Roquelie, and Congo.

The Pioneer steamer, the Bonvy, sailed from Liverpool in January, 1869, and thereafter a monthly service was maintained between Glasgow, Liverpool and the West Coast of Africa. After several years' employment in this trade, the Roquelle was sold to Messirs. P. M. 'Tintore \& Co., Barcelona, and is still sailing from the Mersey under the Spanish flag.

So successful were these steamers that in 1869 it was decided to ádd three more to the fleet.

The new steamers were the Liberia, Loanda and Volita, also specially built for the trade by the late Mr. John Elder, the distinguished brother of Mr. Alexander Elder, whose early death towards the end of 1869 was so much deplored by the ship-building and engineering world. The gross tonnage of these three vessels was increased to about 1,500 tons each.

It was considered desirable during the same year to register 
the Company as an Incorporated Company. The Registered Office of the Company was in Glasgow, but Mr. Alexander Elder and $\mathrm{Mr}$. John Dempster conducted its operations in Liverpool.

With the six steamers the Company now possessed the sailings were increased to fortnightly.

In $18 \pi t$ the sailings from Glasgow were abandoned, eargo to and from that port being transhipped at Liverpool.

As the trade expanded, additions were regularly made to the fleet, and in 1879 sailings between Hamburg and the West Coast of Africa were commenced. In 1883 the Company was registered as a limited company, at which time its fleet had increased to 20 steamers and 2 hulks with a gross registered tonnage of 30,753 tons.

The following year (1884) Mr. Elder and Mr. Dempster retired from the firm of Elder, Dempster \& Co., which since 1879 had consisted of these gentlemen and Mr. (now Sir A. L.) Jones, and Mr. W. J. Davey. Messrs. Elder and Dempster, however, remained Managing Directors of the Company until 1900, Mr. Elder having for some years previous to this date occupied the position of Chairman.

In 1900 Messrs. Elder, Dempster \& Co., purchased the entire business and assets of the British and African Steam Navigation Co., Limited, and with the addition of 9 large steamers, suitable for outside trades, formed a new company with a share capital of $£ 1,000,000$, and Debenture Stock of $£ 800,000$. The new company has a fleet of 35 steamers with a total gross registered tonnage of 107,000 tons.

While the bulk of its operations continue to be in connection with the West Coast of Africa, several of its steamers are employed in the North Atlantic and other trades.

The contrast between the first steamer, the Borvy, and the latest, the Burutu, built in 1902, will be seen by the following comparison of their respective dimensions:-

Bonny, length $261^{\circ} 0$ feet, beam $30 \cdot 2$ feet, depth 23 feet. Gross 1,326 tons.

Burutu, length $360 \cdot 0$ feet, beam $44 \cdot 2$ feet, depth 26 feet. Gross 5,200 tons. 
In the later steamers of the fleet, the vessels of the Burutis type, traders and other travellers reach Sekondi, the centre of the new gold mining industry, in about 1:3 days from Liverpool. No skill has been wanting nor expense spared to make these vessels the most perfect of their kind, and exactly suitable for tropical trade.

A special feature of the steamers is the system of overhead trunk ventilation, by which an imperceptible current of fresh air is kept continually circulating through the lofty and well lighted state rooms, making them cool and agreeable in the hottest weather.

Passengers by the Royal Mail Steamers belonging to the British and African Company, are granted special facilities for visiting the beautiful islands of Madeira, Teneriffe and Grand Canary. The Company issues a special holiday ticket for $\mathfrak{£ 1 5}$, which includes Saloon passage out and home, and a fortnight's board and accommodation at the Hotel Metropole, Las Palmas. Passengers by these steamers who may wish to visit the Mediterranean, have also the option of returning from the islands via Barcelona or Genoa, by the steamers of the Italian Express Steam Navigation Co.

The Royal Mail Steamers of the British and African Steam Navigation Co., conjointly with the steamers of the African Steam Ship Co., sail from Liverpool three times a week for the Canary Islands and the West Coast of Africa, and from Hamburg and Rotterdam weekìy.

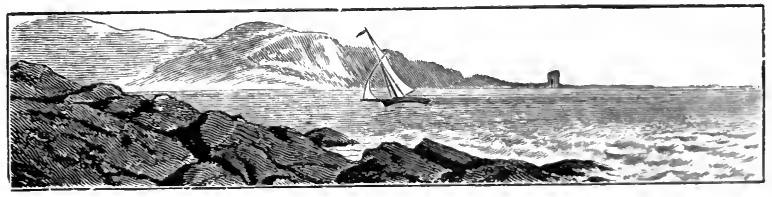




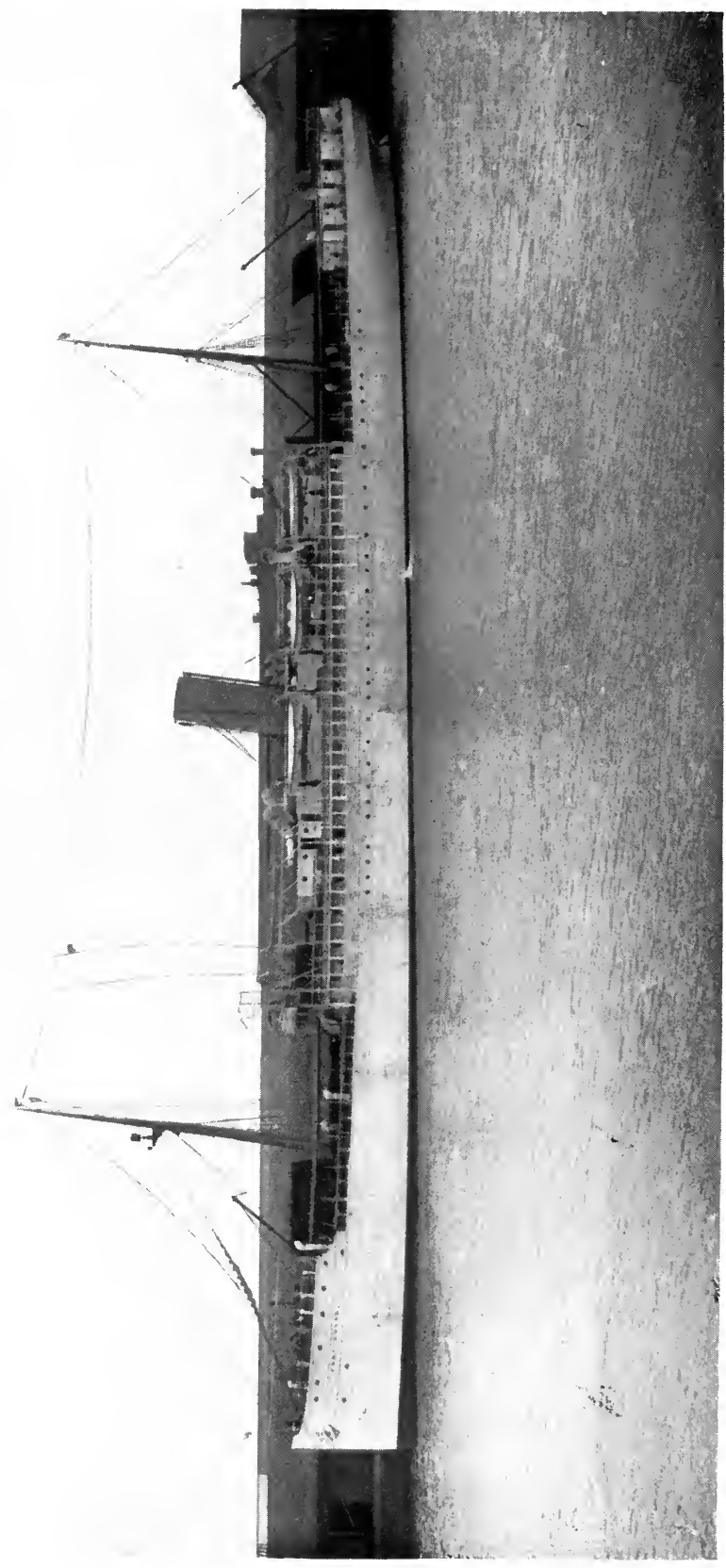

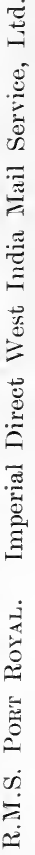


Chapter IV.

\section{IMPERIAL DIRECT WEST INDIA MAIL SERVICE, LIMITED.}

For years the Island of Jamaica, the Pearl of the Antilles, had been decadent, its planters cast down and despairing because it was impossible, owing to the heavily subsidized continental beet sugar, to grow cane sugar at a profit. And, although physicians in the United States were sending their patients to seek renewed health and energy "from the balmy breezes laden with health giving ozone which blow over the island," British Life Insurance offices placed a black mark against Jamaica, and demanded an additional premium from their policy holders for permission to visit its shores. But the dark commercial cloud is passing, and the island has entered upon an era of prosperity which bids fair to be greater and more permanent than even the golden days of the sugar planter. It is an open secret that for this the Jamaicans are indebted in great measure to the enterprise of Messrs. Elder, Dempster and Co., who have practically created the demand in Great Britain for Jamaica grown fruits, and who have established a service of swift steamers, specially built for the trade. This Line of steamers, which is known as the Imperial Direct West India Mail Service although only established in the first year of the present century, has already achieved a remarkable success. In addition to bringing to England over 50,000 bunches of bananas per month, as well as other West Indian fruits, tobacco, coffee, sugar, rum, and other varieties of tropical produce, the steamers carry a large and increasing number of passengers each voyage between Great Britain and the colony. 
The home port of the steamers is Avonmouth, near Bristol, from which a fortnightly sailing is maintained throughout the year to Kingston (Jamaica), but it is probable that the service will soon be increased to a weekly one. In recognition of the invaluable services rendered by these steamers both to the Empire and to the colony, their Royal Highnesses the Prince and Princess of Wales paid a visit of inspection to the R.M.S. Port Royal, at Avonmouth, on the 5th March, 1902.

The vessels at present engaged in the direct Mail Service were all built in 1901, and are named, the Port Royal, Port Axtonio, Pont Moraxt, and Port Maria. The first two steamers named are sister ships and are identical in measurement, viz., length 382 feet, beam 46 feet 6 inches, and depth 32 feet. Each is propelled by twin screws, and fitted with triple expansion engines capable of maintaining a speed of 14 knots per hour, and carries about 5,000 tons cargo. They can each accommodate 100 first-class passengers and 50 secondclass passengers. The saloons and staterooms are handsomely decorated, and are fitted so as to secure a maximum of comfort for the passengers. The cuisine and the appointments generally being those appertaining to a first-class mail and passenger steamer.

A new mail steamer of considerably larger dimensions than any of the preceding steamers of the fleet, is now in course of construction and is expected to make her first voyage early in 1904. It is proposed to call her the Port Kingston.

These steamers sail from Avonmouth Dock, Bristol, every alternate Saturday, and make the voyage as a rule in from 12 to 14 days. The rates for passengers are:-Saloon (single) $£ 18$ to $£ 25$ pounds; (return) $£ 32$ to $£ 40$, according to the position of the state-room, and number of persons occupying same. In the second saloon the charge is $£ 1+$ for the single passage, and £25 for the return.

The Desta, belonging to the same Company, makes a trip round Jamaica every week; she has first-class accommodation for passengers, and affords a splendid opportunity of seeing the coast and towns around the Island. The charge for firstclass passengers is $£ ?$ for the round trip. 
Arrangements have been made with the Hamburg-American Line, running between Kingston (Jamaica) and Central American' Ports, to carry passengers booked by Imperial Direct West India Line of Steamers to the following C'entral American Ports, viz., Savanilla, Cartagena, Port Limon, and Greytown, at an inclusive first-class fare between Kingston and any of the above Ports of $£ 6$ 3s. per adult. Passengers travelling on these tickets will be accommodated on special terms at the Myrtle Bank Hotel (Kingston), during the time between the arrival of the Mail Steamers and the departure of the Steamer of the Hamburg-American Line. There is also a good service from Kingston to Cuba. The Cuba steamer leaves Kingston the day after the arrival of the mail steamer from England.

Passengers can also be booked through, via the Colon and Panama Railway, to the principal ports on the Chilian Coast. The steamers of the Pacific Mail Co. and Campania SudAmericana Co. leave Panama weekly for the South, reaching Callao in about nine days and arriving at Valparaiso in about 21 days. Seeing that for years past the elimate of Jamaica has been libelled as unhealthy, it cannot be too strongly affirmed, that from a medical point of view, the wonderful air of the hilly districts is unrivalled; it being in every way equal to that of the better known European winter resorts, to which it bids fair to become a serious rival.

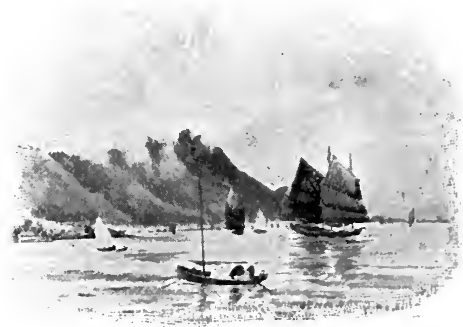




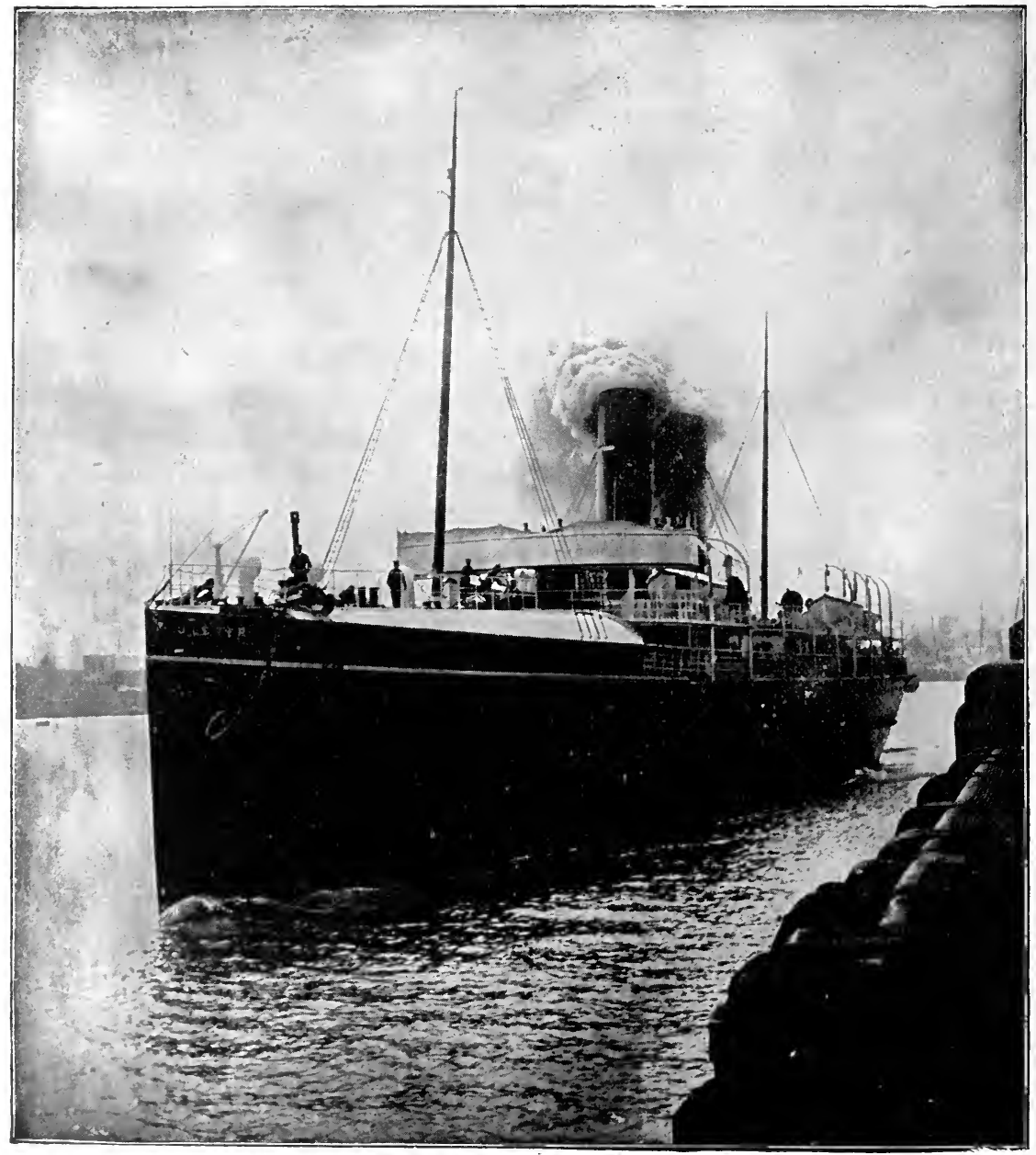

R.MI.S. Ulster, City of Dublin Steampacket Co. 
Chapter $V$.

\section{THE CITY OF DUBLIN STEAMPACKET COMPANY.}

In the summer of the year 1822 Mr. C. W. Williams, of Dublin, crossed over to Liverpool with the object of inducing the merchants to take shares in a line of steampackets he proposed building for the Liverpool and Dublin trade. Except to the most sanguine, the time did not appear to be favourable for such a scheme. A large fleet of sailing smacks maintained daily communication (subject to the weather) between the two ports, carrying all kinds of goods, and even cattle. The steampackets Waterloo and BELFast sailed with passengers only every alternate day from each side. Both these vessels had already won for themselves a reputation, the former being the first steampacket to ply regularly between England and Ireland, and the latter having made a passage in the then remarkably short time of $12 \frac{1}{2}$ hours. Besides this, "The Original Steampacket Company," a new company (with powerful Government influence), including amongst its shareholders Lord Blaney, Major-General Preeth, Sir John Tobin, \&c., and trading under the title of the St. George Steampacket Company, had in April preceding launched two of the largest and most powerful steampackets that had yet been built, viz., the St. Patrick and the St. George. This latter vessel on the 13th September made a passage from Dublin in $11 \frac{1}{2}$ hours, thus making a record which she herself broke on the 23rd April, 1824, by making a passage from Liverpool to Dublin in 10 hor:rs 40 minutes. In addition to the already established steam and sailing lines, a third local steampacket company, supported by the traders, the "Dublin and Liverpool Steam Navigation Company," was in course of formation. It is not, 
therefore, surprising under these circumstances that Mr. Williams, a stranger in Liverpool, failed to obtain the financial support to his scheme which he desired. It is the more to his credit that, though disappointed in Liverpool, he persevered with his project in Dublin with so much success that he was enabled to return to Liverpool in February of the following year (1823) and place an order with "Frigate" Wilson for the pioneer steamer of the future famous City of Dublin Steampacket Company, the City of Deblix, a vessel of 130 h.p. It was an express stipulation with the builder that this steamer should be constructed of such materials and in such a manner as to withstand the severity of the winter navigation. The City of Dublis differed from her competitors in two respects--(1) in carrying general cargo in addition to live stock and passengers, and (2) in maintaining the service uninterruptedly throughout the twelve months.

A month later Mr. Wilson was again applied to to build a second vessel for the company, but in consequence of his having that very morning (5th March) contracted to build the Hy. Bell for the Glasgow trade, it was not till some days later the contract was made for the building of the Tows of Liverpool, to be commenced as soon as the Hy. Bell was launched.

The City of Dublin made her maiden voyage on Saturday, the 20th March, 1824, and Mr. Samuel Perry, of 16, Water Street, was appointed agent to the company. She anticipated by about six months the operations of the traders' company (the Dublin and Liverpool Steam Navigation), whose first steamer, the Liffex, 305 tons burden, and 110 h.p., did not sail until the 13th September following. From the outset the managers of the City of Dublin Company seemingly did not regard the Original Steampacket Company as formidable opponents, but they determined either to vanquish or acquire the other two companies, the greater of which was the St. George Steampacket Company. The second company was well supported by the Liverpool merchants, and kept its sailings (with goods and passengers) throughout the year. In December of the same year (1824) the Mersey joined the Liffey, and in 
the July following the Commerce, one of the largest steampackets (up to that date) built in this port, was added to the fleet. This company's packets proceeded direct to Dublin, and discharged at Custom House Quay. On Saturday, 5th February, 1825, the third vessel belonging to the City of Dublin Steampacket Company was launched from the yard of Dawson and Pearson, South Shore, and on the 22nd April succeeding the managers issued the following public notice:-

"The City of Dublin Steampacket Company announce to the "public that in consequence of the many complaints hitherto "made of want of storage room in Dublin for "goods going and coming by their steam vessels, they "have taken the lot of ground immediately opposite the "Packet Station on the North Wall, and are about to erect a " convenient and commodious store on the same for the accom"modation of the merchants and traders of Dublin. The "Company have increased their capital to $£ 100,000$, and are "proceeding with every possible expedition in completing " their number of vessels, by which means they will shortly be "able to despatch one daily from Dublin and another from "Liverpool. The trustees have reserved the remainder of the "shares now unappropriated exclusively for the accommoda"tion of shippers and importers. Their vessels, the Citr of "Dublin and Town of Liverpool, continue to ply as usual. "Their third and fourth vessels, the Hibersia and Britaxyia, "are nearly complete, and the fifth and sixth will be ready by " the end of the year."

During the summer of 1825 the City of Dublin Company despatcher? their new steamer Hibersia on the same day and at the same hour as the ST. George. They were careful to inform those interested that this was done " not with a view "of opposition, but for the purpose of establishing her (the "Hibernia's) character for speed and seaworthiness." They were equally careful to point out that "the Hibersia has "already made six voyages in company with the ST. GEorge, " and has on all occasions proved herself an extremely safe "and fleet vessel, and not inferior to that well-known "steampacket." They also mentioned the incouvenience, 
delay and expense of landing by boats at Kingstown, all of which might be avoided by taking their magnificent steampackets direct to North Wall.

The St. George Company replied to this courteous announcement by also informing the public that the companionship of the Hibernia was unsought for and undesired by them. It was not to be expected that the Liverpool companies would permit a strange company to take a lion's share of the trade, and not make a practical protest. Consequently, in the autumn of 1825, the fares from Liverpool to Dublin were reduced to $5 \mathrm{~s}$. cabin and 6d. steerage, and on Monday, September 5th, one of the steamers sailed with upwards of 700 passengers at 6d. each. Early the following year (1st February, 1826) the managers of the City of Dublin Steampacket Company purchased the Dublin and Liverpool Steam Navigation Company, and increased the capital of the company to $£ 250,000$, in shares of $£ 100$ each. Shareholders, in addition to their share of the profits of the undertaking, were offered the following advantages:-

(1) Free passage by all the company's vessels.

(2) Free storage for a limited time in the company's stores.

(3) Special accommodation in the payment of freights and charges.

The company having grown with a rapidity probably without a parallel, decided to extend its sailings to Belfast and Waterford, and, if desirable, to other ports. It had now a fleet (afloat or building) of fourteen new and powerful steamers, viz., City of Dublin, Town of Liverpool, Hibernia, Britannia, Liffey, Mersey, Commerce, Mona, Leeds, Gipsey, Manciestrer, Birmingham, Sheffield and Nottingham. On the 29th August, 1826, the Government established a mail service between Liverpool and Kingstown, with most injurious results to the existing steampacket companies. The managers of the City of Dublin Company interviewed the Secretary to the General Post Office in order to obtain some modification of the opposition, but without being able to do so. They thereupon published the result of their negotiations, and appealed to the public for support against the unjustifiable 
aetion shown by the Government. "The Post Office having " now established packets on the station, have, with a view of " covering the heavy expenses incilent to the same, " endeavoured to engross the trade in passengers, carriages, "horses, \&e., to the great injury of this and other companies; "while at the same time they are exempt from the payment " of port dues and other charges . . . . which are already a " tax on this company to the amount of $£ 10,000$ per annum. "Under terms so unequal and disadvantageous, it is evident "this opposition has none of the ingredients of fair opposition, "were such even justifiable, where Government on the one "hand, and private shipowners on the other, are the "competitors."

At this period (1827) there was considerable friction between the Mersey Doek Board and the company, the managers of the latter considering greater facilities ought to be given for the working of their traffic in view of the fact that they annually spent in Liverpool $£ 100,000$ in outfits and repairs. To meet the Government opposition the company purchased the sailing brig True, which they loaded fortnightly with rough goods, and towed to sea by their own tug Mars. In 1828, in addition to their daily service to Dublin, the company had a twiceweekly service to Belfast, and once a week to Drogheda. A fortnightly service between Dublin and Bordeaux was commenced on the 20th June, 1827. The Ballinaslok, built in 1829 , was furnished with a powerful blast cylinder to rentilate the holds, being the first steamer to be so fitted. The same year the Manciester and the Britanxia were both wrecked, but fortunately without loss of life.

The steampacket CiTr of Londonderry, built in 1827 for a local company, was sold by auction on the Sth October, 1829, and purchased by the City of Dublin Company. Her new owners took up the station vacated by the Derry Company, and maintained a weekly service between Liverpool and Londonderry for a number of years. The Clarence Dock having been opened in September, 1830, the City of Dublin Company were allotted loading and diseharging berths in it on the 25th Mareh, 1831, which berths they have used continuously to the 
present date (1903), a period of over seventy years, when they were transferred to the Nelson Dock.

It will be remembered that in the early history of the company their most powerful trade competitors were the St. George Steampacket Company. One of the steamers of the latter company (the Lord BLANex), while on a voyage from Liverpool to Newry, was lost with all hands. With a chivalry unusual in commerce (ignoring the fact that the vessel belonged to a rival company) the City of Dublin Company headed a list for the benefit of the relatives of the drowned seamen and others with a subscription of one hundred pounds. Civil war had been raging in Portugal for a number of years, the leaders being Don Miguel (the usurper) and Dom Pedro, on behalf of his daughter, Donna Maria (Legitimist). Two at least of the company's steamers, the LeEDs and Birmingham, were chartered as transports to Dom Pedro; and it was the latter vessel, under the command of Captain Beazley, which, on the 16th July, 1833, brought to England the news of the complete defeat and capture of the fleet of Don Miguel. On the 6th November, 1834, the LeEDs struck on Furlong Rock. No lives were lost, the crew and passengers being taken off by the company's steamer Commerce. The LEEDs having got off the rock, sank inside the jetty at Holyhead, but was subsequently raised.

In 1836 the company built four steamers to compete against the Government mail steamers. They were the Quess Victoria, Duchess of Kent, Royal Adelaide, and the famous Royal William. In June of this year (1836) a bill in Parliament for increasing the capital of the company was read three times and passed.

About this time the directors of the company had under consideration the establishing of steam communication between Liverpool and New York. A meeting was held in the company's office in Water Street, there being present, amongst others, Sir John Tobin. Sir John had on the stocks a large steamer, and it was decided that the Transatlantic service should be established, the pionèer vessel to be the Royal William, to be followed by the Liverpool (Sir John Tobin's 


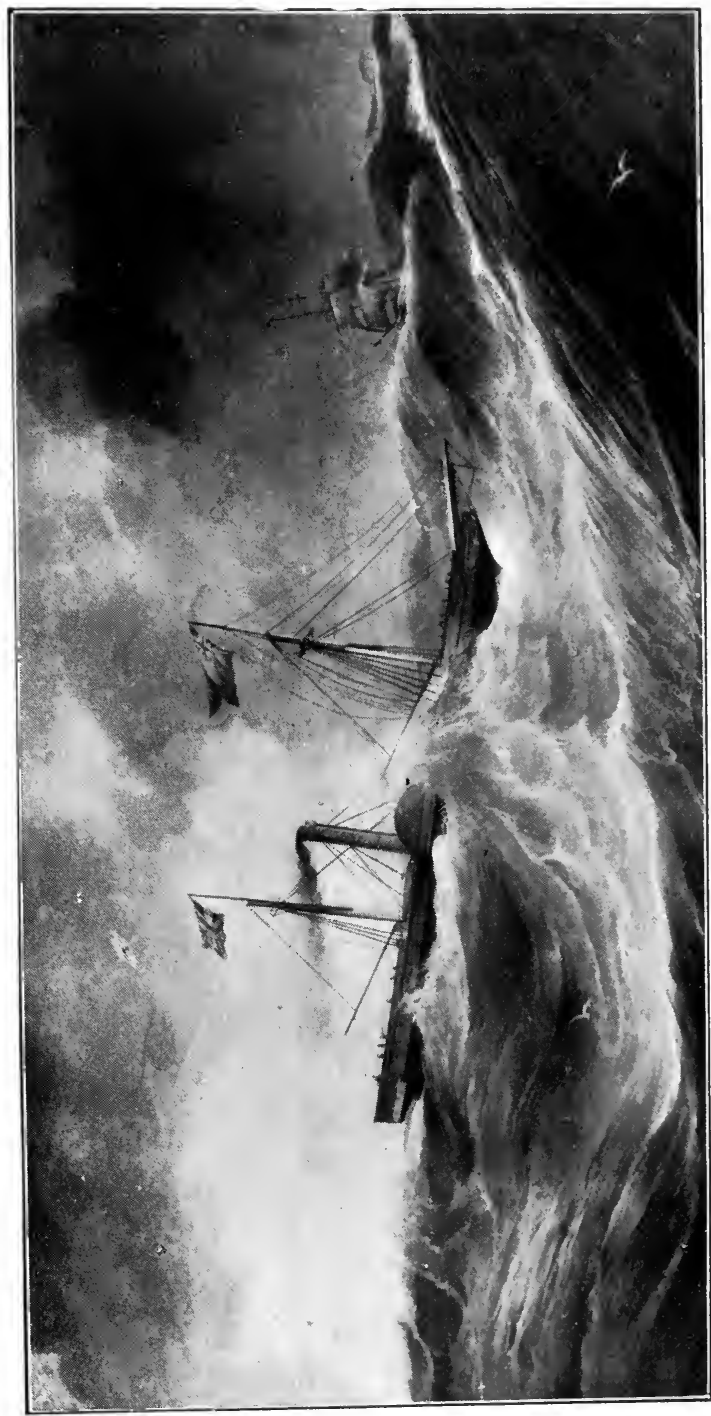

ن 
new steamer) as soon as she was ready for the service. In accordance with these arrangements, the Royal William sailed from the George's Pierhead on July 5th, 1838, for New York, and the Liverpool followed her on September 20th. These steamers have the honour of being the first passenger liners between Liverpool and New York. The Royal William proved to be too small for the Transatlantic trade, and in 1839 she resumed her sailings on the Liverpool and Kingstown station.

On and from the 20th June, 1839, the Government determined that a mail steamer should be despatched every morning and evening from Liverpool to Dublin, via Kingstown, on the arrival of the respective mail trains from London. The Government steam packets were appointed to sail with the morning mails, and the City of Dublin steam packets with the evening mails. The directors of the City of Dublin Company were determined that their steamers should surpass the Government boats, and in December, 1840, they contracted for two new steamers for the mail service to be superior to any seagoing steamers afloat, and to do the passage from Liverpool to Kingstown in nine hours. Three years later (15th April, 1843) the company commenced their Liverpool and North Wales service with the new iron steamer ERIN-Go-Bragir. The steamer Ayrshire Lassie was placed on the station the next season (May, 1844), followed in 1845 by the Prince or Wales, and later by the Prince Arthur, which two steamers maintained a daily service throughout the summer season for many years, and until the station was transferred to the present North Wales Steampacket Company.

In conjunction with the North Lancashire Railways, the City of Dublin Company instituted, in 1844, a steamship service between Dublin and Fleetwood, the first steamer employed being the Hibersia. 'The Company's trade between England and Ireland had increased so rapidly that in 1845 the directors placed orders to build eight vessels, viz., five paddle steamers and three auxiliary screw schooners.

The long contest between the Admiralty and the company for the carriage of the English and Irish mails came to an 


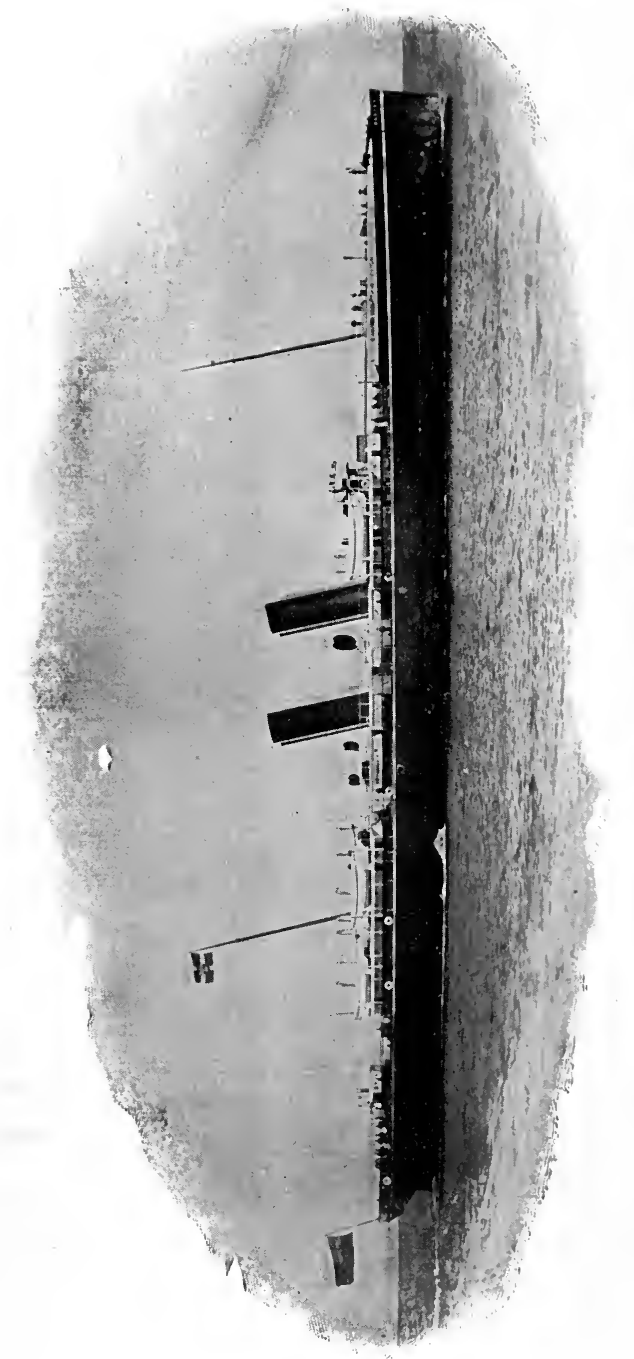

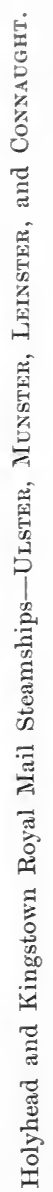


end in 1850, when the Lords of the Admiralty determined to withdraw their steamers from the Irish mail service. The City of Dublin Co. had now a new competitor in the Chester and Holyhead Railway Company, who had steamers in connection with their railway service. The former company, who recognised the great importance of placing vessels on the Holyhead station, put in a tender in response to the Admiralty's invitation, which tender was actually accepted. No tender was put in by the Chester and Holyhead Railway Company, who, it was believed, did not suppose anyone would compete with them and that they could obtain their own terms. Before the Admiralty's acceptance of the City of Dublin Company's tender was confirmed by the Goverument the railway company got notice of what was being arranged, and pressure was brought to bear upon the Government to prevent the City of Dublin Company's contract from being ratified. The move was successful, with the result that tenders were again asked for. The City of Dublin Company were most unfairly treated, for the figure at which they had tendered was made public, and consequently the railway company were able to under-cut it. In anticipation of this course being adopted the managing director of the City of Dublin Company recommended a tender to be put in at a very diminished figure, the great importance of securing a footing on the Holyhead station being fully perceived by him. The City of Dublin tendered at $£ 25,000$ per annum, which was $£ 5,000$ a year less than the Chester and Holyhead Railway Company's offer, and the result was that the City of Dublin Company obtained the contract. They purchased from the Admiralty two of the mail boats, the ST. Columba and the Llewellyn, and in May, 1850, took over the mail service, rumning the steamers at the same hours as they were run by the Admiralty. A strong effort was made by the opponents of the company to deprive them of their contract, and a select Parliamentary Committee was appointed, which reported in favour of what had been arranged. This report made it clear that the company's first offer was a reasonable one, and subsequent events proved the wisdom of the company's directors determining to hold the contract at all hazards. The 
contest, it will be seen, was between the City of Iublin Company and the Chester and Holyhead Railway Company rather than with the Lords of the Admiralty-indeed, so strong was the feeling some time afterwards that the railway company refused to book passengers by the mail steamers, or advertise their sailings in the railway time tables, which only showed the sailings of the railway company's steamers.

But if the City of Dublin Company was thus happily relieved from rivalry on the Holyhead mail station, it speedily found itself involved in the most serious struggle which probably ever occurred in the steamship coasting trade. Yielding to the solicitations of the Waterford and Kilkenny Railway Company, the directors of the City of Dublin Company agreed to place a steamer on the Liverpool and Waterford station. The Waterford Company and the Cork Company immediately began a daily service to and from Liverpool and Dublin, and despatched a steamer twice a week to Belfast. Entering into an alliance with the British and Irish Steampacket Co., the City of Dublin Company and its ally responded by opposing the Cork Company on the Liverpool and Cork station, sailing the Duchess of Kent, Emerald, Rose, \&c., every Tuesday and Friday from Liverpool and from Cork. After a keen contest, lasting over twelve months, a conference took place between Mr. Malcomson, representing the Waterford and Cork Steamship Companies, and one of the directors of the City of Dublin Company. No reference was made at this conference as to the cause of the contest, nor to the conduct of any of the parties during its continuance, the sole object being to suggest the most speedy mode of restoring peace, and the following arrangement was finally decided upon:-The City of IJublin Steampacket Company agreed to sell their claims on the London line to the British and Irish Steampacket Company, this line to be worked by the vessels of the latter company and of Messrs. Malcomson; the City of Dublin to transfer their Liverpool and Belfast service to the Cork Steamship Company; the entire sea traffic between Holyhead and Dublin to be assigned to the City of Dublin Company. This agreement has been honourably adhered to by all the companies concerned, amongst whom a 
most friendly feeling exists, but time has wrought its changes on the various lines. Malcomson's steamers have long since ceased to run between Dublin and London, the Cork Company's steamers were withdrawn in 1854 from the Liverpool and Belfast service, and the London and North Western Railway Company have a large fleet of passenger and cargo steamers plying daily between Dublin and Holyhead.

At the close of the year 1854 a better feeling prevailed, and the Chester and Holyhead Railway Company, together with the London and North Western Railway Company, entered into negotiations with the (ity of Dublin Company, and, with the approval of the Government, an Act of Parliament was obtained in order to bring about an improved passenger and mail service between London and Dublin, via Holyhead and Kingstown. Considerable delay took place in the subsequent negotiations. However, at the end of 1858 matters were settled, and in January of the following year the PostmasterGeneral entered into a contract with the two railway companies and the City of Dublin Steampacket Company, who jointly undertook the sea service, and with the two railway companies, who undertook the land transit. By private agreement, however, with the railway companies, the City of Dublin Company became solely responsible for the sea service, and provided the four steamers. This service gave the greatest satisfaction to the travelling public; the contract was for fourteen years certain, and then from year to year, terminable by twelve months' notice, the subsidy being $£ 85,900$ per annum for the sea service, and $£ 50,000$ per annum for the land.

Twelve years after this service had been commenced, the London and North Western Railway Company, who had by that time absorbed the Chester and Holyhead Railway, commenced a rail connection between the harbour of Dublin and three of the principal Irish railway companies, which connection was completed in 1876, and the London and North Western Company began to run a service of steamers in direct opposition to the mail route. Under the terms of their agreement with the City of Dublin Company, the railway company had the power of fixing the fares by the mail route; which it 
exercised by maintaining the high fares by the mail and charging low fares by the railway steamers. The competition increased in intensity every year, with the result of largely diverting the passenger traffic from the mail route, the ultimate object of the railway being to bring about the abandonment of the Kingstown service, and to secure all the traffic for the railway boats to Dublin. In 1881 the City of Dublin Company brought the London and North Western Railway Company before the Railway Commissioners, who ordered a reduction of the mail fares. Immediately after this order was made, the Post Office authorities intimated their intention of terminating the existing mail contract, and of asking for fresh tenders for the service between Holyhead and Kingstown. In 1882 the City of Dublin Company put in a tender. Months were allowed to pass, and in January, 1883, it was announced that the Government had accepted a tender of the London and North Western Railway Company. It then transpired that the railway company, as well as the City of Dublin Company, had tendered for the Holyhead and Kingstown service, and that the latter company's tender was the lower of the two, but the Government, instead of accepting it, had negotiated a contract for the throughout service with the railway company, which would have enabled them to convey the mails and passengers in the railway steamers to Dublin instead of to Kingstown.

It can well be understood that the public, who were well pleased to have the two lines of steamers, had no intention of being deprived of the Kingstown route, and a storm of indignation arose over the country. The Government professed that in making the new arrangement they were acting with economy, but this was shown to be a mere subterfuge, for they had agreed to pay the railway company $£ 106,000$ a year-only a trifling amount less than they would have paid if the steampacket company's offer had been accepted and the railway payment continued as before. To quote the words of a prominent member of Parliament: "The Government were giving an opulent railway company not only a monopoly of the passenger traffie, but a large subsidy besides, for merely carrying 
the mail bags on their established line of passenger steamers." So powerful was the agitation that arose, that the Government discovered they would not be able to get the contract confirmed by the Ilouse of Commons, the Irish members to a man being determined to vote against it. The result was the contract was not brought forward for confirmation, and new tenders were asked for the Holyhead and Kingstown sea service, special provision

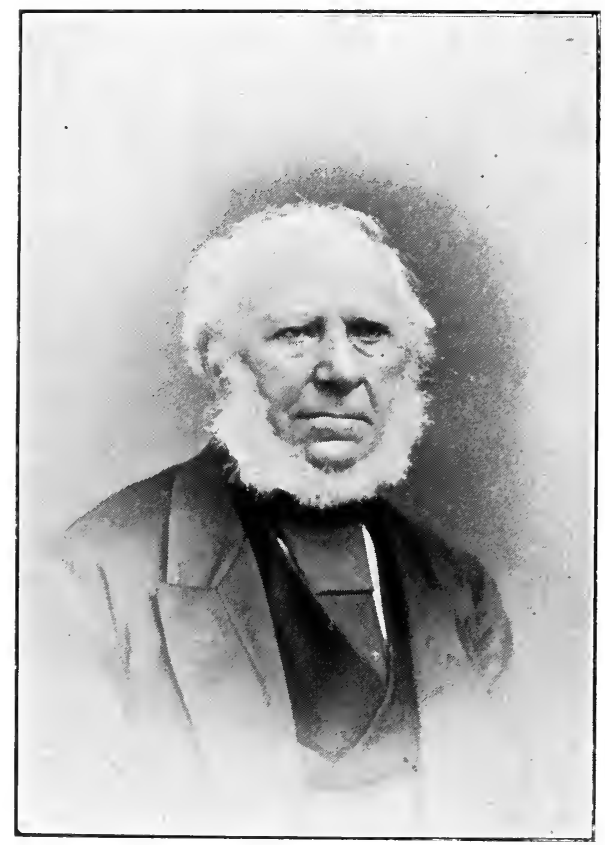

Willian Watson, Esq. (late Chairman City of Dublin Steampacket Co.).

being made for the passenger traffic, which the Government had ignored on the previous occasion. Greater speed being desired, the City of Dublin Company tendered for improved steamers; but the railway company, who had no intention of going to Kingstown, did not compete, and the City of Dublin Company were successful in obtaining a contract for twelve years certain, the subsidy being $£ 84,000$ per annum. The four 
mail packets-the Uister, Lemstrer, Mrester, and ('oxsACGHT-were provided with new boilers and improved machinery, and their passenger accommodation was remodelled and greatly enlarged.

The new service began on the 1st October, 1885, with this most remarkable result, that vessels after twenty-five years' service had their speed increased by an average of ' $2 \frac{1}{2}$ knots per hour. A new steamer was added to the fleet- the IrFiand, a vessel capable of steaming 20 knots an hour, being the fastest paddle steamer ever built for cross-Channel service. The new service gave much satisfaction to the public, and the passenger receipts steadily increased. In 189:3 the company decided to build a new type of passenger and cargo vessel, and in the following year the Louru, a screw steamer of large tonnage and great power, was put on the station; she was found so satisfactory, her performance being so regular, and her sea-worthy qualities so good, that she dispelled the great prejudice which up to that time had existed against screw steamers for crossChannel trade (especially the cattle trade), and the company decided to replace their fleet with steamers of this class. While this re-construction was going on an attempt was made to deprive the company of their position on the Holyhead station. Owing largely to the eftorts of the company, Kingstown had been put in direct communcation with ali the Irish railway companies, and the one blot on the Kingstown service removed. It was stated, however, that the boats were not fast enough, and the Government were urged to terminate the mail contract and seek for new tenders.

Most extravagant ideas seemed to prevail as to what could be done; accelerations were suggested by land and sea which could not have been accomplished except at very great expense. However, the City of Dublin Company were not behindhand, and they put in a variety of tenders, and offered to build boats of the very largest class. No other company tendered in accordance with the advertisement. The Post Office, howerer, did not accept any of the tenders, and subsequently entered into negotiations with the company, and settled the existing contract. The company undertook to build four twin-screw 
steamers, which, although not so large as those originally proposed, are superior to anything up to the present time attempted for cross-Channel purposes, and being twin-screws. their accommodation is far greater than had they been paddle steamers of the same size. They all realised a speed of 24 knots on their trial trips, which up to the present time has not been surpassed by any passenger steamer.

The new service commenced on the 1st April, 1897, and passengers are conveyed between all parts of England and Ireland at a very high rate of speed, and perform the journey with a degree of comfort that would have been thought incredible a few years since.

The fleet of the company now consists of the following highclass powerful screw steamers, replete with everything necessary for the comfort of passengers, as well as being equipped with the most modern appliances for the safe carriage of cattle and the rapid handling of cargo:-The ULSTER, Munster, Leinster, and Connaught, sailing twice each day from Holyhead and from Kingstown with the mails and passengers. The Carlow, Kerry, Wicklow, Louth, and Cork, sailing every evening to and from Liverpool and Dublin, with goods and passengers, as well as a morning service from both ports, with passengers and fast traffic. In the present year (1903) the Company has placed the Kilisenvy on the station, a vessel of an entirely new design, one of the finest passenger and cargo steamers which has ever been built for the Irish crossChannel trade. A service is also maintained three times a week between Dublin and Belfast by the company's steamers.

For upwards of three-quarters of a century this grand old company has faithfully served the public, with an immunity from loss of life as remarkable as it is gratifying to those chiefly concerned. 
Cinapter vi.

\section{THE BRITISH AND IRISH STEAM PACKET COMPANY, LIMITED.}

THE oldest deep-sea steamship passenger trade in Europe is that between Dublin and London. The distinction of having been the first persons (other than the crew) to cross the. Irish Sea by steam vessel is shared by Mr. and Mrs. C. R. Weld. Mr. Weld, who was the Secretary-or brother to the Secretary-of the Royal Society of Dublin, embarked with his wife on board the steampacket Thames, Captain Dodd, which vessel sailed from Dublin at noon on the 28th May, 1815, bound for London.

The sailing of this, the first, steamer between Dublin and London, was an event of the greatest interest to the citizens of the former city, who assembled in thousands to witness her departure. It was not intended that the Thames should ply between the two ports, and, as a matter of fact, it was not until after an interval of eleven years (1826) that a regular steampacket service was established between the Metropolis of England and that of Ireland. In the latter year, two of the City of Dublin Steam Packet Co.'s steamers, the Tramks (not the Thames of 1815) and the Shaxiox commenced to trade regularly between Dublin and London.

Amongst other famous steamers, employed on this station, may be mentioned the William Fawcest, which traded between London and 1)ublin during the summer of 1829. This steamer afterwards became the property of the Peninsular Steam Navigation Co., and is stated in Whitaker's Almanac (and elsewhere) to have been the pioneer steamer of the " $\mathrm{P}$. \& 0 . Co." In August, 1830, the steampacket Citr of Loxidoxinerre, built in 1827 for the Liverpool and Londonderry trade, and purchased in October, 1829, by the City of 1)ublin Co., was 


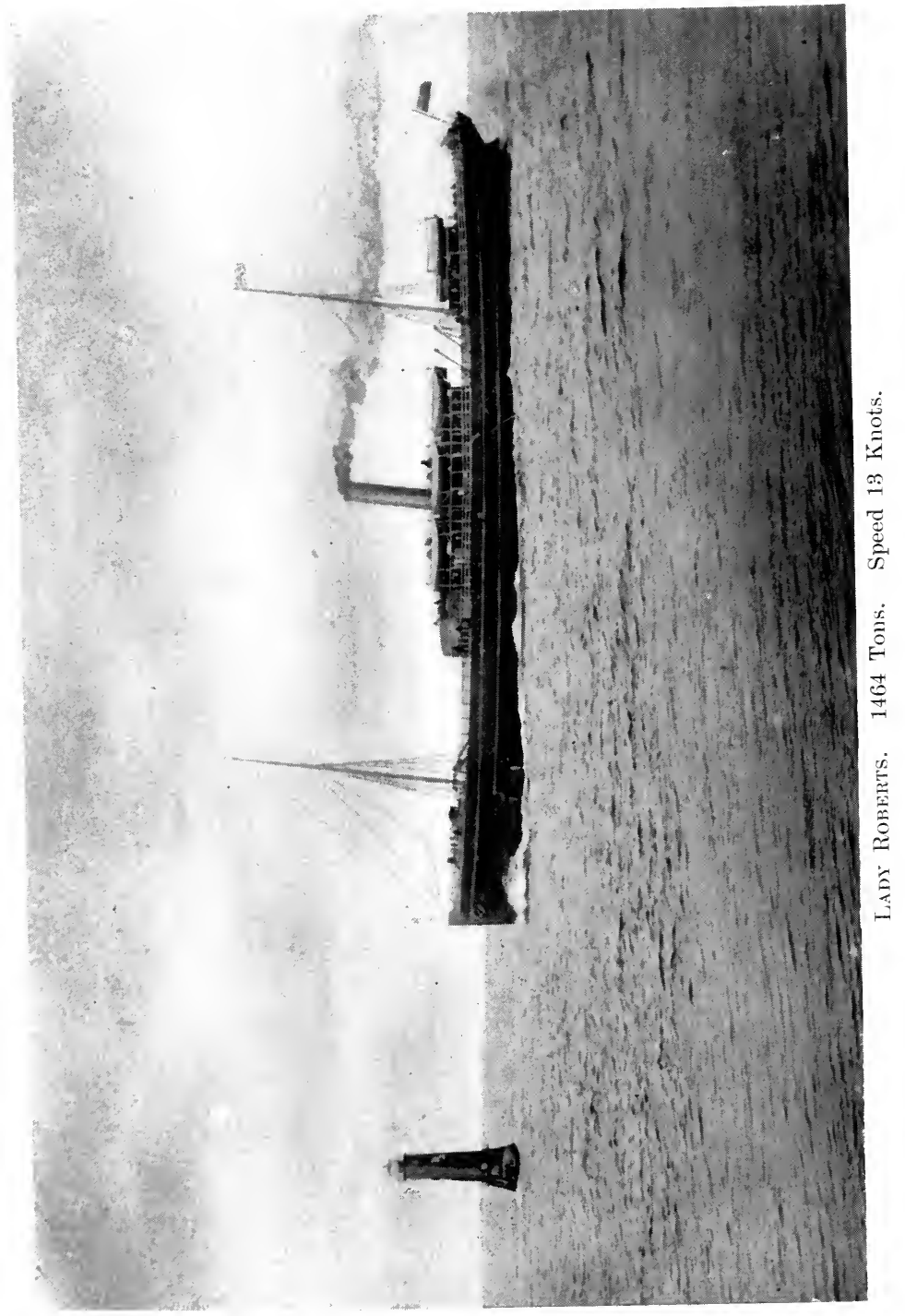


placed by her new owners on the London station. T'hese three steamers, the Thames, Shaxsox and ('ity of Loxmoxnerry, were described in the Company's advertisement of the period as being amongst the largest steamers aftoat, and all of the same eapacity and power, vi\%, 51:3 tons burthen, and 16i() h.p. each. These steamers maintained a regular weekly service (one of them sailing from London every Sunday, calling at Plymouth), and were due at 1)ublin in ordinary weather, in 80 hours after leaving London.

Travelling at that period was expensive, as shown by the rates charged by these small wooden steamers, compared with those now charged by the magnificent modern steamships of the B. and I. Co. of 1,400 to 1,500 tons each.

Cabin. Steerage.

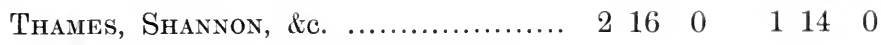

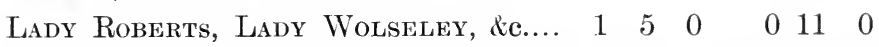

The present British and Irish Steampacket Company was established in 1836 . The list of the earliest Directors contained the names of several of the best known citizens of Dublin, the following being the names of the 1)irectors for the year 18:38, viz.--Messrs. James Ferrier, John MacJonnell, William Williams, Francis Carleton, Joseph Boyce, John Jameson, and fohn Ennis. The Company's first Heet consisted of three wooden paddle steamers, named respectively, Ciтr of Limirick, Devoxshire, and Shanvox.

A very ingenious robbery from the Company took place at the St. Katherine's Docks. Two boxes of gold dust, of a gross value of $£ 5,245$, were landed at Falmouth, ex H.M. lacket SEAGULL, from the Brazils. From Falmouth they were shipped per B. and I. steamer Citr of Limfrick to the Company's Wharf, London, consigned to the Brazilian Mining Co. It noon on Monday, 29th April, 1839, a person claimed the two boxes, and presented an order for them, apparently in the same handwriting as the letter of advice received with the two boxes from Falmouth. The advice stated that the boxes were only to be delivered to a gentleman who would all on Monday with a letter in the same handwriting. The "gentleman " accurately. described the marks, and took away the boxes; but two hours 
afterwards, another person, connected with the Brazilian Mining Co., came for the boxes, and the fraud was then discovered, for the genuine documents and letter addressed to the Company by the Falmouth Agent were produced.

Two months later, the whole of the criminals concerned were in custody, and charged with their offence at the Central Criminal Court. Two of them, Moss and Solomons, turned Queen's evidence. Lewin Caspar (who had been for eighteen months in the service of the B. and I. Co. as General Superintendent), was detained in custody until sentence was pronounced, 3rd February, 1840, and was then acquitted, owing to a flaw in the indictment. His father, Ellis Caspar, and Emmanuel Moses, were each sentenced to be transported for 14 years, and sailed for Sydney on the 20th October, 1840, on the convict transport, Lord LrNeDocir. Alice Abrahams (daughter of Emmanuel Moses) was also convicted of being an accomplice, and was sentenced to four months' imprisonment. Mr. James Hartley (founder of the firm of James Hartley \& Co., London) rendered very valuable service to the proprietors by his energy and skill in tracing and successfully prosecuting the thieves. Mr. James Hartley was elected a J)irector in 1838, and for his services in connection with the prosecution of the gold dust thieves, he was presented with a valuable piece of plate.

In 1842, the steamship Duke of Corwwall was built, and added to the fleet in order to meet the increased demands of the trade. Like her sister ships, she was a wooden paddle steamer, and the last of this type of craft employed in the service.

The British and Irish Steam Packet Co. were amongst the first steamship owners to recognise the advantage (now universally admitted) of the screw propeller over the paddle wheel as a means for propelling steamships, and in 1845 they introduced into the London and Dublin trade two schooner-rigged auxiliary screw steamers, one of which was called the Rose, and the other the Shamrock. Three years later the B. and I. Co. had to encounter a fierce and powerful opposition, engineered by the Messrs. Malcomson, of Waterford, but which 
involved nearly all the leading Steamship Companies on the East Coast of Ireland ; the B. and I. ; Belfast (Langtry's) ; City of Dublin; Cork; and Waterford Steamship Companies all taking part in the contest. The Waterford Steamship Company placed steamers on the London and Dublin station, and the Directors of the British and Irish Steam Packet Company retaliated by placing steamers on the Waterford and London, Waterford and Liverpool, and London and St. Petersburg lines. The opposition lasted until April, 1851, when an arrangement was come to, whereby the Dublin and London traffic was divided between Messrs. Malcomson (Waterford Co.) and the B. and I., and at the same time the City of Dublin Co. withdrew from their official connection with the latter Company. In the meantime, several steamers had been built of iron (notably the Great Britain), and had proved by the severest tests the great merits of that metal as a material for shipbuilding. So convinced were the Directors of the B. and I. of the advantages to be gained by the substitution of iron for wood, that they purchased in 1850 the first iron paddle steamer of the fleet. This steamer was named the Foyle, and was one of the finest vessels afloat in her time.

The following year witnessed an extension of the Company's operations, a regular service being established between Liverpool, South of England ports, and London; and also between Limerick and London. The latter was maintained by the auxiliary screw steamer Rose, and when this vessel was sold in 1852 , the service was discontinued.

To meet the increased requirements of the trade, two large screw steamers, the LAdY Lininton and the NiLE, were added to the fleet in 1852 .

On the outbreak of the Crimean War in 1854, two of the B. and I. steamers, one of which was the new steamer LADY Eglinton, and the other the Forle, were chartered by the Government for the conveyance of troops and stores. In consequence of the withdrawal of these two steamers from the Company's service, and of the loss of the NiLE off the Cornish Coast, the Liverpool to London sailings were abandoned.

In addition to her Government service in the Black Sea, the 
Lady Eglinton, in 1858, was employed for a short time as a Trans-Atlantic liner, making, in this capacity, two trips from Galway to Quebec and Montreal. In 1865, this famous steamer was placed in the hands of Messrs. Walpole, Webb \& Bewley, shipbuilders, Dublin, by whom she was lengthened thirty feet.

Prior to the declaration of War between the Northern and Southern States of America, in 1861, the B. and I. Co. had maintained a regular service between Dublin and Wexford. The vessel employed in this service was a small paddle steamer named the Mars. In 1863 the Mars was sold, crossed the Atlantic, and began the exciting career of a blockade runner.

Two years later (1865) the LADY Wodenouse was built in Dublin, for the Company, by Messrs. Walpole, Webb and Bewley, and in 1869 the same builders launched another B. and I. liner, the Countess of Dublin. The year 1870 saw an important and advantageous change in the fortunes of the Company, who purchased the interest and steamers of Messrs. Malcomson's London-Dublin line, since which time the sea trade between Dublin and London has been entirely in the hands of the British and Irish Company. The vessels purchased from Messrs. Malcomson were the Avoca and Сумв. In 1879 , the B. and I. Company was registered as a Limited Company, and a new steamer, the Lady Olive, 1,096 tons, was added to the fleet. The Lady OLive was the last iron vessel built for the Company, and the last of the compound engine type of steamer. All her successors-the present vessels of the fleet-are built of steel, and fitted with tripleexpansion engines. The first ship of the new type was the Lady Martin, of 1,356 tons gross register, built in 1887 by Messrs. Workman \& Clark, of Belfast. Her carrying capacity is much greater than that of any of her predecessors, and further increase of tonnage has marked all the vessels added to the fleet since. Her principal dimensions areLength 269 feet 6 inches, beam 34 feet 2 inches, and depth of hold 16 feet 4 inches.

She was followed in quick succession by the LADY HudsonKinahan, built by the Ailsa Shipbuilding Company, Troon, in 1891 ; the Lady Wolseler, built by the Naval Construction 
and Armaments ('ompany, Barrow, in 1894; and the LAns Robrrts, built by the Ailsa Shiplouilding Company, 'T'ron. in 1897. 'The last-named four steamers now carry on the trade between the two capitals, the LAm OLivi acting as stand-by ship. In their main features, all the vessels are very similar, and vary only slightly in size and power, from the Liss Martin, of 1,365 tons, to the LaDY Roberts, of 1,4ti2 tons. It will be seen from the particulars given, that the steamers of the 13. and I. Co. are amongst the largest coasting vessels in the United Kingdom. The average berthing accom-

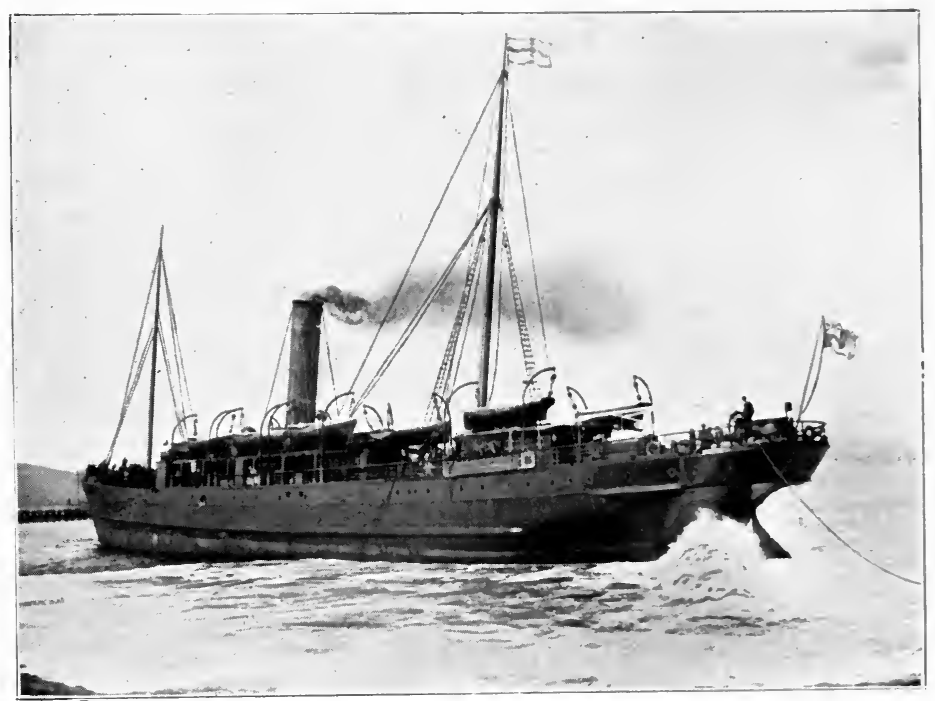

S.S. Lady Wolseler leaving Falmouth.

modation of each vessel is -120 saloon and 50 second cabin, in addition to steerage passengers. Each vessel is fitted up on the most approved plan, and electrically lighted throughout. l)eck cabins and state rooms can be secured at a small extra charge. Smoking rooms are also provided, as well as bathrooms. In the summer season pianos are put on board, and a full complement of stewards and stewardesses is carried. Under ordinary circumstances the vessels average 1:3 knots per hour, which is quite fast enough for the requirements of the trade; and it may 
be mentioned that they are well able to hold their own with the majority of channel steamers. Any person travelling by these steamers will find that very few vessels will pass them, and those which do are probably some crack mail packets running short passages.

The ships of the British and Irish Steam Packet Company are as well-known at Falmouth, Plymouth, Southampton, and Portsmouth as they are at the terminal ports of London and Dublin. Being so well-found, roomy, comfortable, and up-todate, and calling in at all the principal southern ports, it is but natural that they should be favourites with the holiday-making and touring public. So favourably are they held in this respect that during the "fine weather" months they seldom leave port without having a full complement of passengers, of whom (as has been stated) they are designed to carry a large number.

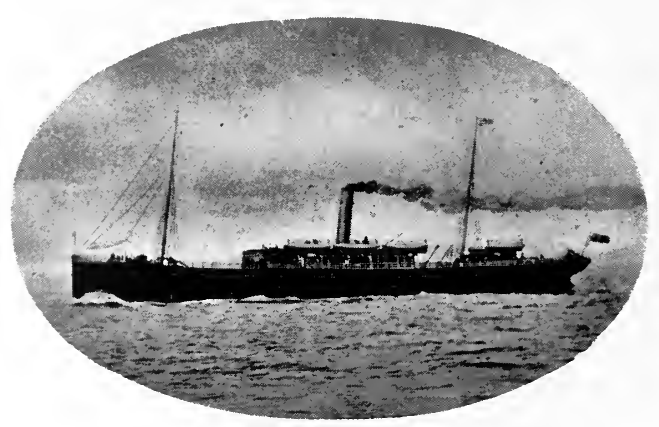




\section{Chapter ViI.}

\section{THE BIBBY LINE.}

REFERENCE has been made, in a previous chapter of this work, to this old-established firm. It was engaged in shipping in 1807, five years before the first British steamboat was launched. At that early date the fleet consisted of small sailing vessels, but in 1821 a regular line of ships to the East Indies was established. Of the old Liverpool shipowning firms which had their flag signal posts on Bidston Hill, only three now remain, viz., Messrs. Bibby, Brocklebank, and Sandbach Tinne.

In 1851 the firm, then under the guidance of the late Mr. James J. Bibby, went into the steam trade, their first boats, the Tiber and Arso, being built on the Clyde by John Reid and Co.

Mr. Bibby, in 1859, commenced entrusting the building of the steamers of the line to Messrs. Harland and Wolff, and from that date every succeeding vessel has been constructed by the same firm. It may be interesting to recall that the late Sir Edward Harland, who was the son of a personal friend of Mr. Bibby, commenced operations at Belfast with the order for the Siciliax, Venetian and Syriax.

Mr. Bibby adopted the system of building his boats on commission, a system which ensures the greatest co-operation between builder and owner, and by which he secured the greatest advantage wherever his interests were concerned.

The three boats last named were followed by the Egrptiax in 1861. All of these vessels carried elipper bows with figure heads and bowsprits, but the succeeding ships were built with straight stems, an innovation, the credit of which (and of many other improvements now generally adopted) is due to Mr. Bibby. The Iberian, Ildyrian and Istrian, all built in 1867, were the first of the fleet to carry the new type of bow, 


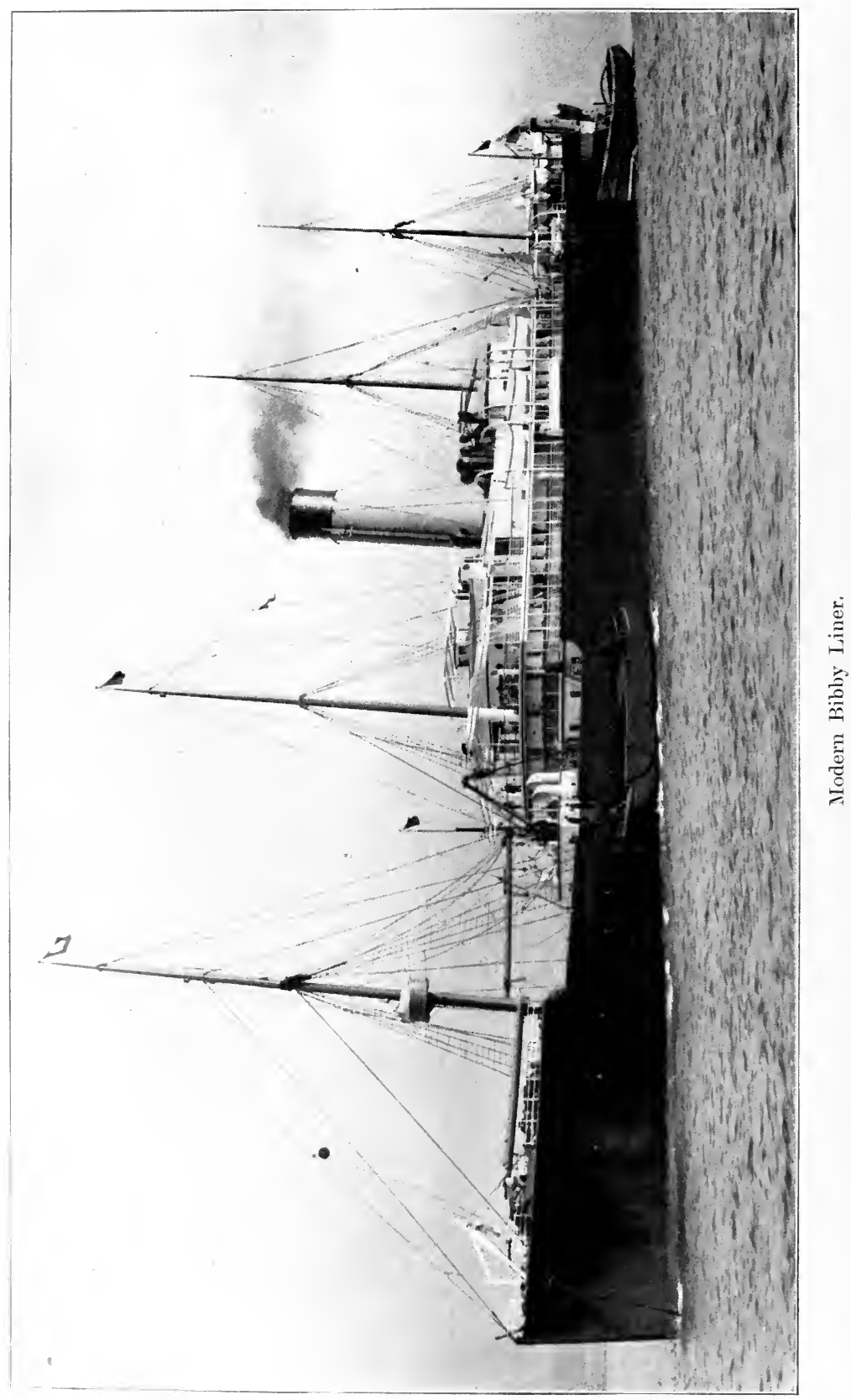


and they were followed by a long succession of well-known names, leading up to the present steamers on the Colombo and Rangoon and Southern Indian route.

This service, which was established in 1891, quickly became prominent among the fast passenger services, and, as such, was early recognised by the Government and placed on the list of the special lines available for officers, etc., returning at the expiration of their leave.

The pioneer vessel of the new service was the Yorkshirk, and her sister ship the Laxcasures (though both somewhat smaller than the later boats), still holds the blue ribbon of the route, having steamed from Liverpool to Rangoon in the fastest time yet on record. The CHesmine and SHropsure, which were the next steamers added to the fleet were each about 1,500 tons larger than their immediate predecessors. They were provided with two entirely distinct and separate sets of engines and propellers, a fact which at once arrested attention in the East, and greatly added to the popularity which their other arrangements justified. Intending passengers will be interested to know that with only one propeller in use, they are capable of making as good progress as an ordinary trading steamer.

After an interval of two years (1893) the twin-screw steamer STAFFORDSHIRE was built, and in her was emborlied every improvement which experience and money could provide. She was at once generally acknowledged to be the most comfortable and the best ventilated type of steamer placed on the Eastern route.

In October, 189i, the twin-screw steamer DErnsinne was added to the fleet. She is designed on the same lines as the STAFFornsmine but being 7 feet longer and 3 feet broader, her staterooms are somewhat larger. An important addition was made to the fleet in 190\%, when the twin-screw steamer WarwicksHIRE was built. ller arlvent on the line was looked forward to with much interest, and she has amply fulfilled all anticipations, and has secured a preference over any other steamer for first-class passengers between Ceylon and Europe. Her large size admits of 200 berths being fitted, and the Main 
Saloon, Drawing room, Smoke room, Bath room, etc., are all increased in their proportions.

By an ingenious arrangement (which is quite novel) every stateroom has a port opening to the outside of the ship, and all the rooms are equally light and airy, while many of the rooms provided are fitted up for the accommodation of one or two passengers only. The WARWICKsHIRE has marked a new era in the equipment of large passenger steamers, and the above mentioned Bibby Patent Stateroom is now being adopted by the principal Mail Lines in the construction of new boats. A twin-screw steamer, to be named the Worcestershire, is now under construction at Belfast. She is designed closely on the lines of the Warwicksmire, and is expected to be completed in good time to enable her to take her place in the Autumn sailings of 1904 .

The steamers of the Bibby Line sail on alternate Thursdays from Liverpool, calling at Marseilles to embark the overland passengers on the following Thursday. Circular tickets in connection with these sailings are issued for $£ 15$, which are available for a passage both ways by any steamer of the fleet, or if passengers prefer it, they will receive, free of additional cost, a first-class Railway ticket, via Paris, for the journey one way overland to or from London.

Travellers to and from Egypt, Palestine, etc., whether journeying round Spain or using the Marseilles route will find these steamers a convenient and luxurious means of conveyance.

The public will be glad to know that passages can be secured for $£ 3$ :s. for the fortnightly runs round from London to Liverpool. The steamers usually leave Tilbury on Friday, and arrive in Liverpool on the following Monday morning, thus affording a very pleasant week end trip.

The present fleet consists of the following modern fast Mail Siteamships :-

LANCASHIRE

ҮоRкSHIRE:

... 4244 Tons.

Cheshire...

... 4261,

StafFordShire $\quad \ldots$

... 6005 Tons.

SHROPSHIRE

... 5775 ,

Derbyshire

... 6636 ,,

S

... 5785 ,

WARWICKSHIRE

$\cdots$

... 7966 ,

WorCESTFRsHIRE (Building) 7966 ,, 
Chapter Vili.

\section{THE CORK STEAMSHIP COMPANY, LIMITED.}

The Cork Steamship Company, as successors to the St. George Steam Packet Co., may justly be considered to be one of the oldest existing steamship companies in the world. The original company (the St. George), was formed in the Autumn of the year 1821, its head-quarters being in Liverpool. An announcement concerning it appeared in the Liverpool "Mercury," of the 12th October, 1821, stating:--

"A company has been formed here (Liverpool) for

“ establishing steam packets.... Two vessels of large

"dimensions are already contracted for, and are now

" building by two experienced ship-builders in this town,

" the machinery for both to be fitted by an engineer of

" eminence; and the proprietors, we learn, are determined

" to spare no expense in the equipment of the vessels to

" contribute to the safety and comfort of the passengers."

In accordance with this announcement the pioneer steam packet of the Company, the St. Patrick, was launched from the yard of Mr. Thomas Wilson, Liverpool, at 10-30 a.m. on the 21st April following.

This event created quite a sensation in the town, as she was, if not the first steamer ever built in the port, certainly the finest specimen of ship-building craft up to that date constructed there. So great was the interest displayed that every wall and pier from which a view of the launch could be obtained was crowded with spectators. This steamer ran for about two years between various ports in England and Ireland, and having in that time established a reputation for speed and seaworthiness, she was purchased by a London Company to trade between London and Lisbon. She was replaced by a 
second St. Patrick, a vessel of 300 tons burthen and 120 h.p., built by Clarke and Nickson, Liverpool, and launched from their yard on the 19th August, 1825. In the interim between the dates of the launch of the first and second S't. Patrick, the Company had built or purchased quite a number of steamers. They had also established themselves in Cork, and had built the premises situated on Penrose Quay, where to-day is carried on the business of the City of Cork Steam Packet C'o., Limited.

The first three steamers employed by the St. George Co. in trading to and from ('ork, were the Les and SEvers, both built in Liverpool in 1825 (the former for the Liverpool trade and the latter for the Bristol trade), and the S'reser, built by Mr. William Evans, London.

The St. George Co. extended its operations with marvellous rapidity, until its steamers were to be found in almost every port in the United Kingdom, and in the chief ports of Holland, Denmark, and Russia. It owned several famous steamers, one of which, on the authority of Jeffry in "A Century of our Sea Story," made the first steam voyage between Great Britain and Australia. This was the SopHIA JANe, a vessel of 256 tons and 50 h.p., built by William Evans, London, and first employed between London Bridge and Gravesend. When first placed on this station, her owners were involved in an action at law to prove their right to navigate the river. They won their action from the Watermen's Company, and soon the first Gravesend Steam Ferry was started. The Sophia JANe plied on the Thames until 1828, when she began to make longer voyages, running for some months between Portsmouth and Plymouth, afterwards under the St. George flag, between Liverpool and Douglas (Isle of Man), later between London and Calais, and finally made her great voyage from England to Australia. She arrived at Port Jackson Heads in ILay, 18:31, three months after leaving the Thames, thus making the first steam voyage between Great Britain and Australia, and the longest voyage under steam down almost to the fifties.

Unfortunately the management of the St. George Co. was not 
all that could be desired, and the late Mr. Ebenezer Pike, of Bessborough, Blackrock, County Cork, convened a meeting of the shareholders which was held at Cork on the 1ith February, 1843. Prior to the meeting, Mr. Pike had forwarded to each shareholder a copy of a circular in which he proposed $(a)$ to form a Company with a capital of $£ 50,000$ in 1,000 shares of $£ 50$ each; and $(b)$ to build a new steamer of 500 to 600 tons burthen and 300 h.p.

The circular was discussed at the meeting, but no definite decision was arrived at. Mr. Pike, however, did not allow the matter to rest. In October following, so far as Cork was concerned, the title "St. George" was dropped, and the title "City of Cork Steamship Co." (afterwards shortened to "Cork Steamship Co.") was adopted in its stead. Mr. William Wilson, the founder of the firm of Wilson, Son \& Co., was the first general manager at Cork, and Mr. McTear the Liverpool agent. Nor did Mr. Pike abandon the idea of the new steamer, for on the 26th September, 1843, Messrs. Thomas Vernon \& Son built to his order the steamship Nimrod.

The following year the Company was virtually re-constructed, and the Cork Steamship Co. was formed with a capital of $£ 170,000$, in 1,700 shares of $£ 100$ each. The first Directors were, Messrs. Ebenezer Pike, John Gould, James Connell, Joseph Hayes, and William Lane, all merchants belonging to Cork.

At the date of the re-construction of the Company, the St. George Steam Packet Co. owned about 20 steamers. Most of them were disposed of to various buyers, the new management retaining seven, viz., the Lee, Severn, Tiger, Jupiter, Victory, Ocean, and Sirius.

The Lee and Severx have alrearly been referred to. The TIger was a steamer of 389 tons, built at Hull in 1838 . She was 156 feet long, by 26 feet beam, and 18 feet deep. She was rigged as a two-masted schooner and had a tiger figurehead. Originally she was intended for the St. George Hull and Hamburg service; was taken over by the Cork Steamship Co. in 1844, and sold by them in 1851 to London buyers.

The Jupiter was a vessel of 360 tors, built at Greenock in 
1835. Transferred to the Cork Steamship Co. in 1844, and sold by them to London buyers in 184 .

The Victori was a Liverpool built steamer of 256 tons, built in 1832. The Cork Steamship Co. did not retain possession of her long, but sold her in 1846 to the Malcomsons of Waterford, who employed her in their Limerick and London service.

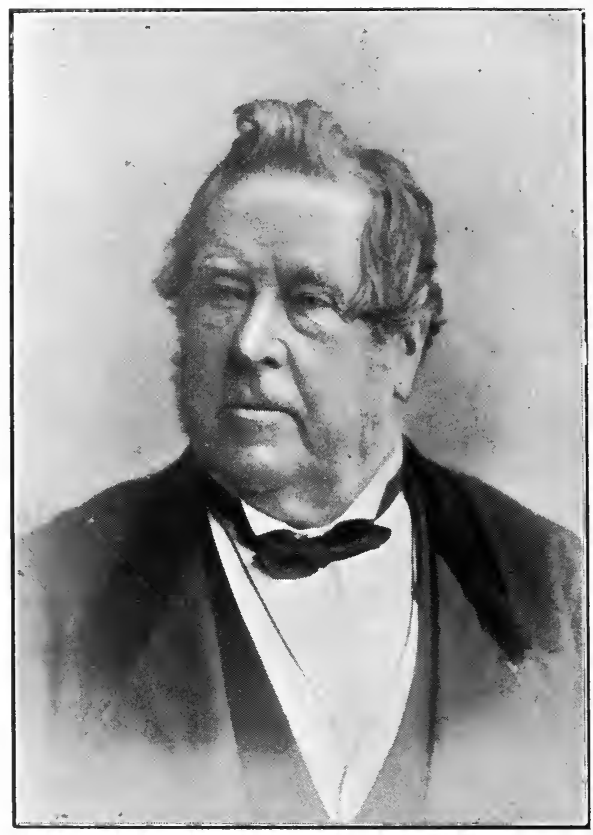

Mr. Ebenezer Pike, J.P. (late Chairman Cork Steamship Co.).

The OcEan was a steamer of 300 tons, her principal dimensions being 154 by 22 by 15 . She was built on the Mersey in 1836, and in 1838 made a record passage from Liverpool to C'ork in 23 hours. She was intended for the general Coasting Service of the St. George Co., and had the honour of acting as tender to her more famous sister-ship the Sirius, on the occasion of the latter's historic voyage to New York. Six years later when she had become the property of the Cork Steamship Co., she rendered valuable service to the Steampacket VANGUARD, belonging to the Dublin and Glasgow 
Steam Packet Co. During a gale on the 14th Jerember, 1844, the Vangurd, inward bound with a raluable eargo and a number of passengers, was forced on to the rocks about a quarter of a mile inside of Roche's Point Lighthouse. This occurred about 4 a.m., and soon afterwards the OcEAx, inwards from Bristol to Cork, passed the spot. The Vanguarn's signals of distress were noticed, and the Captain of the OcEax (Caldbeck), in spite of the heavy sea that was running, at once launched his boats, and succeeded in rescuing the VANGUARD's passengers. The steamer was afterwards towed off the rocks and taken to Passage for repairs. The OcEax continued in the service of the Cork Steamship Co. until 1853, when she was purchased by the Chester and Holyhead Railway Co. The remaining steamer transferred from the St. George Co., was the famous Sirius. The Sirius was built in $183 \pi$ by Menzies \& Co., Perth, and engined by J. Wingate \& Co., Glasgow; and cost $£ 27,000$. Her length was 208 feet, her breadth 25 feet, and her depth 18 feet. She had two masts and one funnel, and a dog figure-head, holding between the fore-paws a star, representing the dog-star Sirius, after which the vessel was named. On the occasion of her memorable voyage to New York, she sailed from London on the 28th March, 1838, under the command of Lieut. Richard Roberts, R.N., and called at Cork Harbour to coal and to embark the mails and passengers. The OCEAN arrived from Liverpool on the 3rd April with mails and passengers to be transferred to the Sirius. Next morning at 10 o'clock the Sirius got under way, being accompanied as far as the entrance to the harbour by the OcEAN. There, a brief stoppage was made while the OcEAx went alongside the Sirius to bring off a number of ladies and gentlemen who had been permitted to accompany their friends thus far, the steamers exchanged salutes, and then the Sirius continued her course, being watched with keen interest until she disappeared beneath the horizon. She arrived at New York at 10 p.m. on the 22nd April, and thus brought to a successful termination the first voyage ever made by a passenger steamer from Europe to America. She made two Trans-Atlantic voyages, and after- 


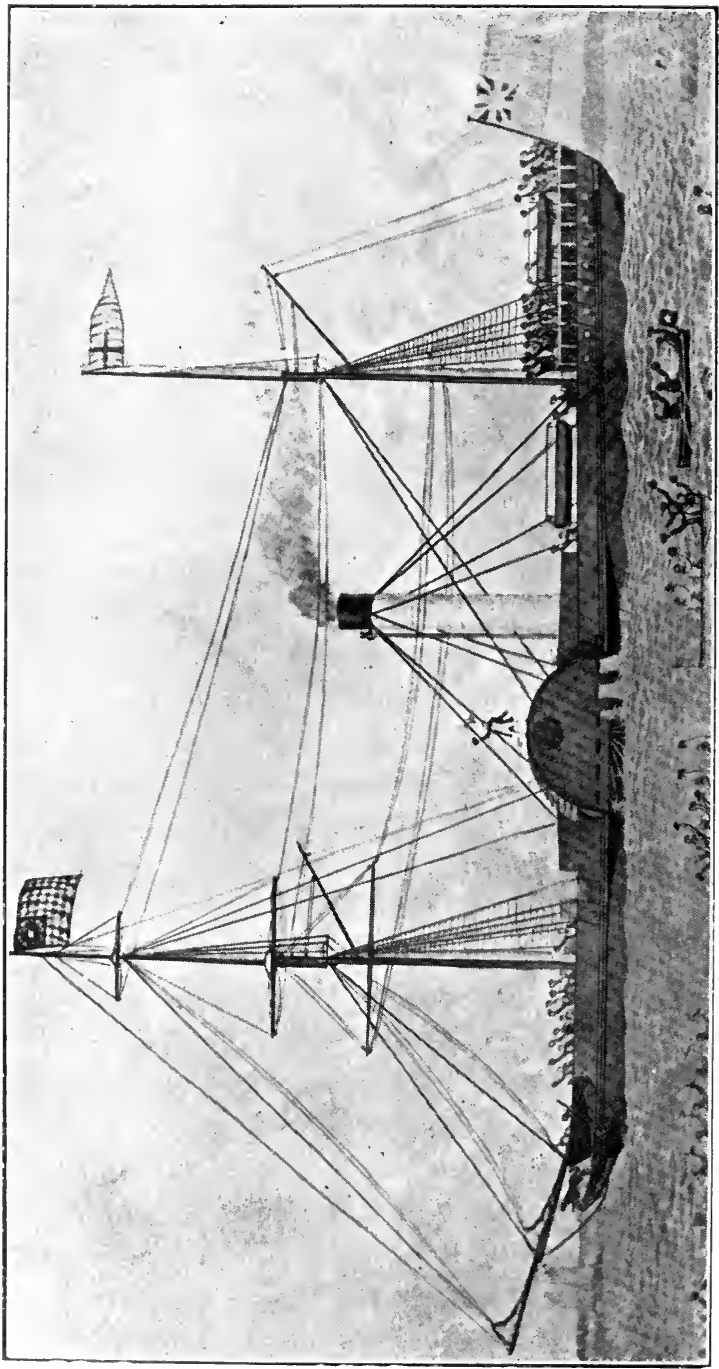

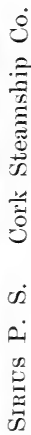


wards returned to the Home and Continental Services. When she became the property of the Cork Steamship Co. she was employed in the Glasgow, Dublin and Cork Service, in which she continued until 184\%. On the evening of the 15th June of that year, she sailed from Dublin to Cork with a general cargo, and forty passengers. All went well until 4 a.m. on the 16th, when she encountered a dense fog, and went on the rocks in Ballycotton Bay. Twelve passengers and two seamen were unfortunately drowned by the eapsizing of a boat which had been launched, but the rest of the passengers and crew were saved by means of a rope which was passed from the ship to the shore. The vessel itself went to pieces on the 22 nd June.

Nearly all the steamers retained by the new management were sold to various owners within a few years from the reconstruction of the Company, and new and more powerful vessels substituted for them. 'The first of these, the Nimrop, was the first iron steamship owned in Cork. She was built by Thomas Vernon \& Son, Liverpool, to Mr. Pike's order in 1843 , and was 177 feet long, 25 feet beam, and 16 feet deep. Her tonnage was 583 tons, and she had two masts, a clipper bow, and a huntsman (Nimrod) figurehead.

The AJax, a vessel of about 600 tons, was added in 1845 , and the Preussicher Apler, of 563 tons, also built in 1845, was purchased by the Company. The latter steamer was designed as an armed yacht for the late King of Prussia. She was built at Liverpool, and cost $£ 32,000$. She was a broad-beamed paddle-boat, having a beam of 28 feet, her length being 185 feet, and her depth $1 \tau$ feet. She was rigged as a two masted schooner, with a cutwater, an eagle figurehead. The Company, after purchase, added to her length, and for this purpose placed her in the Rushbrook Dry Dock, Cork, belonging to the Channel Dry Docks and Engineering Co.; the Preussicher ADLer being the first steamer to enter this dock. As originally designed her paddle-boxes were so constructed as to be capable of being turned down over her sides, in order that two large swivel guns which she carried on deck, might have a free range all round. 
She remained in the service of the Company until 1884, when she was broken up in London.

In 1846 Messrs. R. and J. Lecky, of Cork, built a small screw steamer to the order of the Cork Steamship Co. She was named the Blarner, and was only 118 feet long, 19 feet broad, and 11 feet deep. Notwithstanding her diminutive size, she ran for a number of years between Liverpool and Havre, and was eventually sold to a Liverpool firm in 1854. It is noteworthy that the BLARNEY was the first crosschannel steamer built in Cork by R. \& J. Lecky, and was the first screw steamer built for the Cork Steamship Co.

The year 1850 saw the Cork Steamship Co. involved in the most serious struggle which probably ever occurred in the coasting steamship trade. It began by the City of Dublin Co., at the solicitation of the Waterford and Kilkenny Railway Co., running opposition steamers to Waterford. The City of Dublin Co., in addition to their Liverpool and Dublin Service, had maintained for many years a regular service of steamers between Liverpool and Belfast. Mr. Joseph Malcomson (Waterford Steamship Co.) was a Director of the Cork Steamship Co., and his firm had a large financial interest in that Company. It was, therefore, to be expected that these two Companies would form staunch allies in any struggle, the more so, when the City of Dublin Co., in conjunction with the British and Irish Steampacket Co., extended the opposition to Cork. The Cork and Waterford Steamship Companies carried the war into their opponents' territory. They put a steamer on the station between London and the South and East of Ireland once a week, between Liverpool and Belfast twice a week, and between Liverpool and Dublin, daily. The City of Dublin Co. offered to make contracts with merchants in Cork and Waterford, undertaking to carry their traffic freight free for three months, in response to which the Waterford Co. threatened to place two steamers on the Holyhead and Dublin station in conjunction with the Chester and Holyhead Railway Co.

The struggle between the various companies was fiercely maintained for over twelve months, until in April, 1851, upon the suggestion of Mr. Malcomson, an interview took place 
between a Director of the City of Dublin Steam Packet Co. and himself (as representing the Cork and Waterford Companies), at which meeting the companies concerned arrived at an amicable basis of settlement.

In this settlement the City of Dublin Co. agreed to transfer their Liverpool and Belfast service to the Cork Steamship Co. This arrangement held good until 1854. On the 14th January of the year named a deputation from the Cork and Belfast Companies met in Dublin. There were present, Mr. Pike (Managing Director) and Mr. Glover (Secretary), of the Cork Steamship Co.; Mr. W. R. S. Lepper (Chairman) and Mr. Valentine, of the Belfast Co. The meeting was conducted in a most friendly manner, and it was arranged that the TeleGraPH (Belfast Co.'s stcamer) should be at once withdiawn from the Liverpool and Cork service, and the Minerva (Cork Co.'s steamer) from the Liverpool and Belfast service. The year 1854 witnessed a great stream of emigrants from Cork. According to a paragraph in the "Cork Constitution" of that date:-

"On Saturday, 1st April, the Minerva left with $46 \%$ adult emigrants, 79 children, and 8 infants, besides other passengers. The vessel was so crowded she had to leave 200 passengers behind. The Nimrop leaves every Wednesday, and is freighted with emigrants to a similar extent. This continual stream of emigrants has been going on for a considerable time."

While the war cloud was gathering over Europe, which in bursting produced the Crimean War, the Cork Steamship Co. had on the stocks a steamer, afterwards named the CormoRANT. Ir the equipment of this steamer a novel feature had been introduced, viz., iron masts. These masts, of which she carried three, were exceptionally tall and graceful, and so well buckled that not a joint was visible. The whole appearance of the vessel was so smart that she excited general admiration, and was selected by the Government as a transport. While she was lying at Portsmouth, after the embarkation of the 13th Lancers for the seat of war, Her (late) Majesty Queen Victoria, accompanied by the Prince Consort, came on board to inspect her before sailing. After inspecting the troopers' quarters, and 
admiring some of their horses, Her Majesty discovered that the ship's masts were not wood but iron. She was so impressed with their graceful appearance that she gave instructions for full particulars of them to be taken by the Dockyard officials

Two other steamers of the Company- the Dodo (nicknamed the rolling Dodo) and the Arbatross-were also engaged by the Government as transports. At the Crimea, as well as at home, the Conmoran's's masts excited great interest. One day a Turkish Admiral came on board, and a quartermaster was told off to show the distinguished visitor round the ship. The Admiral came to the mainmast, examined it, tapped it, and turning to his attendant, said :-

"I-ron?"

"Yes, your Excellency."

"Sō-lid ?"

"No, you blithering fool; it's hollow," was the reply, except that the adjective used was more forcible than the one we have given.

Amongst the vessels which were at the Crimea at this time was an American schooner, the captain of which was very proud of his craft, and was continually boasting of her beauty and of the lofty masts she carried. He " challenged creation to find her ditto." One day when he was boasting in his usual strain, Captain Byrne, who was present, said quietly, "What might the height of your masts be, captain?" "Every inch of 90 feet, I guess," replied the American. "Well," said Captain Byrne, "I can show you a ship with taller masts than that." "Where?" "In this harbour, on my ship."

To settle the dispute the two captains proceeded to the Cormorant. Now it must be confessed that the CormoRANT'S masts had not been scraped for some time, and were so streaked with paint and grease that they might easily be mistaken for pine. The American captain came to the foot of the mainmast and looked up. "Great Cæsar! What height do you call that?"

" 120 feet," replied Captain Byrne.

"Is it all one piece?" asked the other.

"There's not a splice in it from heel to truck," was the reply. 
"I calculate that timber was raised in Oregon," said the American.

"No, it was not."

"Well, do tell, where did it grow?"

"That, sir," quoth Captain Byrne, "was raised in Cork."

A collision occurred on the 10th July, 1866, resulting in the total loss of H.M.S. Amazox and the Cork steamship Osprex, with a number of passengers, chiefly ladies. 'The Osprex was outward bound from Liverpool to Antwerp, with a general cargo. She was under the command of the late Captain Bertridge, and carried a crew of 14 hands. When off Portland, at 1 o'clock in the morning, the look-out reported a steamer approaching, which proved to be H.M.S. Amazos. By a fatal error of judgment (for which he was dismissed the service) on the part of the officer in command, the Amazox crashed into the Osprex. While the vessels were locked together the crew of the Cork steamer scrambled over the bows of the man-of-war, leaving to Captain Bertridge the task of saving his family (who were on board) and passengers. These he placed in one of the boats belonging to the Osprex, cut the lashings, and had barely done so when his steamer sank, dragging the boat into the whirlpool as it sank, and drowning all in it, except the captain and one passenger. The captain's wife had previously jumped into the sea from the boat, and was rescued and taken on board the Axrazon. The latter vessel was so injured by the collision that she also sank about four hours later, but all on board took to the boats and were landed at Torquay.

About this period the question of the Company's house-flag began to ke agitated. The Cormoraxt, under Captain Croft, was lying at Penrose Quay, with her house-flag Hoating from the masthead. A section of the Channel Fleet happened to be in port at the time, and Captain Croft was surprised to receive a message from the Admiral commanding, asking why the Cormorant was flying his (the Admiral's) flag. Captain Croft replied that the flag he carried had been his Company's house-flag for the last twenty years, and of his Company's predecessor for over twenty years before that. To this the Admiral very courteously replied that he personally would not 


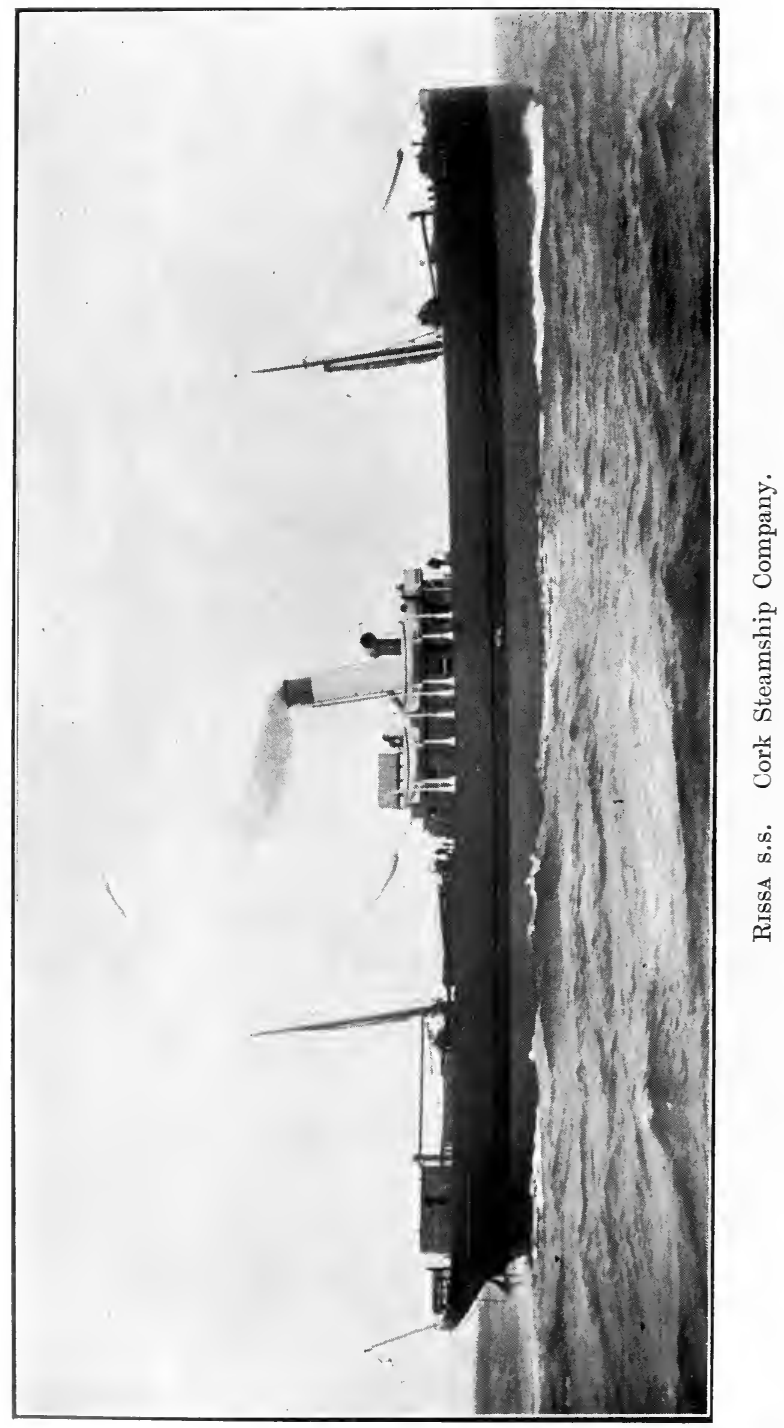


interfere with the use of the flag, but that as the Government had adopted it as an Admiral's flag, it was possible that some difficulties might arise later.

The question of the flag was next raised at Bussorah, in the Persian Gulf, on the ith November, 1882. The Dotrterk. had finished loading, and was getting ready for sea, when a message came from H.M.S. DRYAD, which was in the roadstead, asking why the DotTEksi dared to carry the Admiral's flag, and stating it must be pulled down at once.

"Tell your commander," said Captain Jobson, "that that flag is my Company's house-flag, and that I will not lower it without instructions from my owners."

The boat went back with this message, and Captain Dobson immediately sent a man aloft to grease the backstays and the masthead, having first nailed the flag to it.

In a short time the boat returned with a petty officer, whose instructions were, if the master of the DotTeres did not lower the flag, he was to send one of his men aloft to do so. "All right," said Captain Dobson. "I shan't pull my flag down; you can do what you please." The officer turned to his men and gave his orders. One tar after another tried to shin up the mast without success, and after several attempts the officer had to return and report the failure of his mission, and the Dotterel proceeded to sea.*

The commander of the man-of-war having reported to the Admiralty, a correspondence ensued between that Department of the Government and the Cork Steamship Co., resulting in the Company placing a blue star in the centre of the St. George's Cross on a white ensign, which now constitutes the distinguishing house-flag of that Company.

In 1871 the business of the Cork Steamship Co. had increased to such an extent, it was considered desirable to separate the coasting from the foreign services, and to form two distinct companies. This was accordingly done, the former being registered under the title of the City of Cork Steam Packet Co., Ltd.,

* Another account which bears the stamp of authority states that Captain Dobson did not carry off his flag in the manner stated. He lowered it under protest, and it was carried on board the man-of-war, but afterwards returned to the Company, and is now retained at the Head Office, Cork. 
and the latter under the style of the Cork Steamship Co., Ltd. Mr. Ebenezer Pike died in the year 1883, and was succeeded by his son, Mr. Joseph Pike, of Dunsland, co. Cork, as Chairman and Managing Director of the Company.

When the Manchester Ship Canal was opened in 1894, one of the first foreign trading steamers to pass through the canal was the IrIs, belonging to the Cork Steamship Co. The Cork Steamship Co.'s steamer Lestris was the first steamer to enter Flushing Docks on the 8th September, 1873, being locked in with the King of Holland's yacht.

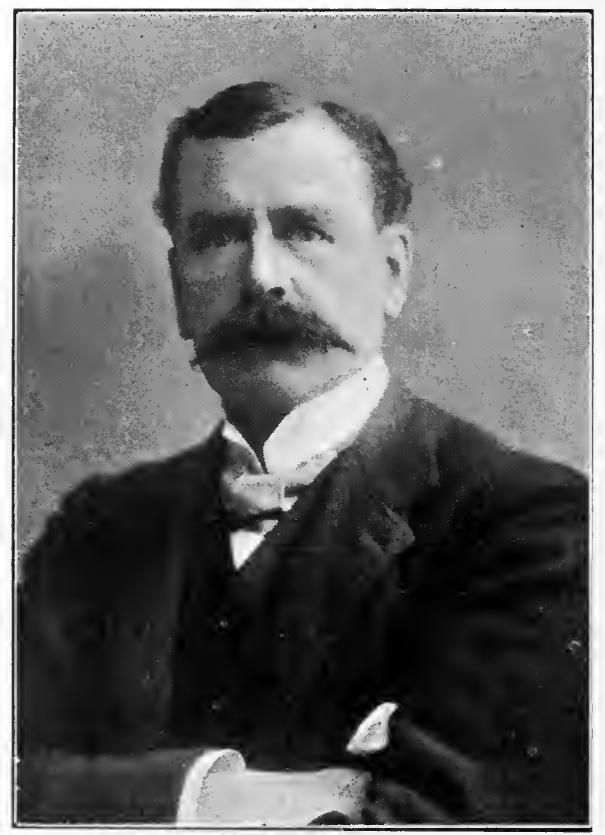

Mr. Joseph Pike, J.P., D.L., Chairman Cork Steamship Co.

The later years of the Company have been unproductive of historical incidents, perhaps not altogether to the regret of the shareholders. The older steamers have been disposed of from time to time, and replaced by modern steamers of larger tonnage and greater power. Instead of steamers of 500 to 600 tons, the fleet at the present time (1903) consists of 16 powerful vessels, varying from 1,000 to 2,400 tons. 
Chapter IX.

\section{THE CUNARD STEAMSHIP COMPANY,} LIMITED.

IT seems incredible that less than three-quarters of a century ago steamers were unknown on the Atlantic. The mail-boats of that date were wretched old Government 10-gun "coffin brigs," slow and uncertain in their passages. But there were men, even in those days, who dreamed of a time to come when steamers should cross the ocean with the regularity, though not with the speed, of railway trains. Amongst these enthusiasts was Mr. Samuel Cunard, a shipowner of Halifax, Nova Scotia. For years he had striven to realise his idea, but not having sufficient capital of his own, and not being able to induce his friends to invest in his enterprise, he had to wait his opportunity. At last the long-waited-for opportunity came, and he seized it. The British Admiralty issued a circular stating that the mails would be transferred to a steam packet service, if a satisfactory tender were sent in. When this circular came into the hands of Mr. Cunard he again appealed to the merchants of Halifax and others for assistance; and being unsuccessful in his application he came to Britain and fortunately became acquainted with Mr. R. Napier. Mr. Napier introduced him to Mr. George Burns who, in his turn, introduced him to Mr. David MacIver, of Liverpool. In the course of a few days, chiefly through the influence of Mr. Burns, the requisite capital, $£ 270,000$, was obtained, and soon afterwards a contract for seven years between the Government and Samuel Cunard, George Burns and David MacIver was signed, and the Cunard Steamship Co. was launched. Before their arrangements were finally adjusted, the Admiralty re-modelled the agreement, requiring that the service should be performed by four suitable steamers (instead of three, as originally stated), 


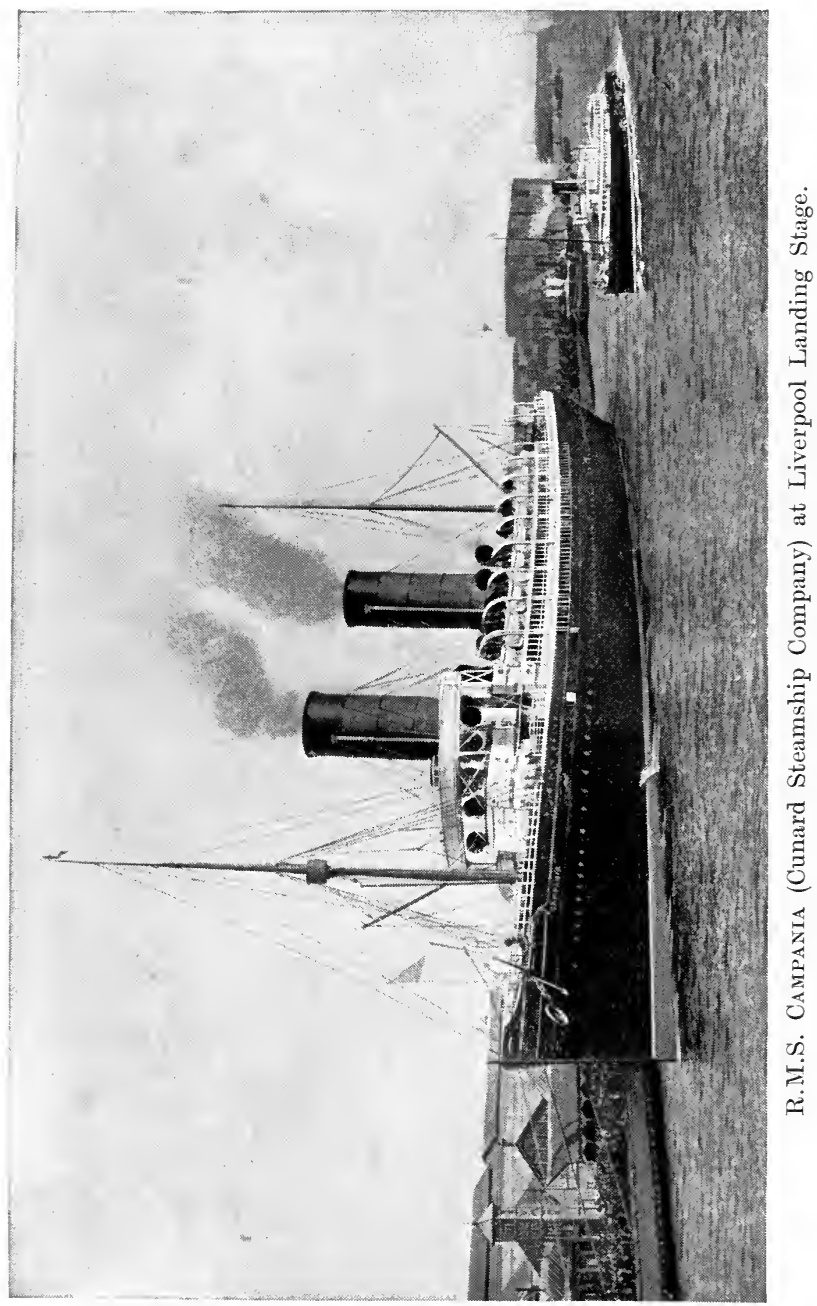


and that fixed dates of sailing should be arlhered to, but in consideration of the increased services the subsidy was raised from $£ 60,000$ to $£ 81,000$.

The official title of the Company was "The British and North American Royal Mail Steam Packet Co.," but this unwieldy title soon gave place to one of world-wide reputation, "The Cunard Line."

The first steamer despatched by the co-partnery was one of Messrs. Burns' Liverpool and Glasgow steamers, the Uxicons. She sailed from Liverpool for Halifax and Boston, under the command of Captain Douglas, on Saturday morning, 16th May, 1840. She carried the mails and a limited number of saloon passengers, the passage rates being-to Halifax $£ 30$, to Boston $£ 33$ each. The Britansia, the pioneer steamer of the British and North American Steam Packet Co., was despatched on the 4th July, 1840, being the first of four wooden paddle-wheel steamships, the others being the Acadia, Caledonia and Columbia. These vessels were uniform in size and power, being 207 feet long, 34 feet 4 inches broad, and 22 feet 6 inches deep. Their gross tonnage was 1,154 tons, and their engines of 740 I.H.P. drove them at an average speed of $8 \frac{1}{2}$ knots per hour. The reception given to the Britarxia on the termination of her maiden voyage by the citizens of Boston was most enthusiastic. Nor was the goodwill of the merchants confined to banquets and complimentary speeches for, when the Britaxia was ice-bound in Boston Harbour, in February, 1844, they liberated her by cutting a canal through the ice, seven miles long and 100 feet wide.

In 1843 the Company added to their fleet the Hibersis, and in 1845 the CAmbria, each of 1,040 I.H.P. and of 1,422 tons gross, with an average speed of $9 \frac{1}{4}$ knots. On the expiration of the Postal Contract the Government stipulated that the existing mail service should be doubled, that the steamers of the Company should be capable of carrying guns of the largest calibre, and that a steamer should leave Liverpool every Saturday (calling at Holyhead if required) for New York and Boston alternately ; the Boston steamer to call at Halifax, and the New York steamer to do so also, if required by the Lords Commissioners of 


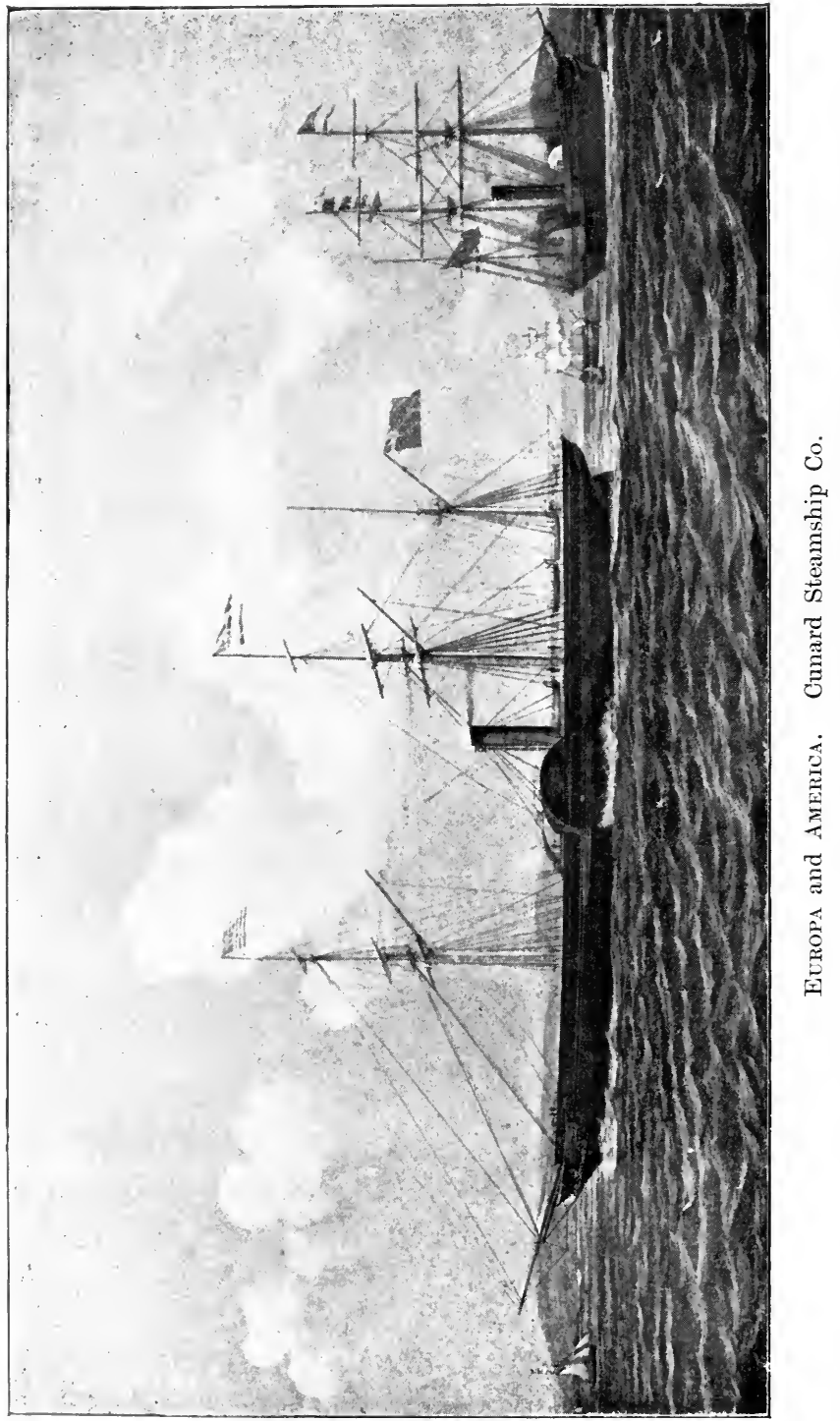


the Admiralty. In consideration of these augmented services the annual subsidy was increased to $₫ 173,340$, at which figure it remained for twenty years (1847 to 1867 ). T'o meet the new requirements, the America, Niagara, Canada and Europa, of 1,825 tons, and 2,000 I.H.P., with an average speed of ten and a quarter knots, were built and added to the fleet. A few years later the Collins Line, heavily subsidised, was started with the avowed object of "sweeping the Cunarders off the Atlantic." This opposition lasted until 1858, when, having lost two ships, and being refused any further subsidy by the United States Government, the Collins Company collapsed, and the remaining ships were withdrawn. During the continuance of this opposition the Cunard Company added steadily to their fleet larger and more powerful steamers. The Asia and Africa were built in 1850 , and were each 266 feet by 40 feet by $27 \cdot 2$ feet, of 2,226 tons gross, with engines of 2,400 I.H.P., and of an average speed of 12.5 knots. These were followed in 1852 by the Arabia, the last of the wooden paddle steamers. She was 285 feet long, 40 feet 8 inches broad, and 29 feet deep. Her engines indicated 3,250 H.P., and her average speed was 13 knots per hour. Three years later, 1855, the first iron mail steamship was built for the Cunard Company. She was named the Persia, and was nearly one hundred feet longer than the largest of her predecessors. Her principal dimensions wereLength 376 feet, breadth 45 feet 3 inches, depth 31 feet 6 inches. Her gross tonnage was 4,000 tons, and her engines indicated 4,000 H.P., giving a speed of $13 \cdot 8$ knots per hour. In 1853 the Company established (primarily as auxiliaries to their Atlantic service) branch lines between Liverpool and Havre, and Liverpool and the principal ports in the Mediterranean, Adriatic, Levant, Bosphorus, and Black Sea. For these branch lines the screw steamers Sydney, Australian, Andes and Alps were built in 1852, followed by the JURA in 1854 and the ETra in 1855. War having been declared against Russia the four lastnamed steamers, in addition to the Cambria, Niagara, Europa and Arabia, were engaged by the Government as troopships. The Cunard Company had in 1854 purchased the steamer Emeu, and she was immediately chartered to the Government. The 


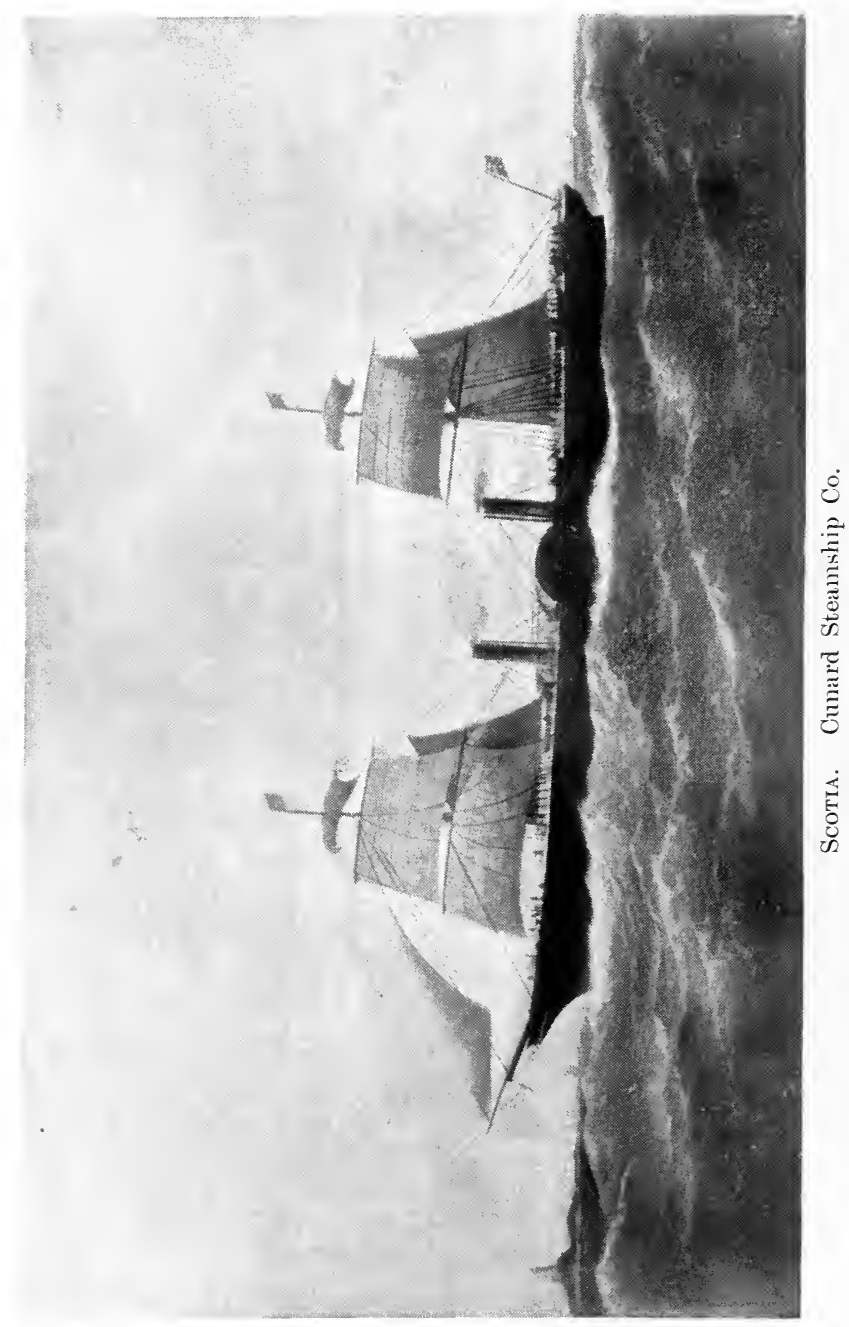


EMEU was the first troopship to arrive out at the commencement of the Crimean War, and in the seventeen months following she conveyed upwards of 17,000 troops to the Crimea. A few years later (1862) the famous Scotia (the last of the parllle-wheel steamers) was built. In $18 \% 8$ she was sold to the Telegraph Construction Company, who converted her into a screw steamer. The same year (1862) the Cunard Company ordered their first screw steamer for the Atlantic trade. This was the Cnina S.S., now converted into a four-masted barque and named the Theodor. She was followed in 1864 by the Cuba, in 1865 by the JAVA, and in $186 \%$ by the Russia, of 2,960 tons gross and 3,100 I.H.P. After sailing for many years under the Cunard Flag, the Russia was sold to the "American Line." Her new owners lengthened her, gave her a fourth mast, and altered her name to the WAEsLand. She finally sank off Holyhead, after colliding with the S.S. Harmoxides, on the 5th March, 1902.

The Company's Postal Contract having expired on the 31st December, 1867 , a new contract was entered into with the Postmaster-General for one year, whereby the Cunard Company undertook to despatch a steamer from Liverpool to New York, calling at Queenstown, returning from new York every Wednesday, also calling at Queenstown. The payment for this service was $£ 80,000$, which sum was further reduced the following year to $£ 70,000$ per annum for several yearrs. Under the last contract, which was for the period named, the Company guaranteed to sail a steamer from Liverpool (calling at Queenstown) to Boston every Tuesday, in addition to the mail service from Liverpool to New York every Saturday. The lastmentioned contract expired on the 31st December, 1876, on which date a new system of postal remuneration came into operation based on the amount of correspondence carried per voyage, under which system the Cunard Company has carried the mails to the present time. It will thus be seen that the continuity of their mail service has continued unbroken for upwards of sixty years. The invention of compound engines was the latest evolution of marine engineering engaging attention in 1869-70. The Directors of the Cunard Company quickly realised that the saving eftected by the use of compound engines 


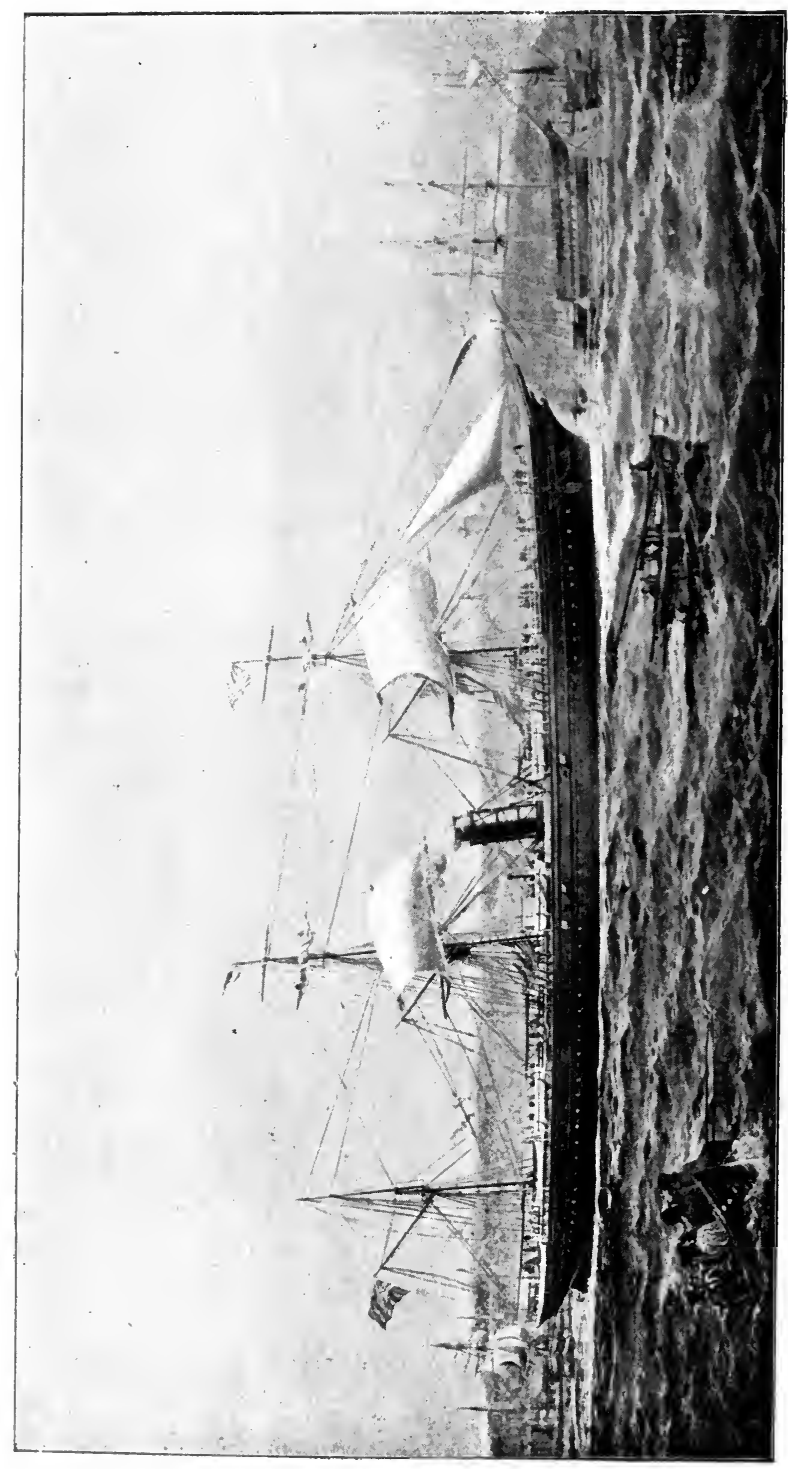

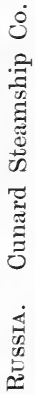


was so considerable, without reduction of speed, that their adoption was an imperative necessity. This decision was arrived at too late to furnish with the new style of engines the Abrssinia and Algeria, each of about 3,300 tons and 2,480 I.H.P., just completed by Messis. J. \& G. Thomson, and placed on the New York station; but the BAtavia, then on the stocks to the order of another company, was purchased and supplied with machinery on the new principle; and an order was given to the same builders (Messrs. Denny, 1)umbarton) for a similar vessel of rather larger tonnage to be named the Partira. A further extension of the Company's business took place in 1872 , by the establishment of a direct line of steamers between the Clyde and the West Indies. The Trinimad and the DEmerara, two sister ships of about 2,000 tons each, were built that year, and placed on the station, but after about twelve months' trading they were withdrawn, and sent to supplement the Company's service in the Mediterranean. Iouring the succeeding six years the fleet was increased by the addition of seven large steamers, all fitted with compound engines, the last and largest of which was the GALLIA, of 4,809 tons and 5,300 I.H.P.

In 1878 it was considered expedient to consolidate the interests of the partners by registering the Company under the Limited Liability Acts, and a Joint Stock Company was formed with a capital of $£ 2,000,000$, of which $£ 1,200,000$ was issued and taken up by the families of Cunard, Burns and MacIver. No shares were offered to the public until 1880, when a prospectus was issued intimating that "it was now proposed to issue the balanse of the capital." 'The available shares were rapidly subscribed for, the representatives of the three founders retaining a large financial interest in the Company. About this period steel was engaging the attention of shipbuilders as a substitute for iron. The Cunard Directors were so convinced of the superiority of the former, especially where speed was a desideratum, that they ordered a steel steamship from Messr's. J. \& G. Thomson, to be larger and more powerful than any steamer previously built, the Great EAsters alone excepted. This monster vessel, which was named the SErvid, was com- 
pleted in 1881. Her dimensions were-Length 515 feet, breadth $52 \frac{1}{10}$ feet, depth $3 \pi$ feet. Her gross tonnage was 7,392 . Her engines were compound-with seven steel boilers-and developed 10,000 I.H.P., producing a speed of 17 knots per hour. She was fitted in the most substantial and beautiful manner for the accommodation of 480 cabin and 750 steerage passengers, and embodied all the most modern appliances conducive to comfort and safety. She was the first of the Cunard Fleet to be equipped with incandescent electric lamps. The same year, the Catalonia, 4,841 tons and 3,200 I.H.P., was built for the Boston service, and two more for the same service in the following year. These were the Pavonia, of 5,587 tons and 4,000 I.H.P., built by Messrs. J. \& G. Thomson; and the Cephalonia, 5,517 tons and 4,000 I.H.P., by Messrs. Laird Brothers, Birkenhead.

A second steel steamship was built in 1883 for the New York Mail Service. This was the Aurania, built by Messrs. J. \& G. Thomson, and her dimensions are 470 feet by $57 \frac{2}{10}$ feet by $37 \frac{2}{10}$ feet. Her tonnage is 7,269 , and she is fitted with compound engines of 9,500 I.H.P., and attaining a speed of $17 \frac{1}{2}$ knots per hour. She was taken up by the Government as a transport in October, 1899, and so valuable did she prove for this service that she was retained until the early part of 1903 . In 1884 the Directors purchased the celebrated iron steamship Oregon, built by Messrs. John Elder \& Co. She was 501 feet by $54 \frac{2}{10}$ feet by 38 feet, and of 7,375 tons and 13,500 I.H.P.; speed 18 knots per hour. On her first and second voyage she did not distinguish herself, but on her third voyage she made the passage from Queenstown to New York in 6 days 10 hours 9 minutes, thereby excelling all previous records, and earning for herself the title of "The Greyhound of the Atlantic." Towards the close of 1884 the UMrria-the first of two steel steamships ordered from Messrs. Elder-was delivered, and she was followed early in 1885 by her sister ship the ETruria. The following description of the ETruria applies also to the Umbria: Length $501 \frac{6}{10}$ feet by $57 \frac{2}{10}$ feet by $38 \frac{2}{10}$ feet; gross tonnage 7,718 tons. The promenade deck, which extends over the full breadth of the ship for nearly 300 feet amidships, 
is reserved for the sole use of the first-class passengers. The vessel easily accommodates 550 first-class passengers and 800 third-class. The state rooms are replete with all the fittings usual in first-class vessels of the most modern type, and a number of them are arranged en suite for family use. The hull is divided into ten watertight compartments, and most of the bulkheads are carried to the upper deck, while they are fitted with waterproof and fireproof doors, which aftord access to all parts of the ship. The engines indicate 14,500 H.P., and are compound, having three inverted cylinders-one high-pressure 71in. in diameter and two low-pressure, each 105in. in diameter. The average speed of both steamers may be set down at $18 \frac{1}{2}$ knots per hour. The fastest passage of the LTruRIA was when she established a new record by making the passage from Queenstown to New York in 5 days 20 hours 55 minutes, the Umbria's best record being 5 days 22 hours 7 minutes. The next important addition to the fleet was the CAMPANia, launched from the yard of the Fairfield Shipbuilding Co., Govan, on the 8th September, 1892. Five months later-February, 1893there was launched from the same yard her sister ship the Lucania. From the official description of the Campaxia, it appears that her length over all is 620 feet, extreme breadth 65 feet 3 inches, depth from upper deck 43 feet, gross tonnage 12,950 tons. The bulkheads are sixteen in number, and they will enable the vessel to float with any two, or in some cases three, of the compartments open to the sea. Although fitted with twin screws, there is an aperture in the stern frame similar to that in a single screw steamer. This is provided that the propellers may work freely, though they are fitted close to the centre line of the ship, in order to prevent damage to or from the quay walls. In the accommodation for passengers all the latest improvements are to be found, and everything calculated to render ocean travelling more comfortable and enjoyable is introduced. The grand saloon, drawing room, library and smoking rooms are noble in their proportions, and suggest the stately chambers of a palace rather than accommodation within the steel walls of a ship. It is worthy of special notice that comfort has been studied in every detail, and perhaps nothing 


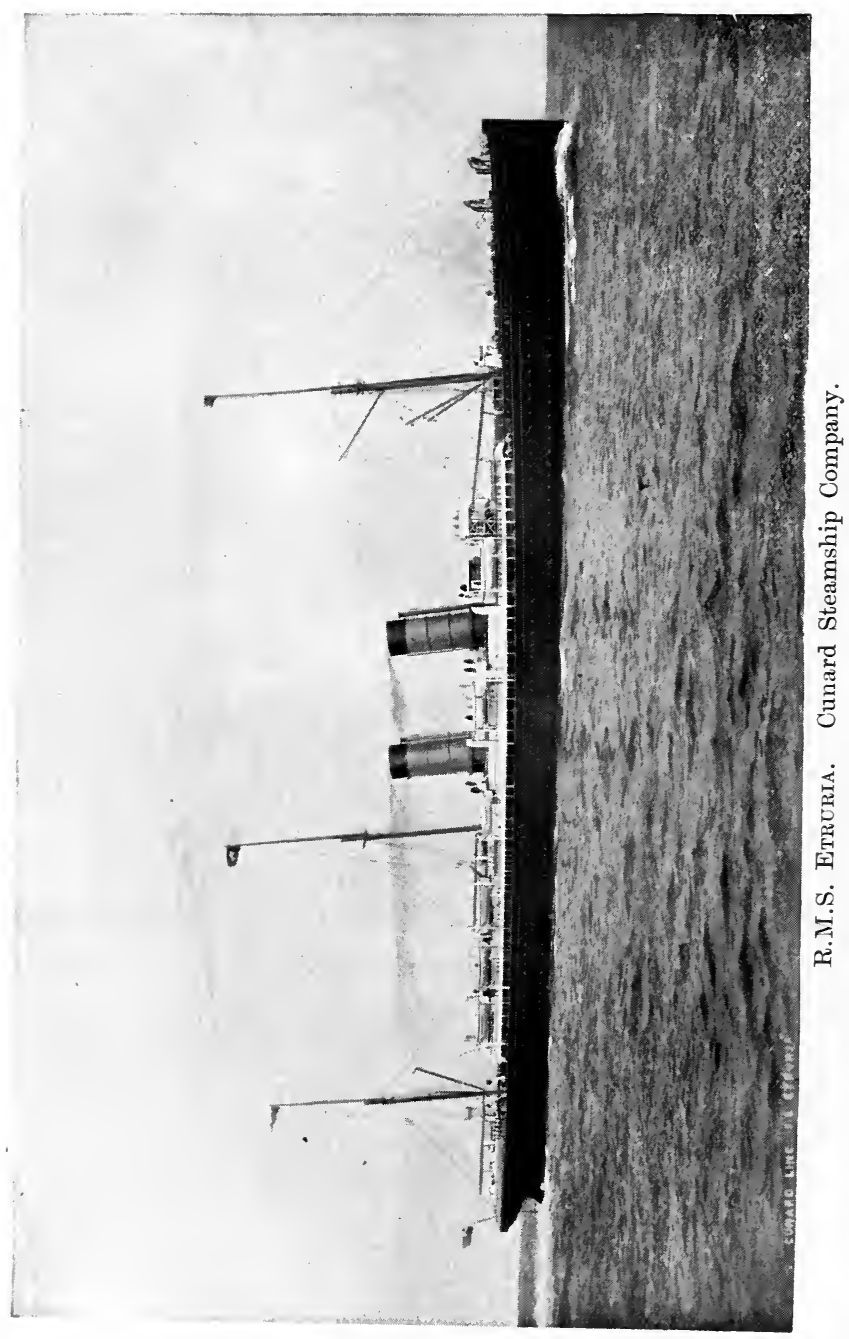


exemplifies this more than the fact that in all the principal rooms there are coal fire-grates, the first that have pver been used on board ship. There are four sets of generating plant, capable of supplying throughout the ship 1,350 16-candle power incandescent electric light, and in addition a powerful searchlight, for facilitating the navigation into port, \&c. Wire to the length of 40 miles runs through the ship. The grand saloon is a magnificent hall in the modified Italian style, 100 feet long by 63 feet broad, with seats at table for 430 passengers. In the centre, a great crystal dome rises through the two decks above to a height of 33 feet.

Three classes of passengers are carried by the Campania, viz., first, second and third class; and roughly speaking there is accommodation for about 1,400 passengers and 400 crew. While the hulls of both vessels are almost unrivalled in size and in the accommodation they afford, the machinery by which they are propelled is almost unique in magnitude and skill in construction. The two sets of triple-expansion engines in each ship develop the enormous amount of 30,000 I.H.P. The funnels of the Campania and Lucania from their lowest section are 120 feet high, or about the height of the Eddystone Lighthouse, and their diameter 20 feet.

The Campania has maintained an average speed for twelve months, on her eastward runs, of 21.88 knots per hour, while the Lucania for the same period shows an average speed of 22.01 knots. The Mediterranean service has within the last few years been greatly improved by the addition of four new steel steamships, each of about 3,000 tons burthen. These are the Pavia (1897), Trria (1897), Crpria (1898) and Veria (1899). The Boston service also comprises the following modern steel twin-screw steamships:-Ivernia and SAxosia, built in 1900, the UltoNia in 1898, and the Srivasia in 1895. The Ivernia and Saxonia are practically alike, and call for some special notice. They are the largest ships carrying passengers and cargo to Boston. The principal dimensions of the ships are-Length 600 feet, beam 64 feet 3 inches and depth 41 feet 6 inches. The gross tonnage is $14,02 \pi$ tons, measurement capacity 20,000 tons, while the displacement is no less 


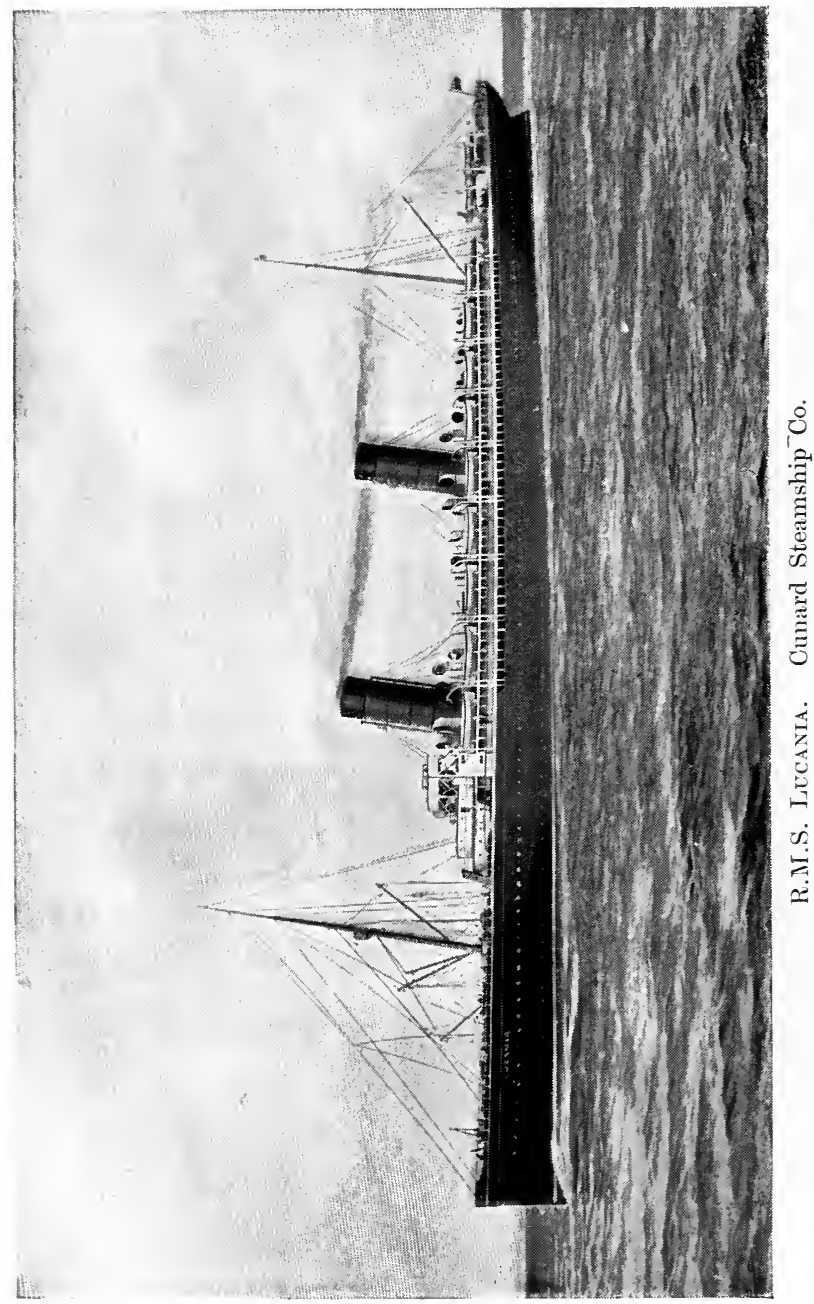


than 25,000 tons. In their ordinary work across the Atlantic they carry 200 first, 220 second, and about 1,900 third-class passengers. If engaged in trooping, each ship could carry 200 officers and 3,500 men, together with 10,000 tons of stores. The features of the ships, next to their huge size, are the spaciousness and comfort of their passenger accommodation and their steadiness, which is most remarkable, and which makes sea sickness almost impossible. Aerial telegraphy is in regular operation on board these two vessels. The Cunard was the first steamship company to systematically adopt this latest development of electrical science. It was in the Lucaria that Mr. Marconi's system was first set up, and so pleased were the Directors with the results that they at once decided to adopt the invention in their other steamers, the Camparia, Lucasia, Etruria, Umbria, Carpathia, Auraxia, Ivernia and SAxonia all being now thus equipped.

In October, 1903, the Lucasia was the medium selected by the inventor for further experiments in wireless telegraphy, and on the voyage from New York to Liverpool completed on October 10th, Signor Marconi successfully accomplisher a wonderful feat, and a newspaper with real news fresh from the Marconi stations at Cape Breton, Nova Scotia, and Poldhu, Cornwall, was published every day. Messages were transmitted over a distance of 2,000 miles as accurately as over the same number of feet or yards, so that passengers on board the LuCANIA had their printed newspaper, the "Cunard Bulletin," every day of the voyage, containing the most interesting events on both continents. Just before arrival in Liverpool a larger edition of the "Cunard Bulletin," a weekly issue, was printed giving an epitome of the news recorded in the six daily publications during the voyage, and marking a fresh era in oceanic journalism.

The Carpatira, the latest addition to the Cunard fleet, represents a new departure in Atlantic trade, being designed exclusively for second and third-class passengers, all of whom are accommodated in rooms containing two and four berths. The dimensions of the CARpatila are-Length 560 feet, breadth 64 feet 3 inches, depth 40 feet 6 inches, and the gross 
tonnage is 13,555 tons. She started on her maiden voyage May 5th, 1903, and being built on similar lines to the Ivernia and SAXONIA shares their reputation for remarkable steadiness at sea even in the stormiest weather.

A recent item of interest in connection with this famous company is the agreement made in August, 1903, with the British Government, by which the Cunard Company are to build two new steamers of an average speed of not less than $24 \frac{1}{2}$ knots, which, along with all other Cunard ships, are to be at the disposal of the Admiralty for hire or purchase whenever they may be required. To help them in this undertaking, such fast ships being unprofitable for commercial purposes, the Government lend the Company $£ 2,600,000$ to build the ships, and grant them a subsidy of $£ 150,000$ a year.

In October, 190:3, the Cunard Company started a new Winter Passenger Service from New York to the Mediterranean ports, calling at Gibraltar, Algiers, Naples, Palermo, Venice, Trieste and Fiume. The Aurania and Carpathia, carrying only two classes of passengers, were chosen for this new service, which opens up a round of most interesting travel to the great travelling. public of moderate means. Passengers by these steamers may land at any of the ports named and visit at leisure places of interest in Spain, France, Italy, Germany, Sicily, Austria or Hungary, continuing their journey overland to England to return to New York by Cunard steamer from Liverpool; or, if they prefer to do so, they may remain in the ship all the time and return in her to New York; or, as a third course, they may make a stay in any of the countries named and rejoin a subsequent Cunard Mediterranean ship at any of her calling ports.

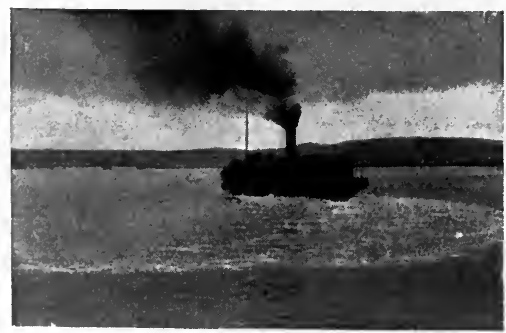


Chapter X.

\section{HOUSTON LINE.}

This well-known line of steamers was established about a quarter of a century ago by the present senior partner of the firm, Mr. R. P. Houston, Member of Parliament for the Toxteth Division of Liverpool. Like many other undertakings which have grown to gigantic dimensions from small beginnings, this firm started in a modest manner with one small steamer. This was the steamer Athlete, followed in the year 1881 by a larger steamer, the Hercules, built by the Whitehaven Ship Building Co., and engined by Messrs. J. Jones \& Sons, of Liverpool. She was a vessel of 742 tons net register, and 1,155 tons gross register, her principal dimensions being, length 212 feet, beam 34 feet and depth 16 feet 6 inches. Her engines, which were of 150 nominal horse-power, were compound. These two vessels were not engaged in any regular trade, but ran wherever profitable freights coud be obtained, and chiefly to Java and Eastern ports. Becoming too small for Messrs. Houston's requirements, they were sold. All the succeeding vessels of the fleet, of which there have been a great many, have been named after Greek mythological deities or Roman celebrities, each name beginning with the letter " $\mathrm{H}$."

Although already very busily engaged with large contracts for the conveyance of material to the Panama Canal Co., and the West African Co., Mr. Houston, believing there was ample room for a new line of steamers to the River Plate from 


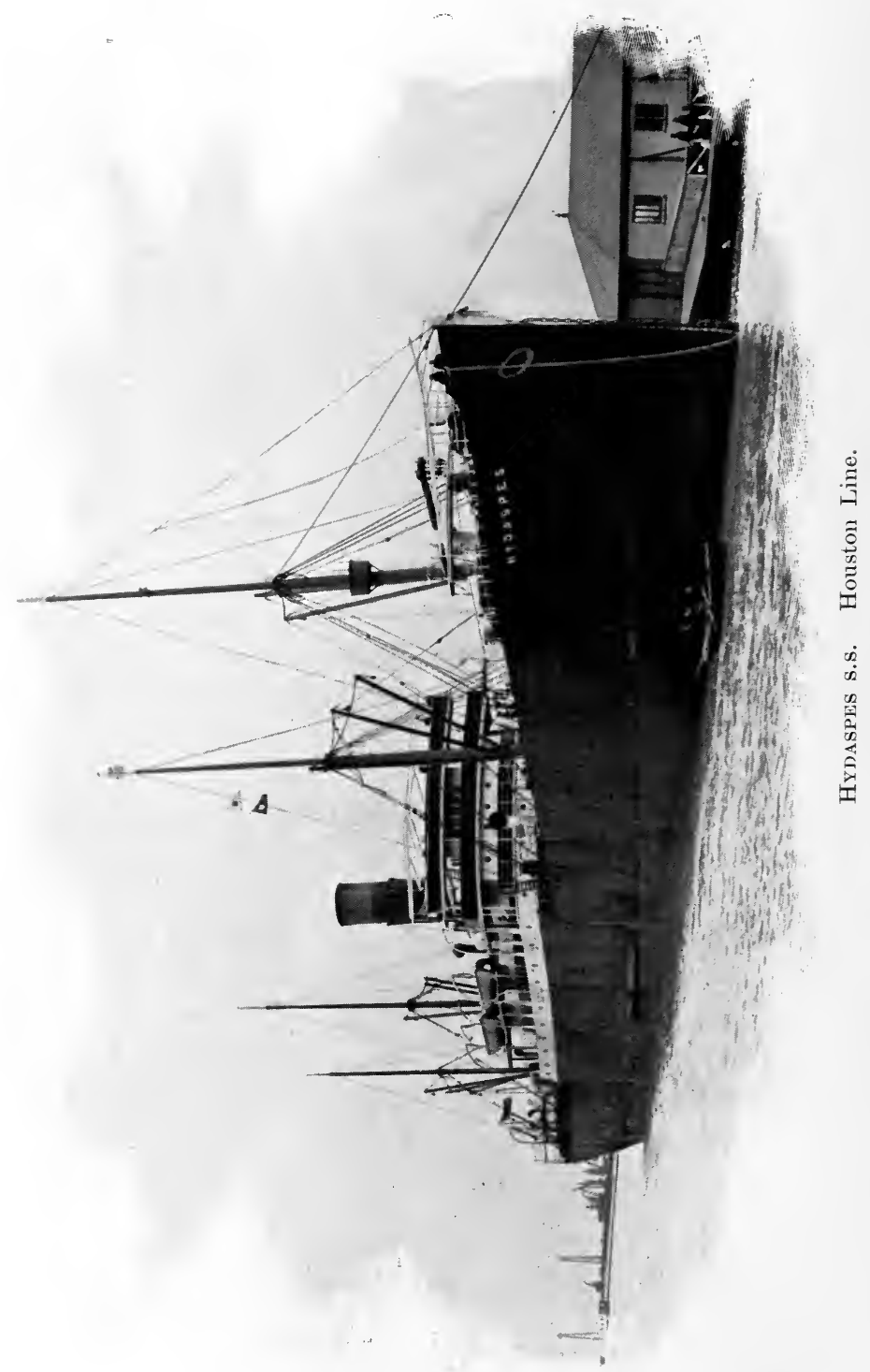


Liverpool, decided to enter upon that trade in the year 1884. New steamers were designed and built specially for this trade, and so energetically and successfully was the trade worked that, although severe opposition was encountered at first from the existing lines, in a short time not only were Messrs. Houston's steamers fully occupied, but many steamers had to be chartered to meet the rapidly increasing traftic, since which time the Houston Line has assumed very large proportions.

The first steamer engaged in this trade was the Hersus, built on the Clyde in 1882, and engined by Messis. J. Jones and Son, Liverpool. She was a much larger vessel than the Hercules, her gross register being 2,175 tons, and her principal dimensions 290 feet in length by 40 feet beam and 22 feet depth.

After a short interval more steamers, each of about 2,000 tons gross, were added to the fleet in 1884 . These were the Hellexes, built by Richardson, Duck \& Co., and engined by G. Clark, of Sunderland-length $2 \pi 0$ feet, beam 40 feet, and depth 18 feet 7 inches; and the Hesperines, built by R. \& J. Evans \& Co., and engined by George Forrester \& Co., Liverpool-length 286 feet, beam 38 feet, and depth 24 feet. The following year (1885) a larger boat than any yet built for the firm was added to the fleet. This was the Heliades, built by Richardson, Duck \& Co., Stockton. She was 320 feet long, and of proportionate beam and depth. Her gross register was about 3,000 tons, and she was fitted with tripleexpansion engines by 'T. Richardson \& Co., of West Hartlepool, with which class of engines all the succeeding steamers have been fitted. A sister ship, but having more powerful engines, the Heraclides was launched for the firm in July, 1886. She was followed in 1889 by the Hippomeses, built at Belfast by Workman, Clark $\&$ Co., and the Hroarnes and the Hellopes, built at Port Glasgow by J. Reid \& Co. These steamers, like their immediate predecessors, were each of about 3,000 tons gross register, and were all practically of the same dimensions. The whole of these four steamers are fitterl with refrigerators for the earriage of frozen meat from the River Plate. 
Mr. Alfred S. Collard, a gentleman with a large and varied experience in the River Plate trade, and one thoroughly conversant with the working and requirements of an important steamship line, joined Mr. Houston as partner in 1893.

During the closing years of the last and beginning of the present century the quantity of railway rolling stock and plant for shipment to the River Plate was so great that it was not an uneommon event for the Brunswick Station of the Cheshire Lines Railway to be almost entirely blocked with wagons of railway material eonsigned for shipment by the Houston Line. So large were some of these packages, they could only be brought through from the manufaeturers on Sunday, it being impossible to eonvey them on the railway while the ordinary traffie was being carried on. In 1898 Messrs. Russell \& Co., of Port Glasgow, built two sister ships of over 3,500 tons gross register for Messrs. Houston. These were the Herminius and the Horatius.

The year 1899 was an important one in the firm's history. In that year the trade between New York and the River Plate was entered, and since that time a regular service has been maintained, the pioneer steamer being the Hermes (the second of that name). She was a steel built steamer of 3,400 tons gross, driven by triple expansion engines of about 2,500 horse-power effective. She was launched at Sunderland in January, 1899, and is of the following dimensions:-Length 350 feet 2 inches, beam 47 feet, depth 17 feet. She was the first of a fleet of seven similar vessels which were launched to the order of the firm during the course of that year, the others being the Hovorius, Hortensius, Hrades, Hydaspes, Hylas, and the Hranthes.

The following year, the last of the 19th century, saw one more steamer, the Hostilius, added to the Line.

Frequent as were the additions to the Houston Fleet, they were not sufficient to keep pace with the expanding trade, which increased so rapidly that many outside steamers had to be chartered. When ex-President JKruger sent his fateful ultimatum to the British Government, which resulted in the South African War, Messrs. Houston \& Co. were amongst the 
first to offer their steamers to the Admiralty for the conveyance of troops, horses, mules, fodder, \&c. It was of the greatest importance that ships should be fitted up for the transit of troops and animals for transport purposes as quickly as possible, and this was carried out by the Houston Line with eminent satisfaction to H.M. Government. The principals and the staff worked night and day, and spared no efforts in despatching quickly the men, horses and stores so urgently required at the seat of war. Large numbers of horses, mules and stores were carried by the Houston steamers from the United Kingdom, the Continent and the United States to the various South African ports with a gratifying immunity from loss.

It may be stated here that the senior partner of the firm is an expert engineer, and that all the steamers built for his firm, and which have been so remarkably successful, have been built from specifications and designs drawn up by him.

As has been stated, many of the steamers are fitted with refrigerating machinery for the conveyance of frozen meat, and are regularly employed in this trade. These steamers are favourably known for the excellent condition in which they deliver their cargoes, and in order that the live stock should be landed in the very best possible condition, the steamers were fitted up with permanent cattle fittings, and made in every way suitable for successfully carrying live stock.

The Houston Line River Plate steamers take cargo from Glasgow, Liverpool and New York for Monte Video, Buenos Ayres, Rosario, \&c., without transhipment, which is a very important matter in the opinion of shippers.

It is a matter of common knowledge that a very serious fight is being waged (1903) in the South African shipping trade, owing to the entrance therein of the Houston Line. In July, 1902, sailings from Glasgow, Middlesbrough, Bristol, Liverpool and London (as well as from New York) to Cape Town, Algoa Bay, East London, Durban and Delagoa Bay were announced by the Messrs. Houston. The Steamship Lines then engaged in the trade had formed a Conference or " ring." The members of this "ring" are the Union-Castle Line, the 
Clan Line, the Bucknall Line, the Harrison-Ellerman Line, J. T. Rennie \& Co., and Bullard, King \& Co., forming the strongest shipping ring ever known. It is this shipping " ring" that the Houston Line is opposing.

Great public interest in the struggle has been excited by the many angry and strongly worded letters from shippers which have been published from time to time in the current Press regarding the modus operandi of the "ring." Tactics of such a character have been adopted by the " ring" as will, we understand, form a subject of an action in the Courts of Law, as they have already provoked discussion and protest in various Chambers of Commerce, and have even been discussed in the House of Commons.

From present appearances the Houston Line is growing steadily in favour of shippers to the Cape ports, and having now been in the trade for over twelve months it must have secured a firm foothold. Certainly shippers and merchants generally welcome and support this "Line" as having a beneficial influence upon the trade between this country and our South African Colonies.

The latest built and largest steamers of the fleet are engaged in the Cape service. Amongst them are Hyacinthus, Halizones, Hydaspes and Hypatia, with an average dead weight carrying capacity of about 9,000 tons each.

We understand several large carrying steamers are in course of construction for the firm.

As showing the great increase in the size of the firm's vessels, it may be interesting to compare the dimensions of one of the earliest and of one of the latest built ships.

The Hercules was 212 feet long, 34 feet broad and 16 feet 6 inches deep.

The Hypatia is 452 feet long, 52 feet 2 inches broad, and 28 feet 3 inches deep.

The gross registered tonnage of the former was 1,155 tons, while that of the latter is over 5,600 tons.

The growth of the Houston Line has been a remarkably rapid one, and shows what ability and energy combined can do. 
The fleet now consists of 25 steamers of a gross registered tomnage of over 90,000 tons, and with a dead weight carrying capacity of over 130,000 tons.

Houston Line Steamers.

$\begin{array}{llll}\text { Halizones. } & \text { Heraclides. } & \text { Hippomenes. } & \text { Hyades. } \\ \text { Harmodius. } & \text { Herminius. } & \text { Honorius. } & \text { Hyanthes. } \\ \text { Harmonides. } & \text { Hermione. } & \text { Horatius. } & \text { Hydaspes. } \\ \text { Heliades. } & \text { Hesione. } & \text { Hortensius. } & \text { Hylas. } \\ \text { Helios. } & \text { Hesperides. } & \text { Hostilits. } & \text { Hypatia. } \\ \text { Hellenes. } & \text { Hilarius. } & \text { Hyacinthus. } & \text { Hyperia. }\end{array}$

Hellopes.

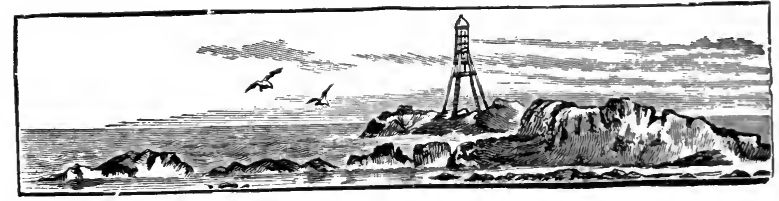




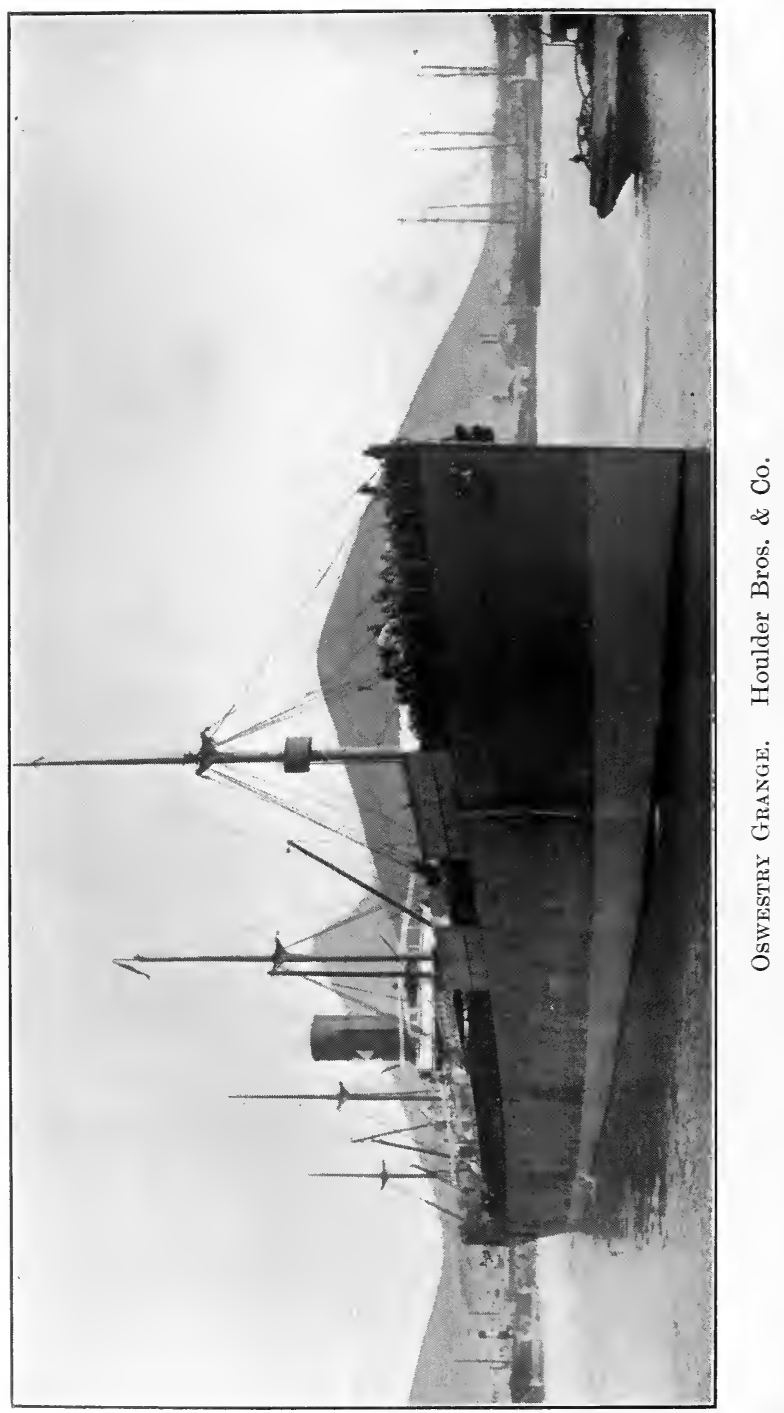




\section{Chapter XI.}

\section{HOULDER LINE.}

The Company was founded by the late Mr. Edwin Savory Houlder in London in 1849, and he was subsequently joined by his brothers Messrs. Alfred and Augustus Houlder. At first the business was confined to sailing-ships, a fleet of Clipper Packets sailing under the firm's flag between the home ports and Australia being established. As the business increased, the firm became in turn interested in the South African and South American Trades, the development of their steam fleet receiving a large amount of attention, until, at the present time, it includes some of the largest and most successful frozen meat carriers afloat.

The principal services now maintained are between the United Kingdom and South America, between South America and the Cape ports, between Australia and New Zealand and the Cape ports, and from New York to Australia and New Zealand, although many other trades of the world claim the Company's attention and for these trades a large amount of tonnage is chartered annually.

The Headquarters are in London, with Branches at Liverpool, Glasgow, Sydney, N.S.W., Cape Town and Buenos Aires; also sub-offices at Rosario and La Plata.

With one exception, the steamers of the Fleet are distinguished by the affix Graxge. The first were the Horsix Grange (3,750 tons burthen) and Ovingdeax Grange (3,520 tons burthen), launched in the opening months of 1890, both vessels being insulated throughout for carrying frozen meat, as are all the other steamers of the Line. They were followed in 1894 by the Urmston Grange, designed to carry 5,420 tons. 


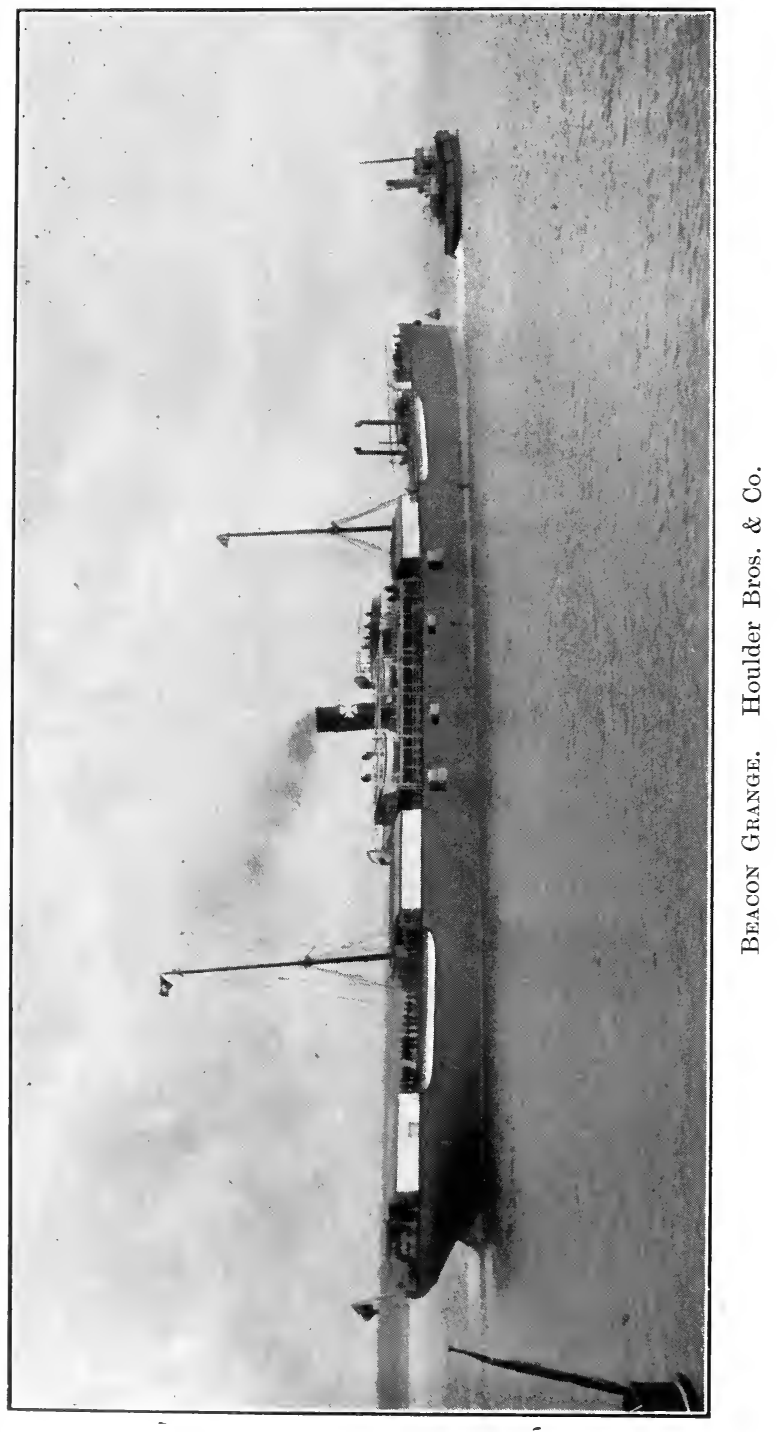


In 1896 two important additions were made in the shape of the steamers Langton Grange and Dentox Grange, each having a deadweight eapacity of 9,200 tons, and like the earlier steamers insulated in the most efficient manner for carrying frozen meat. In the meantime two more steamers were acquired, the Elstree Grange and the Soutiers Cross, the latter being placed in the Australian trade in company with the Langton Grange and Denton Grange, whilst the former was taken into the River Plate service which had grown to such an extent as to justify the addition of two further vessels, larger and faster than any of the earlier ships in the trade. These were the Royston Grange and Bracon Grange, each 6,400 tons burthen, and capable of making the passage between England and the River Plate in twenty-two or twenty-three days.

For the Australian trade the Rippingham Grange, a sister ship to the Langton Grange, was added in 1898.

At this juncture, the various steamers comprising the fleet were amalgamated into one Company under the name of the Houlder Line, Limited, this step being taken in order to consolidate the business generally, and to ensure more systematic and economical working.

Previous to this, however, the firm of Houlder Bros. \& Co. was converted into a Limited Company, the partners in the old firm becoming Managing Directors of the new Company, Mr. Edwin Savory Houlder acting as Chairman until his death in 1901.

To return to our description of the fleet. To replace the Denton Grange (unfortunately lost at Las Palmas) the Company contracted for the Drayton Grange, a fine four-masted, twin-screw steamer of 10,000 tons burthen, launched in December, 1901, and also for a sister ship, the Oswesrry Grange, launched a few months later. Both of these steamers, and, in fact, the other large vessels of the fleet, did excellent service during the South African War.

The fleet, at the present time, consists of fourteen steamers, three boats having been added since the launch of the Oswestry Grange, as the following list will show:- 


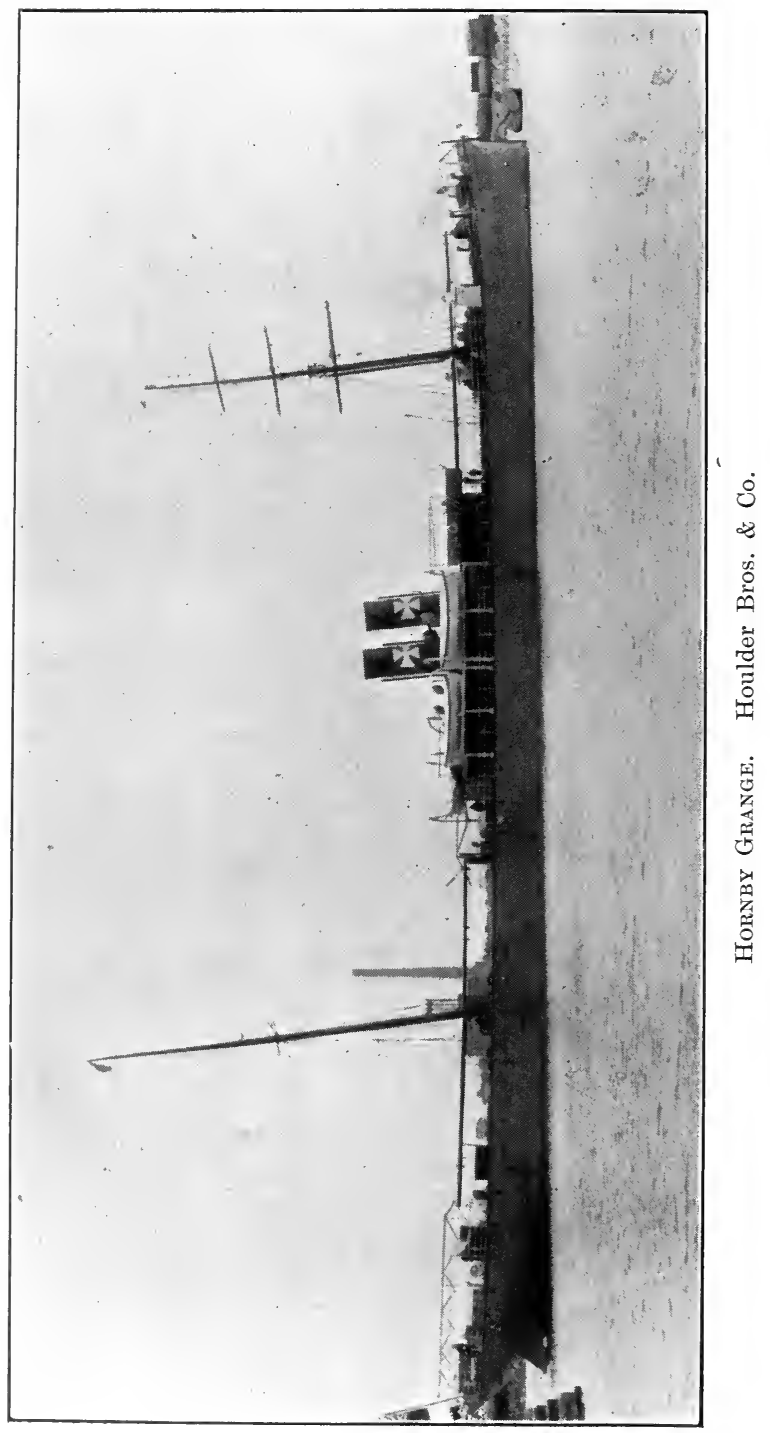




\begin{tabular}{|c|c|c|c|}
\hline Hornby Grange & $\begin{array}{l}\text { Tons BURTHEN. } \\
\ldots \quad 3,750\end{array}$ & Beacon Grange & $\begin{array}{l}\text { Tons Burthen. } \\
\ldots \quad 6,400\end{array}$ \\
\hline Ovingdean Grange & $\ldots \quad 3,520$ & Rippingham Grange & 9,200 \\
\hline URMSTON Grange & $\ldots \quad 5,420$ & *Oswestry Grange & ... 10,000 \\
\hline Langton Grange & ... 9,200 & Thorpe Grange & $\ldots \quad 6,350$ \\
\hline *Drayton Grange & ... 10,000 & Haversham Grange & ... 11,200 \\
\hline Elstree Grange & $\ldots 6,000$ & *Everton Grange & ... 11,000 \\
\hline Royston Grange & $\ldots \quad 6,400$ & Southern Cross & $\ldots 7,300$ \\
\hline
\end{tabular}

giving a total of 105, 740 tons.

It is interesting to compare the smallest vessel, the Ovingdean Grange, with the largest and most recent, the Everton Grange, the difference being not only in the increased size but also in the great improvements in the propelling machinery, refrigerating machinery, passenger accommodation, appliances for handling eargo and other points too numerous to mention in detail :-

LeNGth. BeAM. DEPTH. ToNs.

Ovingdean Grange... $309 \mathrm{ft} . \quad \ldots \quad 40 \mathrm{ft} . \quad \ldots \quad 21 \mathrm{ft} .4 \mathrm{in} . \quad \ldots \quad 3,520$

Everton Grange $\ldots 490 \mathrm{ft}$. $\quad \ldots \quad 56 \mathrm{ft}$. $\quad \ldots \quad 35 \mathrm{ft} .6 \mathrm{in} . \quad \ldots \quad 11,000$

Special provision has been made for the Company's passenger service, the boats being provided with every requisite to make a long sea voyage as comfortable as possible.

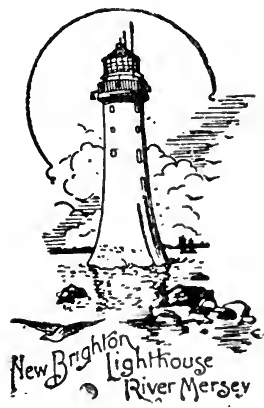




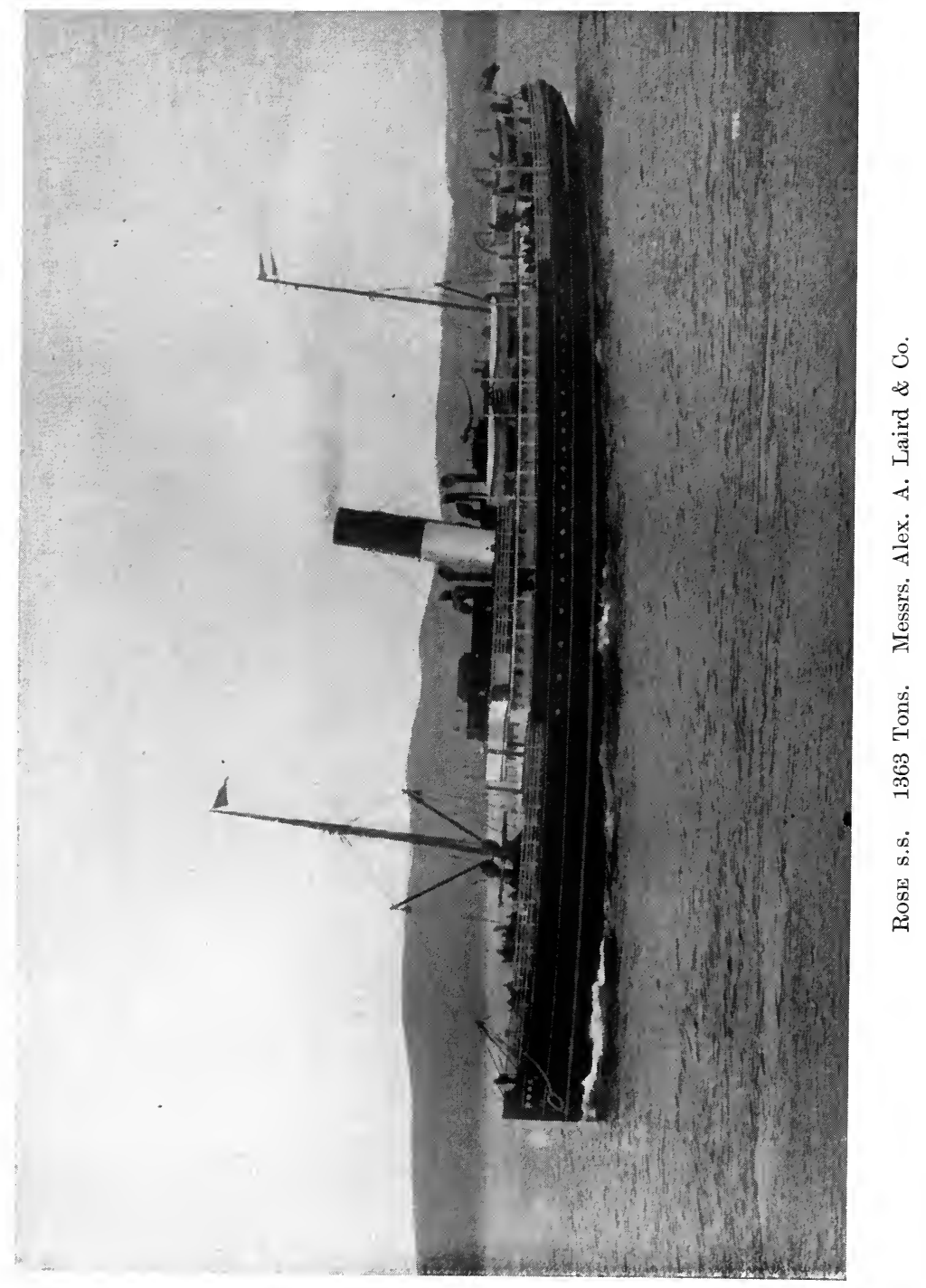


Cinapter Xil.

\section{A IR D L INE.}

\section{THE GLASGOW, DUBLIN, AND LONDONDERRY STEAM PACKET CO., LTD.}

This important eompany, which claims (on very strong evidence) to be the oldest steamship company in the world, was originated in 1814-two years after the launch of Bell's Comet-by Mr. Lewis MacLellan and others. Its history is a most varied one, the several firms of Alex. A. Laird \& Sons, Thos. Cameron \& Co., and MacConnell \& Laird, having become unified during its existence of nearly a century into the one large coneern known throughout the kingdom as the "Laird Line."

It has been the great pioneer of the steamship trade of the Clyde, not merely by reason of its long standing, but also because of the varied and extensive sphere of its operations.

The first steamer owned by the founder of the company was the Britanxia, a small paddle-wheel steampacket, built, like all the vessels of her time, of wood.

The second steampacket was the WaterLoo, built in 1816 . A reference is made to both these steamers in the sixth chapter of the first part of this volume. They plied between the Bromielaw (Glasgow) and Greenock, Gourock, Rothesay, Tarbert, Lochgilphead, and Inverary. Even in these early days of steam navigation, it was the arowed policy of the manager of these steampackets to make all things subordinate to safety, and, in aecordance with this policy, the masters of the steamers were instructed "not to contend with other boats so as to endanger the vessels, or alarm the passengers." This sound policy, whieh has been continued by Mr. MacLellan's suceessors to the present day, has, in large measure, contributed to the popularity and suecess of the firm. 
It is interesting to note that over eighty years ago passenger season tickets were in force on the steampackets of this company. Those who are desirous of verifying this statement can do so by referring to the "Glasgow Chronicle" of the 23rd May, 1816, in which they will find the following advertisement: -

"The steampackets, Britannia and WATERloo, sail

" regularly from the Bromielaw to all the watering-places

" on both sides of the Clyde. Families wishing to agree

"for the season will learn the terms by applying to the

"masters on board, or to Mr. Lewis MacLellan,

"Gallowgate."

The Britannia, in the year referred to, opened up for the first time, steam communication between Glasgow and Campbeltown, and in the early summer of 1820 , she made her first trip from Glasgow to the Giant's Causeway.

She was commanded on that voyage by Captain Wyse, whose death in 1851 was the occasion of the following paragraph, which appeared in the "Glasgow Chronicle" :-

"Captain Wyse (whose decease we announce) was the "first to carry his steamer, the Britannia, on a pleasure " trip from the Clyde to the Giant's Causeway, with an "illustrious and distinguished party. The astonished " inhabitants in thousands crowded the hills and promon"tories, all along the shores of Antrim, to see a ship with " a smoking funnel, and a band of music on board, sailing " against wind and tide. Out of this pleasure trip sprung " up the present lucrative trade between the ports of the "Clyde and the North of Ireland, from which great advan"tages have unquestionably arisen to the inhabitants of "both kingdoms."

As time advanced, the river traffic was discontinued by the Company, and the cross-channel trade developed. After running excursions to the Giant's Causeway for two seasons, the Britannia was placed on the Glasgow and Londonderry station, sailing from each port once a week.

Mr. Alex. A. Laird (after whom the line is named) was a well-known shipbroker in Greenock at the beginning of the last 
century, and when the famous St. George Steam Packet Company commenced operations in 1822, the first steamship service it established was between Liverpool and Greenock, and $\mathrm{Mr}$. Laird was appointed agent for the Company at the latter port.

The St. George Company did not continue for any length of time its direct service between the Clyde and the Mersey, but in the following year (1823) a new steam packet company was formed, to trade only between Liverpool, Greenock and Glasgow, calling at Douglas (Isle of Man) and Portpatrick. Mr. Laird was the manager of the new company, and opened a branch office at 25, York Street, Glasgow, under the style of Alex. Laird \& Co.

The pioneer steamer of the new service was the Hexry BeLL, built by Mr. Thomas Wilson, a celebrated Liverpool shipbuilder, in 1823. She was considered a very smart craft in those days, was fitted with two engines of 30 horse power each, and carried about 120 tons all told, on a draft of about 8 feet. She continued on the Glasgow and Liverpool station until 1831, when she was purchased by Messrs. James Little \& Co., for their Glasgow and Newry trade.

The original intention of the proprietors was that the Henry BeLl should sail to and from Glasgow, but it was found there was not sufficient water in the Clyde to enable this to be done with regularity, and Greenock was, consequently, made the port of arrival and departure. The deck fare by this steamer was $6 \mathrm{~s}$. per passenger, the steerage fare by the mail packets (Majestic and City of Glasgow) being 21 s.

The late Mr. Alex. A. Laird commenced his apprenticeship under his father in 1824, and the same year a second ressel, the JAMEs WATT, was placed on the Glasgow and Liverpool station. She was slightly larger, and had engines of greater power than the Henry BeLL.

The following year Messrs. Laird established a fortnightly service between Glasgow and Inverness; the steampacket employed was the Stirlixg, which made her first voyage on the 11th May, 1825, and continued to sail thereafter on alternate Wednesdays from Glasgow and Inverness. Fortuightly 
sailings proving insufficient for the traffic, the sailings were increased to weekly on and from the 20th September, 1826.

During this year the WILLIAM Huskissor was added to the Liverpool and Glasgow service, and sailings were maintained three times per week from each port.

The WiLliay Huskissox was a very much larger vessel than either of her predecessors, her deadweight capacity being 350 tons, and her engines 120 horse power.

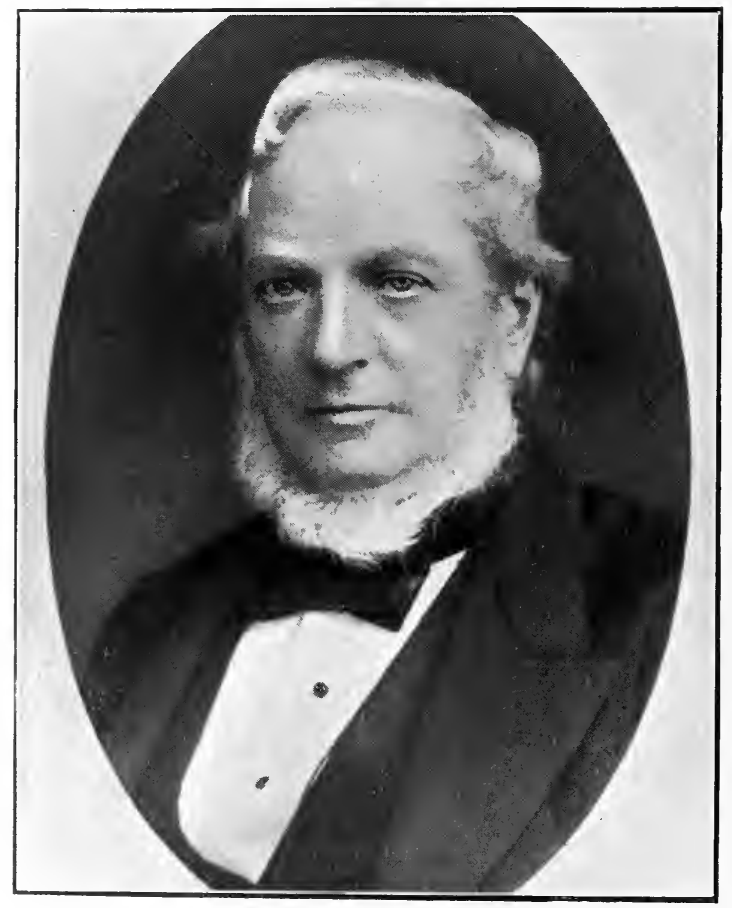

The late Mr. Alex. A. Laird.

For the Campbeltown and Londonderry trade the steampackets Clydesmale and Londonderry were built, and were advertised to sail from Glasgow to both ports, with goods and passengers, every Tuesday, Thursday and Saturday. In addition to these sailings, the MAID of IsLAY was despatched every Tuesday morning from the Bromielaw to Stranraer and 
Islay. Messrs. Laird's comnection with Dublin dates also from this year, the pioneer steamer being the Tow of I)roghris, which sailed on her first voyage from Greenock to Dublin on Monday, 7 th June, 1826. The new steampacket Solway was added to the Liverpool and Greenock fleet in 1828, and the sailings increased to four per week from each port. The steampacket Clarexce acted as tender, and sailed from the Bromielaw at noon on the sailing dates of the Liverpool steampackets from Greenock.

In 1834 the firm extended its operations to Newry, the steamers employed being the ErIs and ST. DAvid. Mr. James Bruce was admitted a partner in the Glasgow house this year, and the office was removed to 69, Oswald Street, where the business was conducted under the style of Laird \& Bruce. This partnership was dissolved on the 14th February, 1835; Mr. Bruce retaining the Stranraer trade. The title of Mr. Laird's firm was changed to Alex. Laird \& Sons, and the Glasgow office removed to Ewing Place, corner of York Street.

One of the steamers, for which Mr. Laird was agent, was named the Cumberland. This vessel took an active part in the Spanish Expedition of 1835, as a transport, making three voyages to Spain during this year, with recruits from the West of Scotland for the service of Donna Isabella. Some of these recruits enlisted in the course of drunken frolics, or after quarrels with their friends or masters, and their military ardour speedily cooled. The period during which they had to wait on the receiving ship at Greenock until the transport was ready to receive them afforded frequent opportunities of deserting, of which they did not fail to avail themselves. Scarcely a day passed but some of them succeeded in escaping by means of the boats which visited the receiving ships in the evenings. One youth from Glasgow, failing to get away in this manner, determined to drop into the sea and swim ashore, a distance of about two miles, to a spit where female friends would be waiting to assist him. He had nearly reached the shore when he was discovered, and pursued by the guard boat. Making a final effort, he succeeded in landing, and, though fatigued with his long swim, continued his flight. 
When the guard boat's crew landed, the women got round them, and so hampered them in their movements that the fugitive got out of sight, when, of course, it was useless to attempt to follow him.

The Cumbertand, after performing the three voyages referred to, returned to her station between Glasgow and Dublin.

In 1844 Messrs. Laird \& Sons (then at 101, Union Street) were appointed agents at Glasgow for the Dundalk Steam Packet Co., the first steamer from Glasgow, the Fins Maccoul, sailing on the 30th November, 1844.

For a period of forty years, from 1827 to 1867 , Messrs. 'T. Cameron \& Co. had maintained steamship services between Glasgow and Greenock, and ports on the North and West coasts of Ireland, and from 1843 until 1867 a weekly service between Liverpool and Sligo. In 1867 the Glasgow services were conducted by the joint firms of Messrs. T. Cameron \& Co. and Alex. A. Laird \& $\mathrm{C}_{\text {?. }}$, but the following year, owing to the decease of Mr. Cameron, the business was entirely taken over by Messrs. Laird.

Messr's. Cameron's steamers were named after flowers and plants (with two exceptions, referred to later), the first steamer of this class being the Sнamrock, built in 1847 , followed by the Thistle in 1848, Rose in 1851, Mrrtle in 1854, and the Garland in 1857.

At the time of the change of firm, Messr's. Cameron \& Co. had been opposed on the Glasgow and Sligo and Liverpool and Sligo stations, for ten years, by a local company, the Sligo Steam Navigation Co. This was subsequently settled amicably, Messrs. Alex. A. Laird \& Co. retired from the Liverpool and Sligo trade, and the Sligo Steam Navigation Co. withdrew from the Glasgow trade, and having purchased the opposition steamer Garland, renamed her the GlasGow.

The two exceptions in class of name, to which reference has been made, were the Nortuman and Irishman, trading as the Glasgow and Dublin Screw Steam Packet Co. They were amongst the earliest iron screw steamers built, the former having been launched in 1847 and the latter in 1854. These 
two steamers retained the colour of the old St. George Co. on the funnel, viz., a white funnel with a black top. The IrisuMAN was the last steamer so distinguished, all succeeding steamers carrying what is now the recognised "Laird" funnelwhite and red in equal proportions, with a black top.

In 1869, to meet the requirements of the West Coast of Ireland trade, the Company purchased the steamer Scotis, and renamed her the LAdrex. Two steamers were added to the fleet in 1878. These were the steamships Azalea and Cendr. These ships are identical in measurement and capacity, each being 217 feet long, 30 feet broad, and 15 feet deep, with a gross register of 750 tons, and with excellent saloon accommodation for seventy passengers.

An important addition was made to the fleet in 1879 , when the magnificent and fast steamship Sнамrock was built. She was considerably in advance in point of capacity, speed, and accommodation of any steamer previously built for the firm. She measures 231 feet 2 inches in length, 31 feet 3 inches in breadth, and 15 feet 5 inches in depth; and her gross register is 864 tons. She is certified to carry eighty saloon passengers, and is equipped with every modern convenience for their comfort.

After an interval of three years (1882) the Brier was built, a somewhat similar vessel, but slightly smaller than the preceding steamer, her dimensions being 209 feet by 30 feet by 15 feet. Her gross register is 728 tons, and she has berthing and saloon accommodation for sixty passengers. She was quickly followed by the Thistue and Elm, both built in 1884, and the Gardenia in 1885. They are all beautiful specimens of marine architecture, the first a large steamer of 822 tons gross register, and the latter considerably smaller.

In 1893 a further advance was made in the size of the Company's ships by the construction of the splendid screw steamer OLIve, 1,141 tons gross register, one of the fastest anci finest steamers crossing the channel. She is 260 feet long, with a beam of 33 feet 1 inch, and a depth of 15 feet 8 inches. She has always been a particular favourite with passengers, of whom she carries a large number, being certified to carry one hundred saloon passengers, in addition to 1,000 steerage. 


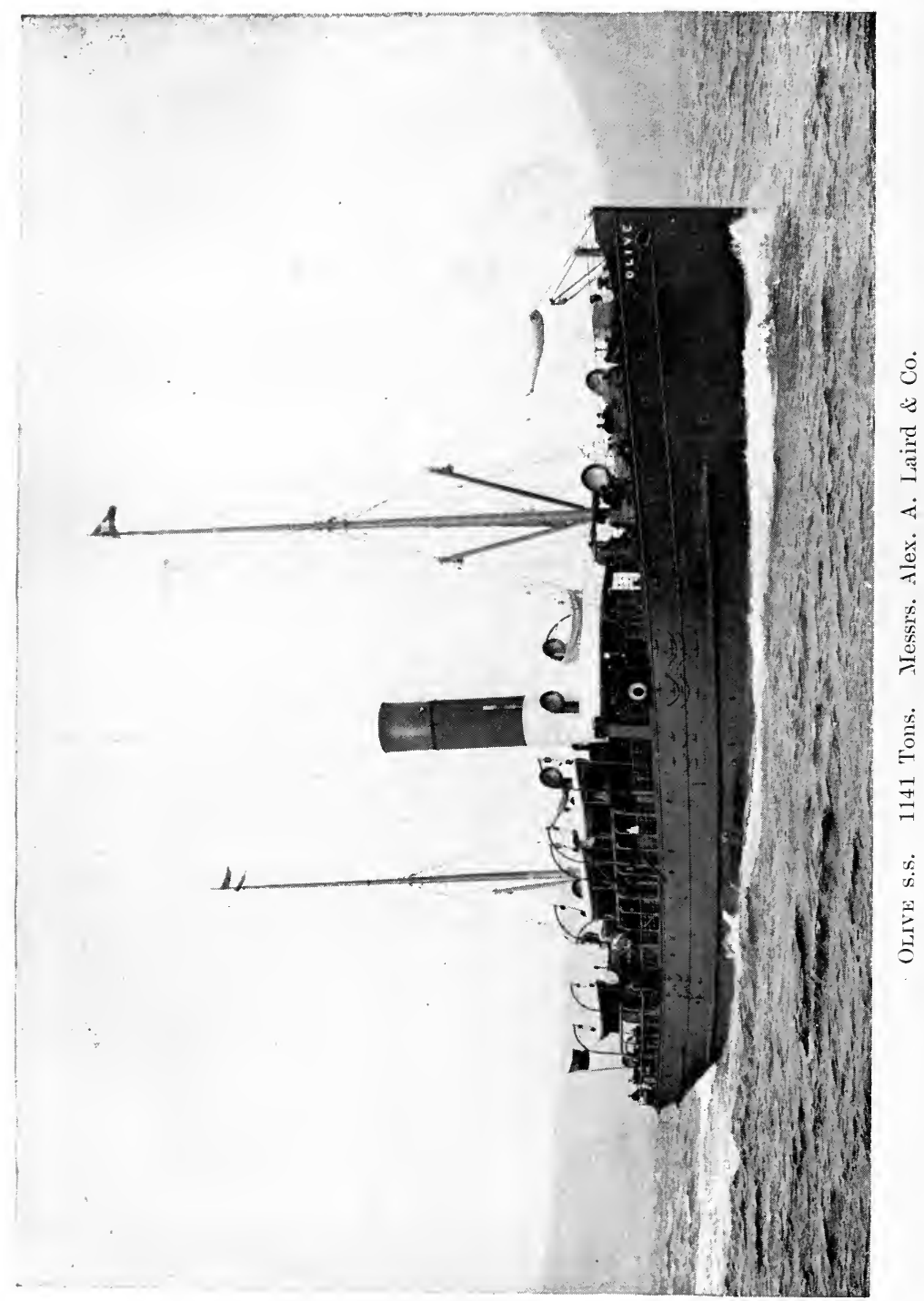


The DAIsy and the LiLy were the next steamers built, the former in 1895, and the latter in 1896; and in the closing year of the nineteenth century the FERN (second of the name) was launched.

The latest addition to the fleet is a magnificent vessel constructed after the most modern type of passenger steamships. She is named the Rose, was launched in June, 1902, is built of steel, and is 250 feet long, 36 feet 2 inches broad, and 15 feet deep. She is fitted with electric light in the saloon, staterooms and holds. Her saloon, which is a handsomely furnished and spacious apartment, is situated amidships forward of the engine room. The great breadth of the vessel makes her a remarkably steady sea boat, while her engines, which are triple-expansion and of great power, are capable of propelling her at the rate of $15 \frac{1}{2}$ knots per hour. She is nearly 1,400 tons gross, and carries 140 saloon passengers, in addition to those in the steerage.

In 1885 it was considered desirable to consolidate the several interests concerned, by forming this old-established business into a limited company, the title of the Company being The Glasgow, Dublin and Londonderry Steam Packet Co., Limited; but it is much better known by the short name of the "Laird Line." Mr. William MacConnell, son of the late Mr. MacConnell, of the firm of Thomson \& MacConnell, is the Managing Director.

The company's steamship services are not confined to those to and from Glasgow, although we have shown that they have a very large share of the Clyde traffic, maintaining regular and frequent sailings between Glasgow and Greenock and Dublin, Londonderry, Coleraine, Sligo, Ballina and Westport; also during the tourist season a daily daylight service between Ardrossan and Portrush.

In connection with the Midland Railway Company of England a service of powerful steamers is maintained between Morecambe and Dublin, the steamers sailing from the respective ports on alternate days, and making the passage in about 10 hours.

Early next year, it is proposed to transfer the service from 
Morecambe to Heysham, and to maintain daily sailings to and from the latter port and Dublin.

The "Laird" steamers also sail in connection with the same railway company from Norecambe to Londonderry every Thesday and Saturday, returning from Londonderry every Monday and Thursday.

From Fleetwood, in connection with the Lancashire and Yorkshire, and London and North-Western Railway Companies, a weekly service had been maintained for many years by the company's steamers between Fleetwood and Londonderry, but in September, 1903, Messrs. Laird \& Co. retired from this service.

From Liverpool also, steam communication is maintained with Larne, Coleraine and Westport. The fixed sailings are once a week from each port, but extra steamers are despatched according to the requirements of the trade.

The company's fleet at the present date (1903) consists of 12 first-class powerful steamships, having an aggregate gross tomnage of 9,164 tons, and named as follows:-

\begin{tabular}{|c|c|c|c|c|}
\hline \multicolumn{2}{|c|}{ Gross Tonnage. } & \multicolumn{2}{|c|}{ Gross Tonnage. } & Gross Tonnage. \\
\hline AzALEA ......... & 748 & Elm .............. & 521 & Olive............ 1141 \\
\hline Brier............ & 728 & Ferr.............. & 503 & Rose... \\
\hline Cendar ........... & 750 & Gardenia ..... & 491 & Sнамвоск....... 864 \\
\hline DaISY............. & 565 & LILY............... & 668 & Thistle......... 822 \\
\hline
\end{tabular}

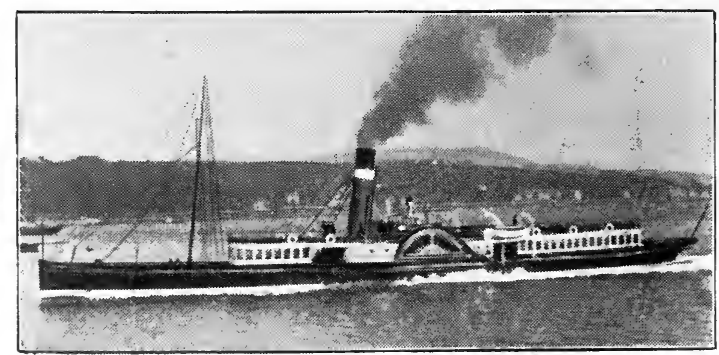




\section{Ghapter XIII.}

\section{LANGLANDS' LINE.}

\section{GLASGOW AND LIVERPOOL ROYAL STEAMPACKET COMPANY.}

Prion to the year 1839 all the steampackets plying between Liverpool and Glasgow were built of wood, and these wooden steamers had established for themselves a reputation for speed and luxurious travelling not surpassed nearly threequarters of a century later. It was, therefore, a bold thing to do on the part of the proprietors of the Glasgow and Liverpool Royal Steampacket Company to enter into competition with these famous and tried vessels, and to introduce into the trade steamers constructed not of wood but of iron. The pioneer steamer of this company, the Roral Soverwicis, sailed on her maiden voyage from Liverpool on Monday, 18th March, 1839. The company despatched their steamer twice a week from each port, and continued to do so until the end of August of the same year, when the second steamer, the Royal George, was placed on the station, and the sailings were increased to four times per week each way. The established lines were naturally indisposed to share the trade with an outsider, and to discourage the new enterprise they reduced the rates of freight on fine goods to $1 \mathrm{~d}$. per foot, and on steerage passengers to $1 \mathrm{~s}$. each. 'The Royal Steampacket Company maintained, in spite of this endeavour to drive them out of the trade, their advertised sailings, and grew in popularity with the travelling public. They decided in 1841 to increase their fleet by the addition of a third steamer, and it being evident that they had come to stay, their competitors, Messrs. MacIver and Messrs. Burns, entered into a 


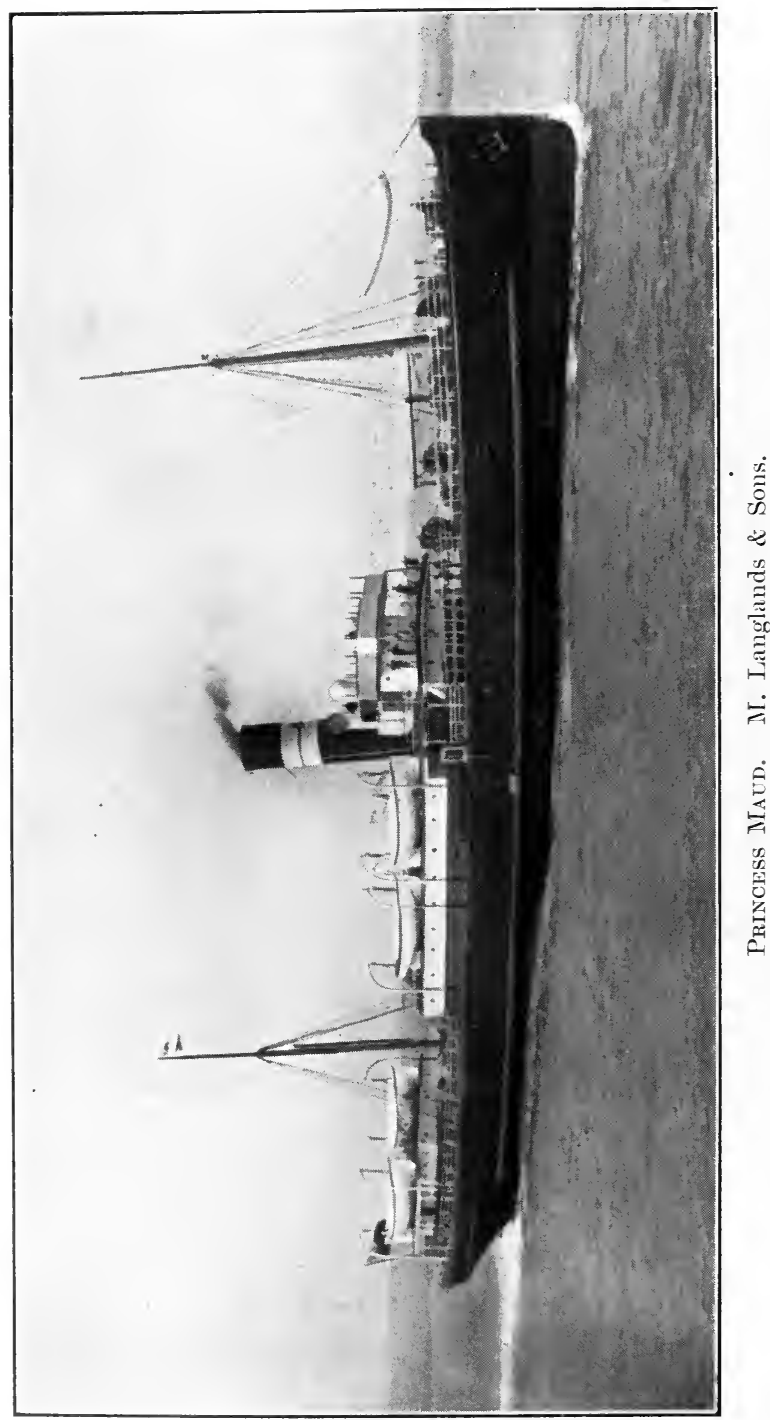


friendly and honourable alliance with them, and uniform rates were adopted by the three lines to Glasgow.

A tradition exists in the Royal Company that when their third steamer was on the stocks the first birth in her late Majesty's family was anticipated, and the proprietors proposed to eall their new steamer the Prixce of Watrs. The event, however, proved the name to be inappropriate, and Prixcess Royal was substituted, a name which has been perpetuated by different steamships to the present day. The following paragraph respeeting this steamer, which appeared in the "Glasgow Chronicle" of the 1st June, 1842, will be read with interest:-_" The Princess Rorat. We feel much indebted to the agent (Mr. M. Langlands) of this splendid steamer for putting us in possession of the 'Morning Chronicle' of yesterday morning three hours before the arrival of the 'London Mail' containing the details of the attempted assassination of Her Majesty. Copies of the 'Chronicle,' 'Times,' and other London journals were, the moment the train arrived from Greenock, forwarded to the different public reading rooms in town, and altogether the public are much indebted to the proprietors and agents of the vessel at Liverpool and Glasgow for their public spirit and enterprise. The passage from Liverpool to Greenoek was made in the astonishing space of $16 \frac{1}{2}$ hours."

The Prixcess Royal referred to was built by the eminent firm of Tod and M'Gregor, who in 1849 projected a line of steamers to run between Glasgow and New York. Accordingly they built and equipped the barque-rigged screw steamer City of Glasgow, and appointed Mr. M. Langlands agent. She was a vessel of 1,087 tons register, with engines of 350 horse-power, and was manned by about 70 of a crew. In the Art Palace at Kelvingrove, Glasgow, there is a watercolour drawing (No. 2,018, by S. Bough) representing the departure of this the first steamship for New York from Glasgow harbour, in April, 1850. After making several very successful voyages, Tod and M'Gregor sold her to Richardson Bros., of Belfast, who ran her in the Liverpool and Philadelphia trade, and this ressel and the steamship Citr or 


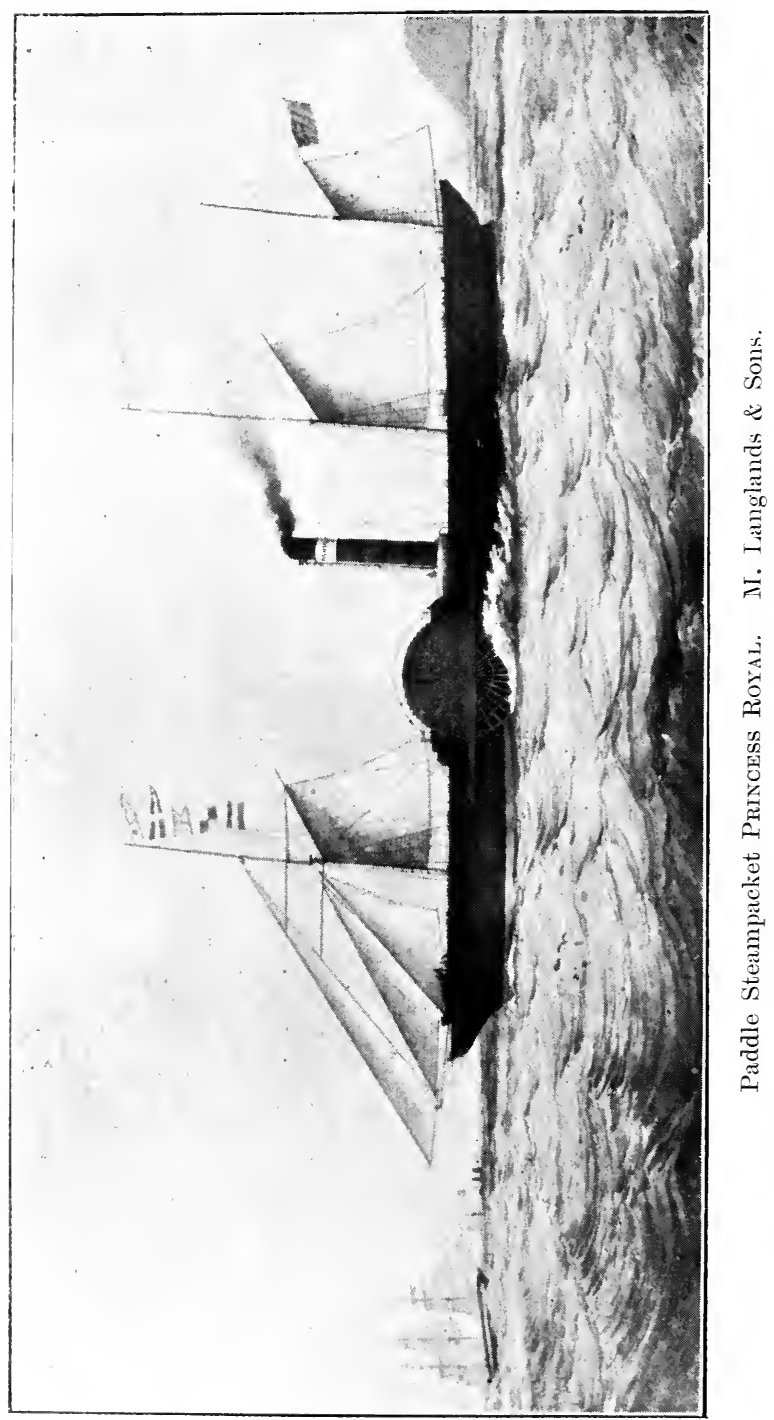


Manchester were the nucleus of what became afterwards the well-known Inman line.

In view of the high reputation the Princess Rorat had earned, it is not surprising that she was selected for experimental purposes by a Committee of the IIouse of Commons (appointed in 1842) for the purpose of inquiring into the eonveyance of the mails between England and Irelaud. From the "Liverpool Mereury" of that date we learn that "The fine new iron steamboat ealled Prixcess Royal, at present on the station between this port and Glasgow, started from Clarence Dock on Sunday morning last (19th June) for Dublin. She arrived there in 9 hours 5 minutes, beating H.M. mail steampacket Medusa by 1 hour 45 minutes. On Monday morning she left Dublin for Ilolyhead, and arrived there in 4 hours 45 minutes, returning to Dublin the same day in 4 hours 28 minutes. In the evening she started for Liverpool, which she reached in 9 hours 35 minutes. The vessel had a head wind nearly all the way."

The Princess had now established beyond dispute her claim to be one of the fastest Channel steamer's leaving the port. The ensuing winter she proverl herself to be also one of the best sea-boats. The terrible gale of January 20th to 22nd, 1843, was one of the most severe that ever visited these coasts. The Mora's IsLe, from Liverpool to Douglas, was 'Dt hours on the passage. At Cork the posts on the quays were carried away. The PrIncess was at sea during this storm, and fully proved her excellent qualities as a sea-boat. She left Greenock at 11-30 p.m. on Friday, and arrived at Liverpool at 5 p.m. on Saturday without the slightest damage. This celebrated steamer was replaced in 1856 by a second Princess Royal, also a paddle steamer. After rumning in the Liverpool and Glasgow service for about four years, Princess No. 2 was sold to the General Steam Navigation Company, of London.

The third Princess Royal, built in 1861, was a screw steamer, the first serew owned by the Glasgow and Liverpool Royal Steampacket Company. In 1861, eivil war broke out in the United States. The Federals (Northerners) established 
a strict blockade of all the Southern ports on the Atlantic seaboard. A cotton famine ensued, and fast steamers were in great demand for blockade running. Amongst other Liverpool steamers purchased for this purpose was the new Princess. She was sold in 1862, and her new owners changed her name. We are informed that she was captured on her first trip as a Confederate blockade runner, and converted by her captors into a Federal cruiser. Her immediate successor, the fourth Prixcess Royal, after running for a number of years between Liverpool and Glasgow, was sold to a firm to trade in the West Indies. For the present the Royal Steampacket Company is without a Prixcess Royal, the fifth steamer of that name having been sold in 1901 to foreign buyers. The service is meantime maintained by the Princess Louise, or other steamer of the fleet.

About the year 18r0, the Royal Company opened up a new steamship service from Liverpool to the West Highlands, North of Scotland, and east coast ports. Owing, in large measure, to the natural attractions of the route, and the excellence of the accommodation and cuisine provided on the steamers, this is every year becoming a more popular and favourite trip. The first steamer employed on the West Highland and east coast route was a small cargo steamer, but in a very short time it was found necessary to place the Princess Alice, a much larger steamer, carrying passengers as well as cargo, on the route. The earlier vessels on this service were steamers of 300 to 400 tons, with limited accommodation for about 20 passengers, but now the steamers employed have accommodation for 100 to 140 saloon passengers, and an average cargo-carrying capacity of nearly 1,000 tons each. Some idea may be gained of the growth of the passenger and cargo traffic, by comparing the earlier vessels with the new Princess Maud, built in 1901. This steamer is of steel, and her dimensions are:-Length, 256 feet 6 inches; breadth, 36 feet 6 inches; depth, 17 feet $1 \frac{1}{2}$ inches. Gross tonnage, 1,450 tons. The vessel is handsomely fitted up for passengers, the large dining saloon being furnished in solid oak, artistically carved. One hundred first-class passengers 
can dine at one sitting, and there is sleeping accommodation in deck rooms and state cabins for 140 passengers. The steamer is fitted throughout with electric light, patent berths, sea-water baths, ample lavatories, and every modern convenience that can contribute to the comfort of passengers. The Princess Maud was placed on the service early in 1902, and will no doubt enhance the reputation in which this line is held by tourists. In addition to the bi-weekly service between Liverpool and Aberdeen, Leith, and Dundee, the Royal Steampacket Company run a regular service of steamers between Aberdeen, Newcastle, Hull, and other east coast ports, and Bristol, Cardiff, and Swansea, calling also at Southampton and Plymouth. During the summer months this service embraces a fortnightly trip round the United Kingdom with one of the larger passenger steamers, and this has now become a favourite cruise for summer holiday seekers, occupying as it does about twelve days.

When the Manchester Ship Canal was opened in 1894, the Royal Company began at once to despatch their steamers from Manchester to Glasgow, as well as to the west, north, and east coasts of Scotland. In addition to having the management of the various services mentioned, Messis. Langlands have, for a great many years, been the agents of Messrs. Alex. A. Laird and Co. as regards the steamers trading between Liverpool, Larne, and Westport.

The agency of the company's steamers at Glasgow, Liverpool, Manchester, Leith, Dundee and Hull, is in the hands of Messrs. M. Langlands and Sons, who have been closely identified with the development of the company's business, and are largely interested in its success.

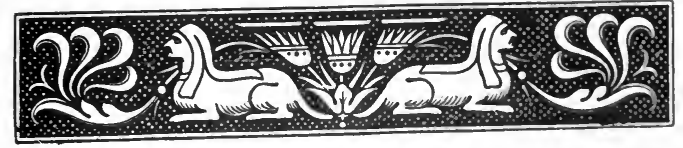


Cinapter XIV.

\section{MESSRS. JAMES LITTLE \& CO.}

T'owards the end of July, 1819, Messrs. James Little \& Co., who had commenced business seven years previously, despatched from Greenock, on her maiden voyage to Liverpool, the first passenger steamer that ever sailed from the Clyde to the Mersey. Her name was the Robert Bruce, and she was described in her advertisements as bəing "an elegant new Steam Packet, having most excellent accommodation for passengers." As a matter of fact, she was a small wooden paddle steamer, 98 feet long, or about twelve feet longer than the Cluthas that ply up and down Glasgow Harbour, but with twice their beam. She called at Portpatrick and Douglas (I. of M.) on her voyages to and from the Clyde, and occupied about thirty hours on the run from Greenock to Liverpool. The following letter from the Captain (Patterson) to Messrs. Little, written on the 1st September, 1819, indicates how different are the conditions under which passengers travel by steamers at the present date and those which existed in the early stages of steam navigation. Captain Patterson dated his letter from Troon, and stated:-

"I have to inform you that we were taken with a heavy " gale of wind from the N.W. yesterday about two o'clock, just " as we had got outside the Cumbraes, with a heavy sea; about "six o'clock the sea came more to the westward, and, from the "very heavy sea on our beam, we made, so much lee-way that "we could not stand out-channel nor fetch Lamlash. I, there" fore, thought it best to bear up for this port, and got in safe "last night with the loss of our bowsprit, but no other damage. "Our engines worked very well, only the wheels had little 
" effect owing to the heavy sea. It has continued to blow a "gale all night, and still looks very bad. The ship Nereus "got here an hour before us, dismasted. I will get another" "bowsprit as soon as possible, and will proceed when it "moderates. The passengers were all sick, but are now well.

$$
\begin{aligned}
& \text { "I am, \&c., } \\
& \text { "John Pattersox. }
\end{aligned}
$$

"P.S.-The Robert Bruce behaved under her sails, "double reefed, as well as any ship I was ever in."

The rates of passage money were:--Cabin, 40s.; steerage. 21s. A second steamer, the Superb, was placed on the station during the same season, and in 1820 a larger steamer, the Majestic, was added to the service.

An interesting and valuable painting of the latter steamer in 1820 is in the possession of Messrs. Little \& Co., at their office, 46, Leadenhall Street, London.

A curious intimation appears in the Glasgow papers of the 19th July, 1822, with reference to the same vessel. It appears that on a recent trip the Duke of Athol and suite had embarked on board the MAJESTIC at Greenock, for conveyance to Douglas (I. of M.), where his Grace had a seat (Mona Castle). As well as being accompanied by the members of his suite, His Grace had with him several carriages and a quantity of luggage, all of which took some time to land. Some of the Liverpool passengers complained of the detention of the steampacket for this purpose, and, on the complaint being submitted to the managers of the steamer, they not only expressed their regret for the delay, but they also donated the amount of freight they received from the Duke of $\Lambda$ thol to the fund for the relief of the starving Irish.

A fourth steamer, the City of GLasGow, was added to the fleet on the 21st June, 1822. The Roвent Briç having beeome too small for the Greenoek and Liverpool service was transferred to the Liverpool and Douglas station, and the three larger steamers were appointed to carry H.M. mails to and from Greenock and Liverpool. The wretehed condition of the destitute poor in Ireland was not the ouly 
charity that appealed to the managers of these steamers. Finding that the Committee of the Greenock Hospital and Infirmary were in urgent need of funds, they placed the R.M.S. City of GlasGow at the Committee's disposal for one day, for the benefit of the Institution named. The Committee of Management of the Hospital accordingly arranged a cruise per that steamer around Ailsa Craig, on Saturday, 19th July, 1823, tickets for which were 7s. 6d. each. The Ciтy of Glasgow continued to trade between Greenock and Liverpool until 18:31, when she was purchased by the late David MacIver, who was then forming the City of Glasgow Steam Packet Co. Although Messrs. Little's connection with Belfast is not of such long standing as with Liverpool, yet it is approaching three-quarters of a century. In January, 1828, the new steamer FroLIc began to trade between Glasgow, Greenock and Belfast. She differed from the steamers of the Liverpool route in carrying cargo as well as passengers. The previous year, Messrs. Little had obtained the agency in Greenock of the Glasgow and Dublin Shipping Company. The pioneer steamer of this line was the Erix, which sailed from the Clyde on her first voyage in March, 182\%. A second steamer, the Scotia, a vessel of 300 tons burden, was added to the service in January, 1828. The steamer WATER WITch, built for this trade by Messrs. James Little \& Co., and contracted for with Messrs. Denny \& ('o., of Dumbarton, was the first screw steamer built on the Clyde.

In addition to their several channel steamers, Messrs. Little owned, in 1850, the steamers Dunoov and HeLensвए RGII. These two steamers plied with passengers between Greenock and coast towns, connecting with the Glasgow and Greenock Railway (now the Caledonian Railway), and they were the first steamers on the Clyde to run in comnection with a Railway Company.

In 1872 this firm purchased from the owners of the Anchor Line steamers the steamer Dom PEDro, a screw steamer engaged in the Glasgow and Peninsular service. The Dом PEDro was the first screw steamer with compound engines, 
built by the famous Clyde shipbuilding firm, Randolph and Elder, now known as the Fairfield Shipbuilding Co. Subsequently, Messrs. James Little \& Co. owned a fleet of steamers bearing Greek classical names, e.g., Apomro, Achilles, \&c., and to be in accordance with these the name of the Doss Penro was changed to the Ariannf in the year 1875 . She has now for a number of years been running on the Barrow and Liverpool station. In the year 1866, Messrs. Little ran the paddle steamer Herati between Glasgow and Campbeltown. The Heraid proved herself when on the Campbeltown route to be one of the fastest, if not the fastest, steamer on the Clyde. She was withdrawn the following summer (186r) from the Glasgow and Campbeltown station, to open the Barrow and Isle of Man trade. The latter traffic is now maintained during the summer months by the magnificent steamers, Maxx Queen, Duchess of Devoxsinte, or Duchess of Buccletch. The Maxx Queex is a large steel paddle steamer, with a gross register tonnage of about 1,000 tons, built and engined on the Clyde by Messrs. J. and G. Thompson. Her principal dimensions are length, 278 feet 9 inches; beam, 29 feet 7 inches; depth, 14 feet, and her speed is about 16 knots per hour.

The Duchess of Devoxshire is a steel twin-screw steamer, built and engined in 1897 by the Naval Construction and Armaments Co., Barrow. Her gross register tonnage is 1,265 tons; her length is 300 feet; beam, 35 feet 1 inch; and depth, 15 feet $\tau$ inches. Her engines are capable of driving her considerably over 18 knots per hour, and she is, therefore, one of the fastest steamers in the cross-channel trade.

The Duchess of Buccleuch is a stcel paddle steamer, with a gross register tonnage of 804 tons, built and engined in 1888 by the Fairfield Shipbuilding and Fingineering Co., Ltd., Glasgow. Her length is 256 feet 1 inch ; beam, 29 feet 1 inch; and depth 14 feet, and her speed is about 18 knots per hour.

The route via Barrow to Douglas gives the shortest sea passage from England to the Isle of Man, the average passage being about three hours. In consequence of this, and of the 
first-class accommodation provided in these splendid steamers, the Barrow route is a favourite one to the Island, and each year sees an increase in the number of passengers carried.

Messrs. James Little $\&$ Co., in conjunction with the Midland and Furness Railways, established, in 1867, a service of mail, passengers and cargo steamers between Barrow and Belfast.

For the conduct of the business connected with this service, Messrs. Little opened a branch office in Belfast, and, as they had also started the Barrow to Douglas trade that same year, they opened an office in Barrow. The first steamers employed on the Barrow and Belfast station were the paddle-steamers Roe, Talbot, and Shelburne. In 1870 a larger and faster paddle-steamer, the Aктrim, was added to the fleet.

The service is now maintained by the swift and powerful Royal Mail Steamships Citr of Belfast, Duchess of Devonshire, Manx Queen or Londonderry. The Duchess of Devorshire has already been briefly described. Her sister vessel in the service, the City of BeLfast, is slightly smaller. Her gross register tonnage is 1,055 tons.

These powerful steamers leave Belfast every evening at 8-30, Irish time, and arrive in Barrow about 6 o'clock on the following morning, in time to connect with the early morning Midland trains to all parts of England and Scotland. The steamers leave Barrow daily (Sundays excepted) on arrival of the through trains from London, Bristol, Leeds, \&c., that is about 8-30 p.m., and arrive in Belfast about 5-30 the following morning (Irish time).

In 1873 Messrs. Little opened a branch office in Glasgow, and in 1883 one in Liverpool. In addition to the mail and other steamship services on the West Coast of Britain, Messrs. James Little \& Co. have a regular service of steamers from London to T'erneuzen, in Iolland, and for the efficient working of this service they, in conjunction with Mr. J. W. Johnston, opened an office in London in 1886, the name and address of the London firm being Little \& Johnston, 46, Leadenhall Street, who also have a sub-office in Terneuzen.

They have also several ocean steamers, not built for any 
special trade, but of large carrying capacity, under the management of their Glasgow house.

The theet of this firm at the present date (190:3) consists of fourteen full-powered steamships, having a gross registered tonnage of 25,279 tons, and named as follows:-

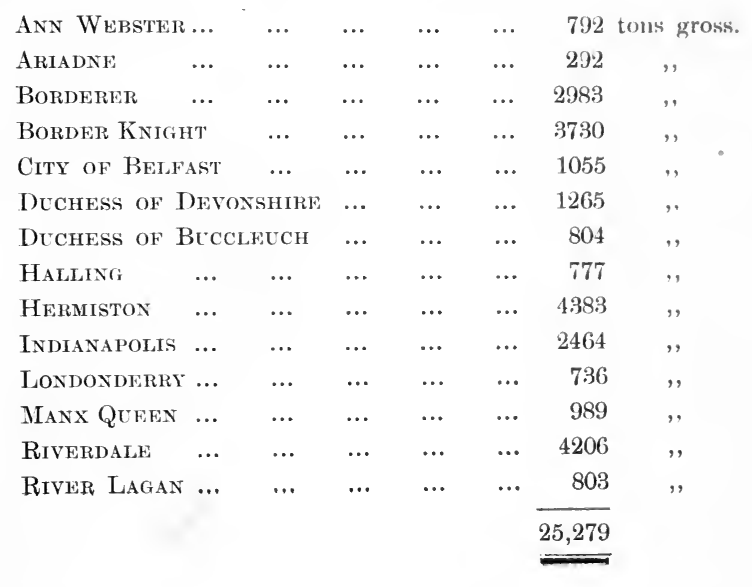

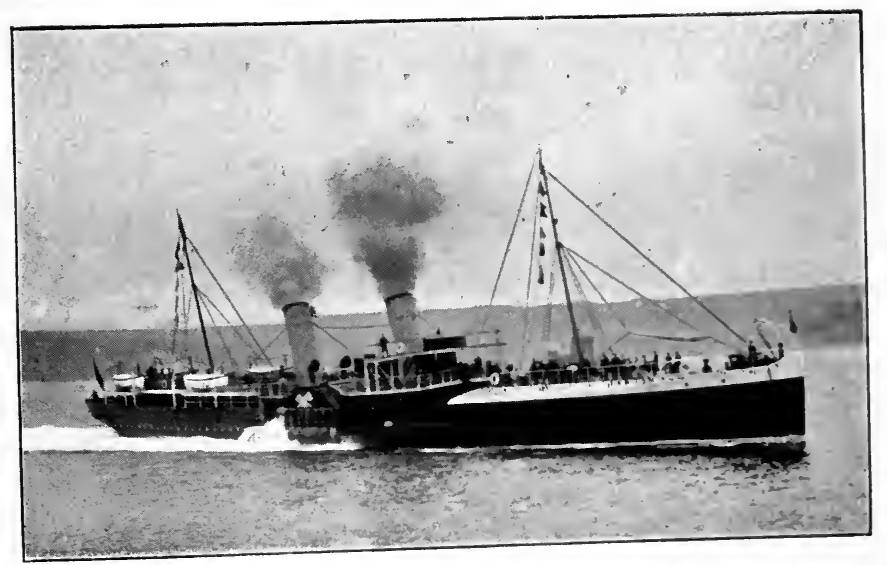

Deculess of Bucchecch. James Little \& Co. 


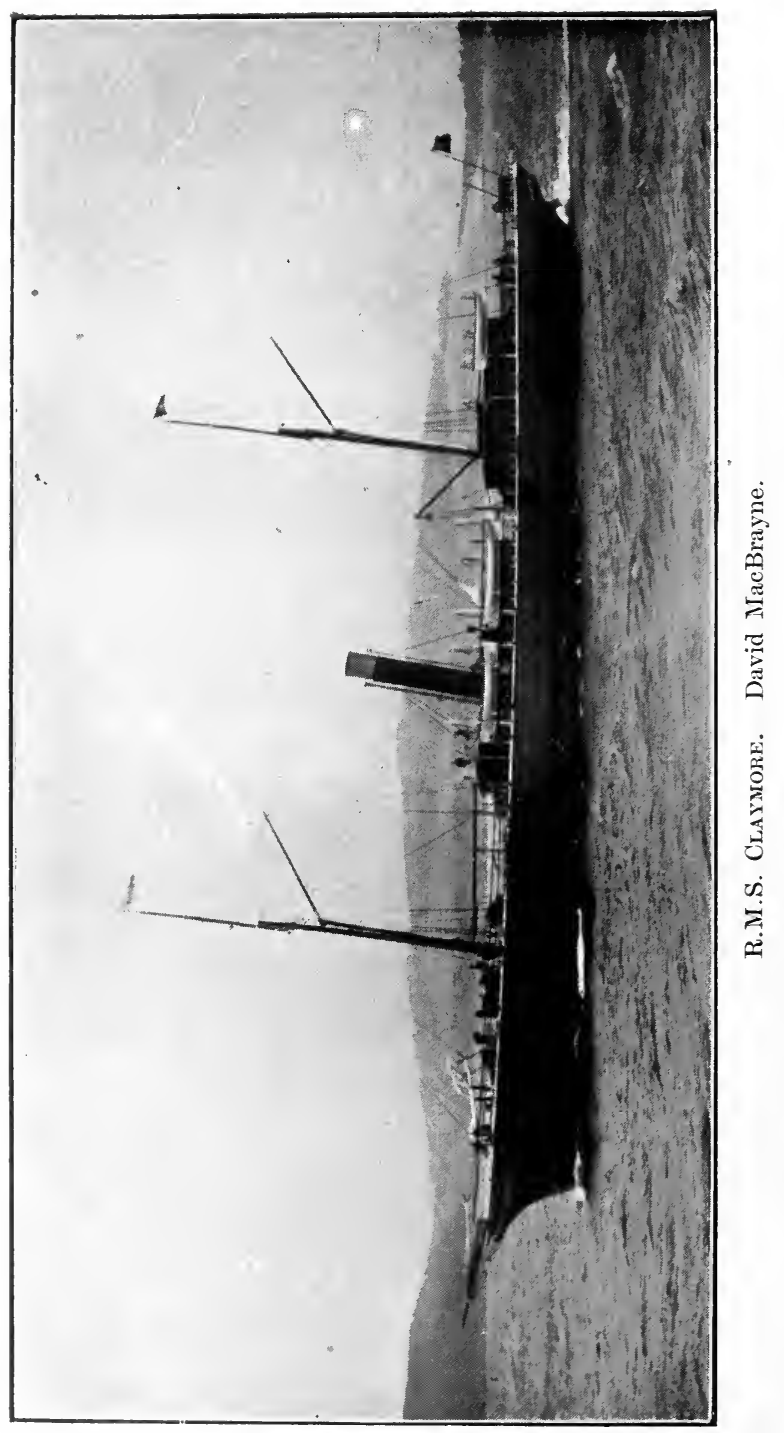


Chapter XV.

\section{MR. DAVID MACBRAYNE'S WEST HIGHLAND STEAMERS.}

Is the early part of last century Messi's. Thomson and MacConnell, of Glasgow, held a large financial interest in several of the steampackets then plying on the River and Firth of Clyde. One of the earliest of these steamers in which they were interested was the Britanxia, built about two years after Bell's Comet. The citizens of Glasgow were quick to avail themselves of the advantages of steam navigation: thus, while in 1812 the limit of steam navigation was Dunoon, in 1815 it was extended to Inverary, and in 1822 Fortwilliam, Tobermory and Skye were included in the ports of call of the steampacket Highlander.

Passengers were also carried by the same steamer to the Island of Staffa, the fare for the return passage being $£ 33$ s.

Steam communication between Glasgow and Inverness via the Crinan and Caledonian Canals was established in the spring of 1824 , the pioneer vessel being a small steamer named the Ben Nevis.

About 1830 Messrs. J. Martin and J. \& G. Burns advertised the steamers Inverness, Rob Roy and Helex McGregor to sail regularly between the Clyde and Inverness, Skye and Stornoway. The Helex McGregor was described as having "a splendid cabin, panelled with landscapes descriptive of the scenery through which she passes." She had upwards of 30 sleeping berths for cabin passengers, and an excellent steerage.

In 1841 the Srrandon, described as " an elegant vessel," was placed, by the same firm, on the route now taken by the R.M.S. Columba. Her passengers were carried tinrough the Crinan Canal on track boats drawn by horsses ridden by postillions in brilliant scarlet uniforms, and at Crinan were 
transferred to the steampacket BRENDA, which conveyed them to Ohan. The latter' steamer belonged to Messrs. Thomson and MacConnell, as did also the Toward Castle, Morven and Staffa, and later (1846) the Edinburgh Castle and Maid of IstaY. The two firms had been engaged in friendly competition both on the Glasgow and Liverpool trade and the Glasgow and West Highland service from the year 1831, but in 1841 an arrangement was arrived at, by which the West Highland traffic was managed conjointly.

Her late Majesty Queen Victoria visited the Highlands in 1847, and in "Leaves from the Journal of Our Life in the Highlands," Her Majesty wrote:-

"The light on the hills was beautiful as we steamed "down Loch Fyne. At five we reached Lochgilp, and all "landed at Lochgilphead (Ardrishaig). We and our "people drove through the village to the Crinan Canal, " where we entered a most magnificently decorated barge, " drawn by three horses ridden by postillions in scarlet. "We glided along very smoothly, and the views of the "hills-the range of Cruachan-were very fine indeed."

To meet the requirements of an ever-increasing traffic, the elegant saloon steamer LinNeT was built, which is capable of comfortably accommodating double the number of passengers that the old track boat could.

The Messrs. Burns, who prior to that date had controlled a large portion of the River Clyde and West Highland traffic, in 1851 decided to confine their energies to "deep sea" steamers, and accordingly sold off their smaller craft, and Messrs. Thomson and MacConnell parted with their steamers of the same type. These vessels were acquired, and the West Highland trade taken over, by Messrs. David Hutcheson \& Co. (the company including Mr. Mavid MacBrayne, the head of the present firm), whose address at that date was 14, Jamaica Street, Glasgow.

Messis. Hutcheson had, previous to the purchase of the steamers referred to, five steampackets named Crgnet, Lapiwing, Duntrons Castle, Ptoneer and Dolpinn, so that in 1851 they controlled a fleet of about a dozen steamers. These 
steamers maintained a bi-weekly service (in addition to other sailings) between Glasgow and Inverness, sailing from Glasgow every Monday and Thursday, a service which has been maintained uninterruptedly for upwards of half a century. The Cygnet and Lapwing were built with their paddle boxes flush with their hulls, to enable them to pass through the Crinan Canal.

'Two new steamers, the Chevalier and Mouxtaneve, were added to the fleet in 1854. The following year (1855) the Clansman was built for the firm. The same year the Ioxa (the first of the name) was built, and maintained her reputation as a "crack" Clyde steamer until 186:3, when she was purchased by an agent of the Confederate States, to run the blockade during the American War. She, however, never crossed the Atlantic, being sunk, as the result of a collision, before she got clear of the upper firth.

She was promptly replaced by Iora (second of the name), launched the same year, which, after running for one season only, was also sold to run the blockade, but is supposed to have been lost with all hands off Lundy Island. The second Iora differed from her predecessors in having a saloon on deck.

Prior to her starting on her Atlantic voyage, this saloon was removed and placed on Ioxa the third. This steamer for many years bore the reputation of being the swiftest, as well as the most luxuriously appointed, steamer on the Firth of Clyde. The engines, which work with almost incredible smoothness, are of 1,625 horse-power, and are capable of propelling her at the rate of 18 knots per hour.

In connection with this vessel, the writer remember's a very amusing incident. Many years ago he was travelling by steamer from Liverpool to Glasgow, and in conversation a fellow-passenger stated that he had in the early part of the same summer sailed in the famous Iona from Glasgow to Ardrishaig.

"What do you think of the Kyles of Bute?" I asked.

"The Kyles of Bute," he replied ; "I never saw them."

The subject was dropped, until a little later he again spoke of his trip to Ardrishaig.

"And what do you think of the Kyles of Bute?" I again queried. 
"The Kyles of Bute; you asked me that before. I never saw them."

"But you say you sailed to Ardrishaig in the Iona?"

"Yes."

"Then you must have seen the Kyles-you could not possibly have gone to Ardrishaig without seeing them."

He seemed astonished, but after' a moment's thought a bright idea struck him, and he exclaimed-

“Ah! yes, I remember now, I saw a red board with gilt letters ' Kyles of Bute' on it; but I didn't go ashore-I never saw them."

Fortunately all men are not so unobservant; and so we find tourists from Great Britain and Ireland; from Canada and the United States; from South Africa and the Antipodes, journeying to enjoy not alone the beauties of the Kyles of Bute, but also the grand and beautiful scenery of the Western Highlands, now so easy of access by the splendid steamers of the MacBrayne fleet.

In 1862 was built the first of the trio of handsome screw steamers which sail regularly round the Mull of Cantyre to Stornoway and the far North. She is named the Clydesdale. A larger steamer, the Clansmax (second of the name), was built in 1870, and one still larger, the Claymore, in 1881.

Mr. David Hutcheson retired in 1876, leaving his partner, Mr. David MacBrayne, sole control of the business, which has since grown steadily, necessitating from time to time the addition of new steamers.

In 1878 the Royal Mail steamer Columba was built by Messrs. J. \& G. Thomson (now John Brown \& Co.), of Clydebank, who were also the builders of the Iova. She is the largest passenger steamer on the Firth of Clyde, and few, if any, cross-channel steamers exceed her in length. According to the official description of her, she is 316 feet in length, 50 feet in breadth (inclusive of paddle boxes), and 9 feet in depth. She is built entirely of steel, and is fitted with two oscillating engines of 220 nominal horse-power, but capable of working up to 3,000 indicated horse-power.

'Two years previously the R.M.S. CoLumba was refitted 
by Messrs. Hutson \& Sons, Limited, with two large tubulous boilers of the haystack type, made entirely of steel, and with twelve furnaces. When working at full pressure, she attains a speed of 22 miles per hour, and she is certified to carry over 2,000 passengers. The Colunis is steered by a steam steering engine, has the novelty of a set of steam bits at bow and stern by which the vessel is warped into piers, and has all the modern improvements introduced on board.

The upper saloon is very luxuriously fitted up, and in the interior are reading table, writing desk and lounges. The large square windows are carried round the sides and stern, affording a fine view of the scenery through which the steamer passes.

The breakfast and dining saloon, which is 8 feet high and well ventilated, has a series of separate circular tables, and meals are served at any time. The dining saloon (forward) for steerage or fore-cabin passengers is light and airy.

The ladies' and gentlemen's cabins are elegantly fitted up with the usual hand-basins and other conveniences.

There is a shampooing and hairdressing establishment, with a supply of every toilet requisite; a splendid bathroom, affording passengers who have travelled during the night the luxury of a salt-water bath, and a cloak room where they can leare hand-bags and other small articles. There are in addition a book stall and a fruit stall for cabin passengers, and for steerage passengers, a ladies' cabin forward and several stalls (fruit stalls, \&c.) are provided.

The only floating post office in the kingdom is to be found on board the Columba, and in it is transacted a larger amount of business than is transacted in many a provincial town. In it letters, telegrams and parcels are received, stamped, sorted and distributed at every calling place, for transmission to all parts, and it is of immense convenience to tourists and the inhabitants along the route. Upwards of 100,000 letters pass through this office in a month, of which a large proportion are local letters passing between the coast towns and villages at which the steamer calls. Over 450 telegrams were handed in, and upward of $£ 70$ received for postage and telegraph stamps 


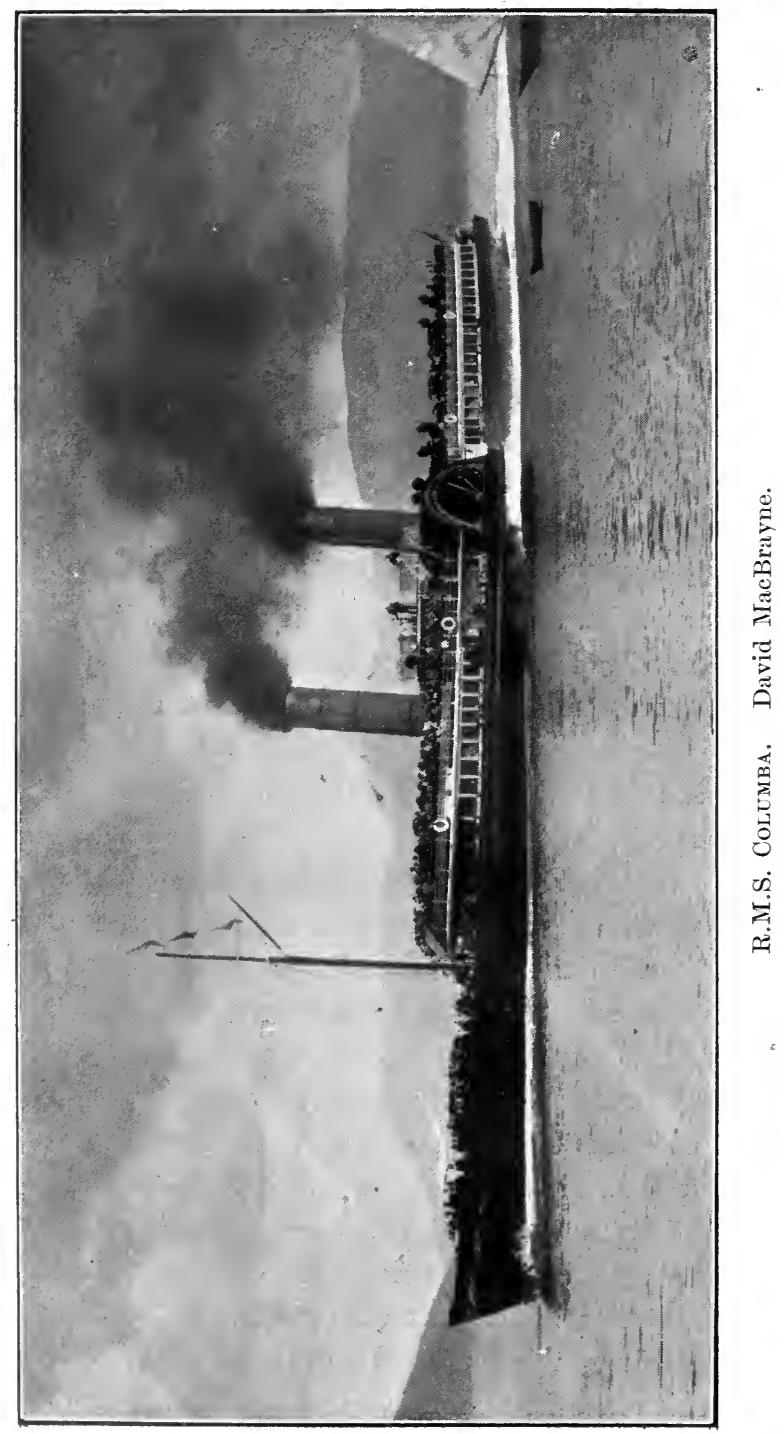


in one month. The most sanguine expectations of the Post Office Department being more than realised, has induced the Postmaster-General to add to the staff. Three post office officials travel with the Colombs. Postal orders can be purchased, and those issued at other offices in the kingdom cashed on board this steamer.

In $1902 \mathrm{Mr}$. David Macbrayne assumed as partners his two sons, Mr. David Hope, and Mr. Laurence MacBrayne, the name of the firm remaining unchanged.

Messr's. MacBrayne's steamers navigate every sound and loch between Port Ellen in the Island of Islay, off the South-west coast of Scotland, and Thurso in the extreme North, and visit almost every island between those two points.

The new steamer Lapwisg, built in the early part of the year 1903, proved very successful, and the firm have in course of construction another fine steamer, which is expected to be ready for the service early next year (1904). The fleet at present consists of thirty-one screw and paddle steamships, named as follows:-

\begin{tabular}{|c|c|c|c|c|c|c|c|c|c|}
\hline & & & $\begin{array}{l}\text { Horse } \\
\text { Power. }\end{array}$ & $\begin{array}{l}\text { Speed. } \\
\text { Knots. }\end{array}$ & & & & $\begin{array}{l}\text { Horse } \\
\text { Power. }\end{array}$ & $\begin{array}{l}\text { Speed. } \\
\text { Knots. }\end{array}$ \\
\hline Coluaba & ... & $\ldots$ & 3000 & 19 & Claymore & $\ldots$ & ... & 1450 & 15 \\
\hline Iona $\quad \ldots$ & ... & $\ldots$ & 1625 & 18 & Clansulan & $\ldots$ & $\ldots$ & 1250 & 14 \\
\hline Fusilier & ... & $\ldots$ & 900 & 15 & Clydesdale & $\ldots$ & $\ldots$ & 1000 & 13 \\
\hline Grenadier & $\ldots$ & $\ldots$ & 1050 & 16 & Cavalieir & $\cdots$ & ... & 1200 & 12 \\
\hline Chevalier & $\ldots$ & $\ldots$ & 1200 & 16 & FLOWERDALE & $\ldots$ & $\cdots$ & 1200 & 13 \\
\hline Gondolier & $\cdots$ & $\ldots$ & 600 & 12 & GLENDALE & $\ldots$ & $\ldots$ & 1400 & 15 \\
\hline Carabinier & $\ldots$ & $\ldots$ & 400 & 12 & STAFFA ... & $\cdots$ & $\cdots$ & 350 & 12 \\
\hline Mountaineer & R... & $\ldots$ & 500 & 15 & HaNdA ... & $\cdots$ & $\cdots$ & 250 & 11 \\
\hline GaEL $\ldots$ & $\ldots$ & $\ldots$ & 1500 & 16 & Етнац ... & $\cdots$ & $\cdots$ & 375 & 11 \\
\hline GLENGARRY & $\ldots$ & $\cdots$ & 350 & $\begin{array}{l}10 \\
12\end{array}$ & Fingal... & $\cdots$ & $\cdots$ & 325 & 11 \\
\hline GLencon: & $\ldots$ & $\ldots$ & 700 & & LOCHIEL & $\cdots$ & $\cdots$ & 410 & 12 \\
\hline Gairlochy & $\ldots$ & $\ldots$ & 500 & $\begin{array}{l}12 \\
12\end{array}$ & LINNFT... & $\cdots$ & $\cdots$ & 45 & 10 \\
\hline LOVEDALE & $\ldots$ & $\ldots$ & 1200 & $\begin{array}{l}12 \\
14\end{array}$ & MABEL ... & $\cdots$ & $\cdots$ & 35 & 10 \\
\hline LOCHAWE & $\ldots$ & $\ldots$ & 95 & $\begin{array}{l}14 \\
12\end{array}$ & TEXA & $\cdots$ & $\cdots$ & 250 & 10 \\
\hline LochNess & $\ldots$ & $\ldots$ & 420 & $\begin{array}{l}12 \\
12\end{array}$ & Countess & $\because$ & $\cdots$ & $\begin{array}{r}95 \\
500\end{array}$ & 8 \\
\hline & & & & & LAPWING & $\cdots$ & $\cdots$ & & 12 \\
\hline
\end{tabular}




\section{C'hapter XVI.}

\section{MESSRS. DAVID MAC IVER \& CO.}

The firm of Messrs. David MacIver \& Co. was originally founded by the late Mr. David MacIver and his brother Charles, in 1835. Mr. David MacIver had some four years prior to this date formed a steamship company to trade between Liverpool and Glasgow, which he called the City of Glasgow Steampacket Co. The pioneer steamer was named the CITY of GlasGow, and sailed on her first voyage from Liverpool on the 25th April, 1831. Three other steamers were quickly added to the fleet, viz., the Solway, Vulcan and Johr Wood, the latter steamer being named after a celebrated shipbuilder of Port Glasgow. In 1835 the CITY of GlasGow (second) was added to the fleet, and the same year Mr. Charles MacIver joined his brother, and the style of the firm was altered to Messrs. David MacIver \& Co., from that of the City of Glasgow Steampacket Co. On the 1st of June, 1837, the celebrated steamer Commodore was launched by Mr. John Wood, and made her first voyage, sailing from the Prince's Pierhead, Liverpool, on the 6th March, 1838. The Commodone was at that time considered to be the most powerful, most comfortable, and tastest sea-going steamer aftoat. The sister ship of this splendid steamer, the Admiral, was launched in the beginning of the year 1840, and proved a faster vessel than her consort. On her trial trip on the 2nd April, 1840, with a full deadweight cargo, she ran 16 miles in $56 \frac{1}{2}$ minutes, being five minutes less time than it was ever done by any other steamer.

In 1840 a Mail Steamship Service between Liverpool, Canada and the United States was established, the respective agents being Mr. Samuel Cunard, Halifax; Messrs. J. \& G. Burns, Glasgow; and Messrs. David and Charles MacIver, Liverpool, the latter being the practical managers of the 
company. This service, which afterwards acquired a worldwide reputation as the "Cunard Line," was modestly inaugurated by the despatch of the Liverpool and Glasgow steamer Uxicons (Captain Douglas), which sailed from Liverpool for Halifax and Boston on Saturday morning, 16th May, 1840. After she completed her outward voyage, she continued to ply between Pictou and Quebec, in connection with the British and North American Royal Mail Steamers.

In 1850 was instituted the steamship service between Liverpool and Havre, the pioneer steamer being the ComsoDORE, the well-known and favourite Liverpool and Glasgow steampacket. The coasting services were then carried on in the name of Charles MacIver \& Co. About the same date, steamship services to the Mediterranean were begun. The Havre and the Mediterranean business was conducted in the name of Burns and MacIver.

The elder of the two brothers (the founders of the "MacIver" steamship business), Mr. David MacIver, died unmarried in 1845. His brother, the late Mr. Charles MacIver, of Calderstones, then became the head of the firm, which position he held until his decease in 1885. In $1863 \mathrm{Mr}$. Charles MacIver admitted his eldest son, Mr. David MacIver, the present M.P. for the Kirkdale Division of Liverpool, into partnership. Mr. David MacIver remained a partner in the firms of D. \& C. MacIver, Charles MacIver \& Co. and Burns \& MacIver for eleven years, when he retired from all three firms, and established an entirely separate steamship business, resuscitating the old title of David MacIver \& Co. The first steamer built under the new regime was the Tuscary. She was built in $18 \pi 6$ by Messirs. J. \& G. Thomson, Glasgow, and engined by the same eminent firm. After running in Messrs. David MacIver \& Co.'s service for a number of year's, she was purchased by Portuguese owners, and she is believed to have again changed owners and to be now sailing under the Spanish flag as the Margarita.

The Sicily, the second steamer of the fleet, was built and engined by Messrs. Laird, Birkenhead, in 18r6, and was sold to the Cullum Steam Shipping Co., of London. 
The following year (1877) the Thessaly and Barbary were built for the firm by the builders of the Sicily. The latter steamer was sold, first to Messrs. Booth \& Co., who changed her name to the Clement, and subsequently to the Cia de Cabotagem do Grão Para, by whom she was named the Marajo, and placed under the Brazilian flag.

After an interval of five years, the Albany was contracted for, also with the Messrs. Laird, of Birkenhead. Mr. David MacIver's connection with Birkenhead is one of very long standing, and he has always laboured to promote its welfare and prosperity. In recognition of his services, he was the elected representative of the Borough from 1874 to 1885 . The Albany was considerably larger than any of her predecessors, her principal dimensions being-Length 300 feet 7 inches, breadth 39 feet 2 inches, and depth 26 feet 4 inches; with a deadweight capacity of about 3,500 tons. She was purchased by Messrs. T. W. Lunn \& Co., of Newcastle-on-Tyne, by whom she was re-named the WiLLowDENE.

A reference to the list of steamers built for Messrs. David MacIver \& Co. will show the distinguishing characteristic of the names to be the terminal letter $Y$. An amusing incident occurred in this connection during the building of the steamer Albany. A firm of north country shipowners, whose steamers were named after British dukes (omitting the prefix "Duke of"), had selected "Albaxy" for a vessel then under construetion, and they made the cool request to Messrs. David MacIver \& Co. to change the name of their steamer. It is needless to say they were unable to comply with this request.

For the first few years, the steamers named were not employed in any regular trade, though originally designed for the Mediterranean--hence the names Tuscany, Sicily, Barbary, Thessaly, \&c.-but traded, as inducement offered, to the Mediterranean, the Danube, the Black Sea, and elsewhere. They have formed part of the Anchor Line to Bombay, and of the Hall Line to the same port; and they have operated in the North Atlantic in the service of Messrs. Richardson, Spence and Co., between Liverpool and Philadelphia.

In 1883 Messrs. David MacIver \& Co. despatched their first 
steamer to the River Plate, and two years later they established a regular service between Liverpool and Buenos Ayres, Montevideo and Rosario.

In 1893, Mr. Charles Livingston, who had been associated with Mr. MacIver for two years previously, became a partner in the firm. Mr. Livingston takes a very active part in the management of the steamers, and he has devoted himself with great energy and success to the development of the River Plate trade with Great Britain. The five steamers named having become too small for the requirements of the service in which they were engaged, were disposed of, as stated, to various buyers and replaced by modern steamers of greater capacity and higher speed. These later steamers have all been designed specially for the River Plate trade, and although large carriers, are of remarkably light draught, thus enabling them to ascend to Rosario, without putting consignees and shippers to the risk and expense of transhipping cargo.

In 1894 contracts were placed with Sir Raylton Dixon \& Co., Middlesbrough, for three steamers of exactly similar dimensions and engine power. The first of these was the SAxoxy, launched December, 1894. She is a steel screw steamer of 3,500 tons deadweight, and fitted with triple-expansion engines (constructed by Blair \& Co., Ltd., Stockton) working up to about 1,500 horse-power effective. The following month (January, 1895) her sister ship, the Normandy, was delivered, and February of the same year witnessed the completion of the third vessel, the Lombardy.

The steamer which succeeded these was 1,000 tons larger. She is named the Brittany, and was built in 1898 by Messrs. Richardson, Duck \& Co., Stockton. She is a steel screw steamer, 330 feet long, by 43 feet beam and 16 feet 6 inches depth, with a deadweight carrying capacity of 4,500 tons. She is, like all her sister ships, propelled by tripleexpansion engines constructed by 13lair \& Co., Ltd., Stockton.

The opening of the 20th century was marked by a further and an important advance in the carrying capacity of the firm's steamers. Contracts were placed with Messrs. Richardson, Duck \& Co. for three steamers, two of which are each of about 
6,500 tons, and the third of about 5,500 tons deadweight. The first of the trio, the BARBARY (second of that name) was delivered in May, 1901, and the TARTary in July following. Both these vessels are practically identical as regards size and power. They are each 370 feet long, with a beam of 48 feet 1 inch, and a depth of 19 feet and a half. Their engines (tripleexpansion) develop 3,000 horse-power. In November of the same year the Burgundy, a vessel of somewhat smaller dimensions, was completed.

The fleet of Messrs. David MacIver \& Co.'s line to the River Plate at present consists of seven full-powered steamers, but before the close of the present year an eighth steamer, the Araby, now in course of construction, and of about the same dimensions as the Burgundy, will be placed on the service. Formerly the steamers were each registered as a single ship company, but in 1900 they were all incorporated in David MacIver, Sons and Co., Ltd.

The Directors of the Limited Company are David MacIver, Esq., M.P., his son Charles MacIver, Esq., and Charles Livingston, Esq. The steamers of Messrs. David MacIver and Co.'s line are deservedly popular with shippers and consignees in the River Plate trade, who are able to depend upon them for regularity of service and careful handling of their goods, and with underwriters for their freedom from serious accidents. All the steamers are comparatively new, and are fitted with the most modern and perfect appliances for the rapid and effective loading and discharging of general cargo.

Special attention has been given by the Company to the transit of cattle to and from the River Plate, and each of the steamers is fitted with permanent fittings for the conveyance of live stock. The headquarters of Messrs. David MacIver and Co.'s line are, and have always been situated in Liverpool, from which port it maintains a regular fortnightly service to and from Buenos Ayres, Montevideo and Rosario, throughout the year. 


\section{Cinapter XViI.}

\section{MACIVER'S LIVERPOOL AND GLASGOW STEAMERS.}

Is the autumn of 1826 the New Clyde Shipping Company advertised that their steampacket Exterpriss (Captain M'Farlane) would sail weekly between Liverpool and Glasgow. She was a very small steamer, being only 210 tons burthen, and the owners announced that, in consequence of her light draft, she would proceed direct to Glasgow, and not transfer her passengers to river steamers at Greenock, as the larger steamers had to do. The first agents of the company were Messrs. M'Nair and Brebner, 33, Water Street, but in January, 1829, the agency was transferred to Mr. David MacIver, 18, Water Street. A few months later the Glasgow and Liverpool Shipping Company was formed, and in 1831 that company acquired the Mersey and Clyde Steam Navigation Company's steampackets Hexry BeLi, James Watt, and Wy. Huskissox, as well as the Exterprise. The New Clyde Shipping Company having ceased operations, Mr. MacIver formed a new steamship line of his own, which he called the City of Glasgow Steampacket Company. The pioneer steamer was named the CITY of GLasGow and sailed on her first voyage from Liverpool on the 25th April, 1831. Three other steamers were quickly added to the fleet, viz., the Solway, Vulcax, and Join Woon, the latter steamer being named after a celebrated shipbuilder at Port Glasgow. In 1835 the Citr of Glasgow (second) was put on the station, and the sailings were increased to three per week from each port. Mr. Charles MacIver joined his brother this year, and the style of the firm was changed to D. MacIver \& Co. 
In 1837 the celebrated steamship Commodore was built, followed in 1840 by her equally famous sister ship, Admiral.

All the steamers engaged in the Liverpool and Glasgow trade prior to 1839 were built of wood, but in that year a new steamship company entered into competition with the existing companies, and placed the Royal Sovereign, an iron steamer, on the station., The immediate result was a heavy drop in passenger and freight rates. Steerage passengers were carried for $1 \mathrm{~s}$. each, and boxes and bale goods for 1d. per foot measurement. The following year (1840) a mail steamship service between Liverpool, Canada, and U.S.A. was established, the respective agents of the company being D. and C. MacIver, Liverpool; J. and G. Burns, Glasgow ; and Samuel Cunard, Halifax. This service, which afterwards acquired a world-wide reputation as the "Cunard line," was modestly inaugurated by the despatch of the Liverpool and Glasgow steampacket Unicorn (Captain Douglas). This vessel (the real pioneer of the Cunard line) sailed from Liverpool for Halifax and Boston on Saturday morning, 16th May, 1840. After she completed her outward voyage, she continued to ply between Pictou and Quebec in connection between the British and N.A. Royal mail steamers. Although there were three perfectly distinct steamship companies trading between Liverpool and Glasgow, yet so friendly were the respective owners towards each other that in 1846 they issued a joint sailing bill, which included the whole of the sailings for all the companies. This arrangement continued unchanged for seven years (1853), at the end of which period the Princess Royal was advertised separately. At this date the quickest, cheapest (although the fares were louble what they now are), and most comfortable mode of travelling between Liverpool and Glasgow was by steamer. The steamers were large, swift, and luxuriously furnished, and so numerous were the passengers that the joint companies maintained a daily service. From the year 1853 the two services, the MacIver and the Burns, were amalgamated, the joint line being represented in Liverpool by Chas. MacIver \& Co., and in Glasgow by G. and .J. Burns. In 1850 Messis. Chas. 
MacIver \& Co. instituted the steamship service between Liverpool and Havre, the pioneer steamer being the Commodore, the well-known Liverpool and Glasgow steampacket. About the same date the steamship services to the Mediterranean were begun by Messrs. MacIver, under the style of Messrs. Burns and MacIver. Until the year 1853 no distinctive class of name had been adopted for the coasting steamers of the MacIver line, but in that year the ELK and STAG were built, followed by the Lyxx and Sтоrк. These were the last of the paddle-steamers built to run between Liverpool and Glasgow. In 1855 the owners decided to place screwsteamers on this station, and accordingly built the screwsteamers Otter, Beaver, and Zebra. The ZeBra was a large and powerful vessel, and was amongst the earliest of the steamers taken up by Government for transport duty during the Crimean war. All the succeeding steamers have been of the same type, and have been named after animals or birds. The joint service remained in force for nearly half a century, until (in 1895) Messrs. G. and J. Burns opened an office in Liverpool, and placed the steamers Mastiff, Pointer and Spaniel on the station. The elder of the two brothers (the founders of the "MacIver" steamship business), Mr. David MacIver, died unmarried in 1845. His brother, the late Mr. Charles MacIver, of Calderstone, then became the head of the firm, which position he held until his death in 1885 . The long connection of the "MacIvers" with the Cunard Company was terminated in 1883, and they retired from the management. Messrs. Charles and Henry MacIver (the younger sons of the late Mr. Charles MacIver) retain the old styles of D. and C. MacIver (for their foreign trades) and Chas. MacIver \& Co. for the steamers trading between Liverpool and Glasgow.

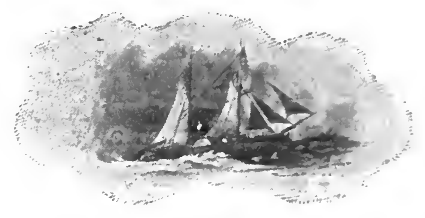




\section{Chapter XViII.}

\section{SLIGO STEAM NAVIGATION CO., LTD.}

During the first half of the last century Messrs. Middleton and Pollexfen, of Sligo, owned a large fleet of sailing vessels. Some of these vessels were barques which traded to foreign ports, but others were swift, staunch schooners which traded regularly between Sligo and Liverpool, and Sligo and Bristol (hannel and Glasgow. But the schooners laboured under one serious disadvantage - the uncertainty of the duration of the passage. With favourable weather it might be accomplished in a few days, but with adverse gales or fogs it might occupy as many weeks. It is self-evident that, in competition with steamers, schooners have no chance of success, so in 1856 Messrs. Middleton and Pollexfen decided to employ steam in their Sligo and Liverpool trade, and for this purpose built a small steamer, which they named the Stico. The following year (185\%) they put the Sitgo on the Sligo and Glasgow station in opposition to Messrs. Cameron and Co. Five years later (1862) a company was formed with the title of the Sligo Steam Navigation Company, Limited, which took over the steamship business of Messrs. Middleton and Pollexfen, and which has continued to flourish, financially and otherwise. The company in 1865 built a larger steamer than the St.JGo, and nameil her Liverpoot. The opposition in the Sligo services began under the regime of Messrs. Middleton and Pollexfen, continued for some years after the formation of the Sligo Steam Navigation Company, but was finally settled amicably. Messrs. Alexander A. Laird and Co. (successors to 
Messrs. Cameron and Co.) retired from the sligo and Liverpool trade, and the sligo Company withdrew from the Gilasgow trade, purchasing the Gardaxn, which they rellamed the Grasgow. IIaving disposed of the Sutgo, the company purchased a swift Clyde-built cargo and passenger steamer', to which they transferred the name. The Livirpoor was sold in 1892 to Preston buyers, but has been for several years, and is now, employed by the Cunard Company to maintain their Liverpool and Havre service. The same year the largest steamer yet built by the company was placed on the Liverpool and sligo station. The new vessel (the Liverpool.) was constructed by Messrs. John Jones and Sons, of Liverpool, and was built to the specifications and under the supervision of Mr. II. II. West, the naval architect for the sligo steam Navigation Company. She is a smart-looking boat of the following dimensions:--Length between perpendieulars, 206 feet; breadth, moulded, 29 feet; and depth, 15 feet $3 \frac{1}{2}$ inches. Her gross register is $\tau 00$ tons, and net 332 tons. The carriage of cattle being a very important feature of the trade, careful consideration has been given to the cattle fittings. Being a larger vessel than any of her predecessors, increased accommodation is also provided for saloon and deck passengers, as the trade is increasing in this direction very considerably. The saloon and cabins are fitted up in a substantial and comfortable manner. The engines (triple expansion), also constructed by Messis. Jones and sons, are of 1,000 indicated h.p. On her trial trip the Liverpool. attained a speed of 13 knots, being a knot in excess of contract speed. The ship is lighted throughout by electricity. The loading berth for the eompany's steamers was, originally, in the Trafalgar Dock, but is now on the east side of the Clarence Basin, a berth they have oceupied since about 186ii. The company despatches the Liverpoor or Sidgo once a week between the two ports, sailing from Liverpool every Thusday, and from Sligo every Saturday. In addition to this, its main service, the company has a Government contract, on which the steamer TARTAR is employed. This steamer sails twiee a week in winter, and three times per week in summer, from 
Sligo to Belmullet, calling at Rosses Point, Ballycastle, and Belderrig, to land and embark passengers. It is a favourite tourist route in summer, affording a splendid view of the wild coast scenery of the West of Ireland. The distance run is about 70 miles, and the time occupied about six hours. The steamers of the Sligo Steam Navigation Company, sailing between Liverpool and Sligo, are exposed to all the force and fury of the Atlantic gales, as they steam along the north and north-west coasts of Ireland. It is, therefore, an eloquent testimonial to the strength of their construction, as well as to the ability with which they are managed, and navigated, that they sail with unfailing regularity in winter as in summer, and with a most gratifying freedom from accidents.

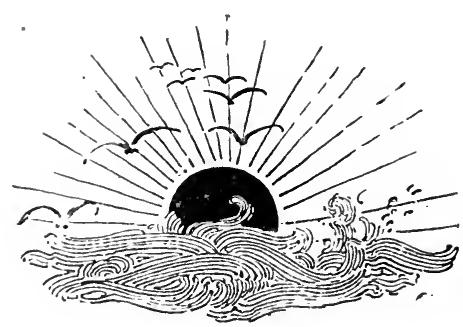




\section{Chapter XiX.}

\section{WATERFORD STEAMSHIP COMPANY.}

EarLY in the year 1836 several Waterford merchants determined to run steamers between Waterford and Liverpool in opposition to the steamers owned by the Messis. Pope, of the former port. Accordingly, on the 11th Jannary, 18:3\%, there was launched from Mr. John Laird's yard, Birkenhead, the Duncannon, a small iron paddle-steamer of 200 tons burthen, to the order of the Waterford Commercial Steam Navigation Company, represented in Liverpool by Archer, Daly \& Co., of 2, Cook Street. Three years later (1840) a second steamer, the Wm. Pens, was added to the service. The new company was so successful in its venture that in a short time the Messrs. Pope either abandoned the trade, or were absorbed by their rivals, who thereupon appear to have adopted the title of the Waterford Steamship Company. There had been for years keen rivalry between the St. George Steampacket Company and the City of Dublin Steampacket Company, and when the business of the former was transferred to the Cork Steamship Company, the directors of the City of Dublin Company were by no means favourably disposed to the new management. This unfriendly feeling was extended to the Waterford Steamship Company, because Mr. Joseph Malcomson (chairman of the latter company) was offered, and accepted, a seat on the board of the Cork Steamship Company, and his firm (Messrs. Malcomson Brothers) invested largely in the Cork Company's shares. The following year the Waterford and Kilkenny Railway was opened from Waterford to Thomastown. The directors asked the Waterford Steamship Company to change their loading berth from the south side of the River Suir to the north side, adjacent to the railway company's terminus. This the steamship company refused to do. In consequence of this refusal, the Waterford and Kilkenny Railway Company induced the City of Dublin Company to put on steamers between Waterford and Liverpool. But, as the City of Dublin Company had no 


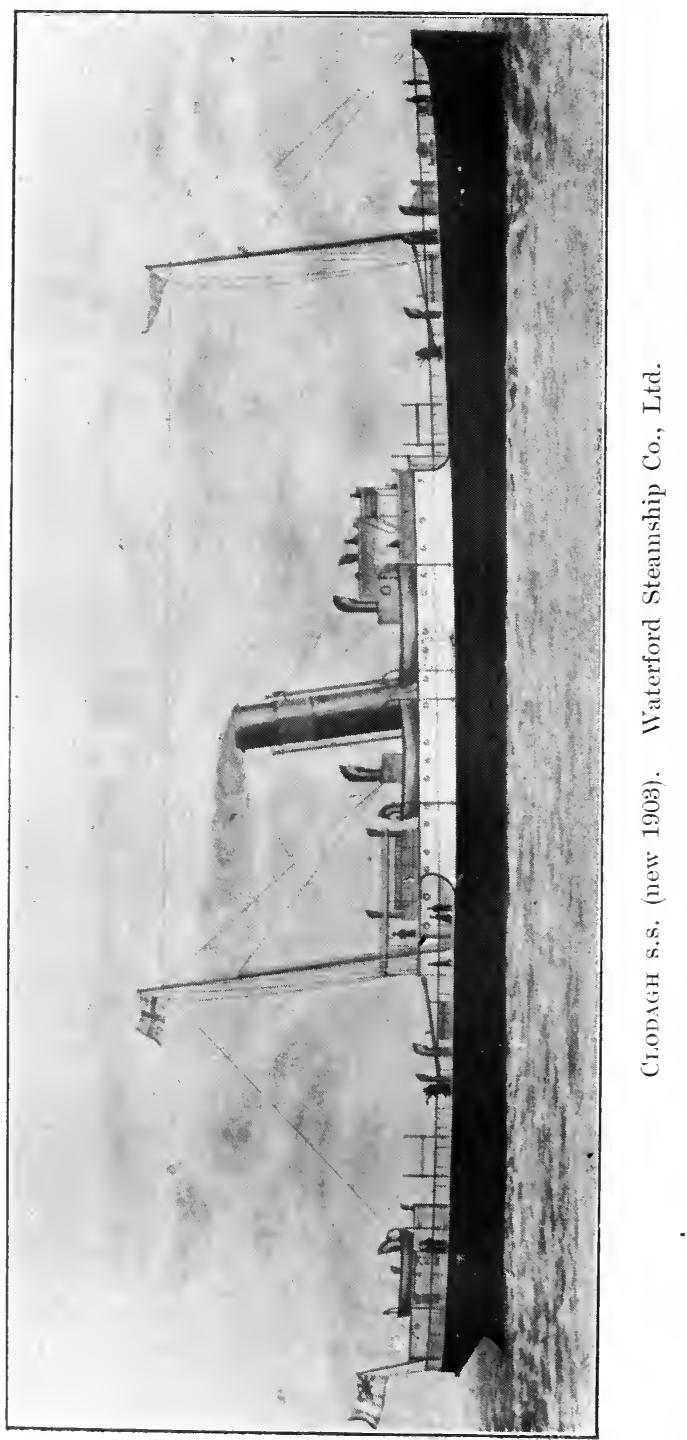


steamers of their own available, they chartered steamers from the British and Irish steampackst Company, which they placed on the Liverpool and Waterford station. Meantime. the Waterford Steamship ('ompany harl not been idle. The late Liverpool agent of the company (Mr. George K. Payne) was detailed to organise an opposition to the railway company, with emphatic instructions not to permit a single passenger to be carried by the railway company betwen Waterford and Thomastown, or vice iersa. The distance was only twelve miles, and an efficient car service was at once established between the two towns. Not only was the service an efficient one, but, rather than permit passenger's to travel by the railway company, the drivers of the cars would take them for nothing. Of course, there were not wanting those who prophesied that the Waterford Company and the Messis. Malcomson (who had acquired the whole of the steamship) company's shares) would be ruined by the opposition. Malcomson Brothers, however, referred inquirers as to their stability to Messr's. Overend, Gurney \& C'o., then at the zenith of their power, whose reply was:-"We guarantee Messrs. Malcomson Brothers to the extent of two milliom pounds sterling."

Equally fierce was the opposition in the cross-channel service. Passengers were frequently carried without charge between Liverpool and Waterford, as well as between Liverpool and Dublin. A story is told of a passenger going into the Dublin Company's office in Waterford, and asking what the cabin fare was to Liverpool. He was told he would be taken for sothing, to which he replied, "'That is not good enough; you must feed me as well." A similar tradition exists with regard to the Liverpool and Dublin service, namely, that when one of the rival companies advertised its willingness to carry passengers for nothing, and to give them a loaf of bread, the other company capped the offer by the addition of a bottle of Guinness' stout. Not content with carrying the war into the enemy's country by running horsecars between Waterford and Thomastown, the Waterford Steamship Company placed their steamer Liox on the Liver- 
pool and Dublin station, and chartered a steamer from the Cork Steamship Company to run in opposition to the British and Irish Company between Dublin and London. Thereupon, the British and Irish Company chartered a steamer from Langtry's Belfast Steamship Company to run between Liverpool and Cork, and the Cork Company, as a counter move, placed their steamer Minerva on the Liverpool and Belfast station. The opposition was maintained with unabated fierceness for about three years, at the end of which time the City of Dublin Company and the Waterford Company arrived at an amicable settlement, each company agreeing to cease opposing the other. The Belfast Steamship Company and the British and Irish Company having now to bear the brunt of the opposition, without the support of the City of Dublin Company, deemed it wise to make the best terms they could with their opponents. Accordingly, the Belfast Company divided the Liverpool and Belfast trade with the Cork Company, and the British and Irish Steampacket Company shared their London and Dublin trade with the Waterford Steamship Company. The Cork Company continued to run steamers between Liverpool and Belfast for several years, but were eventually bought off by the Belfast Steamship Company. The Waterford Company ran two steamers regularly between London and Dublin until the year 18r0, when they also were bought off by the British and Irish Steampacket Company. Prior to the City of Dublin Company's opposition, the Bristol Steam Navigation Company and the Waterford Steamship Company had maintained a joint service between Waterford and Bristol. The Bristol Company's boat left Waterford on Tuesday to catch the Bristol cattle market, and the Waterford Company's boat left Waterford on Friday. As a consequence of the low rates which were in force during the opposition, a great deal of traffic was diverted from the Bristol route to the Liverpool route, and the Bristol Company suspended their sailings to and from Waterford. The Waterford Company thereupon took up the Tuesday sailings to Bristol. When the Liverpool opposition ceased, the Bristol Company wished to resume 
their Tuesday sailings from Waterford. The Waterford Company, however, refused to withdraw their 'Tuesday steamer, but agreed to let the Bristol Company have the Friday sailing. The close and friendly relationship which had formerly existed between these two companies became somewhat strained, and ultimately ended in so wide a breach that the Waterford Company purchased the paddle steamer Victory from the Cork Steamship Company, and placed her on the station between Bristol and Dublin, in opposition to the Bristol Steam Navigation Company. This opposition was withdrawn upon the Bristol Company undertaking to pay the Waterford Company an annual sum of $£ 1,000$, which sum they continued to pay for a great many years. About the year 1847, Malcomson Brothers (the owners of the Waterford Steamship Company) purchased the steamer Dubis, for employment in one of their London trades. She was the first screw steamer owned by any Irish company or firm, and she proved so successful that her new owners had all their subsequent steamers fitted with screws, except one boat for a special trade. Being shareholders in the Peninsular and Oriental Steam Navigation Company, Malcomson Brothers induced the directors of that company to introduce screw steamers into their fleet. It was also by the advice of Messrs. Malcomson that Richardson Brothers, the promoters and first managers of the Inman line, built screw steamers for the Atlantic. The Messrs. Malcomson were no mere theorists in steamship construction; they decided to build the steamers they owned. For this reason they established (in 184i) an iron shipbuilding and engineering works at Waterford, under the style of the Neptune Iron Works. They were fortunate in securing for their manager a talented shipbuilder, the late Mr. John Horn, who was succeeded by his son, Mr. Andrew Horn, an engineer of very exceptional abilities, and who is the present superintendent engineer of the company. About 40 steamers were built at the Neptune Iron Works before they were closed, several of which became famous, and all of which were noted for their strength of hull and engines.

In 1849 the Waterford Steamship Company (Malcomson 
Brothers) built at their Neptume Iron Works, Waterford, the steamer Mans. Her original plans, which were for a paddleboat, were altered while she was on the stocks, and she was launched a serew steamer. She was the first screw steamer placed on the Liverpool and Waterford station, and at first the cattle shippers did not like the idlea of shipping by her, especially as on one of her early voyages she heeled orer on leaving Waterford (2uay, and killed a large number of eattle; but the late Captain Burns was put in command, and she proved herself to be a safe carrier, and speedily became a favourite boat in the trade. Two years prior to this date (184i) Malcomson Brother's built at the same yard the steamer Neproxe- this was the first steamer built at the Neptune Iron Works, and she was also the first steamer to run to st. Petersburg. It happened in this way. The Russian Govermment were very anxious to get a line of steamers established between lingland and St. Petersburg, and made overtures on the subjeet to Malcomson Brothers. As a result, the latter agreed to start a line from London, of which the pioneer steamer was wrecked in the Baltic on her first outward voyage. The Nerroxe was then despatched. When she arrived at Cronstadt the Mayor of St. Petersburg came on board in state, and as she steamed up the Neva, II.I.II. the Crar Nicholas met her in his state barge; the forts and warships fired salutes of honour, and all the merchant ships were covered with flags. To commemorate this important event, his Majesty the (Yar commanded that whenever the Neptune eame to st. Petersburg she was to be free of port and pilotage dues.

At the time of which I write, it was impossible to overestimate the influence of Maleomson Brothers in the eommercial steamship world. We have seen how they were consulted by the directors of the $P$. and $O$, and by the promoters of the Inman line. In addition to their coasting Heets they had steamers in the Eastern trade, one of whichthe UNA - was one of the first steamers to pass through the Suez Canal. They were also the pioneers of the Liverpool and River Plate trade, and were, I believe, the predecessors 
of Lamport and ILolt. Amongst the large fleet of steamer's built for the Waterford Steamship Company at their own shipbuilding and engineering works was a serew stemer, the Wirlian Pexs. This steamer was sold by the Waterford Steamship Company, and her new owners, having lengthened her and given her a fourth mast, renamed her the livoprsx. As the European she ran for a number of years in II. $X$. Hughes and Nephew's line between Liverpool and 13ombay. She afterwards was transferred to, or chartered by, Geo. Warren and Co., and while in their Boston and Liverpool service, in the early seventies, she had the proul distinc:tion of being the first steamer to bring to Lirerpool an importation of American live cattle, consigned to Giro. Roddick and Co., Chapel, Walks. Since the withdrawal of the Malcomsons from the active control of the company, the management of the Waterford Steamship ('ompany has been rested in Mr. C. Morley, under whose able management the steamers have been maintained in a state of thorough efficiency and up-to-dateness. The fleet of the company at the present date consists of the following powerful steamer's, which make their passages to and from Liverpool and IVaterford with unfailing regularity in about 18 hours, summer and

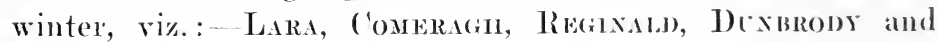
Mexalia.

The Dunbrons has a complete installation of electric light, including the holds, and her lower holds for the entire length form a refrigerator. A further and larger addition, the Clobsan, now building, will shortly be added to the fleet, embracing all the above improvements, with an increased speed, and increased first-class passenger accommodation.

The Waterford Steamship Company were anongst the first steamship owners to discard the bowsprit and figure-head, and to adopt the straight stem. They were also amongst the first owners to build steamers with saloons amidships, and it is their proud boast that in the Liverpool and Waterford service, extending over sixty years, they never lost a ship or a human life. 


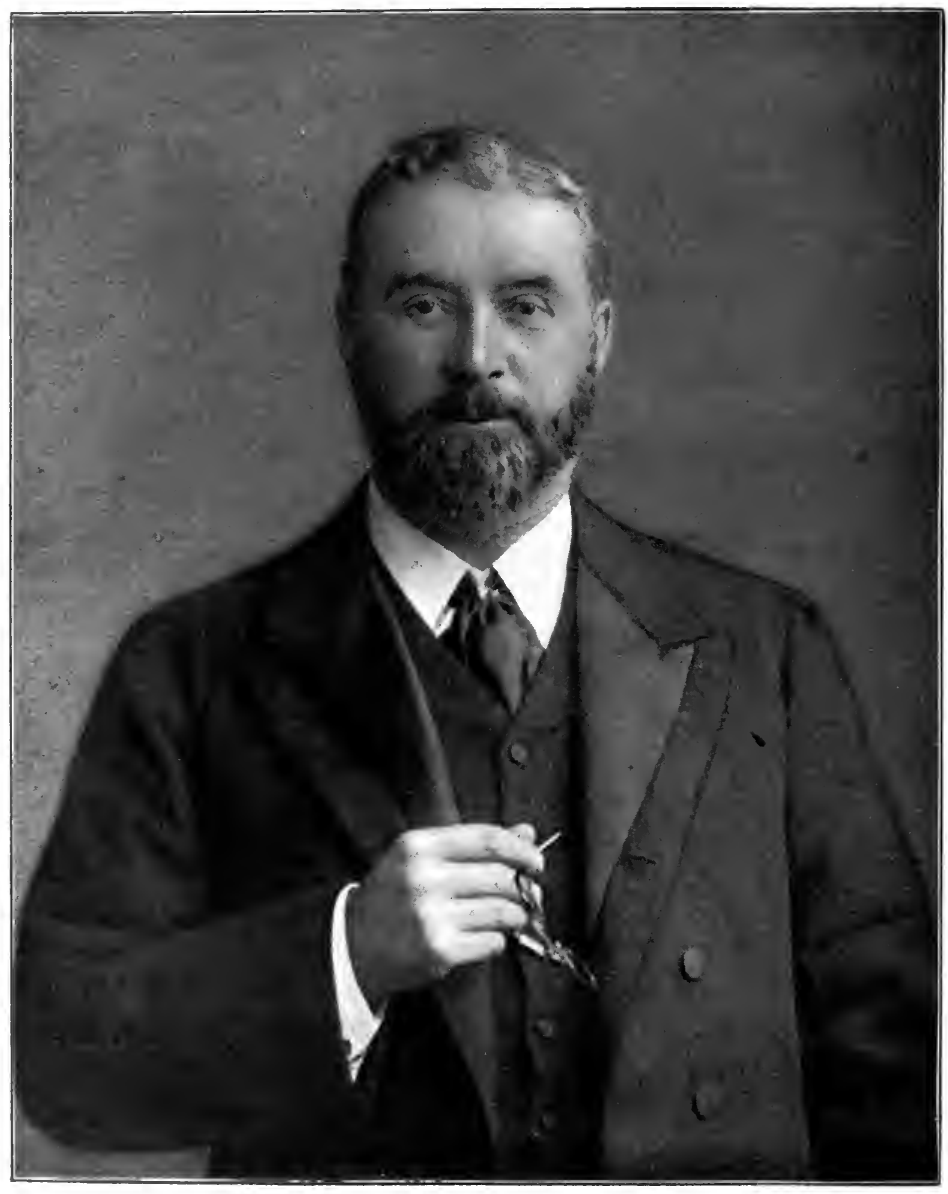

The late T. H. Ismay, Esq. 


\section{Chapter XX.}

\section{WHITE STAR LINE.}

THE White Star Line was founded about the middle of the last century by the owners of a line of smart clippers sailing between England and Australia. The great rush of adventurers to the Australian gold diggings in the "fifties" gave a great impetus to the trade between Great Britain and the Colonies. In the course of seven years the White Star, Black Ball and other lines carried about half a million passengers to the Antipodes. The "White Star" boats, even in those days, were the largest of their class, and amongst them were the famous wooden clippers Golden Era, Champion of the Seas, Blue Jacket, and White Star, vessels of from 3,000 to 4,500 tons gross. An important change took place in the destinies of the line in 1867, when the managing owner retired, and the late Thomas Henry Ismay took over the flag. Two years later came the great event in the history of the White Star Line, when Mr. Ismay induced some friends to join him in the formation of the Oceanic Steam Navigation Company. It was an enterprise boldly conceived, and carried out with great judgment. Boldly conceived, for there were already four companies each maintaining a regular weekly service between Liverpool and New York. Nor were these small companies, or of indifferent reputation. There was the Cunard Company, established about thirty years previously; the Inman Line, with a fine fleet of clipper passenger steamers; the Guion Line, with its large American connections; and the National Line, with its fleet of huge cargo carriers. In spite of this, Mr. Ismay was confident that there was room for a high-class Trans-Atlantic passenger service, and the shares in the new company (£1,000 each fully paid) were at once privately taken up by the firm of T. H. Ismay \& Co. and their friends, 
amongst whom were some of the most substantial names in Bugland. The following year Mr. Imrie (of the late firm of Imie, Tomlinson \& Co.) joined Mr. Ismay, and the style of the firm was altered to Ismay, Imrie \& Co.

The first step taken by the managers of the Oceanic Steam Navigation Company was to arrange with the celebrated shipbuilders, Messr's. Harland and Wolff, Belfast, for the construction of a fleet of high-class steamships, expressly for the American passenger trade. The pioneer vessel of the line (the OcFanic) was launched on the 2rth August, 18\%0, and started on her maiden voyage under the White Star flag on the 2nd March, 1871. After rumning for several years between Liverpool and New York, this steamer (Ockasic, the first), along with her sister ships, GAELIC and BELGic, were chartered to the Occidental and Oriental Steamship Company, of San Francisco, to maintain a mail service between that port and the Orient. The Ockasic was quickly followed on the Liverpool-New York service by the Battic, Repubic, Aimiatic and Ceristc, and weekly sailings from both ports were instituted. These steamers were all of the one type, straight stems, four masts, single funnel, and saloon amidships. They proved themselves to be equal in speed and superior in accommodation to any ships then afloat. Four mole steamers were added to the fleet in 1873, viz., the Astatic, Tropic, Gaflic and Bergic. A great advance on the earlier steamships was made in 1874, when the BRITANxIC was launched, followed by her sister ship, the Gremaxic, in 1875. Prior to the formation of the White Star Atlantic Fleet, the

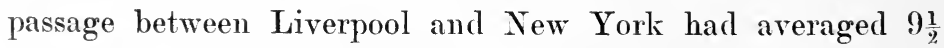
or 10 days, the OcFanic and her consorts reduced it to about $8 \frac{1}{2}$ days, whilst the Britannic and Gromanic brought the time down to about $7 \frac{1}{2}$ days.

'These vessels, with the exception of the two last named which were larger and faster, were almost uniform in size and speed. These, and the later vessels of the fleet, were designed and built to attain the three-fold purpose of safety, speed and comfort, and their performances have certainly realised the expectations of their owners. Speed has been an important, 
but a secondary, consideration, as is shewn by the following extract from the "Book of Regulations" of the White Sitar Line of steamers :-

"The commanders must distinctly understand that the " issue of the following instructions does not, in any way, " relieve them from entire responsibility for the safe and "efficient navigation of their respective ressels; and they" "are also enjoined to remember that, whilst they are "expected to use every diligence to secure a speody. "voyage, they must rum no risk which might by auy" "possibility result in accident to their ships. It is to be "hoperl that they will ever bear in mind that the safety of "the lives and property entrusted to their care is the " ruling principle that should govern them in the naviga"tion of their ships, and no supposed gain in expedition "or saving of time on the voyage is to be purchased at the "risk of accident. 'The company desires to establish and " maintain for its vessels a reputation for safety, and only "looks for such speed on the various voyages as is con" sistent with safe and prudent navigation."

Not content with giving this general regulation, the managers have issued to the commanders of the respective ships of the fleet a special autograph letter, laying special emphasis on the supreme importance of extreme and unvarying caution and prudence in the navigation of the company's vessels. 'The concluding paragraph of this letter is as follows :--

" Ender all these circumstances of paramount and " engressing interest to the company, whose property is " under your charge, we invite you to dismiss from your " mind all idea of competitive passages with other vessels, "the advantage of success in which is merely transient, " concentrating your whole attention upon a cautious, "prudent, and ever-watchful system of navigation

" which shall lose time, or suffer any other temporary" "inconvenience, rather than run the slightest risk which "can be avoided."

The BRITAxic when she first came out was fitted with a 
novelty in the shape of a "lifting propeller." This propeller was a patent of the late Sir Edward Harland, senior partner of the firm by whom the Britarnic was built. In long ships the pitching in a heavy sea, and the vertical motion of the waves, tend to expose the upper portion of the propeller, the evil effects arising from this being the "racing" of the engines and its attendant dangers, together with a diminished speed. Sir Edward Harland believed that a propeller which could be worked at any depth, and which did not require the stoppage of the vessel whilst it was being raised or lowered, would reduce these risks to a minimum, if it did not entirely remove them. In actual practice, however, it was found that the advantages of the new principle did not compensate for its disadvantages, and, after a fair trial had been given to it, it was abandoned in favour of the old style of screw. In a letter, dated 3rd December, 1874, addressed to the late Mr. W. S. Lindsay, Messrs. Ismay, Imrie \& Co. state :- “ The average speed of the "Britannic is fifteen knots per hour on a consumption of 75 " to 80 tons of coal per day, and her approximate cost, built "without contract, is $£ 200,000$."

From 1873 until 1884 the White Star Line maintained its position as the fastest fleet on the Atlantic, a result to which the Britannic and Germanic contributed in no small degree. In September, 1890, the Britannic eclipsed her own previous record of 7 days $9 \frac{1}{2}$ hours, by crossing from New York to Queenstown in 7 . days 6 hours 55 minutes, at an average speed of 16.80 knots. The following year (September, 1891) she surpassed even this rapid passage, by making the run from New York to Queenstown in 7 days 6 hours 52 minutes. While employed by H.M.S. Government to convey troops during the late war in South Africa, she made the run from Queenstown to the Cape in 19 days, a speed surpassed by few of the transports engaged. In August, 1891, the Germanic following in the track of her sister ship, travelled from New York to Queenstown in 7 days 7 hours 37 minutes, at an average speed of 16.10 knots per hour. When it is remembered that this high speed (nearly nineteen statute miles per hour) was attained by vessels over 20 years old, with 
their original compound engines and boilers, it will be acknowledged that, having regard to their small coal consumption and large carrying capacity, the Britanxic and Germanic have given results unattainable with the fastest ships of the present day.

The Germanic in 1895 received new engines and boilers, and had her passenger quarters entirely remodelled on the plan of the Majestic and Teutonic. In July of that year she crossed from Queenstown to New York in 6 days 23 hours 45 minutes, and in August of the year following in 6 days 21 hours and 38 minutes, thus showing a substantial increase of speed.

After the launch of these two famous steamers, there was an interval of six years during which no new vessels were added

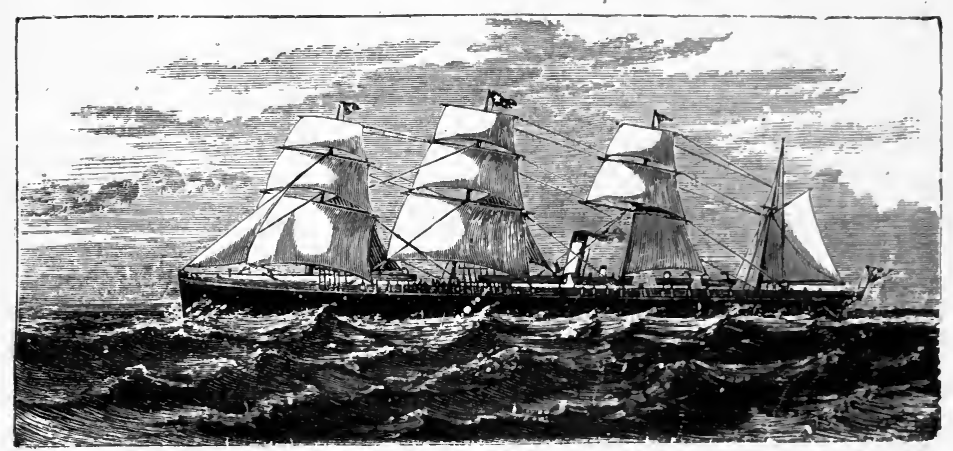

OCEANIC (1870). White Star Line.

to the fleet. The next additions were the ArabIC and Coptic, for the Trans-Pacific trade, in 1881. In the same year Mr. W. S. Grares, son of a well-known former M.P. for Liverpool, became a partner.

In 1883 the IonIC and DonIc were built for the New Zealand trade-the Shaw, Savill and Albion Line from London. In 1885 the GaELIC and Belgic-replacing the two older ships of the same names-were built for the TransPacific trade. A new type of steamer for the cargo and cattle trade between Liverpool and New York was introduced in 1888, the two first steamers of the new type being the Curic and Runic. These vessels were the last single screw ships 
ordered for the White Star Line, all the succeeding vessels being of the twin-screw type. The Curic and RunIc proved successful enough to warrant the company in forming a complete service of cargo and cattle steamers. After doing very efficient service as cattle carriers, the Curic was sold to a Liverpool firm, who changed her name to the Manxman, and the Runic, also sold to a Liverpool firm, is engaged in the West Indian trade under the name of the Tampican.

In January, 1889, was launched the Teutonic, the first of the celebrated pair of twin-screw mercantile armed cruisers (Teutonic and Majestic), each 10,000 tons, which have since made for themselves a great reputation in the New York mail and passenger service. The keel of the Teutonic was laid in March, 1887. The vessel was launched 22 months later, and she left Liverpool on her maiden voyage to New York on the 7th August, 1889. Prior to going on to her regular station, she was present, armed with eight quick-firing guns, at the naval inspection by the German Emperor at Spithead in the beginning of August, 1889. On that occasion she astonished nautical critics with her splendid proportions, and was honoured by a special visit from H.I.M. the Kaiser, and H.R.H. the Prince of Wales (now H.M. King Edward VII.). She was again present with a large party of guests at the Diamond Jubilee Naval Review in June, 1897, when she carried an armament of 16 guns. Her sister ship, the MaJestic, was launched on the 29th June, 1889, but did not start on her first voyage until the 2nd April, 1890.

The length of time occupied in the building of these great ships is sufficient evidence, if any were needed, of the great care bestowed on their construction, and the builders, Messrs. Harland \& Wolff, have their reward in witnessing the successful work which is being performed by two of the finest vessels the world has ever seen. These two beautiful vessels quickly lowered the record on the Atlantic. In July, 1891, the Majestic steamed from Queenstown to New York in 5 days 18 hours and 8 minutes, the fastest passage then on record, but even this was eclipsed by the Teuronic the succeeding month by a passage of 5 days $16 \frac{1}{2}$ hours duration. 


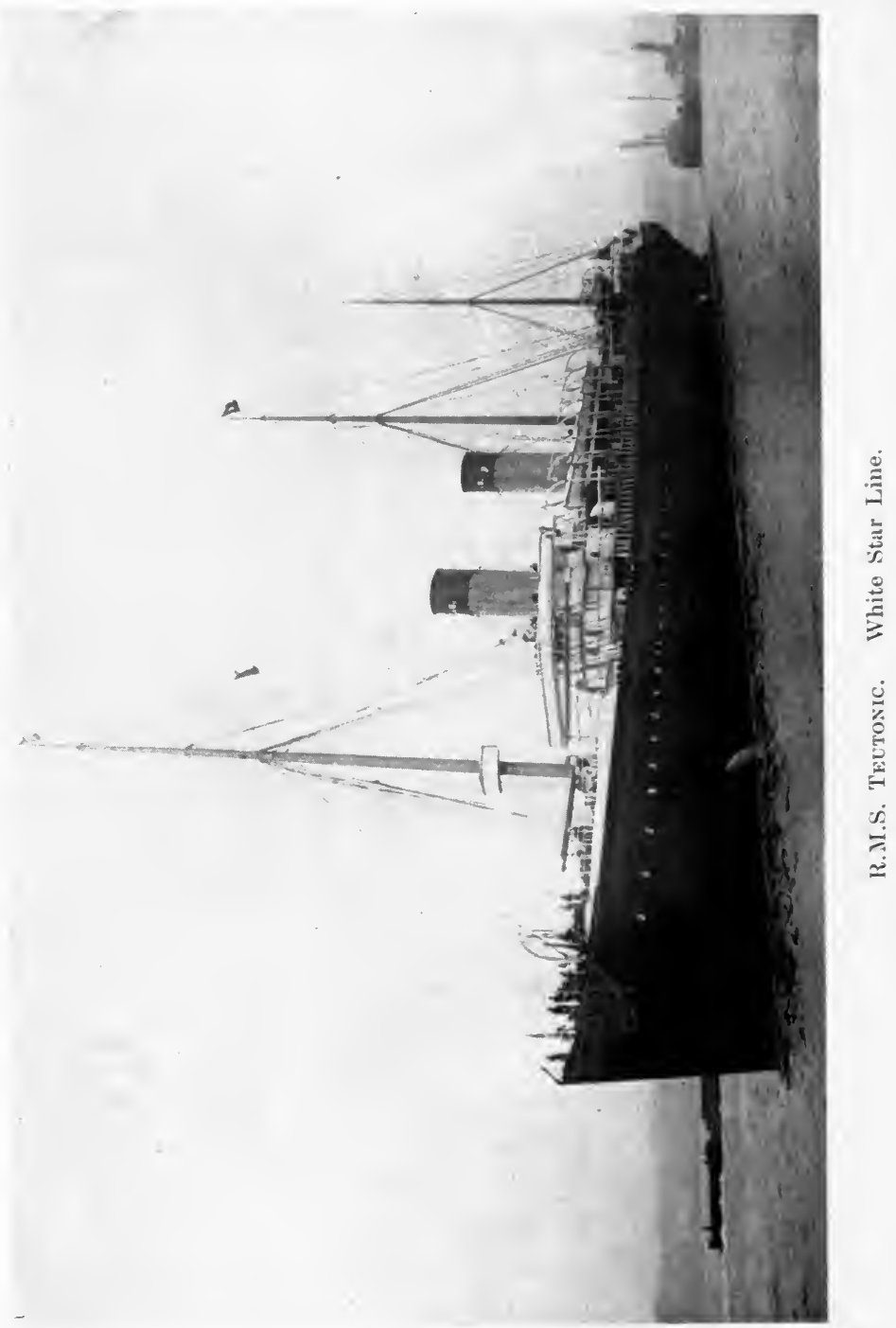


On January 1st, 1891, Mr. Ismay's two elder sons, Mr. J. Bruce Ismay (previously the company's agent in New York) and Mr. James H. Ismay, were admitted members of the firm. After 40 years' business life Mr. T. H. Ismay, on the 31st December, 1891, retired from the firm of Ismay, Imrie \& Co., but he continued to fill the position of chairman of the White Star Line until his decease in November, 1899.

A large and handsome twin-screw passenger and mail steamer, the Goтnic, of 7,755 tons, was added to the company's New Zealand fleet in 1893, and four years later (1897) the Delphic, 8,273 tons, a twin-screw cargo steamer, with accommodation for one class of passengers only, was placed in the New Zealand service.

Recognising that very considerable numbers of passengers are willing to sacrifice speed to comfort and safety, the managers of the White Star Line determined to make an innovation by building a twin-screw cargo steamer of exceptional size and power, fitted with accommodation for a limited number of saloon and third-class passengers. The new steamer which was called the CyMric, commenced work in the Liverpool and New York trade in 1898. Her tonnage is 13,096 tons gross. Her passenger accommodation in both classes is excellent, and she has proved a very attractive ship.

The autumn of 1899 was the most eventful period in the history of the White Star Line. The Company, having sold all its sailing ships formerly employed between England and Australia, determined upon replacing them by a line of highclass steamships, and the first steamer of the new line-the MEicic, 11,984 tons-sailed from Liverpool for Australian ports on the 3rd August. She was followed by the Arric, Persic, RuNic and Suevic. All these five vessels are approximately of the same size, propelled by twin screws, and maintain a regular monthly service between Liverpool and Australia, via the Cape. The first return voyage of the MEDIC was taken advantage of by the Australian Government for the conveyance of the first contingent of Colonial troops and horses to the Cape. Intense public interest was excited by the arrival in the Mersey from Belfast of the (CEanic, the second, on Saturday, 27th August, 
1899, but almost at the moment of their greatest triumph the White Star Line suffered the irreparable loss of the founder of the Company. Mr. T. II. Ismay passed away, after a severe illness lasting three months, on the 23 rd November, 1899. The extent of the loss caused by his death to the community at large, was very feelingly expressed by the "'limes," in its issue of the following day.

The second OcEanic sailed on her maiden voyage from Liverpool to New York on the 6th September, 1899. The following description of her appeared in the "Liverpool Daily Post" of 31st August, 1899 :-

"Big as she is, the OcEnNic appeared nothing remark"able as she lay yesterday in the Canada Dock, “ while coal was being poured into her bunkers from eight "grimy barges lying alongside. This was because the "Liverpool docks are themselves gigantic. It was only " when, from the bridge of the OCEANic, 66 feet above the "water-line, one looked down upon the whole length of " the vessel and upon the expause of docks and sheds, that " her size was realised. On the opposite side of the dock " was the Crmpic, from the depths of which a horde of "labourers were discharging cargo. Now the Crmric is " the largest cargo steamer in the world, 2,500 tons larger " than either the Majestic or Teutosic. But from the “Oceanic's bridge she looked positively like a coaster. "One looked down upon her busy decks as one might look "from the roof of a house into a street. Why the bulk "of the OcEanic is not the first thing that strikes the " attertion, is because her lines are graceful. She is huge, " but she is not elephantine. Her masts, even at the point " where they enter the top mast or spar deck, are nearly " three feet in diameter, that is, they are as high and as " thick as patriarchal oak; but from a near distance they "look slim and tapering. The same may be said of the "ship's boats which are as big as barges. The fact is, " that everything about this latest creation of shipping "enterprise is proportioned so beautifully that the mere " hugeness of it all is only apprehended by remembering 
" such facts as, that her rudder and stern frame weigh 150

" tous; that 100 tons of cable lie coiled on her foc'sle deck;

"that she is composed of 17,000 steel plates, many " weighing from two to three and a quarter tons; that her "promenade deck is 400 feet long; and that her monster " engines can move with the power of 28,000 horses. To "look down into the engine room from the big sky-light " on the top deck is to have a glimpse into a world that " to people not used to shipping is one of strange activity; " a world where diminutive human ants are moving in a " tropical atmosphere across narrow bridges, busy pre"paring this Brobdignagian apparatus for its first "struggle with the forces of the wide Atlantic, which the "OCEanic is to cross with the speed and certainty of an " express train-the conquest of the mighty force of " matter by the mighty force of mind. . . . .

"But much has been written already of the ship as a " triumph of science; the more immediate purpose here " is to speak of her as a triumph of art, as the last thing, "so far, in the way of floating hotels .... State rooms " in scores to the right and to the left; now mahogany, " now oak; now satinwood; now a mixture of any two or " three of them, until the lavishness of everything became "surfeiting, notwithstanding that the Louis Quinze style "succeeded the Queen Anne, and the Queen Anne gave “ place to something 'too utter' in decadent sumptuous" ness. Three decks of these apartments, with lavatories " of costly marble, suites of baths, and every other

" appurtenance of physical comfort placed conveniently "here and there. It is the literal truth to say that the "Oceanic is a Hotel Cecil afloat:"

It would serve no purpose to weary the reader with a decorator's specification, but the following are the dimensions of the OcEanic, and of the principal apartments on board :-

The library, on the promenade deck, has a length of 53 feet and a width of 40 feet.

T'he saloon is 80 feet by 64 feet. The central glass dome is 


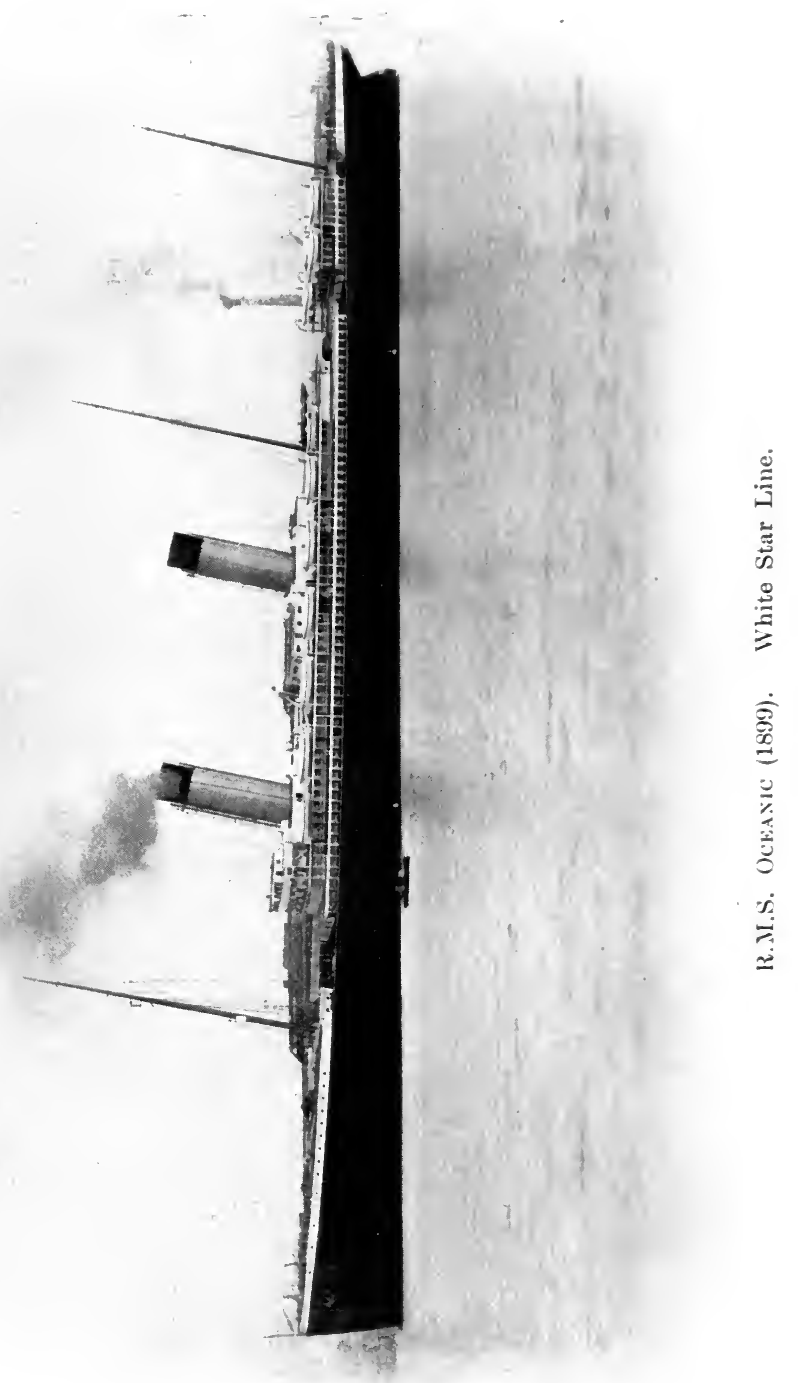


21 feet square, and is divided up by golden ribs and filled in with white ground glass of a pearly appearance.

The length of the ship over all is $705 \frac{1}{2}$ feet; the length between perpendiculars, 685 feet; breadth, 68 feet; depth, 44 feet; gross tonnage, 17,2r4 tons; load displacement, 28,000 tons; engines, 28,000 I.H.P.

Mr. Harold Arthur Sanderson, who had occupied the position of general manager to Ismay, Imrie \& Co. for five years, was admitted a partner on the 1st January, 1900.

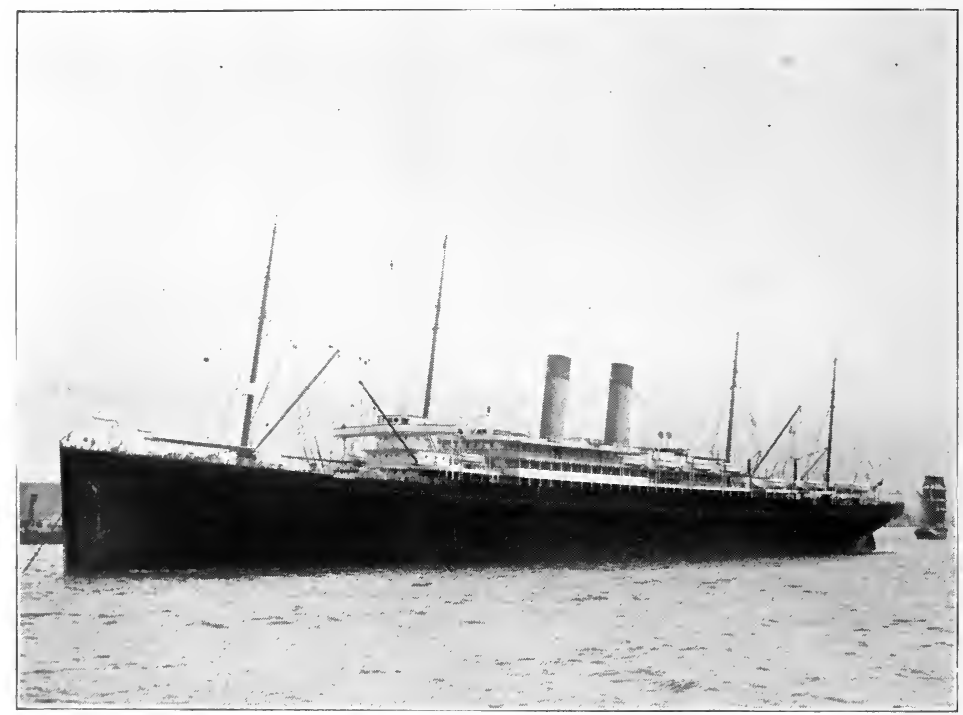

R.M.S. Centic. White Star Line.

The Celitic, a monster steamer of 20,904 tons gross, was added to the fleet in 1901. A sister ship to the Cestric was launched at Belfast on the 21st August, 1902. The new vessel is named the CEDrIC, and has the distinction of exceeding in size anything afloat, British or foreign. Like the Cestric, she is classed as an intermediate ship, not so fast as the OcEAnIc, but yet speedy. Her length is 700 feet and her beam 75 feet, with a gross tonnage of 21,000 tons. She sailed on her first voyage from Liverpool on the 11th February, 1903. 


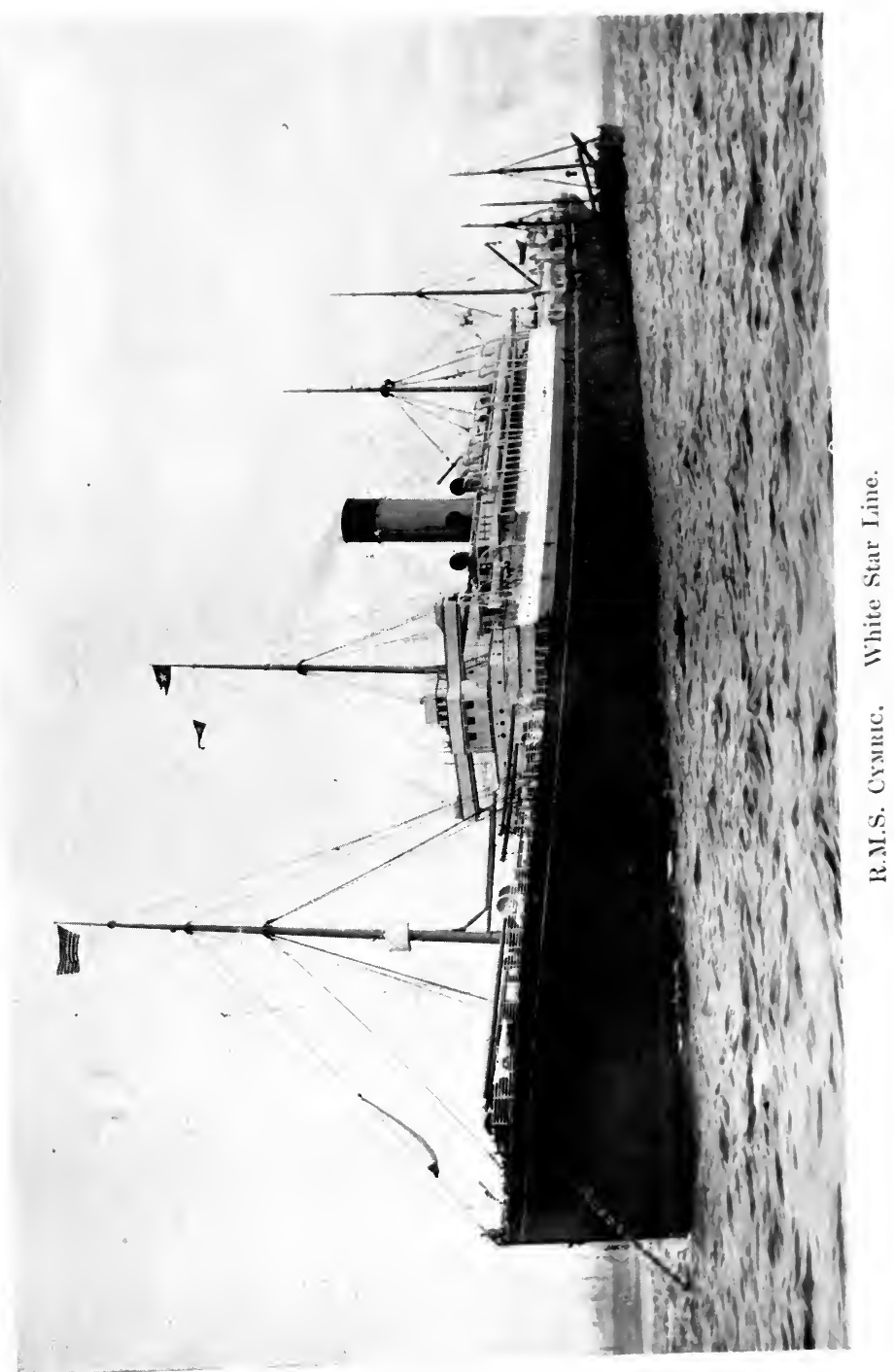


In 1902 Mr. J. P. Morgan succeeded in welding into one huge commercial undertaking, with a capital of $£ 32,000,000$, several of the principal Transatlantic steamship companies, including the famous White Star Line. The purchase money for the latter alone exceeded ten millions sterling, three millions of which was payable in cash on the 31st December, 1902 , and, as a matter of fact, was actually paid at the offices of Messrs. J. P. Morgan \& Co., in London, on the 1st December, 1902.

It was a sincere satisfaction to the British public when it was officially intimated that the White Star flag was still to be retained, and that Mr. J. Bruce Ismay and Mr. Pirrie (the senior partner of the celebrated Belfast shipbuilding firm) were to be on the directorate.

The latest addition to the New York service of the White Star Line is the Arabic, 15,800 tons gross register, which sailed on her maiden voyage, June 26th, 1903, and in the autumn of 1903 the four latest steamers built for the Dominion Line, the Columbus, Commonwealth, New England and Mayflower, were transferred to the White Star flag, and renamed the Republic, Canopic, Romanic and Cretic. With the addition of these vessels, a new service has been announced of sailings between Boston and the principal ports in the Mediterranean, and, in conjunction with the other steamships, the Crmric is intended to maintain a LiverpoolBoston service.

A monster steamer of no less than 24,000 tons (an increase of 3,000 tons upon the CEDRIC's tonnage) is approaching completion at the yard of Harland \& Wolff. She is to be named the BALTIC, and will probably be ready early in the summer of 1904. 


\section{Chapter XXI.}

Adelaide Steamship Co., Limited.-John Bacon, Limited.-R. Burton \& Sons, Limited.-Fletcher, Woodhill \& Co.—T. \& J. Harrison.-W. S. Kennaugh \& Co. -Lamport \& Holt.-H. \& W. Nelson.-R. \& J. H. Rea.-J. S. Sellers.Henry Tyrer \& Co.

The following firms hold a prominent position in their respective trades-Foreign and Coastwise-and most of them have been established for many years:-

The Adelaide Steamship Co., Lim., was established in October, 1875 , its nominal capital being $£ 100,000$. In November, 1882, the capital of the Company was increased to $£ 300,000$, and in December, 1900, a further reconstruction of the Company occurred, the capital being increased to $£ 750,000$. The first two steamers built for the Company were the Soutu Australian and the Victorian. Each was slightly over 400 tons register, making a total of 900 tons; whereas the present capacity of the Company's fleet (consisting of 25 steamers) is about 50,000 tons. The steamers, on their various routes, trade to and from nearly every port on the Australian seaboard. Amongst the vessels owned by the Adelaide Steamship Co. is the FErRer, whose romantic story is told in the first part of this volume. (See ante, page 137).

John Bacon, Lim.-This firm was established about the middle of the last century by the late Mr. John Bacon. Mr. Bacon died in 1886, and three years later the business was formed into a Limited Company. The fleet of the Company at the present date consists of the steamers Edex Valie, EDith, Heptarchy, Prestonian, Stuart, Sunlight, Talbot, Tudor, 
Vigilant, and Wexford. These steamers maintain regular sailings between Liverpool and Wexford, Liverpool and the Bristol Channel Ports, \&c.

R. Burton \& Sons.-The firm of R. Burton \& Sons was founded by the late Mr. R. Burton, of Newport, Mon., over one hundred years ago, and since 1840 has been carried on by his three sons. In 1898 the business was transferred to a Limited Company, with a capital of $£ 100,000$, the major portion of the shares being retained by the Messrs. Burton. The Company maintains regular services between Liverpool and various ports in the Bristol Channel, a daily service between Bristol and Cardiff, and a daily service between Bristol and Newport, Mon.

Fletcher, Woodhill \& Co.-This firm was established et Manchester, in 1893, by Mr. H. A. Fletcher (of Liverpool) and Captain T. J. Woodhill (of Sunderland). Since the opening of the Ship Canal Messrs. Fletcher, Woodhill \& Co. have taken an active part in the steamship business of the port of Manchester. Their present services are between Manchester and France; Manchester, Portugal and Spain; and Manchester and Italy.

T. \& J. Harrison.-This important Steamship Company maintains regular sailings from Liverpool to Calcutta, New Orleans, Galveston, Brazil and West Indies, and South of France; also joint sailings of Ellerman-Harrison Line from Glasgow and Liverpool to South and East Africa. The fleet at the present date (1904) consists of 36 full-powered steamships, exclusive of two steamers building, with an aggregate gross tonnage of 179,166 tons:-Actor, Barrister, CapellaA, Cinamcellor, Civilian, Cognac, Collegian, Colonial, Comediax, Counselior, Craftsman, Custodiax, Dictator, I) irector, Electrician, Explorer, Historian, Inventor, Jarnac, Logician, Magician, Mechanician, Mira, Musiclan, Navigator, Orion, Patrician, Politician, Senator, Statesman, Tactician, Traveller, Wanderer, Wayfarer, WorkMaN, Yeoman. 
W. S. Kennaugh \& Co. commenced business of steamship owners at a time when sailing vessels were being displaced in the general coasting trade by steamers. The first boat built for the firm was the Scale Force, famous in her day for her large carrying powers on a low net register. She was designed by a brother of the senior partner of the firm, by whom all the succeeding steamers have been designed. The names of the steamers at the present date owned by this firm are the Arra Force, Birker Force, Holme Force, and Stanley Force.

Lamport \& Holt Line.-The Liverpool, Brazil and River Plate Steam Navigation Co., Limited, better known as the "Lamport \& Holt" Line, was formed in 1865, the first Managers of the Line being the late Mr. William James Lamport, and Mr. George Holt. This Company is one of the largest of the Steamship Companies of Liverpool, at which Port its headquarters are situated. It owns a fleet of thirty-nine full-powered modern eargo steamers, ranging from 1,671 tons to 6,508 tons, the average per steamer being 3,375 tons and the aggregate tonnage 131,654 tons gross register, representing a total dead weight carrying capacity of about 200,000 tons.

The Company has given special attention to the transit of cattle to and from the River Plate, in which trade it has nine steamers, specially built for this service, having permanent fittings for the conveyance of live-stock.

These vessels have a most satisfactory record for the carriage of the cattle shipped by them. Live stock are also carried between New York and Manchester by boats specially adapted to the requirements of the North Atlantic Trade.

All the steamers of the Lamport and Holt fleet are fitted with the most modern appliances for the rapid and effective handling of general cargo. The operations of the Company are varied and extensive and comprise the following regular services:From Glasgow, Mauchester and Liverpool to Bahia, Rio de Janeiro and Santos, fortnightly. From London and Antwerp to Rio de Janeiro and Santos, every ten days. From New York (carrying first and third-class passengers) to Pernambuco, Bahia, Rio de Janeiro and Santos, fortnightly. Also to the 
River Plate from Liverpool, fortnightly; from Glasgow, monthly; from London and Antwerp, fortnightly; and from New York at frequent intervals. A regular monthly service is also maintained between Liverpool, Glasgow, and West Coast ports in Chili, Peru, and Ecuador.

The steamers of this Line have always been very popular with shippers, who are able to depend upon regularity of service, and careful handling of their goods.

H. \& W. Nelson, Limited.-This remarkably successful Company was founded in 1889, by Messis. Hugh and William Nelson.

The pioneer steamer of the fleet was the steamer Spindrift, now the Highland Scot, which sailed from Liverpool on her maiden voyage on the 12 th December, 1889.

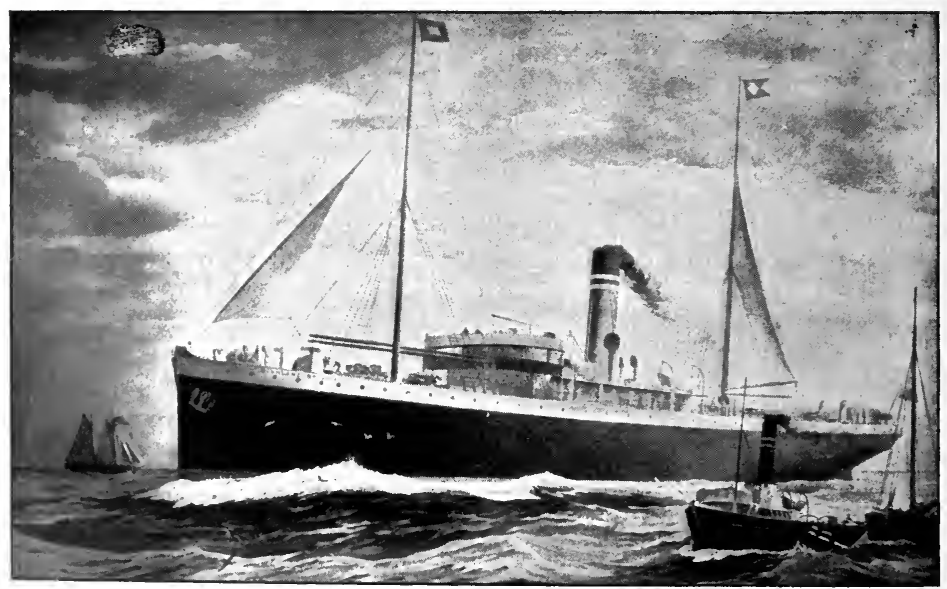

Highland Brigade s.s. H. \& W. Nelson, Limited.

A few months later (May, 1890) the second steamer of the line, the Higmlaxil Chief, was launched, and the following year three additional steamers were built for the Company, and named respectively the Higimland Glen, Highland Lassie and Highlani Mary. 
Since that date, nine vessels (including three now building) have been added to the fleet, which consists of fourteen powerful modern steamships of large carrying capacity. These steamers are all very similar in design (though several are much larger) to the Highland Exterpirise, of which particulars are given below.

The Highlaxd Exterprise was launched in January of the present year (1903). She is 385 feet long, between perpendiculars; with 45 feet beam, and draft laden $2: 3$ feet $(5$ inches. She has a carrying capacity of 6,500 tons. Like her sister ships, she is insulated throughout for carrying frozen meat, and fitted with the latest type of refrigerating machinery, as well as the most up-to date appliances for the effective handling of general eargo. Accommodation has been provided amidships for about a dozen passengers. Her engines, which are of the tripleexpansion type, propelled her on her trial trip at a speed equal to $13 \frac{3}{4}$ knots per hour.

In addition to a regular fortnightly service between Liverpool and Monte Video, Buenos Ayres and Rosario, the steamers of the Nelson Line sail at regular monthly intervals from London and Newport (Mon.) to the River Plate.

\begin{tabular}{|c|c|c|c|c|}
\hline 8 & & $\mathrm{~F}_{\mathrm{L}}$ & & \\
\hline HighLAND & BRIGADE & $\begin{array}{l}\text { Tons Reg. } \\
\ldots .5,640\end{array}$ & Highlaxd Heather & $\begin{array}{l}\text { Tons Reg. } \\
\text {.. } 5,500\end{array}$ \\
\hline HIGHLAND & Сhief... & $\ldots 2,640$ & Highlaxid Hope... & $\ldots 4,500$ \\
\hline HighLAND & Corrie & $\ldots 4,050$ & Highlaxd Laird... & $\ldots 4,116$ \\
\hline HighLAND & ENTERPRISE & ... 4,500 & Highland Lassif: & $\ldots 2,488$ \\
\hline HighLAND & GHILLIE & .. 3,935 & Highlanid Mary ... & $\ldots 2,974$ \\
\hline HIGHLAND & GLEN ... & $\ldots 2,974$ & HIGHLAND SCOT ... & ... 3,060 \\
\hline HighLAND & HaRRIS & $\ldots 5,500$ & Highland Watch & $\ldots 5,500$ \\
\hline
\end{tabular}

R. \& J. H. Rea.-In 1872 Mr. Russell Rea (the present M.P. for the (ity of Gloucester), commenced business as a coal merchant in Liverpool. After a lapse of seven years (18i9), he admitted his brother, Mr. James Rea, into partnership, and the style of the firm was altered to R. \& J. H. Rea. The firm own a fleet of five powerful modern eoasting steamers, each having a capacity of about 2,500 tons dead weight, and 
named respectively the Bangarth, Calgarth, Dalegarth, Gatesgarth, and Throstlegarth. In addition to these vessels, the firm possesses five steam tugs and about 200 lighters. Messrs. R. \& J. H. Rea have offices at London, Liverpool, Southampton, Bristol and Cardiff.

John S. Sellers-Mr. Sellers commenced business as a steamship owner at Liverpool in the early nineties, the first steamer acquired by him being the Тıмво. Although for a short time employed as a "tramp" she was soon placed in a regular general cargo trade, and during the past ten years she has maintained, with every satisfaction to shippers and consignees, the service between Liverpool and Preston. Mr. Sellers has also established a regular trade between Harlingen (Holland) and Liverpool, and since early in 1900 he has built up a regular weekly service between Glasgow and Preston, which is well served by the Thursiy and other steamers.

Henry Tyrer \& Co.-Mr. Henry Tyrer, the sole partner in this firm, commenced business in 1878, in Liverpool, and in 1892 opened a branch office at Preston. The Albert Edward Dock at Preston, was opened by the late Duke of Edinburgh in June of that year, and immediately after the opening ceremony, the steamer LAdy Louisa, chartered by Messrs. Henry Tyrer \& Co., commenced discharging, being thus the first steamer to unload in Preston Dock. This firm has continued from that date to be closely associated with the steam trade of Preston. In 1899 Messrs. Henry Tyrer \& Co. built the steamer Prestonian, the first steamer to bear that name, shortly afterwards disposing of her to Messrs. John Bacon, Limited, in whose service she is still employed. The following year (1900) Messrs. Henry Tyrer \& Co. purchased the steamship HERMAN, of about 1,300 tons deadweight, which is regularly employed in the firm's wood pulp trade from Baltic ports. The small steamer Princess was purchased the same year for employment in the firm's regular London and Preston general cargo trade. In 1901 the steamer Prestonian, the first, was replaced by a new steamer of 1,600 tons deadweight, also 
named the Prestoxian, and which, like the Hzrmaxs, is regularly engaged in the firm's wood pulp trade.

During the present year (1903) the firm bought the steamer Minterse, and re-named her the Naxcy Lez. She is a large steamer of about 4, 750 tons deadweight, and has proved herself to be an excellent sea boat. A remarkable incident in connection with this ship is, that she has been chartered for six years, to run consecutive voyages between the Saguenay River (Canada) and the U. K., at a fixed rate of freight covering the whole period. In addition to their offices at Liverpool and Preston, Messrs. Henry Tyrer \& Co. have also branch oftices at London and Manchester, in connection with their extensive and largely developing wood pulp trade.

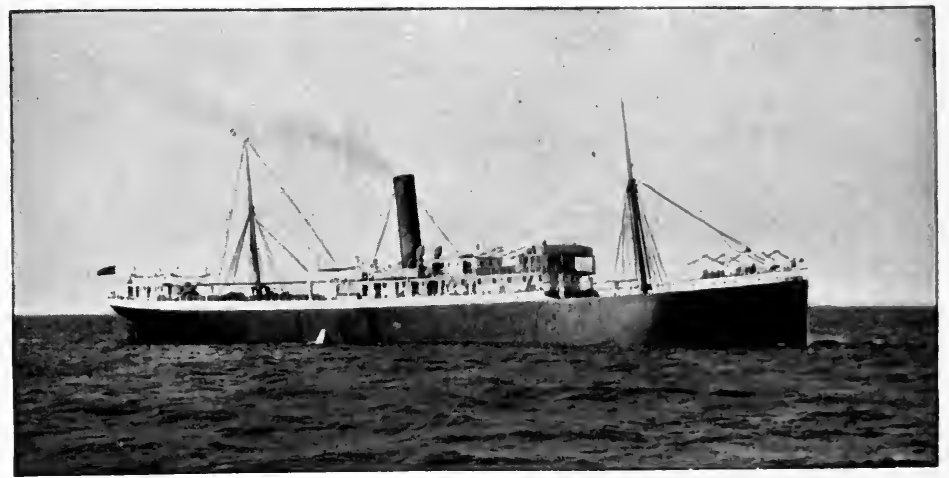





\section{I.N D E X .}

AARON MANBY (1822), first iron steamboat $\ldots \quad \ldots \quad \ldots \quad \ldots \quad \ldots . \quad \ldots \quad \ldots 9$

Abbé Arnal and Marquis de Jouffroy $\left(\begin{array}{llllllll}1781) & \ldots & \ldots & \ldots & \ldots & \ldots & 3\end{array}\right.$

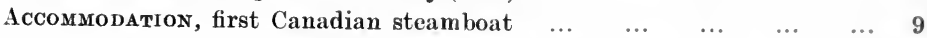

Achilles (Holt Line), Remarkable steaming powers of $\ldots \quad \ldots 136$

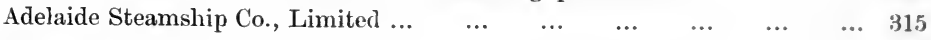

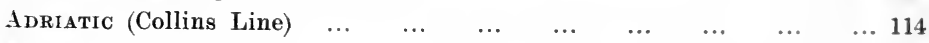

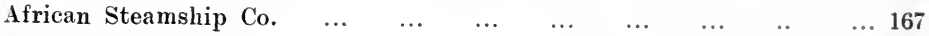

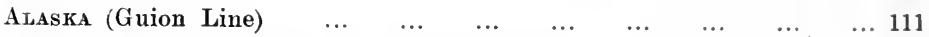

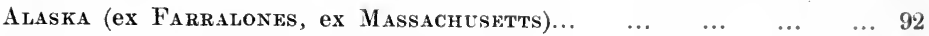

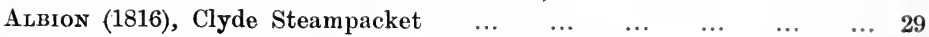

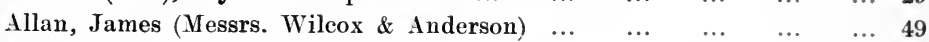

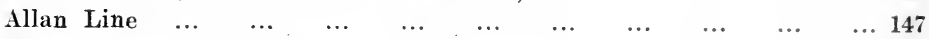

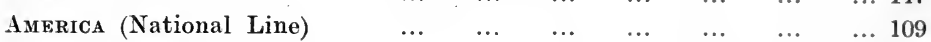

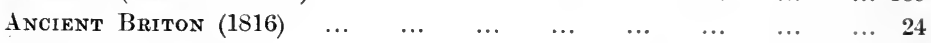

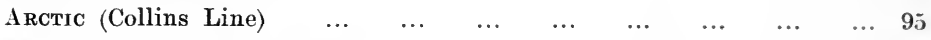

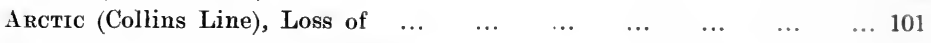

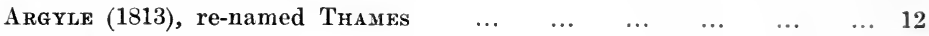

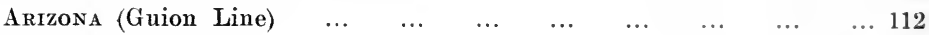

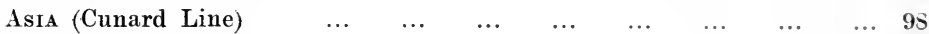

$\begin{array}{llllllllllll}\text { Atalanta } & (1836) & \ldots & \ldots & \ldots & \ldots & \ldots & \ldots & \ldots & \ldots & \ldots & 49\end{array}$

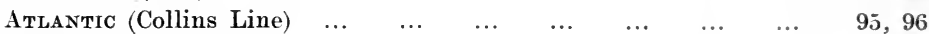

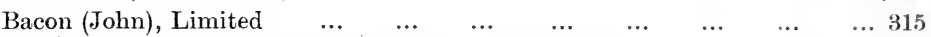

Battic (Calcutta and Burmah Steam Navigation Co.) $\quad \ldots \quad \ldots \quad \ldots \quad \ldots 5$

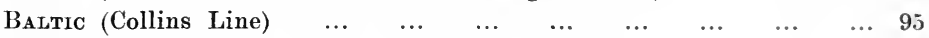

Belfast, First steamer to and from Greenock and ... $\quad \ldots \quad \ldots \quad \ldots \quad \ldots \quad 26$

Belfast, First steamer to and from Liverpool and $\ldots \quad \ldots \quad \ldots \quad \ldots \quad \ldots 33$

Belfast Steampacket Co., established $\ldots \begin{array}{llllllll} & \ldots & \ldots & \ldots & \ldots & \ldots & 40\end{array}$

Bell, Henry, present at Mr. Miller's experiments in $1789 \ldots \quad \ldots \quad \ldots \quad 6$

- gives Fulton the plans of the Charlote Dindas, 1803 .

employs the steamer Coмeт on the Clyde, $1812 \quad \ldots . \quad \ldots \quad \ldots \quad 11$

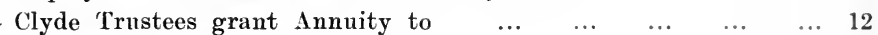

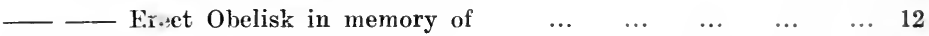

$\begin{array}{llllllllllll}\text { BerENICE } & (1836) & \ldots & \ldots & \ldots & \ldots & \ldots & \ldots & \ldots & \ldots & \ldots & 49\end{array}$

$\begin{array}{llllllllll}\text { Bibby Bros. \& Co., founded } 1807 & \ldots & \ldots & \ldots & \ldots & \ldots & \ldots & 56\end{array}$

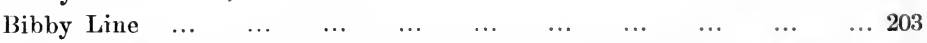

Birminghaм (City of Dublin Co.) brings news of defeat of Don Miguel... 64

Bourne, Messrs., establish steamship service to the Peninsula ... $\quad \ldots \quad 49$

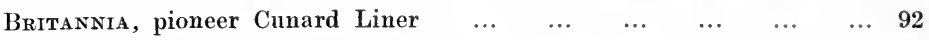

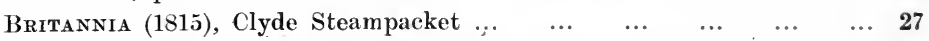

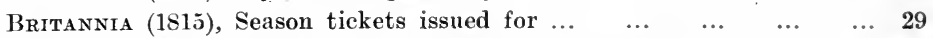

British and African Steam Navigation Co., Limited $\ldots \ldots \ldots 170$

British and Irish Steampacket Co., Limited $\ldots \quad \ldots \quad \ldots \quad \ldots \quad \ldots \quad \ldots 195$

British India Steam Navigation Co. $\ldots \begin{array}{llllllll} & \ldots & \ldots & \ldots & \ldots & \ldots & 55\end{array}$ 
British Queen Steam Navigation Co. $\ldots \begin{array}{llllllll} & \ldots & \ldots & \ldots & \ldots & \ldots & 70\end{array}$

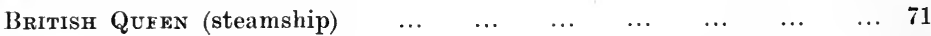

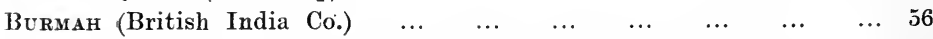

Burns, G. and J., commence business as steamship owners $\quad \ldots \quad \ldots \quad 42$

$\begin{array}{lllllllllll}- \text { first steamer } & \mathrm{AYR}, 1825 & \ldots & \ldots & \ldots & \ldots & \ldots & \ldots & \ldots & 43\end{array}$

— despatch steamer Fingal, Glasgow to Belfast, $1826 \ldots \quad \ldots \quad \ldots \quad \ldots 43$

— enter the Liverpool and Glasgow trade, $1829 \ldots \quad \ldots \quad \ldots \quad \ldots \quad \ldots 43$

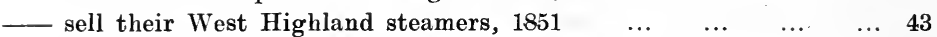

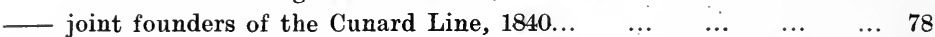

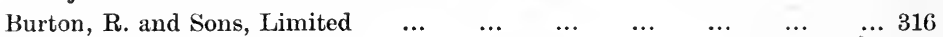

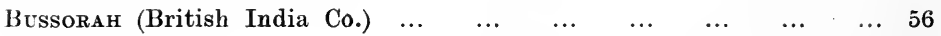

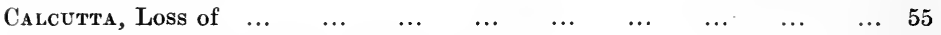

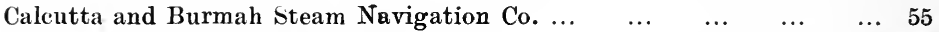

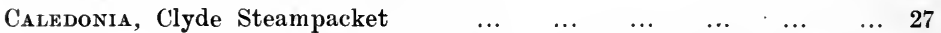

Caledonia, Clyde Steampacket (Quotation from "Life of Watt") $\ldots 29$

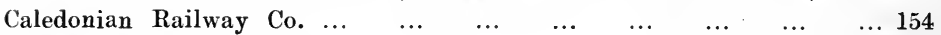

$\begin{array}{lllllllll}\text { Canadian Pacific Railway Co. } & \ldots & \ldots & \ldots & \ldots & \ldots & \ldots & \ldots & 150\end{array}$

$\begin{array}{lllllllll}\text { CAPE of Good Hope, Loss of } & \ldots & \ldots & \ldots & \ldots & \ldots & \ldots & \ldots & 55\end{array}$

$\begin{array}{llllllllll}\text { Car of Commerce }(1813) & \ldots & \ldots & \ldots & \ldots & \ldots & \ldots & \ldots & \ldots & \ldots \\ \end{array}$

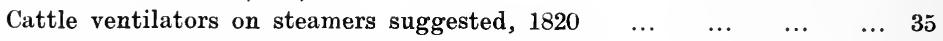

$\begin{array}{lllllllllll}\text { Charlotte Dundas }(1803) & \ldots & \ldots & \ldots & \ldots & \ldots & \ldots & \ldots & 5\end{array}$

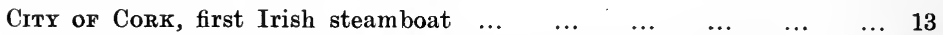

City of Dublin (1823), pioneer steamer of the City of Dublin Co. ... 40

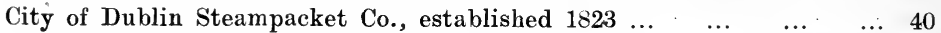

— establish regular steampacket service between England, Ireland

$\begin{array}{lllllllll}\text { and France, } 1827 & \ldots & \ldots & \ldots & \ldots & \ldots & \ldots & \ldots & 44\end{array}$

$\begin{array}{llllllllll}\text { History of } & \ldots & \ldots & \ldots & \ldots & \ldots & \ldots & \ldots & \ldots & \ldots \\ \end{array}$

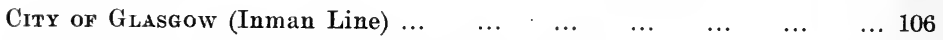

Cllermont, first passenger steamer in the world $\ldots \begin{array}{llllll}\ldots & \ldots & \ldots & \ldots & 7\end{array}$

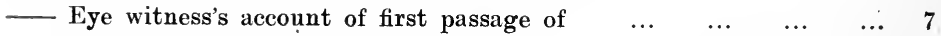

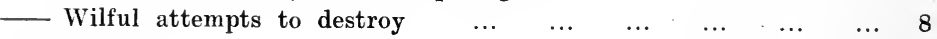

$\begin{array}{llllllllllll}\text { Collins Line } & \ldots & \ldots & \ldots & \ldots & \ldots & \ldots & \ldots & \ldots & \ldots & \ldots & 94\end{array}$

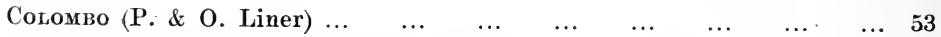

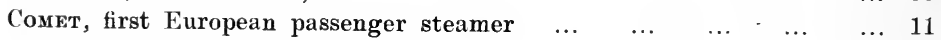

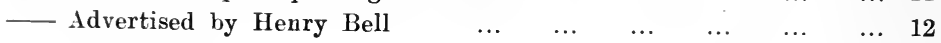

$\begin{array}{lllllllllll}- \text { Dimensions of } & \ldots & \ldots & \ldots & \ldots & \ldots & \ldots & \ldots & \ldots & 12\end{array}$

$\begin{array}{lllllllll}- \text { Amusing anecdote relating to } & \ldots & \ldots & \ldots & \ldots & \ldots & \ldots & 12\end{array}$

Conde de Patmella, probably the first steamer to cross the Atlantic

$\begin{array}{lllllllllll}\text { from Europe } & \ldots & \ldots & \ldots & \ldots & \ldots & \ldots & \ldots & \ldots & 3 \tilde{5}\end{array}$

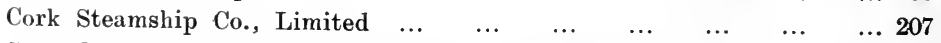

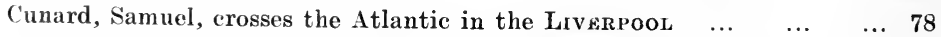

— tenders for British and North American Mail Service $\quad \ldots \quad \ldots 78$

conjointly with Messrs. Burns \& MacIver, founds the Cunard Line 78

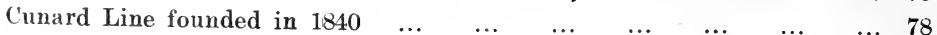

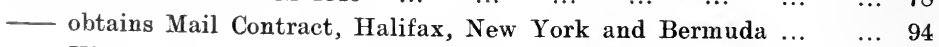

\begin{tabular}{l} 
History of \\
\hline
\end{tabular}

DEFIANCE (1815), Thames Steampacket $\quad \ldots-13,23$ 
De Garay (1543), Alleged invention by

Dodd, Captain

Dublin and Liverpool Steam Navigation Co., established $1824 \ldots \ldots \quad \ldots \quad 40$

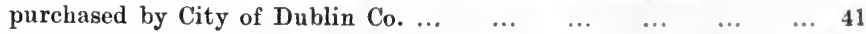

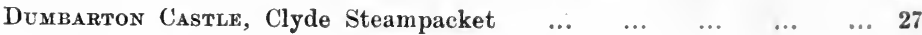

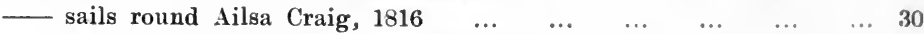

sails round North of Scotland, $1819 \quad \ldots \quad \ldots . \quad \ldots \quad \ldots \quad \ldots \quad \ldots \quad 30$

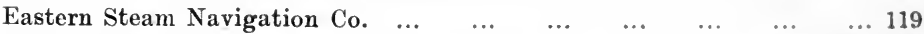

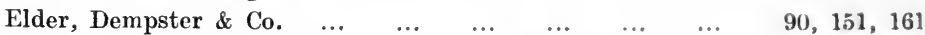

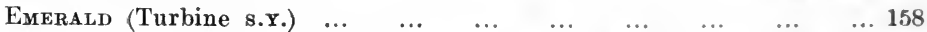

ENterprise, first steamer from England to Calcutta ... ...43, 47, 48

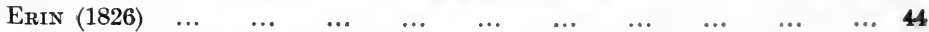

ETna, first steam ferry boat between Liverpool and Tranmere ... ... 24

Farralones, ex Massachusets, re-named Alaska ... $\ldots \ldots \ldots$... . 92

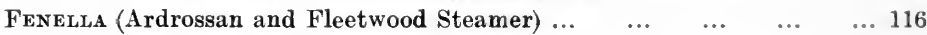

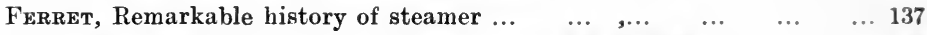

Fitch, Mr. (1783), uses steam boilers on American Rivers $\ldots \ldots$... 4

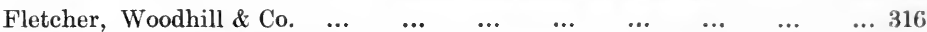

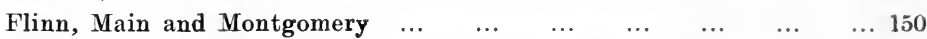

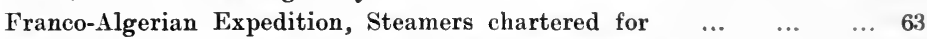

George Canning (1825), and the Rival Steampacket $\ldots \ldots \ldots \ldots$... 42

Glasgow Steampackets in $\begin{array}{rlllllllll} & 1815 & \ldots & \ldots & \ldots & \ldots & \ldots & \ldots & \ldots & 27\end{array}$

$\begin{array}{llllllllllll} & \text { in } 1818 & \ldots & \ldots & \ldots & \ldots & \ldots & \ldots & \ldots & \ldots & \ldots & 31\end{array}$

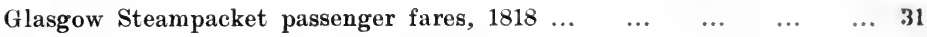

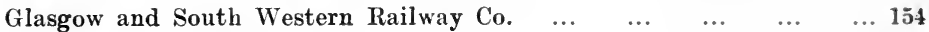

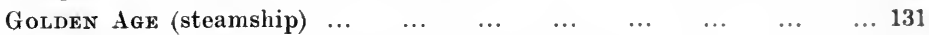

Great Britain (steamship), in the Atlantic trade $\ldots \quad \ldots \quad \ldots \ldots \quad \ldots \quad 81$

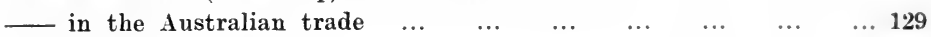

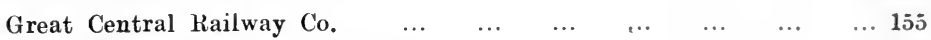

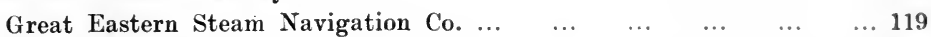

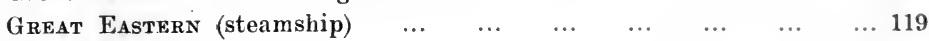

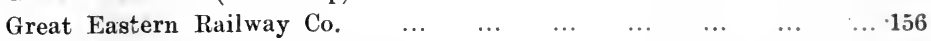

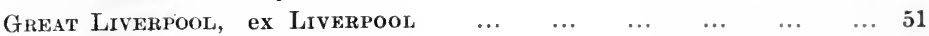

Great Western Steamship Co.

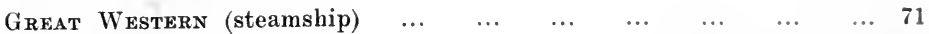

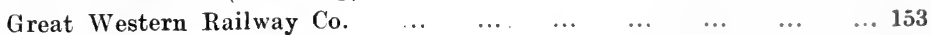

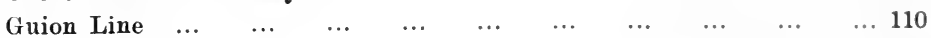

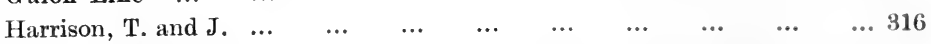

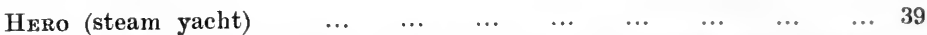

Hibernia (1816), first steamer between England (Holyhead) and Ireland

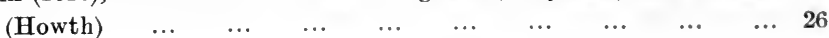

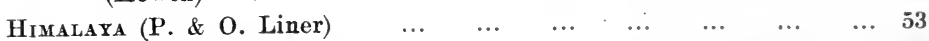

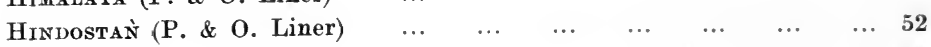

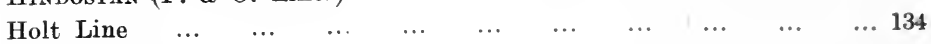

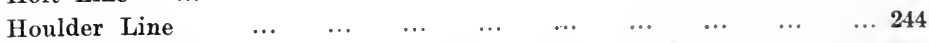

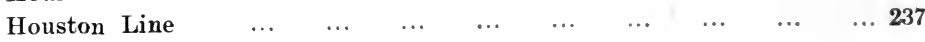




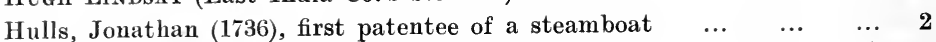

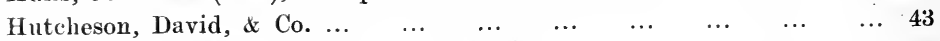

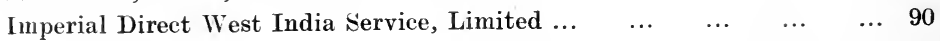

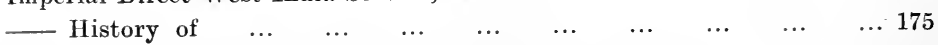

INDIA, first steamer with Indian produce via Suez Canal $\ldots \quad \ldots \quad \ldots \quad \ldots 56$

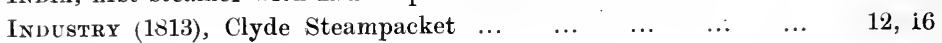

$\begin{array}{llllllllllll}\text { Inman Line } & \ldots & \ldots & \ldots & \ldots & \ldots & \ldots & \ldots & \ldots & \ldots & \ldots & 106\end{array}$

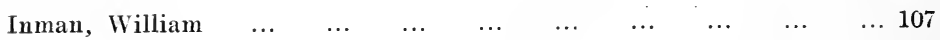

$\begin{array}{llllllllllll}\text { Irish steamers } & \ldots & \ldots & \ldots & \ldots & \ldots & \ldots & \ldots & \ldots & \ldots & 13\end{array}$

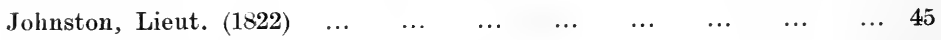

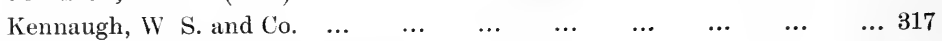

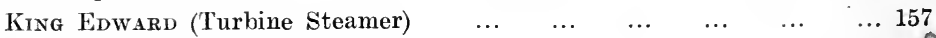

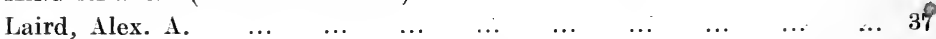

$\begin{array}{llllllllll}\text { Laird Line } & \ldots & \ldots & \ldots & \ldots & \ldots & \ldots & \ldots & \ldots & \ldots 29,37,251\end{array}$

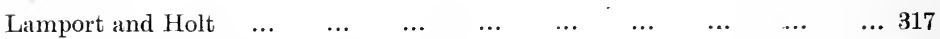

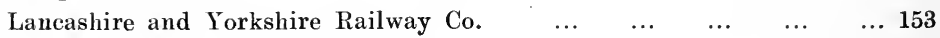

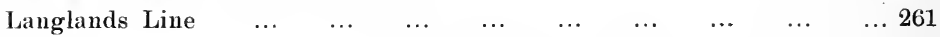

Lardner, Dr., on steam communication with America $\quad \ldots \quad \ldots \quad \ldots 68$

LEEDs, pioneer steamer between Belfast, Dublin and Bordeaux ... $\quad \ldots \quad 44$

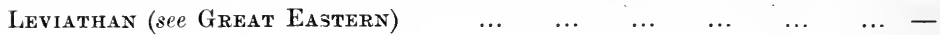

Lightning (one of the first steamships in the British Navy) . . . 40

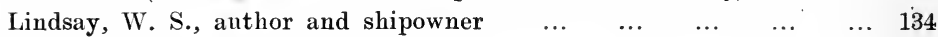

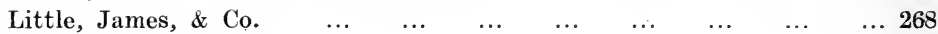

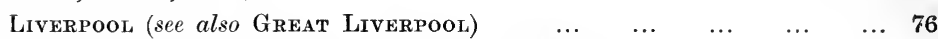

Liverpool (first steamer ever seen on the Mersey) $\ldots \begin{array}{lllll}\ldots & \ldots & \ldots & \ldots & 15\end{array}$

Liverpool steamers highly commended in Parliamentary Report, 1822.. 39

Liverpool and Kingstown Mail Service established ...

London, Brighton and South Coast Railway Co. $\quad \ldots \quad \ldots \quad \ldots \quad \ldots \quad \ldots l 152$

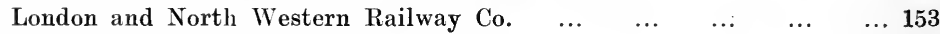

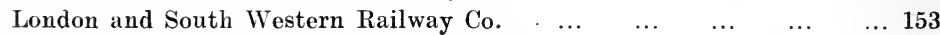

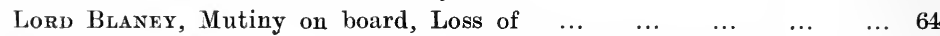

MacBrayne, Mr. David, partner in David Hutcheson \& Co. $\quad \ldots \quad \ldots 43$

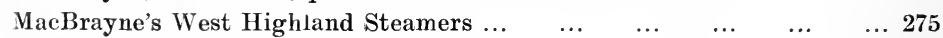

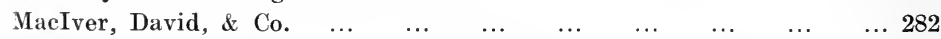

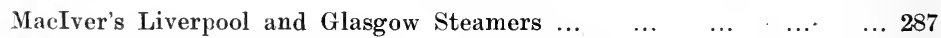

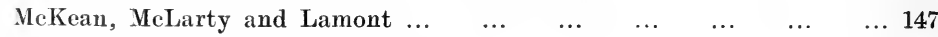

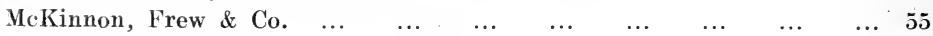

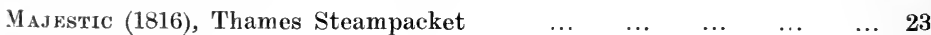

$\begin{array}{lllllllllll}\text { Malcomson Bros. } & \ldots & \ldots & \ldots & \ldots & \ldots & \ldots & \ldots & \ldots & \ldots & 113\end{array}$

MARGARET (first screw steamer belonging to Hull), Loss of $\ldots \quad \ldots 65$

$\begin{array}{lllllll}\text { M ARJORY (1015), Thames Steampacket } & \ldots & \ldots & \ldots & \ldots & \ldots & 13\end{array}$

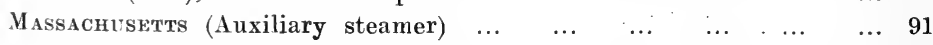

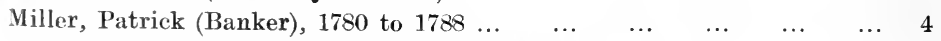

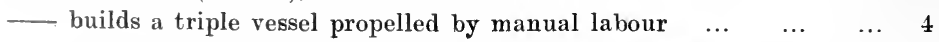

- lannches (1788) a twin steamboat on Dalswinton Loch $\ldots \quad \ldots \quad 5$

- places (1789) a larger steamboat on the Forth and Clyde Canal ... 5 
Miller dies (1815) having exhausted his fortune by experiments $\quad \ldots \quad$...

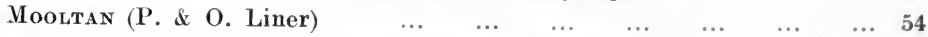

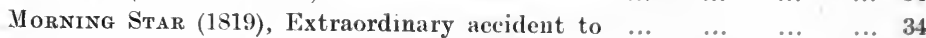

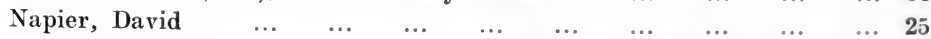

— establishes steampacket service between Greenock and Belfast ... 26

$\begin{array}{llllllllll}\text { National Line } \quad \ldots & \ldots & \ldots & \ldots & \ldots & \ldots & \ldots & \ldots & \ldots & \ldots 8\end{array}$

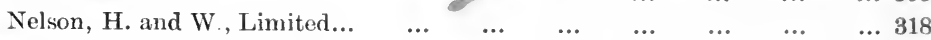

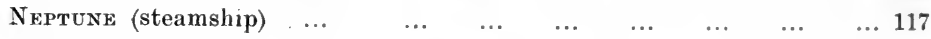

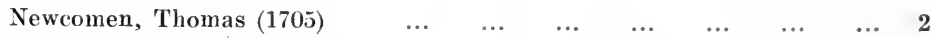

\begin{tabular}{llllllll} 
North British Railway Co. & $\ldots$ & $\ldots$ & $\ldots$ & $\ldots$ & $\ldots$ & $\ldots$ & $\ldots$ \\
\hline
\end{tabular}

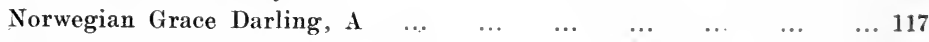

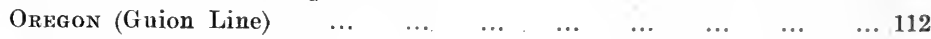

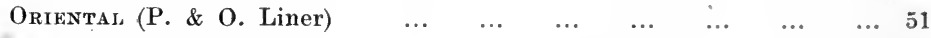

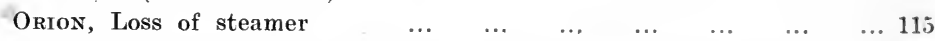

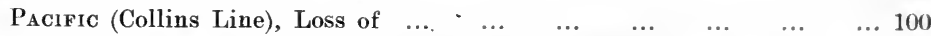

PAclfic, first Mail Steamer between Liverpool and Valparaiso ... ... 60

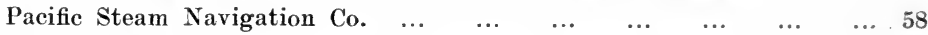

Papin (1681) $\quad \begin{array}{lllllllllll} & \ldots & \ldots & \ldots & \ldots & \ldots & \ldots & \ldots & \ldots & \ldots & 2\end{array}$

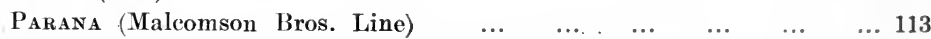

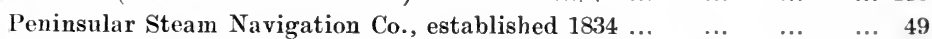

— title changed to P. \& O. Steam Navigation Co., 1838 ... $\quad \ldots \quad \ldots \quad$... 51

$\begin{array}{lllllllllll} & \text { - history of Company } & \ldots & \ldots & \ldots & \ldots & \ldots & \ldots & \ldots & 49\end{array}$

Peninsular and Oriental Steam Navigation Co. (see Peninsular Steam

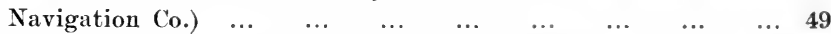

Peru, pioneer steamer of the Pacific Steam Navigation Co. $\quad . . \quad \ldots \quad 59$

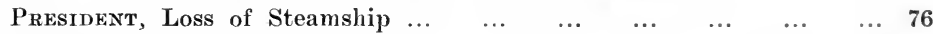

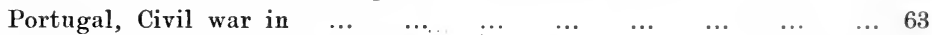

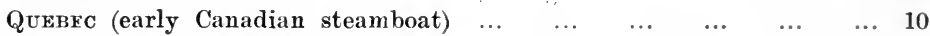

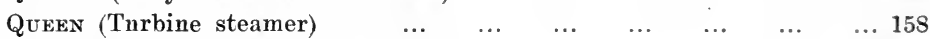

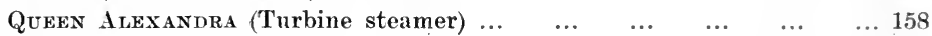

$\begin{array}{lllllllllll}\text { Rea, R. and J. H. } & \ldots & \ldots & \ldots & \ldots & \ldots & \ldots & \ldots & \ldots & \ldots & \end{array}$

REgFNT (1816), Deseription of $\begin{array}{lllllllllll} & \ldots & \ldots & \ldots & \ldots & \ldots & \ldots & \ldots & 23\end{array}$

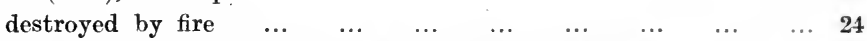

Regulator (1818), early Liverpool and Tranmere Ferry steamer ... 25

Robert Bruce (1819), first Liverpool and Glasgow stcamer ... . . 34

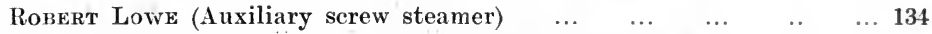

Roв Roy, first steamer between Greenock and Belfast ... $\ldots . \ldots 26$

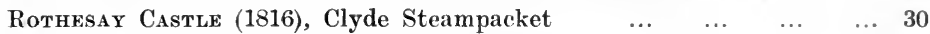

Royal Atlantic Steam Navigation Co. (Galway Line) $\quad \ldots \quad \ldots \quad \ldots 112$

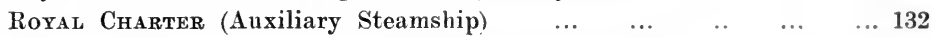

Royal Ferdinand (1817), first steamer built in Spain $\ldots \ldots \ldots \ldots$

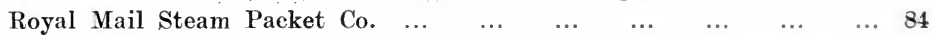

ROYAL TAR, pioneer steamer of the Peninsular Steam Navigation Co. ... 49

Royal Wrlitam (City of Dublin Co.), first Liverpool and New York Liner

Royal WILliam (of Quebec), first vessel to cross the Atlantic by steam power only 


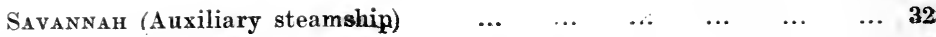

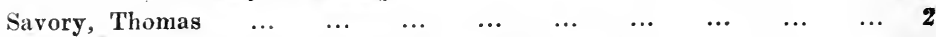

Scotland, first foreign vessel to load at Shanghai $\ldots \quad \ldots \quad \ldots \quad \ldots \quad \ldots 134$

Season Contract. Tickets (1816), issued per steamers $\quad \ldots \quad \ldots \ldots \ldots 29$

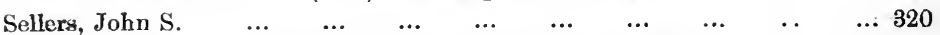

SiRIUs, first passenger steamer from Europe to America ... $\quad \ldots \quad \ldots \quad 71$

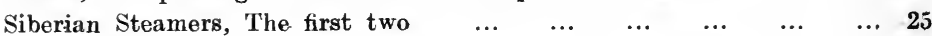

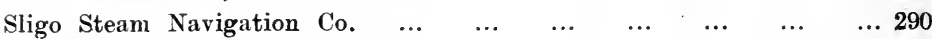

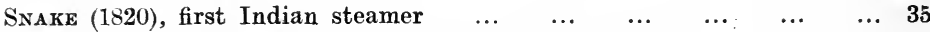

Sopнia JANe, first steamer from England to Australia $\ldots \ldots \quad \ldots \quad \ldots 129$

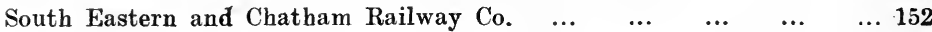

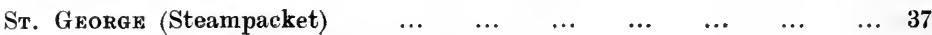

St. George Steam Packet Co., established $\ldots . \quad \ldots . \quad \ldots \quad \ldots \ldots \quad \ldots \quad 37$

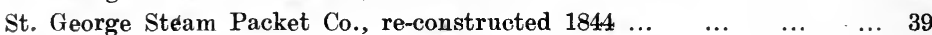

St. Patrick (Steampacket) $\quad \ldots \quad$...

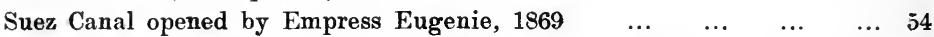

Swirr (1825), Extraordinary advertisement by owners of $\ldots \quad \ldots \quad \ldots \quad 41$

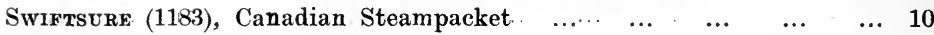

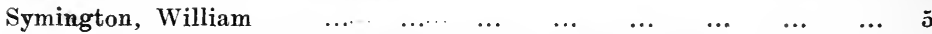

Taylor (1780 to 1788) suggests steam power to Mr. Miller $\quad \ldots \quad \ldots \quad 4$

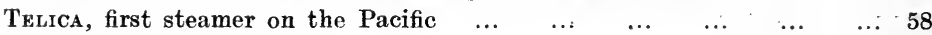

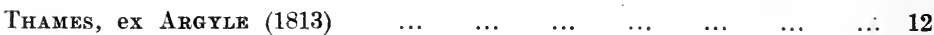

- London "Times," Notice of $\quad \begin{array}{lllllllll} & \ldots & \ldots & \ldots & \ldots & \ldots & \ldots & 13\end{array}$

$\begin{array}{lllllllllll}\text { Description of } & \ldots & \ldots & \ldots & \ldots & \ldots & \ldots & \ldots & \ldots & 16\end{array}$

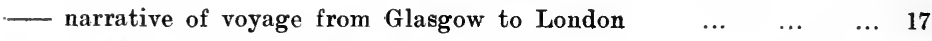

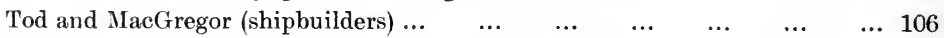

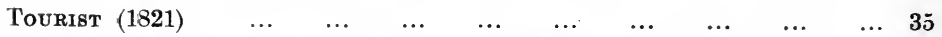

Trent R.M.s., Arrest of confederate Commissioner on board of ... $\quad . .90$

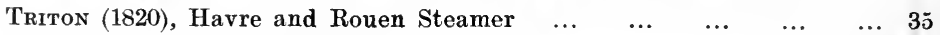

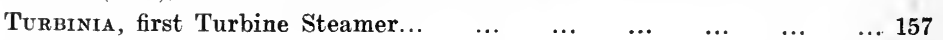

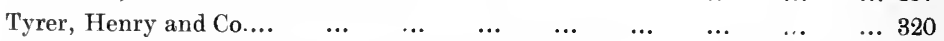

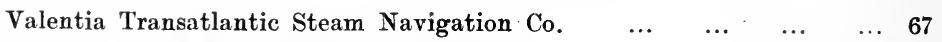

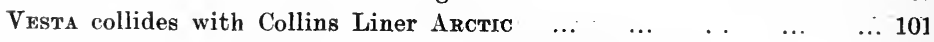

Victorian, first Transatlantic Turbine Steamship ... $\quad \ldots \quad \ldots \quad \ldots \quad \ldots 149$

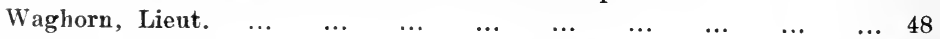

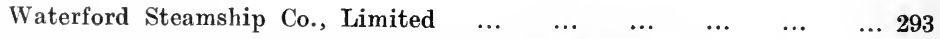

WATÉRLoo (1819), first Liverpool Cross-Channel Steamer ... $\quad \ldots \quad \ldots 33$

Wesewelodsky, Mr. (1817) builds two steamers in Siberia ... $\quad \ldots \quad$... 25

$\begin{array}{llllllllll}\text { White Star Line } & \ldots & \ldots & \ldots & \ldots & \ldots & \ldots & \ldots & \ldots & \ldots 300\end{array}$

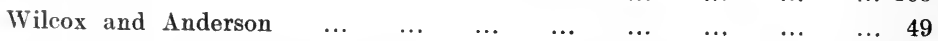

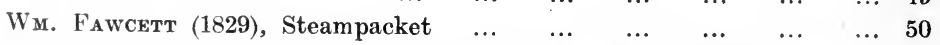

Wm. Wheelwright, promoter of steam navigation in the Pacific ... $\quad \ldots \quad 58$

Yorkshirkman (1823), first steamer from Hull to the Continent ... $\quad \ldots \quad 39$ 
ADVERTISEMENTS. 


\section{THE LARGEST FIRE OFFICE IN THE WORLD.}

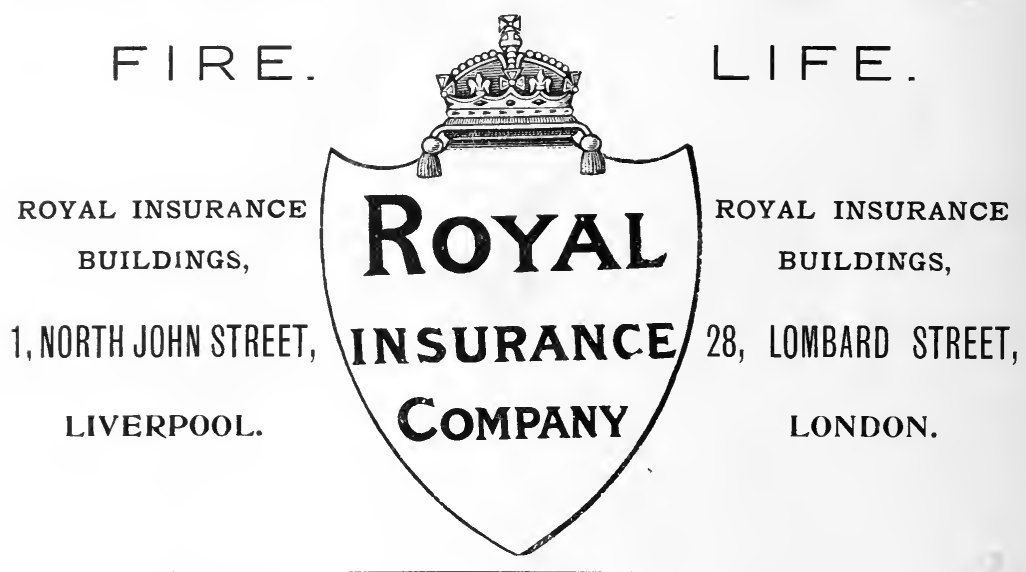

\section{Total Funds over $\mathfrak{E} 12,000,000$.}

\section{FIRE DEPARTMENT.}

Insurances of every äescription effected at moderate rates of premium. Claims promptly and equitably settled. Risks inspected and rates quoted free of charge, and every assistance rendered in arranging and revising insurances.

\section{LIFE DEPARTMENT.}

Large participation in profits. Independent valuations hy the most stringent tables. Pirofits divided every five years. Last Reversionary Bonus declared, £7 10s. per cent. Large intermediate bonuses and liberal surrender values. New non-forfeiture conditions. Low ratio of expenditure. Special facilities for meeting Death Duties; immediate payment to the Crown without probate.

ABSOLUTE SECURITY. MODERATE RATES OF PREMIUM. LIBERAL POLICY CONDITIONS.

Proposal forms and evry information may be obtained of the Head Offices, Branches, and munerous Ager:cies of the Company.

\section{Manager CHARLES ALCOCK,}

Sub-Manager-GEO. CHAPPELL. Asst. Secretaries-WM. ROPER; J. J. ATKINSON. Secretary in Lomdon-JOHN H. CROFT. 


\title{
ALLIANGE ASSURANGE COMPANY,LIMITED,
}

\author{
The Imperial Insurance Company, Limited. \\ ESTABLISHED 1824.
}

\section{Head Office:--BARTHOLOMEW LANE, LONDON, E.C.}

\section{Authorized Capital- $£ 5,250,000$ Sterling. $\quad £ 10,000,000$ Sterling.}

DIRECTORS

Chairman-The Right Hon. Lord Rorнscmus, G.C.V.O.

Charles Edward Barnett, Esq.

Right Hon. Lord BatTensea.

Frederick Cavendish Bentinck, Esq.

Francis A. Bevan, Esq.

Percivat Bosanquet, Esq.

Hon. Kenela Pleydeli Bovverie.

T. H. Burroughes, Esq.

Francis William Buxton, Eisq.

John Cator, EsQ.

Victor C. W. CaVendish, Esq., M.P.

Colonel the Hon. Everard C. DigBY.

Major-Gen. Sir Arthur Ellis, G.C.V.O., C.S.I.
James Fletcilin, Fisf.

Johis Hamptox Halk, Eisq.

Alex. I AWHIR, Esq.

Fraxicis Alrked Litcas, Fsq., M.l'。

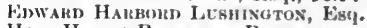

Hon. Hevir Benkkley Pontras.

Hon. LIONFi Walte Rothschili, M.P.

Hivi Colix SMти, Esq.

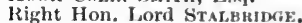

Lient.-Col. F. Axinksos Steвн1ха.

Right Hon. The Eanl of Vertilas.

sir Charless Rivens Wilson, G.C.M.G. C.B.

Robert Lewis, Gensal Manager.

\section{Liverpool Branch:-30, EXCHANGE STREET EAST.}

FREDERIC NORTH, Esq., Chairman, MORRI' P. JONES, Esq., J.P., Deputy-Chairmun.

ALFRED TYRER, Esq. FREDK. W. FRODSHAM, Esq. R. L. GREENSHIELDS, Esq.
R. ALFRED HAMPSON, Esr!

WM. BARTLETT ESg.

FRANCIS J. WELD, Ess.

GEORGE DAVISON, Esq.
H. T. OWEN LEGGATT, Secretary.
WV. F. C. HUTTON, Fire superintendent.

Branch Establishments also at Birmingham, Bristol, Bury St. Edmunds, Ipswich, Leeds, Leicester, Liverpool, Manchester, Newcastie $=0$ =Tyne, Nottingham, Sheffield, Shrewsbury, Wrexham, Edinburgh, Glasgow, Dubiln and Belfast,

\section{LIFE DEPARTMENT.}

Moderate Rates of Premium.

Large Bonuses, including Interim Bonuses.

Unclaimed Surrender Values applicd in kecping Assurances in force.

Claims paid immediately after proof of death, itge, and title.

Except in special cases, New Policies are Whole-World and Indisptitable.

DEATH DUTIES. - In order to enable the owners of P'roperty to provide for the payment of the ESTATE DUTY, Special forms of Policies have been prepared under which the Policy moneys (or such portion thereof as may be required for the purpose) will be paid direct to the Inland Revenue Office without waiting for the production of Probate. A Prospectus containing fall particnlars will be forwarded on application.

\section{FIRE DEPARTMENT.}

Fire Insurances Granted at Current Rates.

\section{LEASEHOLD AND SINKING FUND POLICIES.}

are granted (on terms which may be ascertained on application), enibling Leaseholders to recoup their expenditure by a small Ammual Prenimm, or by a single Payment in advance.

The Directors are open to entertain applications for Agencies from parties who are in a position to introduce business of a high class.

Full Prospectuses and Statements of Accounts may be had on application to the Head Office of the Company, or to Liverpool Branch, 30, Exchange Street East. 


\section{LIVERP00L LIGHTERAGE Co.,}

\section{LIMITED,}

Drury Buildings, Water Street,
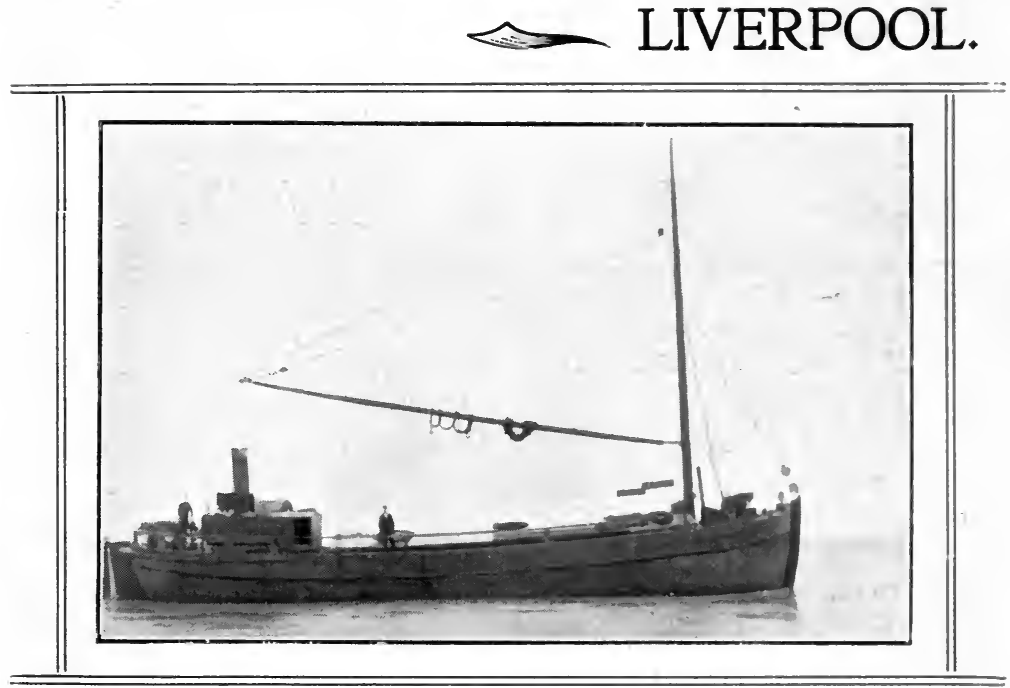

Every Description of Lighterage *** $* *$

... UNDERTAKEN BETWEEN . .

HIGH LEVEL LIVERPOOL DOCKS, BIRKENHEAD TIPS, GARSTON, WIDNES, ST. HELENS, WESTON POINT, SALTPORT, ELLESMERE PORT, NORTHWICH, MANCHESTER.

\section{Steam and Sailing Flats to all usual Coastwise Ports.}




\section{WATSON PRICKARD,}

(Combining the business of J. H. KNIGHT \& CO.),

\section{SHIRT TAILOR,}

\section{GentLemen's COMPLETE OUTFITTER,}

16. NORTH JOHN STREET,

\section{LIVERPOOL.}

Telephone- 5808 .

Telegrams-"Burnaby."

\section{BURNABY \& CHANTRELL,}

ESTABLISHED 1875.

LIVERPOOL.

-4) Lubricating Oils and Greases.

CYLINDER.

ENGINE.

SPINDLE.

\section{LOOM.}

GAS ENGINE.

DYNAMO.
MOTOR.

LAMP.

SOLIDIFIED OILS.
GREASES.

COTTON WASTE.

PACKING, ETC.

Price Lists and Samples on Application.

\section{JOHNSON \& SILVER, DUKE'S DOCK, LIVERPOOL.}

Best prices given for Californian Lining Boards. Dunnage Wood supplied at fair rates.

Telephone 5833.

\section{COCHRANE \& SONS,}

SHIPBUILDERS AND ENGINEERS, * * SELBY, Yorks.

Builders of Steam and Sailing Passenger and Cargo Vessels,

Steam Trawlers (a speciality), Steam Herring Drifters, Steam Tugs, Barges, \&C., \&c. 
$t_{120}^{0}$ 
$-$ - 
PLEASE DO NOT REMOVE

CARDS OR SLIPS FROM THIS POCKET

UNIVERSITY OF TORONTO LIBRARY 
